UNIVERSIDADE DE SÃO PAULO

FACULDADE DE ADMINISTRAÇÃO, ECONOMIA E CONTABILIDADE

DEPARTAMENTO DE ECONOMIA

PROGRAMA DE PÓS-GRADUAÇÃO EM ECONOMIA

\title{
Voting Technology and Political Competition: Lessons from overlapping political races in Brazil
}

Murilo Ferreira de Moraes

Orientador: Prof. Dr. Marcos de Almeida Rangel

OUTUBRO 2012

São Paulo 
Prof. Dr. João Grandino Rodas Reitor da Universidade de São Paulo

Prof. Dr. Reinaldo Guerreiro

Diretor da Faculdade de Economia, Administração e Contabilidade

Prof. ${ }^{a}$ Dra. Elizabeth Maria Mercier Querido Farina

Chefe do Departamento de Economia

Prof. Dr. Pedro Garcia Duarte

Coordenador do Programa de Pós-Graduação em Economia 
MURILO FERREIRA DE MORAES

\title{
Voting Technology and Political Competition: Lessons from overlapping political races in Brazil
}

\author{
Dissertação apresentada ao Depar- \\ tamento de Economia da Facul- \\ dade de Economia, Administração \\ e Contabilidade da Universidade de \\ São Paulo como requisito para a ob- \\ tenção do título de Mestre em Ciên- \\ cias.
}

Orientador: Prof. Dr. Marcos de Almeida Rangel

\author{
Versão Original \\ OUTUBRO 2012 \\ São Paulo
}




\section{FICHA CATALOGRÁFICA}

Elaborada pela Seção de Processamento Técnico do SBD/FEA/USP

Moraes, Murilo Ferreira de

Voting technology and political competition: lessons from overlapping political races in Brazil / Murilo Ferreira de Moraes. - São Paulo, 2012.

$143 \mathrm{p}$.

Dissertação (Mestrado) - Universidade de São Paulo, 2012.

Orientador: Marcos de Almeida Rangel.

1. Econometria 2. Voto eletrônico 3. Comportamento eleitoral I. Universidade de São Paulo. Faculdade de Economia, Administração e Contabilidade II. Título.

CDD -330.015195 
À minha família e à Anna Olimpia 


\section{AGRADECIMENTOS}

Incidem nessa página as referências mais relevantes e, como em grande parte das dissertações, a menor quantidade de tempo dispensado (as poucas horas que antecedem a impressão). Dada a infinidade de agradecimentos, começo por reconhecer que qualquer omissão é meramente fruto de uma memória limitada e respeito ao limite de caracteres. Agradeço em primeiro lugar ao corpo docente do IPE-USP pelo ensino de excelência proporcionado tanto durante a graduação quanto durante o mestrado acadêmico. Ao meu orientador Marcos Rangel, que me deu diretrizes e conhecimentos para a definição e elaboração desse trabalho, agradeço a orientação detalhista. Registro aqui o meu muito obrigado pela paciência e pelas inúmeras e frutíferas sugestões.

Essa dissertação teve participação direta de diversos amigos. Daniel Tanis e Lucas Mation, obrigado pela paciência e pelo auxílio. Em especial agradeço a ajuda do Heitor Pellegrina; uma alusão à figura de co-orientador é sugestiva da importância que teve para esse trabalho.

Aos colegas do mestrado, nos quais incluo tanto a turma de 2010 quanto os veteranos, agradeço pela convivência intensa durante toda a trajetória. Foram fundamentais as longas discussões na salinha de café e a colaboração durante os momentos mais críticos dos estudos. Agradeço em especial ao André Mendes, Danilo Passos, Eduardo Sanchez, João Bastos, Lia Chitolina, Paula Kasmirski, Sarah Bretones e Victor Westrupp. Destaco a amizade do João Improta que excede o período e a convivência no mestrado.

Agradeço aos amigos que fiz ao longo da graduação e no período posterior a ela. Obrigado por não desistirem mesmo quando a ausência devido aos estudos foi excessiva. Seria infrutífera a tentativa de citá-los nominalmente e por isso me limito a dizer que, embora raros, os encontro com eles durante a trajetória foram essenciais para tornar essa passagem pelo mestrado mais agradável. Agradeço também aos companheiros de Brasília e ao Fernando Kawaoka pela ajuda no mestrado e com a revisão e pela amizade na capital.

Muito obrigado à minha família, cujo apoio incondicional desde muito antes do mestrado sempre serviu de porto seguro para os momentos de indecisão e inquietação. Agradeço à minha mãe, Eduarda, meu pai, José Augusto, e às minhas irmãs, Camila e Melina, pelo suporte e motivação durante esses anos de estudos.

Finalmente, mas não menos importante, agradeço à minha namorada, Anna Olimpia. Companheira inseparável de diversas jornadas, se inclui em todos os grupos acima: revisora da dissertação, colega de estudos, amiga de faculdade e em Brasília. Sua alegria e motivação são força motriz para meu caminhar e seu companheirismo é peça fundamental para todas as empreitadas.

Por último, agradeço à $\mathrm{CNPq}$, pelo apoio financeiro. 
"Scientists often gain insight into a more complex problem by thinking through a simpler toy problem". Stuart Kauffman 


\section{RESUMO}

Essa dissertação consiste em uma análise das mudanças em resultados eleitorais associadas a adoção do voto eletrônico em 1998. Utiliza-se para essa investigação, a análise empírica de resultados das eleições para diferentes cargos entre 1994 e 2002. A partir da descontinuidade associada à adoção do voto eletrônico em 1998, em substituição à cédula de votação, e da estrutura sazonal das eleições brasileira (que, com um intervalo de dois anos, alterna as eleições municipais e as estaduais/federais) exploramos o impacto eleitoral da adoção da nova tecnologia e os desdobramentos em outras variáveis políticas. Encontramos forte evidência de que o voto eletrônico resultou em enfranchising (aumento dos votos válidos) e, em última instância, em maior nível de competição política. Usamos a mudança no grau de competição como fonte para identificação dos determinantes da alocação de gastos municipais. Especificamente, encontramos evidências que sugerem que aumentos no nível de competição política, para municípios com níveis menos acirrados de disputada eleitoral, tem impacto na realocação dos orçamento público municipal em direção aos gastos com saúde. 


\begin{abstract}
This dissertation investigates changes in election results associated with adoption of different voting technologies. The empirical application uses election data for different offices from the period 1994-2002. We exploit a discontinuity associated with a change of the voting mechanism, from paper ballot to Direct Recording Electronic (DRE), conditioned on Brazilian election structure with overlap (local elections held two years out of phase with general elections) as a source of identification for election results determinants. We find robust evidence that the shift to an easier voting mechanism reflected on an enfranchising effect (increase in valid votes) which ultimately resulted in more political competitiveness. The impact on election outcome creates a source of identification for the determinants of mayors decision related to municipalities' resource allocation. Specifically, we find evidence suggesting that facing an increase in political competition municipalities with a previous low level of competition reallocate public spending towards health care.
\end{abstract}




\section{Summary}

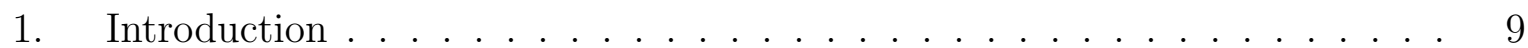

2. Institutional background and the electronic voting technology . . . . . . . 13

2.1 Voting Mechanisms . . . . . . . . . . . . . . 15

3. Outcomes derived from electronic voting technology introduction . . . . . . 21

4. Methodology and Data Structure . . . . . . . . . . . . . 25

4.1 Voting technology affecting election results . . . . . . . . . . 25

4.2 Blank and spoiled votes . . . . . . . . . . . . . . . 30

4.3 Political Competition . . . . . . . . . . . . . . . . . . . . 31

4.4 Paper Ballot Impact . . . . . . . . . . . . . . . . . . . 35

4.5 Mayor expenditure . . . . . . . . . . . . . . 36

$4.6 \quad$ Robustness Check . . . . . . . . . . . . . . . . . . 38

5. Results ......................... . . 41

5.1 Invalid votes . . . . . . . . . . . . . . . . . . 41

5.2 Political Competition . . . . . . . . . . . . . . 47

5.2.1 Party Code Votes and Fractionalization . . . . . . . . 47

5.2.2 Candidates and Party performance . . . . . . . . . . 50

$5.3 \quad$ Paper Ballot Impact . . . . . . . . . . . . . . . . . . . . . . . 52

5.4 Political Competition and resource allocation . . . . . . . . . . 55

6. Conclusion . . . . . . . . . . . . . . . . . . . . . 57

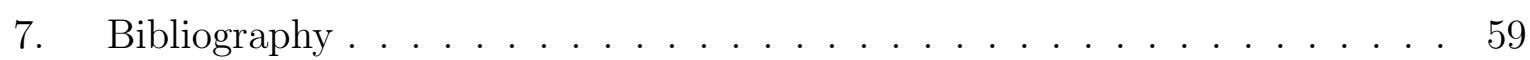

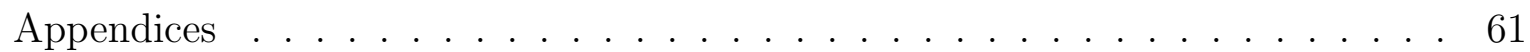




\section{List of Tables}

1 Valid and invalid votes . . . . . . . . . . . . . . . . . 21

2 Candidate and party code vote . . . . . . . . . . . . . 23

3 Paper ballot order and 1998 President Election Results . . . . . . . . . 35

4 Paper ballot order and 1994 President Election Results . . . . . . . . . 36

5 Electronic voting impact on Invalid Votes . . . . . . . . . . . . . . 42

6 Electronic voting impact on Blank Votes . . . . . . . . . . . . . . . 44

7 Electronic voting impact on Spoiled Votes . . . . . . . . . . . . . 45

8 Electronic voting impact on Party Votes . . . . . . . . . . . . 48

9 Electronic voting impact on Party Fractionalization . . . . . . . . . . . . . 49

10 Paper Ballot impact on bookend candidates . . . . . . . . . . 53

11 Electronic voting impact on the "first" vote . . . . . . . . . . . . . 54

12 Electronic voting impact on municpality resource allocation (99 vs 98 - IBGE) 56

13 Socioeconomic Characteristics . . . . . . . . . . . . . . . . . 62

14 Share (\%) of each item on municipality budget (1999) . . . . . . . . . 62

$15 \quad 1994 / 1998$ Election data . . . . . . . . . . . . . . . . . . 63

16 Electronic voting impact on Turnout . . . . . . . . . . . . . . . . 66

17 Electronic voting impact on Candidate Fractionalization . . . . . . . . 67

18 Electronic voting impact on Best Loser Votes . . . . . . . . . . . . . . 67

19 Electronic voting impact on Best Loser Votes (State Deputy Only) . . . . 68

20 Electronic voting impact on PT party code votes (over total party code votes) 68

21 Electronic voting impact on PSDB Votes party code votes (over total party code votes $) \ldots \ldots \ldots \ldots$. . . . . . . . . . . . . . . 69

22 Electronic voting impact on PMDB Votes party code votes (over total party

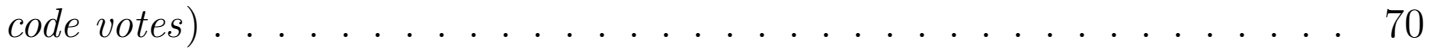

23 Electronic voting impact on PFL Votes party code votes (over total party code votes $\ldots \ldots \ldots \ldots \ldots \ldots$. . . . . . . . . . . . 71

24 Electronic voting impact on Votes for the Mayor Party . . . . . . . . . . 72

25 Electronic voting impact on Party Code Votes from the Mayor Party (over total party code votes $\ldots \ldots \ldots \ldots$. . . . . . . . . . . 73

26 Electronic voting impact on the probability of choosing the same party for legislative and president offices . . . . . . . . . . . . . 74

27 Electronic voting impact on the probability of choosing the same party for legislative offices (party code votes) _ . . . . . . . . . . . 75

28 Electronic voting impact on the odds of voting for PSDB deputy over PSDB

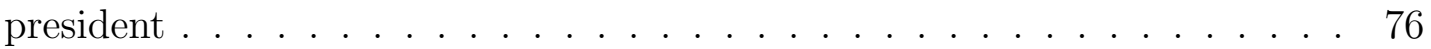


29 Electronic voting impact on the odds of voting for PSDB deputy (Party Code) over PSDB president . . . . . . . . . . . . . . . . . 77

30 Electronic voting impact on the odds of voting for PT deputy over PT president . . . . . . . . . . . . . . . . . 78

31 Electronic voting impact on the odds of voting for PT deputy (Party Code) over PT president . . . . . . . . . . . . . . . . . . . . 79

32 Paper Ballot impact on bookend candidates (around discontinuity threshold $\pm 20,000) \ldots \ldots \ldots \ldots$. . . . . . . . . . . . 80

33 Paper Ballot impact on bookend candidates - 1994 . . . . . . . . . . . . 80

34 Paper Ballot impact on bookend candidates (around discontinuity threshold $\pm 20,000-1994) \ldots \ldots \ldots$. . . . . . . . . . . . 81

35 Electronic voting impact on municpality resource allocation (99 vs 98 - IBGE) 81

36 Electronic voting impact on municpality resource allocation (99 vs 98 - IBGE) 82

37 Electronic voting impact on municpality revenues (99 vs 98 - IBGE) . . . . 83

38 Electronic voting impact on municpality resource allocation (99 vs 97 FINBRA) . . . . . . . . . . . . . . . . . . . 84

39 Electronic voting impact on municpality resource allocation (99 vs 97 FINBRA) . . . . . . . . . . . . . . . . . 84

40 Electronic voting impact on municpality resource allocation (99 vs 97 FINBRA) . . . . . . . . . . . . . . . . 85

41 Discontinuity - Electronic voting impact on Invalid Votes . . . . . . . . . . 86

42 Discontinuity - Electronic voting impact on Blank Votes . . . . . . . . . . 87

43 Discontinuity - Electronic voting impact on Spoiled Votes . . . . . . . . . . 88

44 Discontinuity - Electronic voting impact on Turnout . . . . . . . . . . . . . 89

45 Discontinuity - Electronic voting impact on Party Votes . . . . . . . . . . . 90

46 Discontinuity - Electronic voting impact on Party Fractionalization . . . . 91

47 Discontinuity - Electronic voting impact on Candidate Fractionalization . . 92

48 Discontinuity - Electronic voting impact on Best Loser Votes (State Deputy

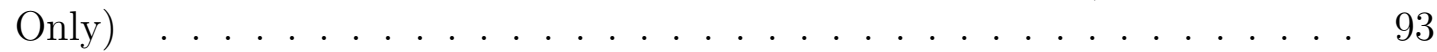

49 Discontinuity - Electronic voting impact on Invalid Votes (Considering vote

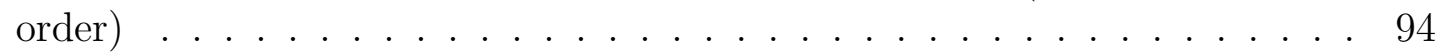

50 Discontinuity - Electronic voting impact on PT party code votes (over total

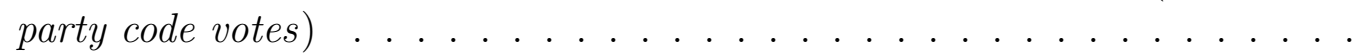

51 Discontinuity - Electronic voting impact on PSDB Votes party code votes (over total party code votes) . . . . . . . . . . . . . . . . . 96

52 Discontinuity - Electronic voting impact on PMDB Votes party code votes (over total party code votes) . . . . . . . . . . . . . . . . . . . . . 97

53 Discontinuity - Electronic voting impact on PFL Votes party code votes (over total party code votes) . . . . . . . . . . . . . . . . . . . . . 98

54 Discontinuity - Electronic voting impact on Votes for the Mayor Party . . . 99 
55 Discontinuity - Electronic voting impact on Party Code Votes from the Mayor Party (over total party code votes) . . . . . . . . . . . . . . . 100

56 Discontinuity - Electronic voting impact on the probability of choosing the same party for legislative and president offices . . . . . . . . . . . . . 101

57 Discontinuity - Electronic voting impact on the probability of choosing the same party for legislative offices (party code votes) . . . . . . . . . . . 102

58 Discontinuity - Electronic voting impact on the odds of voting for PSDB deputy over PSDB president . . . . . . . . . . . . . 103

59 Discontinuity - Electronic voting impact on the odds of voting for PSDB deputy (Party Code) over PSDB president . . . . . . . . . . . . . 104

60 Discontinuity - Electronic voting impact on the odds of voting for PT deputy over PT president . . . . . . . . . . . . . . . 105

61 Discontinuity - Electronic voting impact on the odds of voting for PT deputy (Party Code) over PT president . . . . . . . . . . . 106

62 Tight election race - Electronic voting impact on Invalid Votes . . . . . . . 107

63 Tight election race - Electronic voting impact on Blank Votes . . . . . . . 108

64 Tight election race - Electronic voting impact on Spoiled Votes . . . . . . . 109

65 Tight election race - Electronic voting impact on Turnout . . . . . . . . . . 110

66 Tight election race - Electronic voting impact on Party Votes . . . . . . . . 111

67 Tight election race - Electronic voting impact on Party Fractionalization . 112

68 Tight election race - Electronic voting impact on Candidate Fractionalization 113

69 Tight election race - Electronic voting impact on the "first" vote . . . . . . 114

70 Tight election race - Electronic voting impact on PT party code votes (over total party code votes $)$. . . . . . . . . . . . . . . . . . . . . 115

71 Tight election race - Electronic voting impact on PSDB Votes party code votes (over total party code votes) . . . . . . . . . . . . . . . 116

72 Tight election race - Electronic voting impact on PMDB Votes party code votes (over total party code votes) . . . . . . . . . . . . . . . . . 117

73 Tight election race - Electronic voting impact on PFL Votes party code votes (over total party code votes) . . . . . . . . . . . . . . . . . 118

74 Tight election race - Electronic voting impact on Votes for the Mayor Party 119

75 Tight election race - Electronic voting impact on Party Code Votes from the Mayor Party (over total party code votes) . . . . . . . . . . . . . 120

76 Tight election race - Electronic voting impact on the probability of choosing the same party for legislative and president offices . . . . . . . . . . . . 121

77 Tight election race - Electronic voting impact on the probability of choosing the same party for legislative offices (party code votes) . . . . . . . . . 122

78 Tight election race - Electronic voting impact on the odds of voting for PSDB deputy over PSDB president . . . . . . . . . . . . . . . . 123

79 Tight election race - Electronic voting impact on the odds of voting for PSDB deputy (Party Code) over PSDB president . . . . . . . . . . . . . . 124 
80 Tight election race - Electronic voting impact on the odds of voting for PT deputy over PT president . . . . . . . . . . . . . . . . . 125

81 Tight election race - Electronic voting impact on the odds of voting for PT deputy (Party Code) over PT president . . . . . . . . . . . . . . 126

82 Placebo (2002) - Electronic voting impact on Invalid Votes . . . . . . . . . 127

83 Placebo (2002) - Electronic voting impact on Blank Votes . . . . . . . . . . 128

84 Placebo (2002) - Electronic voting impact on Spoiled Votes . . . . . . . . . 129

85 Placebo (2002) - Electronic voting impact on Turnout . . . . . . . . . . . 130

86 Placebo (2002) - Electronic voting impact on Party Votes . . . . . . . . . . 131

87 Placebo (2002) - Electronic voting impact on Party Fractionalization . . . 132

88 Placebo (2002) - Electronic voting impact on Candidate Fractionalization . 133

89 Placebo (2002) - Electronic voting impact on the "first" vote . . . . . . . . 133

90 Placebo (2002) - Electronic voting impact on Party Code Votes from the Mayor Party (over total party code votes) . . . . . . . . . . . . . . 134 


\section{List of Figures}

1 Historic invalid votes in Federal Deputy elections . . . . . . . . . . . . 16

2 Historic invalid votes in State Deputy elections . . . . . . . . . . . . . 16

3 Paper ballot for 1994 election $\left(1^{\text {st }}\right.$ round $) \ldots \ldots \ldots \ldots$. . . . . . . 17

$4 \quad$ Chronology: electronic voting in Brazil . . . . . . . . . . . . . . . . . 18

5 Invalid votes (blank plus spoiled) for State deputy election . . . . . . . . . 21

6 Invalid votes (blank plus spoiled) for Federal deputy election . . . . . . . . 22

$7 \quad$ Blank Votes behavior . . . . . . . . . . . . . . . . . . . . . 27

8 Spoiled Votes behavior . . . . . . . . . . . . . . . . . 28

9 Covariates behavior $(1) \ldots \ldots \ldots \ldots \ldots$

10 Covariates behavior $(2) \ldots \ldots \ldots \ldots \ldots \ldots$

11 Covariates behavior $(3) \ldots \ldots \ldots \ldots \ldots$

12 Number of parties disputing each office in each State . . . . . . . . . . . 32

13 Blank Votes (black dots = electronic voting / left=1994; right=1998) . . . 43

14 Spoiled Votes (black dots = electronic voting / left=1994; right=1998) . . . 43

15 Summary - Electronic voting impact on invalid votes $(P$ - president; $G$ governor; F - Federal deputy; S - State deputy) . . . . . . . . . . 46 


\section{Introduction}

Recent employment of different voting mechanisms combined with a handful of controversial election results and specific voting patterns that emerge from elections have motivated a broad dialogue about the potentially decisive effects of alternative voting technologies. For instance, Dee (2007) identifies how different voting mechanisms affects voting mistakes in California's gubernatorial recall election, presenting evidence that: i) the position of candidates in the ballot affect the number of votes mistakenly attributed to them; ii) different voting technologies have distinct impact on the errors. ${ }^{1}$ Ansolabehere e Stewart III (2005), alternatively, analyze the relative performance of voting technologies in the United States employing a broad panel containing counties' electoral results for presidential, gubernatorial, and senatorial election. They find that uncounted votes rates depends dramatically on the voting technology used: about 500,000 votes would have been attributed to presidential candidates nationwide in 2000 election if the best technologies were adopted.

Despite the widely discussed characteristics of voting mechanisms, such as voting accountability and fraud propensity, the confidentiality of elections and the sanctity of the secret of individual vote, essential prerequisite of any free election, makes it harder to measure how the choice among voting mechanisms might impact election outcomes. ${ }^{2}$ Herrnson et al. (2005) analyses the impact of electronic voting adoption in U.S. 2000 presidential election and concluded that the new mechanism, associated with education campaigns previous to the election, had a positive feedback among voters. However, voters' trust in the system is not guaranteed per se as voters may have difficulty in using the machines and there is no certain of an accurately recorded vote (unless the machine prints a record of the ballot that was electronically recorded). But besides specifics analysis, all of these studies share a common perception that understanding how voting mechanisms affect election results reveals us a great deal about voters behavior and might shed light on political outcome determinants.

In another matter, an important object of investigation for political economy is the effect of political competition on fiscal policy, considering both the level of government spending and its composition. Besley et al. (2010) develops a simple model linking lack of political competition to lower economic growth. Using a panel data for the US States the authors

\footnotetext{
${ }^{1}$ See Alvarez et al. (2001) for a wider discussion about the 2000 Florida recounts.

${ }^{2}$ Card e Moretti (2007) investigates whether the use of electronic voting is associated with election results frauds as argued by critics. Though finding no association between voting irregularities and adoption of touch-screen voting, their investigation suggests a negative impact of the adopted technology on estimated turnout rates.
} 
find robust evidence that lack of political competition is associated with anti-growth policies (higher taxes, lower capital spending and a reduced likelihood of using right-to-work laws). Reingewertz (2009) examines how the level of competition affects public accounts using cross-section and panel analysis of Israeli municipalities financial and political variables. The results suggest that an increase in political competition, when it is already high, is usually associated with larger debts.

This dissertation innovates by using a shift in Brazilian voting process from paper voting to Direct Recording Electronic (DRE) voting system, associated with a population discontinuity, to investigate the relation between political competition and political outcome. More specifically, we use this quasi-experimental to emphasize the importance of political enfranchising on election results and competition and how an increase in the number of effective electors (i.e., with valid counted votes) affects resource allocation in municipalities. We rely on the fact that the new technology reduced the likelihood of voting mistakes, since the difficult inherent to the filling process of paper ballot represented an obstacle for a significant percentage of the electors willing to express their political preferences. By making the voting process easier, the DRE allows us to use the enfranchising effect in order to identify several effects of election results on politics.

Combining this historical event with the specific Brazilian election structure, which alternates every two years the Federal and State elections with the municipal ones, we investigate how the new voting mechanisms affected a set of political results. From the impact on residual votes to specific parties performance in major elections, we investigate how this might be related to municipalities political characteristics, as mayors and parties visualize the results of the Federal election as an anticipated local poll. In other words, major elections are interpreted as midterm polls and a measure of local political strength, affecting policy decision during the following years. The discontinuity associated with the adoption of electronic voting provides a unique opportunity to investigate this relation in Brazilian politics as it provides a reliable control (paper ballot) and a treatment groups (electronic voting). Recent results from Fujiwara (2010) demonstrates that electronic voting in Brazil reduced residual, generating the aforementioned enfranchisement effect (arguing that the increase of valid votes is strictly related with less educated voters). Results suggest that the increase of political participation of less educated voters results in a shift on State-level public spending towards health care.

This dissertation provides a broad discussion about the introduction of electronic voting in Brazil and how it affected election results and political competition. We provide strong evidence that the new mechanism resulted in a heterogeneous political enfranchi- 
sing (distinguishing the effect on the type of vote invalidation - blank or spoiled), related to municipalities characteristics, and the enhance of valid resulted in increase of political competition. We also investigate how the "new" mechanism affected major parties' performance. Finally, we investigate if the increase in competition affected municipality budget reallocation. We find evidence suggesting that, in municipalities with previous low level of political competition, the introduction of electronic voting (and thus an increase in competition) resulted in municipal-level budget reallocation towards health spending.

The rest of the work is organized as follows. In section 2, we describe the institutional background, in what concerns both the political/election structure (elections with overlap) and the voting mechanism. In section 3 we discuss our data and the methodology used, exploring in detail our measures of political competition and how the shift in the voting mechanism creates an identification strategy for the link between competition and political outcome. Section 4 presents and discuss our main findings, and Section 5 concludes. 


\section{Institutional background and the electronic voting technology}

Brazil is a large representative democratic system, composed of 26 States, a Federal district and more than 5,000 municipalities. Since 1990, elections are held every four years to elect executive and legislative offices at the Federal and State level. The electoral date and rules are the same across municipalities and determined by a Federal institution called Superior Electoral Court. The set of elective positions are: president and vicepresident, governor and vice-governor (1 each, for each of the 26 States and for the Federal District), senator (81, each State and the Federal district electing 3), Federal deputy (a total of 513, distributed according to each State population, respecting a minimum of 8 Federal deputies and a maximum of 70 per State), State deputy (1,059 total, distributed respecting a relation with the number of the Federal deputy of each State), mayor and vice mayor (approximately 5,500, one for each city) and city council member (proportional to the municipality population, being almost 60,000$){ }^{3}$

The elections for the legislative offices (State deputy, Federal deputy and city council member) are different from the executive ones in terms of seat distribution: first, the number of valid votes is divided by the number of seats, which creates a votes per seat measure (hare quota). After that, the measure of votes that each party received (either as a candidate vote or as a party vote) is divided by this number, being the integer part of this division called the party quota and, ultimately, the number of seats that the party will receive. ${ }^{4}$ In case there are leftovers, the seats are distributed according the average vote per seat that each party received (see B for further details). This process is iterated until all the seats are filled with one candidate. Within each party, the seats were allocated respecting the rank defined by the election for the party's candidates. This means that the political parties do not rank-order their candidates, respecting the order defined by voters' preference. As posed by Power e Roberts (1995), this structure weakens party authority over politicians.

The present Brazilian election system was mainly established after the military regime with the publication of the 1988 Constitution. A republican platform was chosen with a

\footnotetext{
${ }^{3}$ As defined by the Federal Constitution, article 27, the number of State deputies will be the triple of the number of the Federal deputies, up to 36 State deputies. For States with more than 12 Federal deputies, the number of State deputies will be 36 plus the difference of this total and 12. Being $n_{s}^{F}$ the number of Federal deputies of State $s$, the number of State deputies, $n_{s}^{S}$, will be given by the following formula:

$$
n_{s}^{S}=1 \Perp\left\{n_{s}^{F} \leq 12\right\} \times\left(n_{s}^{F} \times 3\right)+1\left\{n_{s}^{F}>12\right\} \times\left(24+n_{s}^{F}\right)
$$

${ }^{4}$ In fact, it is considered the number of votes a coalition received. Coalition are created in each States by parties unifying their party code for the electoral campaign.
} 
presidential system of government, where president, governors and mayors of cities with more than 200 thousand electors were elected by absolute majority or in two rounds (in cities with less than 200 thousand electors, elections are decided by absolute majority). ${ }^{5,6}$ Voting is compulsory for those eligible to vote: 1988 Constitution ensured optional voting for 16 and 17-year- olds, for illiterates (whose right to vote was guaranteed by a 1985 constitutional amendment, incorporated to the 1998 text) and for persons over 70 years of age. For all citizen between 18 and 70 years old who are not declared illiterates, voting is compulsory and unjustified voting abstention results in fines and other legal penalties.

The overlap structure, ensured firstly by the 1967 Constitution was reinitiated after the Re-democratization with the 1988 elections. $^{7}$ In comparison with the 1945-1964 period (that also held regular and direct elections) when mayor's and president's elections could occur simultaneously, this structure defined an electoral cycle where parties and candidates take advantage of the connections between the different levels of government to establish political control of local electors. ${ }^{8}$ Therefore, both political participation of local politics in major elections and of deputies, governors and even president candidates in the municipal ones are characteristics omnipresent in all recent political dispute. ${ }^{9}$

This structure created two phenomena of significant importance for the political field. First, the overlap condition generates a reasonable proxy for the political performance of all incumbents in the local level. A mayor can visualize his party performance on major elections, in the city he administrates, as a midterm poll and a proxy for his approval rating. Deputies, on the other hand, can evaluate whether their political behavior towards his local electoral support are effectively affecting the voters choice (by analyzing the performance of his party's candidate or his party's coalition). Second, it a creates a political trampoline for office-seeking candidates, as they visualizes the gap between elections as opportunities for building political power (i.e., to achieve better offices politics can engage in other disputes in order to increase his interaction with electors).

As rigorously described in Samuels (2003), many of the legislative offices are not perceived as a long-term career, but rather as a path to achieve better positions in the

\footnotetext{
${ }^{5}$ The republican platform was corroborated by a plebiscite in 1993 .

${ }^{6}$ Several studies on Brazilian politics relies on this discontinuity to investigate political results. See, for example,Gonçalves et al. (2008), Mello et al. (2009) and Fujiwara (2008).

${ }^{7}$ The two years gap between the Federal and State elections and the municipality's ones was reasoned as way to protect municipal autonomy by detaching it from the major elections.

${ }^{8}$ See the entire Brazilian elections chronology in http://www.tse.jus.br/eleicoes/ eleitos-1945-1990/cronologia-das-eleicoes - only in Portuguese

${ }^{9}$ This symbiosis between levels of the government is so intense that there is even an institute, created by several labor unions, that maps, in every local election, the Federal deputies and senators that run for the city hall office.
} 
executive branch of the subnational government. As noted by a Brazilian newspaper (CABRAL; FALCÃO, 2012), 21\% of the congressmen (121 Federal deputies and 6 senators) were considering leaving their offices to run for mayor in 2012 election indicating that a legislative position represents a common path to a strong mayor candidacy. Samuels (2003) notes that not only incumbent deputies leave State level position to dispute mayor elections, but they also do it to take (important) nonelective positions in municipal, State, or national government. In a compilation made by the author, he estimated that in the 1995-98 period, $17 \%$ of the deputies left their seats for that reason, with politicians leaving their current offices to pursue municipal and State positions. ${ }^{10}$ Considering those reasons (running for other offices or leaving for nonelective positions), Samuels (2003) notes that between $35 \%$ to $40 \%$ of incumbent deputies tried to leave (or even left) the Federal Chamber, suggesting the the position of deputy is not at the top of the political career ladder in Brazil.

\subsection{Voting Mechanisms}

In addition to the country size and levels of government, the amount of political parties and candidates in Brazil makes the voting procedure a particularly complex one. Because of that, Brazilian voters have to deal with a huge number of candidate codes and, also, with their respective party codes. The choice procedure is not necessarily more difficult because of those complexities, but certainly the patterns that emerge from voting behavior may be more difficult to identify when compared with a two party system.

It is historically known that a significant part of Brazilian electors were not able to fully express their political preferences or were misrepresented by a difficulty imposed by the voting mechanism. As Figures 1-2 show, blank and spoiled votes high rates in Brazil have a long and persistent history. The explanations for the evolution and the size range from political, socioeconomic and institutional reasons (POWER; ROBERTS, 1995).

On the political side, throughout Brazilian history there were several campaigns for using the invalid votes to protest against the status quo political structure (POWER; ROBERTS, 1995; ALVES, 1985). The institutional reason lies on the fact of high rates invalid votes being a long-standing feature of compulsory voting systems as it the natural substitute to vote abstention present in system where absentee voting is allowed (HIRCZY, 1994). Third, the socioeconomic status of electors, such as poverty, participation of women in

\footnotetext{
${ }^{10}$ The attractiveness of municipal-level position increased after 1988 constitution that gave municipalities a status of Federal entities and with the spread of urbanization and industrialization which made urban centers politically more attractive.
} 


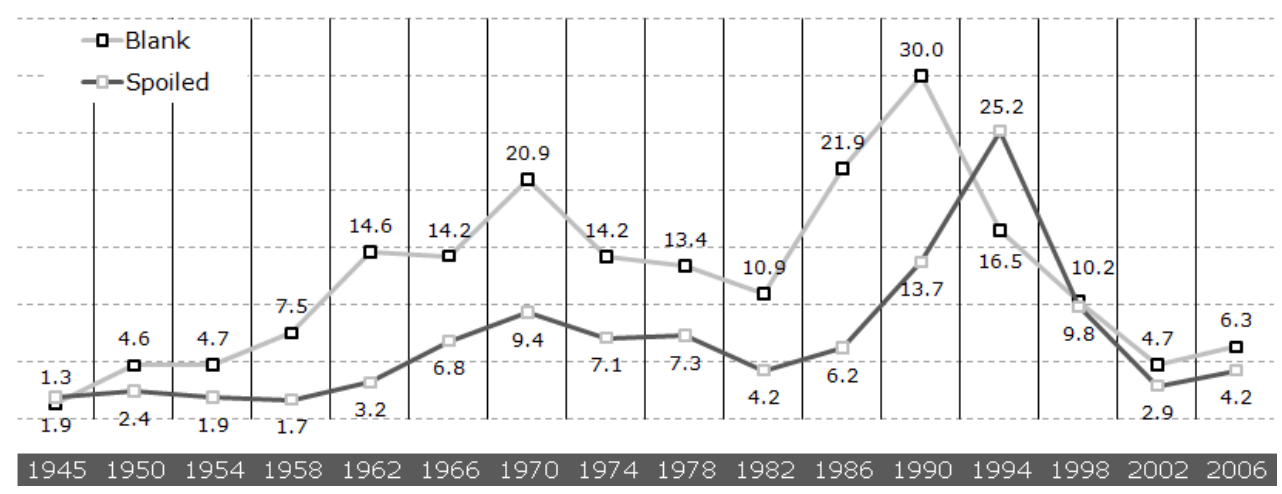

Figure 1: Historic invalid votes in Federal Deputy elections

work force, education/literacy and urbanization, seems to play an important role on the dynamics of invalid votes. Power e Roberts (1995) (and Katz, 2011) investigates the influence of those determinants in Brazilian invalid vote share and abstention rates. They find robust evidence of impact of each of these variables. However the impact is not uniform for distinct offices' elections nor are all the variables significant for elections as a whole.

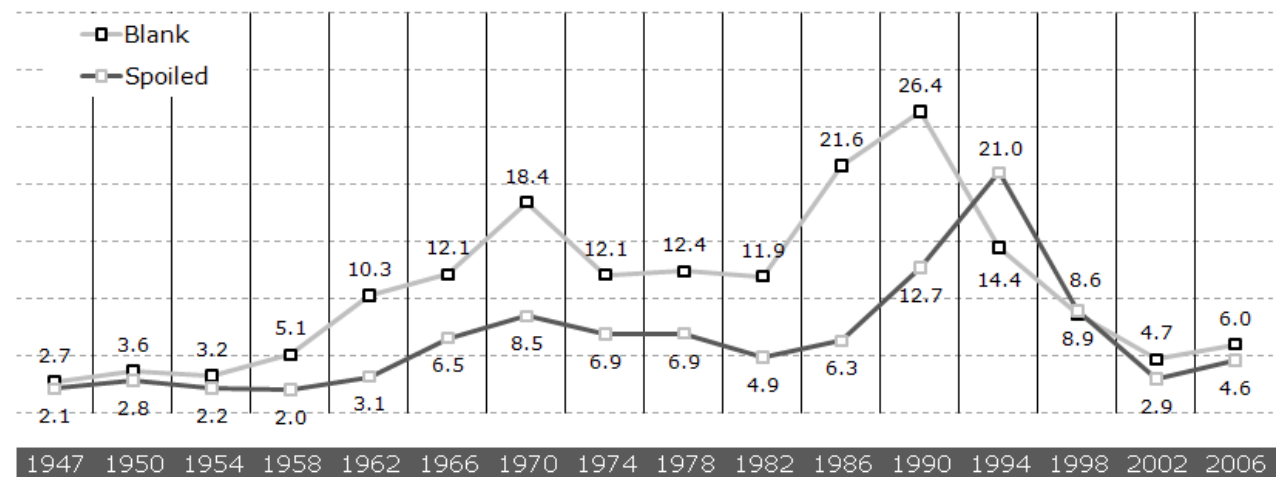

Figure 2: Historic invalid votes in State Deputy elections

We explore here the role of the voting mechanism on the patterns raised above. Until 1994's elections every municipality in Brazil used a paper ballot system (depicted in figure 3) which did not make voting registration easy and reliable. On the contrary, it created several difficulties for vote validation. For one reason, the voting process based on the paper ballot relies exclusively on the elector capacity to choose, verify and express his political preference and the way he did it differs among offices. Second, filling the paper ballot was a difficult task. For choosing a president, a State governor and a senator it was necessary for the voters to read the name of the candidates and fill a check-box; as simple as it may sounds, table 13 reveals that that was certainly not an easy task for at least $30 \%$ of Brazilian population who was illiterate. For legislative offices, voting for both 
State and Federal deputy required writing one of the following information: name of the candidate or his number or the name of the party (or its abbreviation) or its number. A poor education scenario, the municipalities socioeconomic heterogeneity and low levels of political engagement are factors that affected negatively the rate of valid votes in Brazil (see table 13).

It is important to stress out here the difference mentioned before between the executive (president, governor) and senator elections and the State and Federal deputies' ones. As we explained, the filling process for these offices is different: for the first one electors should fill a check box and for the legislative offices they should write down the choice (figure 3). Because of that, at least two characteristics that emerge from this difference are relevant to our analysis. First, the fact that the elector had to read the names of the executives and senator candidates (allowing him to use the paper ballot to "remember" his choice, if he were able to read) and that he had to write the name of his deputies. Second, he could choose between a candidate or a party when voting for deputies. Both characteristics will be important for our analysis.
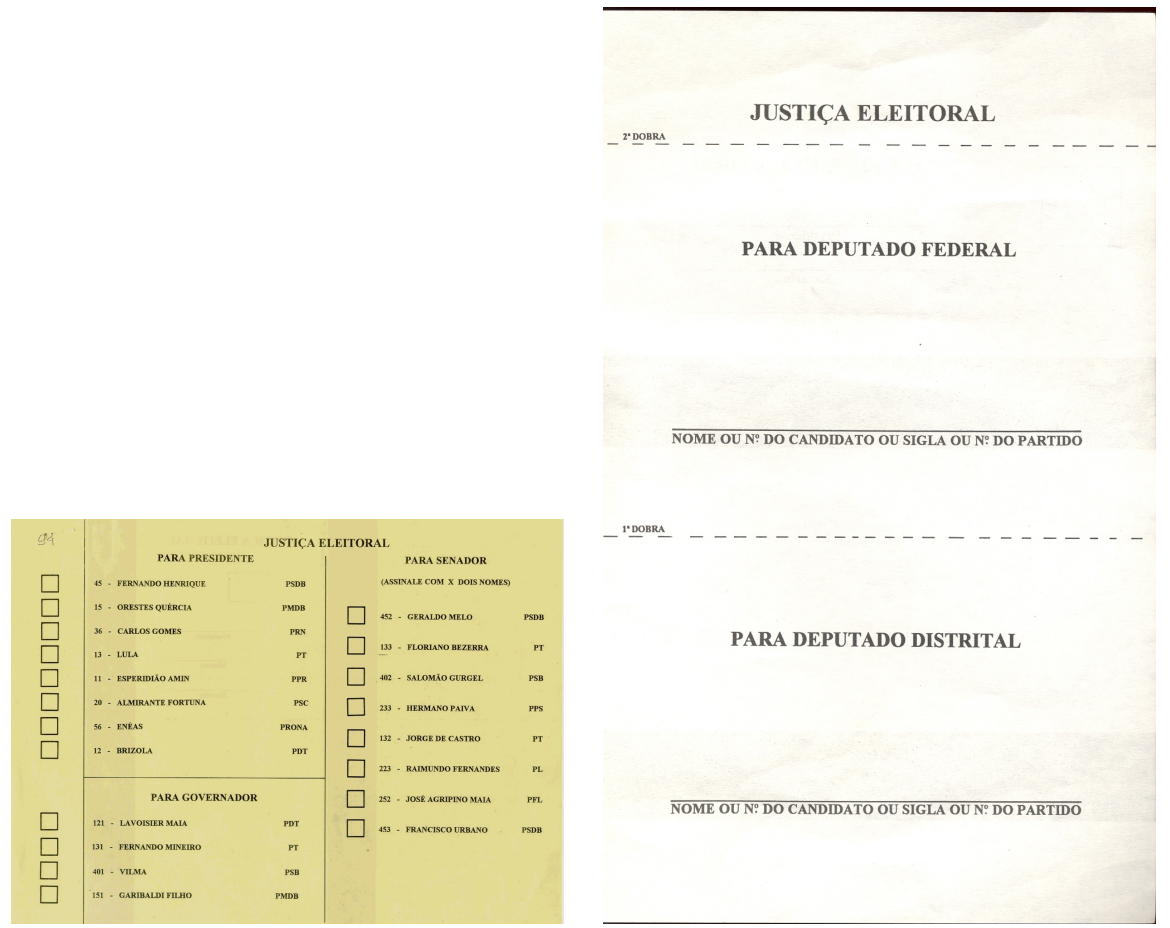

Figure 3: Paper ballot for 1994 election (1 ${ }^{\text {st }}$ round)

The paper ballot also led to a significant number of invalid votes because of the validation process. The process of vote counting and validation was at responsibility of a committee comprised by one judge and two-four members, of known trustworthiness. However, each party could choose representatives which would audit the vote count process. The 
committee could invalidate a vote based on arguments defined by the electoral code which include misspelling, double vote, paper ballot violation (such as elector identification or not filling the paper right), among others. ${ }^{11}$, Based only on the Brazilian political and socioeconomic characteristics we could already expect a large number of spoiled votes. If we also take in account the parties audition and the obvious interest of invalidating votes for other parties, this number can be even bigger.

However, in 1998 the Superior Electoral Court decided to change the voting mechanism and assigned the use of electronic machines for that year's election. Municipalities with more than 40,500 registered voters employed the new technology, while municipalities below this threshold still used the paper ballot system.$^{12}$ The use of electronic voting actually began in the 1996's elections for mayor and city council. In this occasion, only 57 cities used the electronic voting system, respecting a threshold of 200,000 registered electors. It was only in 2000 that every municipality used the electronic voting system. The image 4 bellow summarizes the chronology of the voting mechanisms used in Brazilian elections.

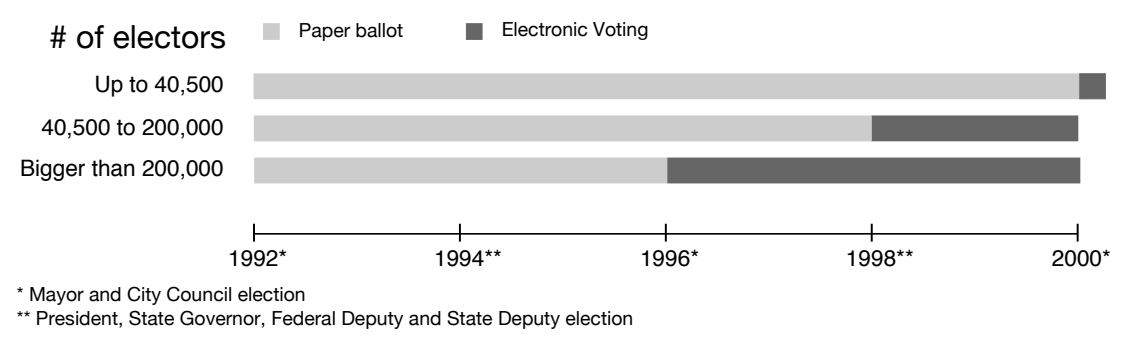

Figure 4: Chronology: electronic voting in Brazil

Different from the paper ballot system, the electronic voting allows the voter to see the face of his candidate on the screen as he enters the candidate code. By doing so, the machine provides a visual confirmation which allows the voter to check if he correctly chose the candidate. Furthermore, the machine accuses if the number entered is invalid and requires the voter to confirm his selection. Therefore, if a voter mistakenly choose a number or if he unintentionally choose a blank vote, the confirmation step gives him the chance to repair his choice.

From the elector perspective, another significant difference is that voting under the electronic mechanism is a step-by-step procedure. Is mandatory that the voter make a choice for every office in order to vote for the next one. Therefore, this increase the importance of the order of the candidates in terms of the cognitive assimilation of the range of choices

\footnotetext{
${ }^{11}$ The rules are defined in the Electoral Code, established by the Law 4737 of 1965 .

${ }^{12}$ The States Alagoas, Amapá, Rio de Janeiro and Roraima had electronic voting for all municipalities
} 
during the voting procedure when compared to the paper ballot. ${ }^{13}$ Several supporters of the electronic voting adoption advocate that besides the explicit change of the voting mechanism, the fact that the electronic voting defined a specific order of the voting process was essential for the impact of the new technology in the election results. ${ }^{14}$

\footnotetext{
${ }^{13}$ The order that the voting process would appear on the machine screen was defined in the Paragraph 3 of Article 59 of Law 9504/1997, where it is stated that the elector should choose first his deputies and senator candidates, following by the governor and the president

${ }^{14}$ In 2010, the Superior Electoral Court changed the order of voting, being the State deputy office the first choice in the electronic voting machine. This change resulted in a great discussion in Chamber of deputies (GALLUCCI, 2010).
} 


\section{Outcomes derived from electronic voting technology introduc- tion}

A striking achievement of the adoption of the Direct Recording Electronic (DRE) voting system in Brazil is the enfranchising effect, concentrated mainly on the State and Federal deputy elections. This effect is clear on table 1: the difference on valid votes between 1994 and 1998 election is approximately 20 points for the legislative offices (an effect weaker in other offices). In terms of population, this means near 16 millions "new" electors expressing their political preference. Both figures 5 and 6 illustrates this effect on heat map representations.

Table 1: Valid and invalid votes

\begin{tabular}{|c|c|c|c|c|c|c|}
\hline & \multicolumn{6}{|c|}{ Share of Votes, per office } \\
\hline & \multicolumn{3}{|c|}{1994 Election } & \multicolumn{3}{|c|}{1998 Election } \\
\hline & $\begin{array}{r}\text { Valid } \\
\%\end{array}$ & $\begin{array}{c}\text { Blank } \\
\%\end{array}$ & $\begin{array}{c}\text { Spoiled } \\
\%\end{array}$ & $\begin{array}{r}\text { Valid } \\
\%\end{array}$ & $\begin{array}{c}\text { Blank } \\
\%\end{array}$ & $\begin{array}{c}\text { Spoiled } \\
\%\end{array}$ \\
\hline President & 81.2 & 9.2 & 9.6 & 81.3 & 8.0 & 10.7 \\
\hline State Governor & 74.2 & 17.9 & 8.0 & 79.3 & 12.0 & 8.7 \\
\hline Senator & 61.5 & 27.8 & 10.7 & 74.3 & 13.7 & 12.1 \\
\hline Federal Deputy & 58.3 & 16.5 & 25.2 & 80.0 & 10.2 & 9.8 \\
\hline State Deputy & 64.5 & 14.4 & 21.0 & 82.5 & 8.6 & 8.9 \\
\hline
\end{tabular}

Source: Superior Electoral Court (TSE)
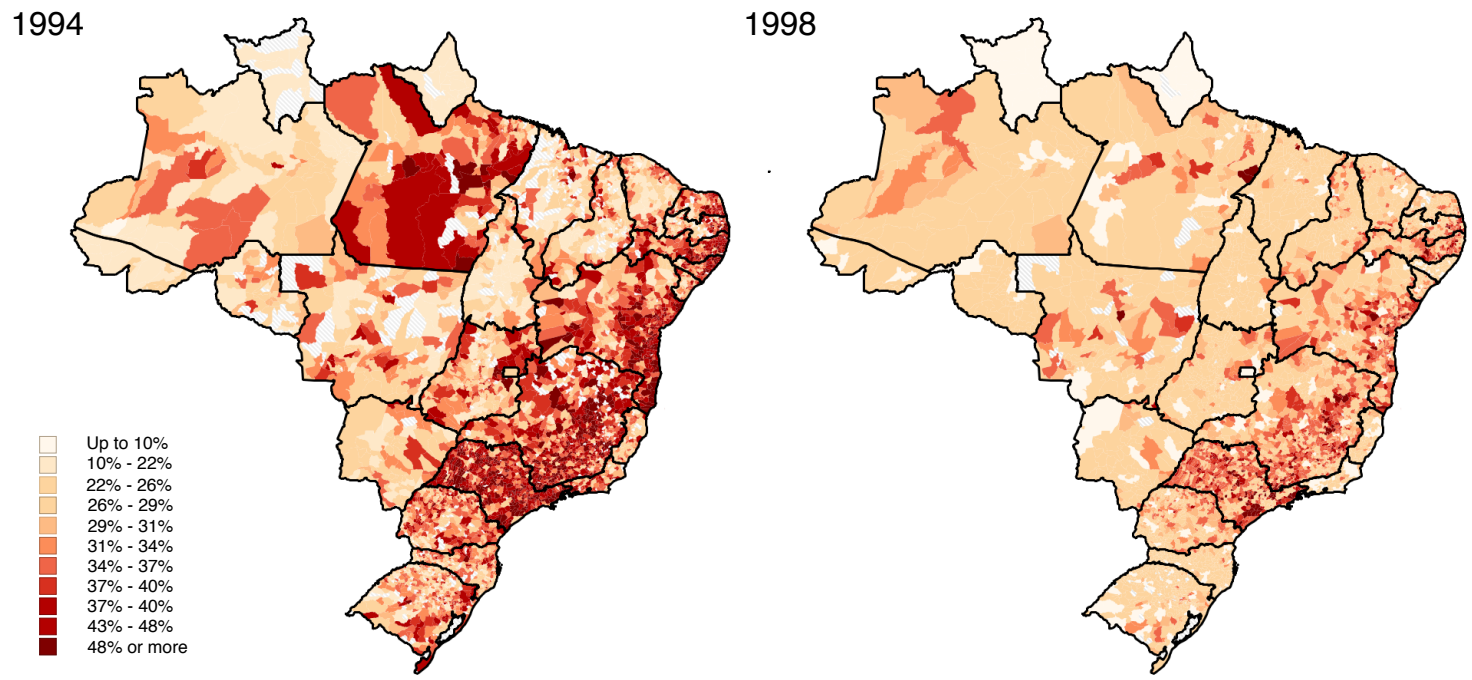

Figure 5: Invalid votes (blank plus spoiled) for State deputy election 

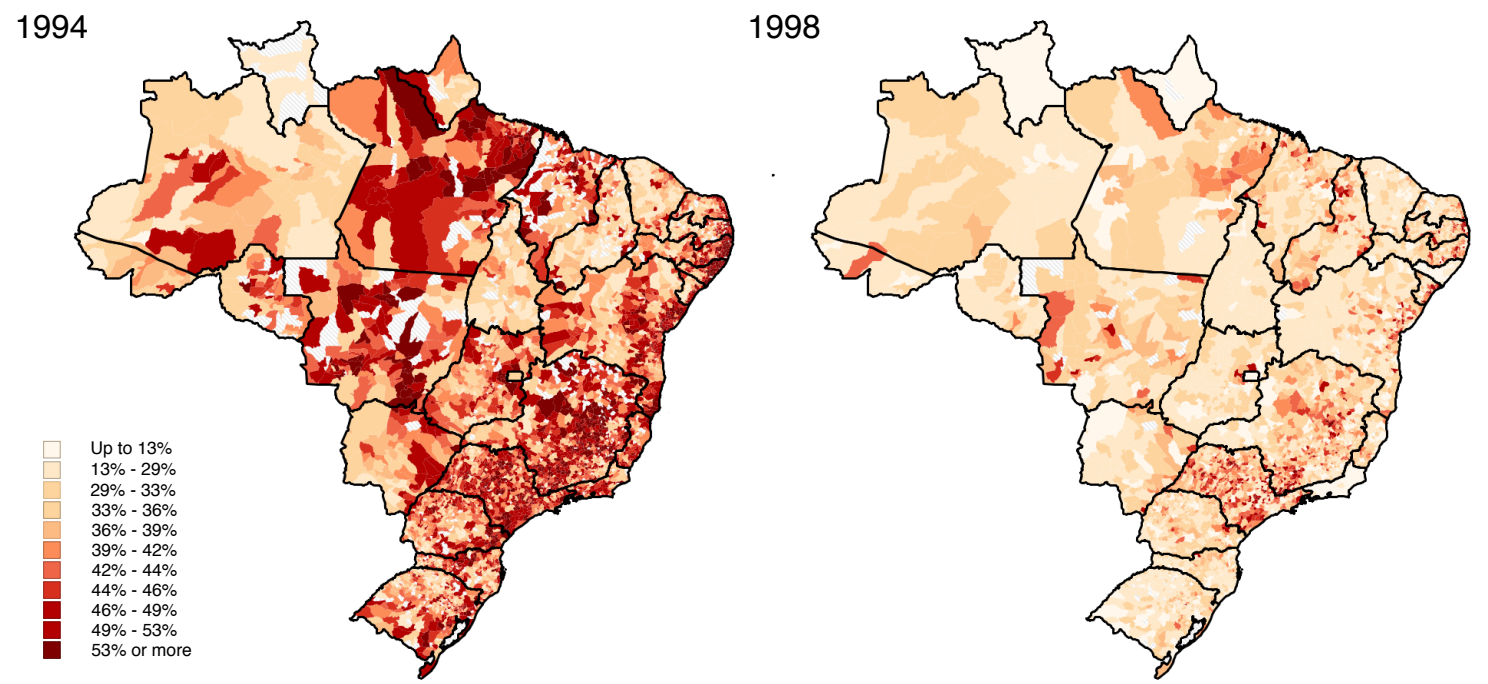

Figure 6: Invalid votes (blank plus spoiled) for Federal deputy election

The drastic reduction of spoiled votes caused by new voting technology was related to the several characteristics listed before that associated compulsory elections and the paper ballot with high levels of invalid votes. It is important to notice that the pattern that blank votes display over the same period are different from the ones observed on the spoiled ones. If we expected no difference between a blank and a spoiled vote than, relatively to the initial level, the decrease should be close in both kind of vote. Nonetheless, as table 1 shows the impact is more significant over the spoiled ones. This fact, contrary to what equivalence between the blank and spoiled votes would imply, suggest that the Direct Voting Mechanism (DRE) have an impact correlated to the reason voters register a spoiled vote. One explanation is that while blank votes are a result of omitting a vote registration a spoiled votes are caused both by a misrepresentation of a political preference, due to the inability of the voter to express it (or to a vote invalidation in the accountability process) or by an explicit manifestation of his dissatisfaction over the status quo politics. Nicolau (2004) analyses and concludes that the low level of education of Brazilian electors was a huge obstacle when associated with the complexity of the paper ballot. Nonetheless, the heterogeneity of the impact on blank and spoiled votes among different offices suggests that hardly one single explanation will be able to fully explain the behavior of these types of votes.

It is important to highlight here that in 1997 Brazilian legislators altered the vote accountability rules which made blank votes considered invalid (spoiled votes were considered as such). Before that change, a candidate vote share was calculated over the sum of all candidates and party code votes plus the blank ones. For the legislatives offices this 
should not affect electors' decision between this two kinds of vote, since the election result depends only on simple majority. But for the executive offices, the Electoral Code dictates that the election must enter into a second runoff round if no candidate secures an outright majority in the first round. As so, a blank vote could strategically be used to increase the total valid votes in order to guarantee a second round. ${ }^{15}$ The new legislation decreased the attractiveness of blank votes in relation to the spoiled ones by making them equivalent in terms of electoral result for executive offices.

Back to the spoiled votes, we argue that since their reduction equals choosing candidates or parties, our investigation relies also on the electoral behavior of this "new" electors. Whether they act or not, in terms of political preference, as the ones who could already express their preference, is a major issue for understanding the political outcome of this voting system change. There are reasons to believe that these voters are different, considering socioeconomic aspects, from the others not previously enfranchised. The reason for that steams from the explanation of why the paper ballot leads to so many spoiled and blank votes. On the assumption that the obstacles created by the paper voting are negatively correlated with education (i.e., the difficulty of writing a name or a number is associated with poor education background), enfranchising is potentially bigger on municipalities with lower education indicators. In despite of that, it is still relevant to identify what vote pattern would be associated with this education background. Considering valid votes for legislative elections, we can divide them between party code and candidate votes, which provides us the information summarized in table 2 and a possibility to generate different hypothesis on this matter.

Table 2: Candidate and party code vote

\begin{tabular}{|c|c|c|c|c|c|c|c|c|}
\hline & \multicolumn{8}{|c|}{ Share of votes, over valid votes } \\
\hline & \multicolumn{4}{|c|}{ Paper Ballot } & \multicolumn{4}{|c|}{ Electronic Voting } \\
\hline & \multicolumn{2}{|c|}{94} & \multicolumn{2}{|c|}{98} & \multicolumn{2}{|c|}{94} & \multicolumn{2}{|c|}{98} \\
\hline & \multicolumn{2}{|c|}{ CandidateParty } & \multicolumn{2}{|c|}{ CandidateParty } & \multicolumn{2}{|c|}{ CandidateParty } & \multicolumn{2}{|c|}{ CandidateParty } \\
\hline Federal Deputy & 96.1 & 3.9 & 94.6 & 5.4 & 88.1 & 11.9 & 81.2 & 18.8 \\
\hline State Deputy & 97.3 & 2.7 & 95.8 & 4.2 & 89.4 & 10.6 & 79.2 & 20.8 \\
\hline
\end{tabular}

Table 2 displays that in cities that used the Direct Recording Electronic (DRE), the party code vote share (over valid votes) increased almost five times more than cities where the

\footnotetext{
${ }^{15}$ Brazilian electoral law established, after the Constitutional reform of 1988, municipalities with more than 200,000 eligible voters were required to adopt a two-ballot system
} 
paper ballot was used. This suggest that what we have been calling of "new electors" have a propensity to choose parties over candidates. In fact, considering just the electoral rules defined by the Electoral Code, paper ballot should have a larger proportion of party votes in comparison to the electronic voting system, since voting mistakes could be counted as party votes. For instance, if an elector mistakenly wrote two candidates from the same party or if he wrote a name that could indicate more than one candidate from the same party that vote would be counted as a party vote (instead of being discarded). But what we observe is that municipalities with electronic voting had a larger proportion of party code votes. 


\section{Methodology and Data Structure}

Our data on municipality characteristics are from the 1991 Census of Population, previous to both elections, provided by the Brazilian Institute of Geography and Statistics (Instituto Brasileiro de Geografia e Estatística - IBGE). The socioeconomic variables used are: average years of schooling of the population; the percentage of the city population living in rural areas; infant mortality (number of deaths of children less than 1 year old per 1000 live births); percentage of houses with electricity and telephone; wealth inequality (Theil Index); longevity HDI.

The political variables are from the Superior Electoral Court (Tribunal Superior Eleitoral). They comprehend all the elections results and the electorate statistics. The electorate variables are: number of electors; percentage of female, elerdely (age $\geq 60$ ) and young (age $\leq 25$ ) electors (\%); mayor's party code and vote share on the previous election; percentage of electors affiliated with a political party; density of voting location (number of voting location per $\mathrm{km}^{2}$ ) and number of electors per voting location. ${ }^{16}$

All of the previous variables are used in standard values, except for the total number of electors that is used in deviation from the elector's threshold $(40,500)$. Finally, the municipality financial data were obtained from the Brazilian Institute of Geography and Statistics (Profile of Brazilian municipalities: survey of basic municipal information). Financial data availability allows us only to compare the years of 1998 and 1999 with the data from IBGE. We also user data from the National Secretary of Treasury - Ministry of Finance (Secretaria do Tesouro Nacional - Ministé rio da Fazenda), called Brazilian Finances (FINBRA). The number of observations for this data is smaller, but in this case we have data availability for the years of 1997 and 1999 .

\subsection{Voting technology affecting election results}

On the election results side, there are two important patterns that have previously come to our attention. First, that the electronic voting is associated with a reduction in the number of invalid votes (perhaps attributed to mistakes). Second, that the inclusion "new" electors is correlated with an increase in party code votes. Considering this two patterns, we now to move a step further and inquire about the possible outcomes of politicians' behaviors in response to this changed scenario.

\footnotetext{
${ }^{16}$ The mayor elections previous to the elections that we analyze occurred in 1992 and 1996.
} 
In order to provide solid grounds for our argumentation, we employed a sequence of four statistical tests related to the election and political variables. A., we show that the reduction of invalid votes attributed to the electronic system is statistic significant. B., we find strong evidence that the voting enfranchising also affects political competition, by making elections more competitive. C., we follow by investigating the impact of the mayor party and party performance in general. Finally, D., we analyze how this change on political competition can result on a final impact on the allocation of municipalities' resources.

We run pooled OLS regressions to evaluate the impact of the electronic voting on election results. Our dataset is composed by two elections (1994 and 1998). ${ }^{17}$ In 1994, the voting system was manual in every municipality while, in 1998, municipalities with more than 40,500 voters used the electronic voting system. Thus, our approach is to use the municipalities that used the manual voting system in both elections as a control group for the municipalities that changed their system to the electronic one in 1998. We also run fixed effects estimations in order to reduce the chances of running into an omitted variables bias problems.

As mentioned before, the States Alagoas, Amapá, Rio de Janeiro and Roraima had electronic voting for all municipalities. Therefore they are excluded from our analysis. Moreover, we ignore 57 municipalities that adopted the electronic voting in the 1996 mayor election and 33 municipalities that violate the threshold either by using the electronic voting when they have less than 40,500 or by not using it when they have more. We also ignore municipalities that were created between the 1994 and 1998 election, since we are unable to compare the election results of those municipalities for both years (and all of them don't adopt the electronic voting, for being small and recently created cities). We also ignore one municipality that had more than 40,500 electors registered in 1994 and was divided in this interim, loosing enough registered electors so that it fell below the threshold in 1998 . It is important to notice that those exclusions are unlikely to bias our analysis since we also proceed with our investigation using the full sample, which leads to no substantial change on our results. Rather than that, it gives more robustness to our findings.

Our approach is based on two assumptions: first, that the only unobservable difference between control group municipalities and the treatment group municipalities is fixed over time; and second, that the composition of voters is the same during periods.

For the first assumption, it is reasonable to expect that variables which could change the

${ }^{17}$ After, we use the 2002 election as a placebo 
election pattern on canceled votes from one city to another did not change dramatically from 1994 to 1998. Education, social capital and political engagement which are usually mentioned as determinants of the elections outcomes do not change substantially in a short period of time (besides we control for electors age and sex composition and for political engagement - using the data on electors affiliated with parties). Also, there were no structural changes on the electoral system that could invalidate our results.

As for the second assumption, a comprehensive share of this bias was controlled using multiple covariates. Besides that, the fact that voting is mandatory, results in a high vote turnout average of $79.8 \%$ in 1994 and $76.5 \%$ in 1998 election. ${ }^{18}$ A possible remaining the bias after controlling for the characteristics of the municipalities is the new mechanism impact on the composition of voters bringing those who would not vote with the manual voting technologies. In that sense, we also investigate how the electronic voting affects voting turnout and how this connection depends on municipalities' covariates.

In order to support the assumption that the municipalities with paper ballot are a valid control group for the ones that adopted the DRE voting technology the images bellow displays that the discontinuity on vote patterns associated with the introduction of the electronic voting (represented by blank and spoiled votes) is not observed when we analyze the covariates.
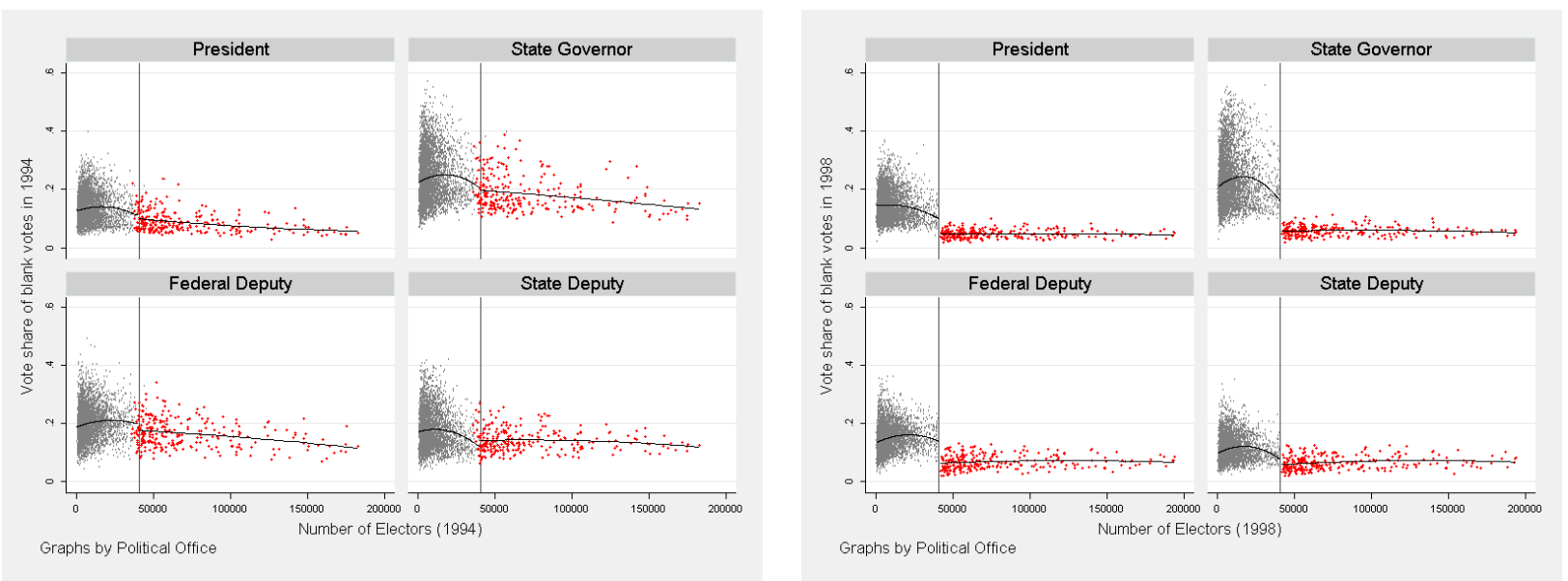

Figure 7: Blank Votes behavior

\footnotetext{
${ }^{18}$ In US presidential election, vote turnout is around 50\% (56.8\% in 2008 elections, according to http: //elections.gmu.edu/Turnout_2008G.html)
} 

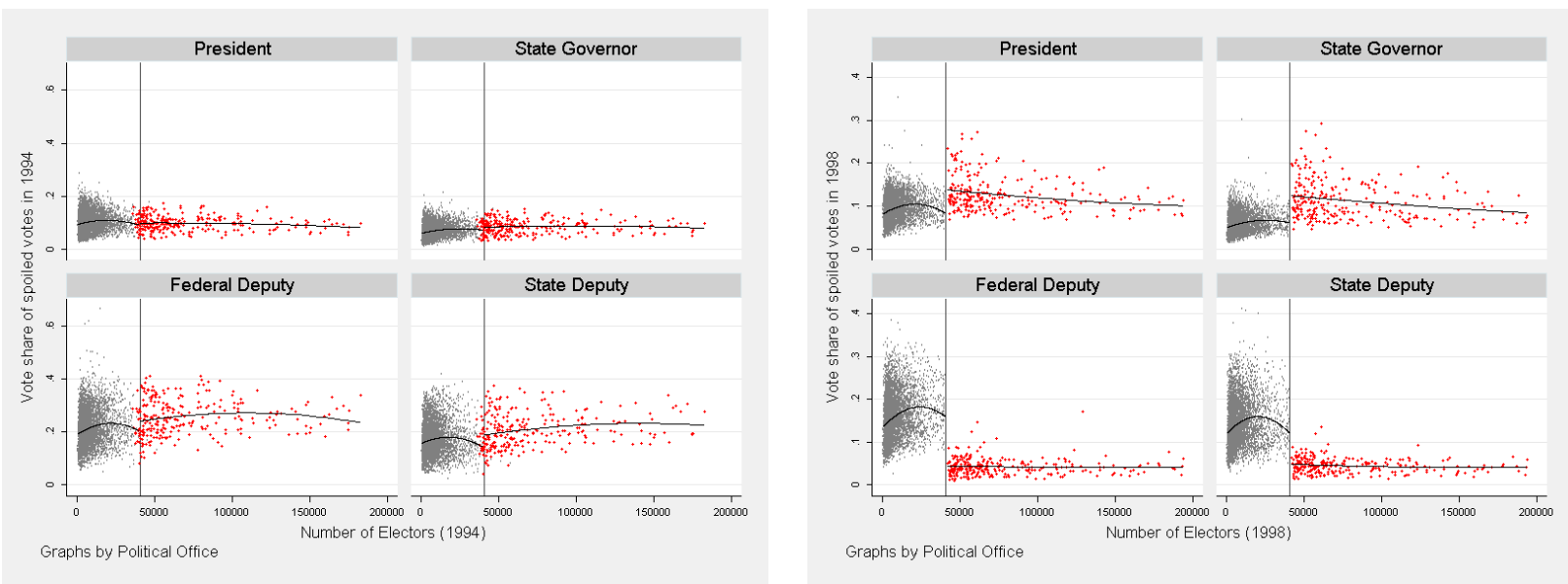

Figure 8: Spoiled Votes behavior

This first four graphs strongly reinforce the statement previously made: the introduction of a new voting technology promoted a striking change on (mainly) legislative election, allowing more electors to express their political preference. Both blank and spoiled votes display a rupture between the 1998 election and the previous one. As for municipalities covariates the graphical analysis bellow suggests no discontinuity on covariates around the 40,500 electors threshold.
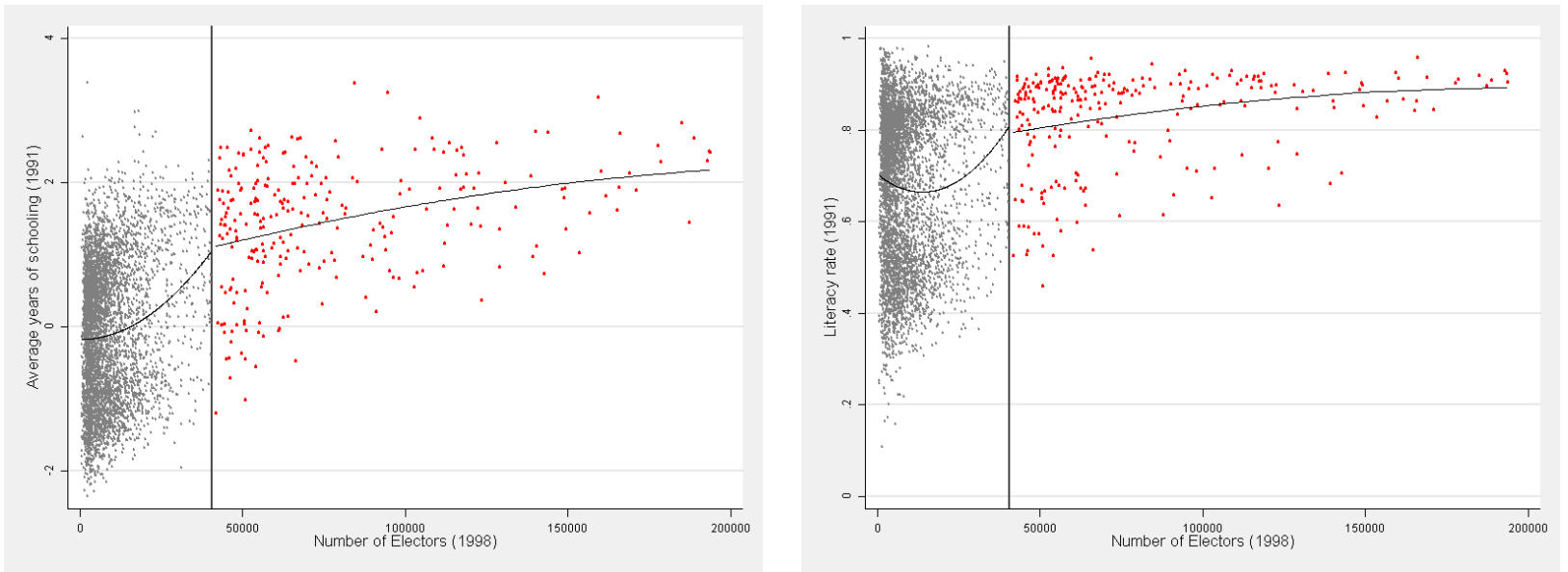

Figure 9: Covariates behavior (1) 

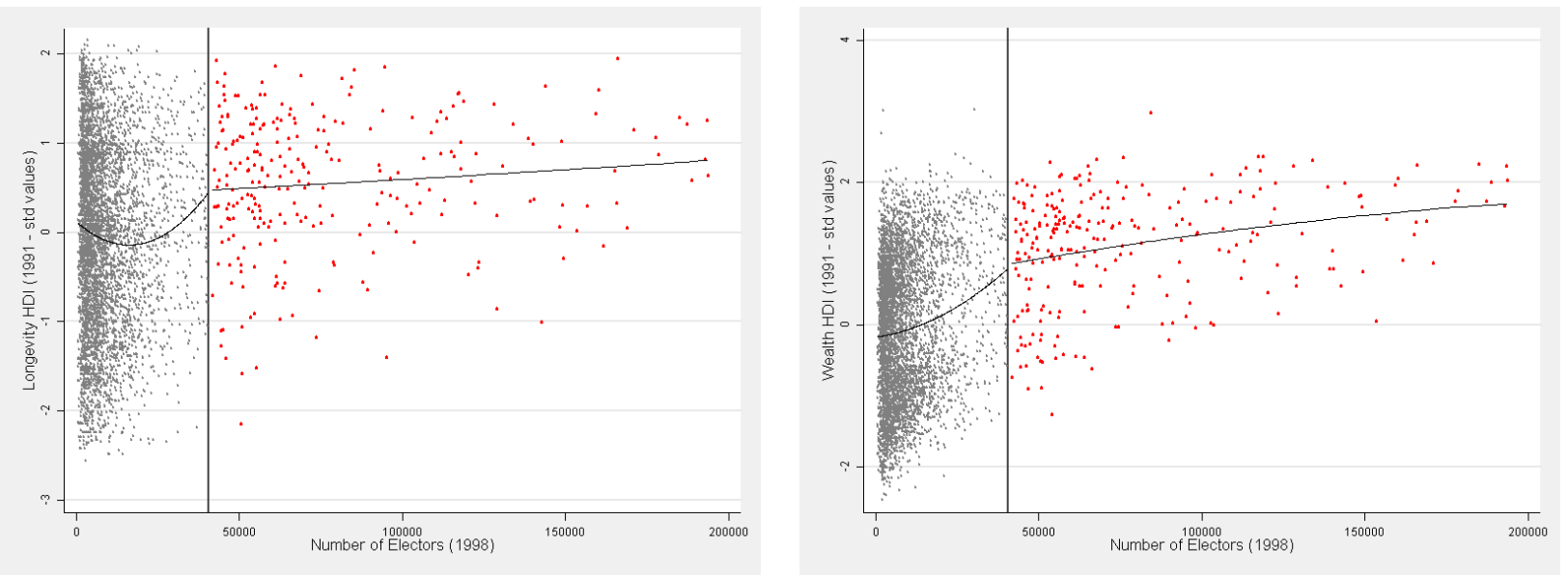

Figure 10: Covariates behavior (2)
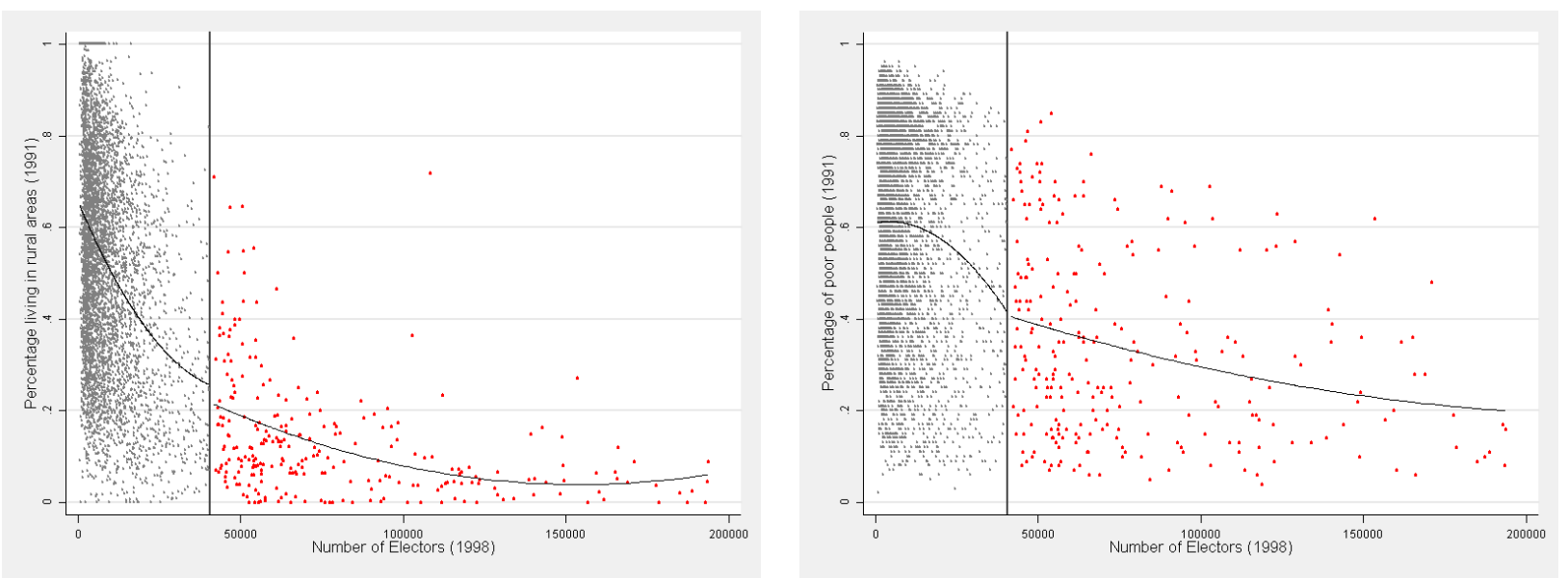

Figure 11: Covariates behavior (3)

We use the following specification as the baseline to investigate the impact of electronic voting on our variables of interest:

$$
\begin{aligned}
y_{m, t, o}^{k}= & \alpha+\sum_{i=1}^{N} \beta_{i} x_{m, t, o}^{i} \\
& +\gamma_{0} e v_{m}+\sum_{j=1}^{M} \gamma_{j} e v_{m} * x_{m, t, o}^{i} \\
& +\eta_{0} e v_{m} * T_{t}+\sum_{j=1}^{M} \eta_{j} e v_{m} * T_{t} * x_{m, t, o}^{i} \\
& +\delta_{0} T_{t}+\sum_{j=1}^{M} \delta_{j} * T_{t} * x_{m, t, o}^{i} \\
& +\delta_{M+1} S_{m}+\varepsilon_{m, t, o}
\end{aligned}
$$


where,

- $y_{m, t, o}$ is the variable of interest related with the elections in the municipality $m$, office $o$, the time $t$.

- $e v_{m}$ is a dummy variable that assumes the value of 1 if if the electronic voting took place in municipality $m$ in 1998 and zero otherwise.

- $x_{i, m}$ are the $N$ variables that captures municipalities' level factors that varies across municipalities but are fixed over time.

- $S_{m}$ is a State dummy for the municipality $m$.

- $T_{t}$ is a time dummy that equals 1 if $t=1998$.

- the interactions between the dummies and the covariates capture how electronic voting might affect the impact of specific municipalities' characteristics on elections.

- $\varepsilon_{m, t, o}$ is a zero mean variable assumed to be independent of both the observed right side variables and the fixed effects.

One final remark about our sample is that we don't use senator's elections results. The reason for the exclusion is that after 1978 the number of senators increased from two to three per State, resulting in a seasonality in which two-thirds of the upper house is up for election at one time and the remaining one-third four years later. In 1994, electors had to choose 1 senator only while in 1998 they had to vote for two candidates. We decided to exclude this office election based on the fact that patterns associated with it are not strictly comparable.

\subsection{Blank and spoiled votes}

The most relevant electoral characteristic associated with the introduction of the electronic voting is the increase of valid votes. We believe that the system made the voting process easier and because of that it reduced the number of invalid votes (which is correlated with the difficulty of voting, usually attributed to the legislative elections). Through the framework of our baseline equation, we can also analyze if others characteristics from the municipality also affects the elections results when associated to different voting mechanisms. A usual hypothesis of the impact of electronic voting was that the reduction of invalid votes should be greater for the less educated groups (since the voting mechanism 
based on the paper ballot could represent a greater obstacle for them when compared to higher educated groups). Nonetheless, as we shall demonstrate ahead, we find a robust evidence of other relevant electors' characteristics that influence this type of vote. We also investigate whether the type of vote invalidation, blank and spoiled, are differently affected by the DRE and the municipalities' covariates.

\subsection{Political Competition}

Since electronic voting results in enfranchising, then an intriguing effect, but rather complex, is how these electors are affecting election results. A fractionalization index can give a big picture about the behavior of the "new" votes. In other words, does this increase in vote count make vote distribution more or less concentrated?

We employ a measure of heterogeneity based on the well known index of ethno-linguistic fractionalization (ELF), broadly used in the empirical Economics literature. ${ }^{19}$ It consists of a decreasing transformation of the Herfindahl concentration index. Assuming a society with $H \geq 2$ groups, this index basically indicates the probability of choosing two individuals that belongs to different groups. In our case, assuming that in the municipality $m$ we have $H_{m}$ candidates, the fractionalization index would be

$$
F_{m}=1-\sum_{h=1}^{H_{m}} v s_{h, m}^{2}
$$

where $v s_{h, m}$ is the vote share of candidate $h$ in municipality $m$. Basically it indicates how concentrated the vote distribution among candidates of each municipality is. In one extreme, as the vote share of each candidates converge to zero this fractionalization index approximates to one implying that elections are really competitive. On the other extreme, as the vote share of one candidate grows to one, $F_{m}$ reduces to zero meaning the votes are completely concentrated. ${ }^{20}$ We use again the same specification defined in equation 4.2 , replace $y$ by $F_{m, t, o}$, the fractionalization index for the office $o$, in municipality $m$, in election $t$.

The fact that the number of candidates is fixed in State level, regarding governor, Federal and State deputy election allow us to compare the fractionalization index by controlling for State variables. Number of president candidates, naturally, is the same for all municipalities. By controlling by the number of parties that participates on the election and the number of candidates we are able to isolate the effect that an increase in competi-

\footnotetext{
${ }^{19}$ See Bossert et al. (2011).

${ }^{20}$ Given the same number of candidates.
} 
tion before the election (increase in number of candidates and parties) imply in an real vote decentralization. Anyway, as displayed on the picture bellow, there is not a great difference in the number of parties between the analyzed election.
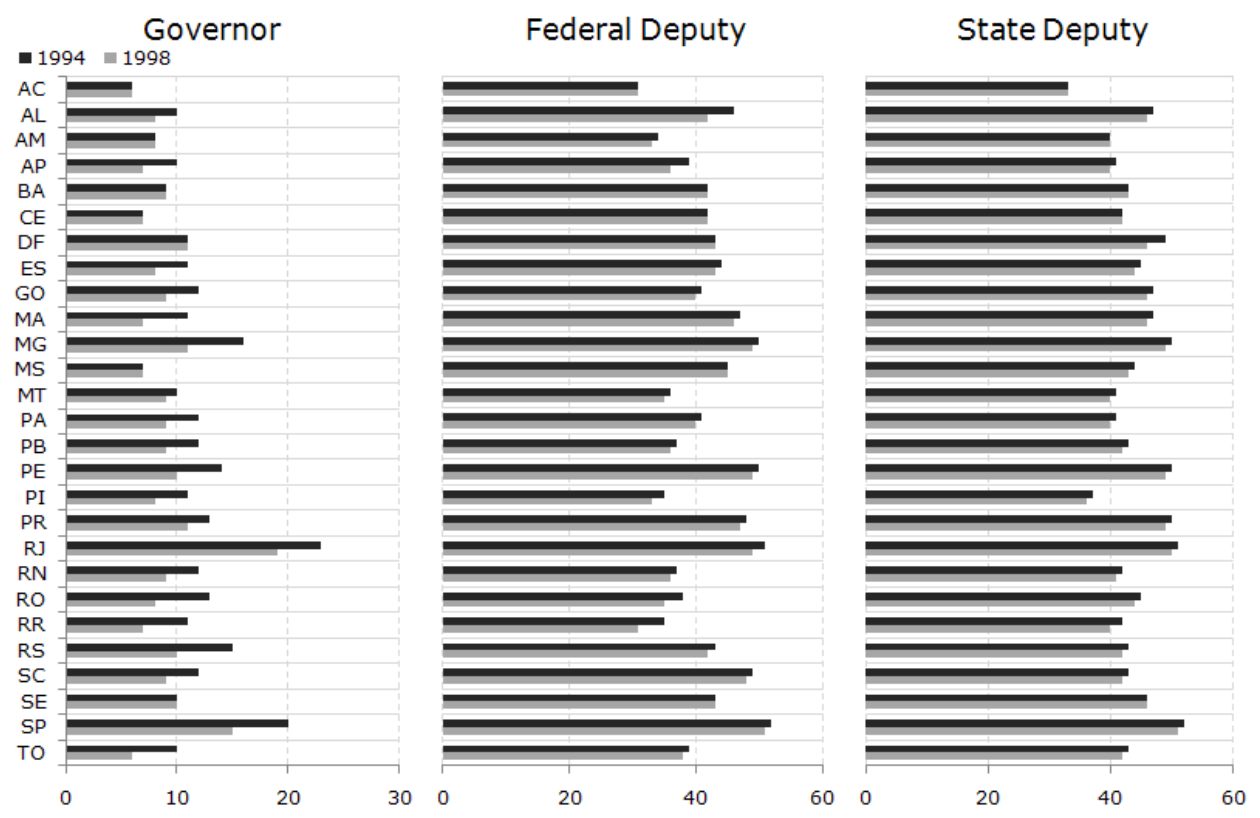

Figure 12: Number of parties disputing each office in each State

In another matter, we investigate whether the legislative election produces viable candidates for future mayors elections and if electronic voting affects these candidates. Our assumption is that candidates that have a good performance for State deputy office, do not belong to the party of the incumbent mayor but were not elected constitute a set of possible candidates for the mayor elections held to years later. From 1998 election data, we find out that $5.98 \%$ of the candidates for State deputy (629 candidates, from which 536 were not elected in 1998) are also candidates for mayor in $2000 .^{21}$

So, for selecting this candidates, we created an identification that we called the "best loser", which was based on two aspects. First, as said before, our object of analysis are the candidates for State deputy who were not elected in 1998. Second, among those candidates we are interested on the ones who had built a reasonable amount political capital in order to become candidates for the mayor office. In sum, translation of this identification is the candidate with the best performance in the municipality that wasn't

\footnotetext{
${ }^{21}$ In order to identify State deputy candidates in 1998 with mayor candidates in 2000 we had to merge candidate information based on three characteristics: full name, birth date and State. For the first two characteristics, probability merging allowed us to identify candidates even when there were mistyping or error. The third one was used as cut off characteristic, since comparing all candidates of the country would give us not only a database size difficulty but also a discretionary, since we wouldn't be able to rigorously distinguish candidates with similar names and birth date. We believe that a misrepresentation of this variable (not finding candidates that ran for both elections) does not bias our results.
} 
from the mayor party, among those who were running for State deputy, but that wasn't elected.

We developed an assignment mechanism in order to identify one "best loser" per municipality, since a candidate could be the "best loser" in several cities. This mechanism assigned for "best losers" of multiple cities the municipality that were the most important in terms of the candidate 1998 total votes (the sum of the votes that he received from all cities of the State). The assignment was iterated several times, dropping for each round the candidates who were identified as "best loser", so that each city had exactly one best loser. To summarize, the mechanism goes as follow:

i. Identify the "best loser" for each municipality from parties different from the mayor one (elected in 1996);

ii. Among those who are multiple "best losers", assign it to the most representative city over his own total vote;

iii. Exclude from the analysis the uniquely identified "best losers";

iv. Repeat until all municipalities have one "best loser" (or until exists possible best losers candidates).

For the "best loser" assignment, we considered both State and Federal deputies candidates and also only State deputies candidates. As for investigating these candidates, we used the the following specification

$$
\begin{aligned}
v s_{m, t, o}^{\text {bloser }}= & \alpha+\sum_{i=1}^{N} \beta_{i} x_{m, t, o}^{i} \\
& +\gamma_{0} e v_{m}+\sum_{j=1}^{M} \gamma_{j} e v_{m} * x_{m, t, o}^{i} \\
& +\eta_{0} e v_{m} * T_{t}+\sum_{j=1}^{M} \eta_{j} e v_{m} * T_{t} * x_{m, t, o}^{i} \\
& +\delta_{0} T_{t}+\sum_{j=1}^{M} \delta_{j} * T_{t} * x_{m, t, o}^{i} \\
& +\delta_{M+1} S_{m}+\varepsilon_{m, t, o}
\end{aligned}
$$

where,

- $v s_{m, t, o}^{k}$ is the vote share in the municipality $m$ in office $o$ in the time $t$. 
- $e v_{m}$ is a dummy variable that assumes the value of 1 if if the electronic voting took place in municipality $m$ in 1998 and zero otherwise.

- $x_{i, m}$ are the $N$ variables that captures municipalities' level factors that varies across municipalities but are fixed over time.

- $S_{m}$ is a State dummy for the municipality $m$.

- $T_{t}$ is a time dummy that equals 1 if $t=1998$.

- the interactions between the dummies and the covariates capture how electronic voting might affect the impact of specific municipalities' characteristics on elections.

- $\varepsilon_{m, t, o}$ is a zero mean variable assumed to be independent of both the observed right side variables and the fixed effects.

In order to analysis the probability of this kind of candidate running for mayor in the next election, we used a similar specification in a linear probability model:

$$
\begin{aligned}
M_{m, t, o}^{\text {bloser }}= & \alpha+\alpha_{0} * v s_{m, t, o}^{\text {bloser }}+\sum_{i=1}^{N} \beta_{i} x_{m, t, o}^{i} \\
& +\gamma_{0} e v_{m}+\sum_{j=1}^{M} \gamma_{j} e v_{m} * x_{m, t, o}^{i} \\
& +\eta_{0} e v_{m} * T_{t}+\sum_{j=1}^{M} \eta_{j} e v_{m} * T_{t} * x_{m, t, o}^{i} \\
& +\delta_{0} T_{t}+\sum_{j=1}^{M} \delta_{j} * T_{t} * x_{m, t, o}^{i} \\
& +\delta_{M+1} S_{m}+\varepsilon_{m, t, o}
\end{aligned}
$$

where,

- $M_{m, t, o}^{\text {bloser }}=1$ if the "best loser" is a mayor candidate in his city in the election hold two years after the legislative one.

- $v s_{m, t, o}^{k}$ is the "best loser" vote share in the municipality $m$ in office $o$ in the time $t$.

- $e v_{m}$ is a dummy variable that assumes the value of 1 if if the electronic voting took place in municipality $m$ in 1998 and zero otherwise.

- $x_{i, m}$ are the $N$ variables that captures municipalities' level factors that varies across municipalities but are fixed over time. 
- $S_{m}$ is a State dummy for the municipality $m$.

- $T_{t}$ is a time dummy that equals 1 if $t=1998$.

- the interactions between the dummies and the covariates capture how electronic voting might affect the impact of specific municipalities' characteristics on elections.

- $\varepsilon_{m, t, o}$ is a zero mean variable assumed to be independent of both the observed right side variables and the fixed effects.

\subsection{Paper Ballot Impact}

Besides allowing for an evaluation of the new voting system, the introduction of the electronic voting also permitted a unique opportunity to analyze framing characteristics impact of the paper ballot system. Specifically, we test whether the order of the candidates that appear in the paper ballot and their position impact their vote casts. As displayed in image 3 for the president, State governor and senator election the paper ballot displays a list of all candidates, being the order defined by an official draw, as defined by the Paragraph 1 of Article 104 of the Electoral Code (Law 4737/1965). Table 3 shows the presidential candidates of 1998 election, ordered in the exact same way as the paper ballot, and the election result (where Fernando Henrique Cardoso became the first reelected president, winning in the first round as he achieved more than $50 \%$ of the valid votes).

Table 3: Paper ballot order and 1998 President Election Results

\begin{tabular}{|c|c|c|c|c|c|}
\hline \multicolumn{3}{|c|}{ Candidate } & \multirow[t]{2}{*}{ Party } & \multirow[t]{2}{*}{ Votes } & \multirow[t]{2}{*}{ Vote Share } \\
\hline Position & Code & Name & & & \\
\hline 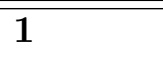 & $2 \overline{23}$ & Ciro Ferreira Gomes & $\overline{\mathrm{PPS}}$ & $7,426,187$ & $10,97 \%$ \\
\hline 2 & 70 & João de Deus Barbosa de Jesus & PT do B & 198,915 & $0.29 \%$ \\
\hline 3 & 13 & Luiz Inacio Lula da Silva & $\mathrm{PT}$ & $21,475,211$ & $31.71 \%$ \\
\hline 4 & 27 & José Maria Eymael & PSDC & 171,831 & $0.25 \%$ \\
\hline 5 & 33 & Ivan Moacyr da Frota & PMN & 251,336 & $0.37 \%$ \\
\hline 6 & 45 & Fernando Henrique Cardoso & PSDB & $35,936,382$ & $53.06 \%$ \\
\hline 7 & 16 & José Maria de Almeida & PSTU & 202,659 & $0.30 \%$ \\
\hline 8 & 19 & Thereza Tinajero Ruiz & PTN & 166,138 & $0.25 \%$ \\
\hline 9 & 20 & Sergio Bueno & PSC & 124,569 & $0.18 \%$ \\
\hline 10 & 31 & Vasco Azevedo Neto & PSN & 109,003 & $0.16 \%$ \\
\hline 11 & 56 & Eneas Ferreira Carneiro & PRONA & $1,447,089$ & $2.14 \%$ \\
\hline 12 & 43 & Alfredo Hélio Syrkis & $\mathrm{PV}$ & 212,983 & $0.31 \%$ \\
\hline
\end{tabular}

Source: Superior Electoral Court (TSE)

As in Dee (2007), we investigate whether candidates positioned near the stronger ones are benefited just because they are "bookend" candidates (i.e., candidates positioned in the 
paper ballot in front of and behind the two major candidates) in municipalities where the paper ballot is adopted. It is reasonable to expect that smaller candidates are benefited by the use of the paper ballot since those candidates attract less media attention and usually have smaller election campaigns and, therefore, could be helped by the fact that the paper ballot "helps" electors that forgot either there candidates name or number (since all the elector has to do is to read the ballot and fill a check box). Nonetheless, if electors have already chosen their candidates (and remember them), there is no reason to expect that in the being placed near strong candidates should have an impact on this candidates performance.

Table 4: Paper ballot order and 1994 President Election Results

\begin{tabular}{|c|c|c|c|c|c|}
\hline \multicolumn{3}{|c|}{ Candidate } & \multirow[t]{2}{*}{ Party } & \multirow[t]{2}{*}{ Votes } & \multirow[t]{2}{*}{ Vote Share } \\
\hline Position & Code & Name & & & \\
\hline$\overline{1}$ & 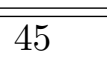 & Fernando Henrique Cardoso & $\overline{\text { PSDB }}$ & 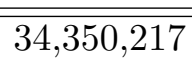 & $\overline{54.28 \%}$ \\
\hline 2 & 15 & Orestes Quercia & PMDB & $2,771,788$ & $4.38 \%$ \\
\hline 3 & 36 & Carlos Antonio Gomes & PRN & 376,183 & $0.59 \%$ \\
\hline 4 & 13 & Luiz Inacio Lula Da Silva & $\mathrm{PT}$ & $17,112,255$ & $27.04 \%$ \\
\hline 5 & 11 & Esperidiao Amin Helou Filho & PPR & $1,739,458$ & $2.74 \%$ \\
\hline 6 & 20 & Hernani Goulart Fortuna & PSC & 238,126 & $0.37 \%$ \\
\hline 7 & 56 & Eneas Ferreira Carneiro & PRONA & $4,670,894$ & $7.38 \%$ \\
\hline 8 & 12 & Leonel De Moura Brizola & PDT & $2,015,284$ & $3.18 \%$ \\
\hline
\end{tabular}

We also investigate whether the fact that the electronic voting impose a unique order for all electors also contributed for the impact of the new technology. Many argues that, by forcing the electors to cast votes for the legislative offices before choosing the State Governor and the President, the electronic machine could induce people to vote for party code votes for the first votes thinking they were choosing the President or the State Governor (as they would do if they were using the paper ballot). Critiques of the vote order to argue that a common tale of recent elections is the one of elector choosing two votes and leaving the vote cabin, thinking he has already completed his voting procedure (and being sent back to register the remaining votes). In that sense, we explore the probability of choosing the same party code for both legislative elections, comparing municipalities with paper ballot and the ones with electronic technology.

\subsection{Mayor expenditure}

The last implication of a change in the election competition should be political aspects controlled by the candidates. In relation to the argument constructed in the previous 
sections, should we expect mayors from cities that received the electronic machine acting different from the ones that did not? More specifically, should these mayors change their behavior, comparing the year of the election and the one that follows (1998 and 1999, respectively), in relation to the mayors from cities that remained with the paper ballot?

Our focus in this analysis is the impact of results for any office in the national and State elections (president, governor, senator and the Federal and State deputy) in the mayor decision about resource allocation. Up to this point, we developed an argument that the introduction of the technology in 1998 election affected the level of political competition and altered the status quo of parties and candidates in national elections. Moreover, as pointed before there is an intrinsic connection in Brazilian politics between legislative offices and municipal-level politic. But more than that, a careful discussion about the impact of a change in competition on politics itself highlight a bigger discussion of whether electors affect politics or elect policies. ${ }^{22}$ In other words, if mayor react to the information update brought by the electronic voting, then, in some way, we are inferring that politics react to the electors' preference in order to win the elections. Budgetary status is affected by a variety of factors - the municipality's and its inhabitants' characteristics, incumbent party, government policy. Controlling for municipality covariates and using the difference between the resource allocation between 1998 and 1999 (before and after the elections and the implementation of the electronic voting system) we are able to distinguish the impact of the performance of parties and candidates or the level of political competition in the municipality. Considering that expenditures are divided in $F$ categories, each represent by $f=1, \ldots, F$, we use the following specification, considering 1998 election results and municipalities covariates:

$$
\begin{aligned}
\Delta \operatorname{sh}_{m}^{f}= & \alpha+\sum_{i=1}^{N} \beta_{i} x_{m}^{i}+\gamma_{0} e v_{m}+\sum_{j=1}^{M} \gamma_{j} e v_{m} * x_{m}^{i} \\
& +\delta_{M+1} S_{m}+\varepsilon_{m}
\end{aligned}
$$

where the only differences between this specification and the last ones is the use of $\Delta \mathrm{sh}_{m}^{f}$, the difference of share of the expenditure $f$ in municipality $m$ between 1999 and 1998, and the fact that we can only estimate it using a cross-section analysis. Anticipating our results, we also divide our sample between low level of party code fractionalization and high-level. In words, since the electronic voting may affect political competition, measured by this variable, we test whether the impact of a rise (or a fall) in the level of political

\footnotetext{
${ }^{22}$ See Lee et al. (2004) for a discussion on this matter
} 
competition on the resource allocation depends on the previous level of competition (as in Reingewertz, 2009) by dividing the municipalities located bellow the fractionalization median from the ones above it.

Because of the aforesaid close relation between the legislative office and municipal-level politics, we also investigate whether the electronic voting altered the allocation of budget amendments made by Federal deputies. As Samuels (2003) explains, most of the efforts of deputies with pork-barreling are in direction to pave their future at noncongressional career paths (either at the State or the municipal level) and not necessarily to hold onto their seat. Therefore, we test whether this politics, in face of a shift in municipal-level competition alter their allocation towards (or away from) the cities where this change occurred. Again, we also divide our sample between low level and high level of party code fractionalization to identify whether this impact depends on the previous level of competition. In this case we also compare the share of the budget amendments in municipality $m$, in relation to the total amendment budget, between 1999 and 1997.

\subsection{Robustness Check}

In order to provide solid grounds for our argumentation, we provide a series of tests and estimation variations to verify if our results are robust to different specifications. First, our analysis of the covariates reveals insignificant differences in average covariates between control and treatment groups which could bias most of our results. Second, we estimate most of our results considering two different subgroups of our complete sample. First, we retain our analysis in municipalities around threshold, considering a bin of 20,000 electors (so, we run all the regressions for the sub-extract that has total number of electors between 20,500 and 60,500). Second, we investigate the same variables of interest for the municipalities where the mayor won the 1996 election by a tight margin of victory (less than $5 \%$ ). This would give us a second discontinuity, since we could consider a random assignment of incumbent parties to those municipalities. Finally, we test all of our results using the discontinuity between the 1998 and the 2002 elections. In 2002, municipalities that remained with the paper ballot in the 1998 election adopted the electronic voting. Therefore, we expect an opposite effect of the electronic voting in the municipalities that used the new technology in 1998. All of our robustness tests corroborate our findings, except where explicit mentioned the contrary.

In regard to the analysis of city-level finance, due to lack of information the only robustness check we provide is investigating the same analysis around the population threshold that 
defined the electronic voting discontinuity. 


\section{Results}

This section establish a connection between electoral results and political outcome. We use the introduction of the electronic voting content in order to establish a line of argument, corroborated by statistical evidence, that begins with the enfranchising effect and ends in municipality finance variables, passing through political competition.

The section is organized as follows. A., we show that the reduction of blank and spoiled votes with the electronic voting system is statistically significant; as explained before, this is the core of our enfranchising effect. B., we present how the shift of the voting system affect election outcomes; i.e., since invalid votes does not necessarily impact vote distribution, we identify the increase of party code vote share in the municipality level. C., competitiveness amplification is identified by the vote dispersion and impact in the performance of specific parties. D., we recognize that mayors react to the new competitiveness scenario by changing resource allocation. More specifically, we identify a bias toward health spending derived from an increase in political competition, when the previous level is low.

Our appendices provides all the robustness tests, including a placebo test with the 2002 election data, when all municipalities adopted the electronic voting. Our findings are robust to those tests, except where explicit mentioned the contrary.

\subsection{Invalid votes}

As mentioned before, electronic voting has a huge impact on valid and invalid votes ratio (see table 5). By making the process easier, the new voting system decreased blank plus spoiled votes over turnout, specially concentrated on legislative elections. By itself this is a significant effect: just by changing the voting system, Brazil was able to change a vote structure (large share of invalid votes, with an upward trend) and electors who were unable to choose a candidate (by option or by difficulties imposed by the paper ballot) expressed their preferences differently from what they used to.

As the results in table 5 bellow shows, the impact of the use of electronic voting is significant for all offices (higher for governor and legislative elections) and represents an impact of more than $20 \%$ of invalid votes reduction for Federal deputy. As for the interaction of the electronic voting indicator and the municipality characteristics, we find that the electronic voting impact is bigger among the poor and less educated whenever significant (negative correlation for the percentage of poor people in president election 
and positive correlation with years of schooling in governor and Federal deputy election). As we will see bellow, the association between those covariates and the new technology and the resulting impact in invalid votes will depend whether we are analyzing spoiled or blank votes.

Table 5: Electronic voting impact on Invalid Votes

\begin{tabular}{|c|c|c|c|c|c|c|c|c|}
\hline Dep. Var.: Invalid & Pres & dent & Gove & nor & Federal & Deputy & State & Deputy \\
\hline Regressions & (1) & (2) & (1) & (2) & (1) & (2) & (1) & (2) \\
\hline Electronic Voting (EV) & $\begin{array}{c}0.00206 \\
(0.0054)\end{array}$ & & $\begin{array}{l}0.0133 \\
(0.0094)\end{array}$ & & $\begin{array}{c}-0.0145 \\
(0.0139)\end{array}$ & & $\begin{array}{c}-0.0409^{* * *} \\
(0.0136)\end{array}$ & \\
\hline Year $=1998$ & $\begin{array}{c}0.00248^{* * *} \\
(0.0007)\end{array}$ & $\begin{array}{c}0.00433^{* * *} \\
(0.0007)\end{array}$ & $\begin{array}{c}-0.0237^{* * *} \\
(0.0013)\end{array}$ & $\begin{array}{c}-0.0199 * * * \\
(0.0013)\end{array}$ & $\begin{array}{c}-0.108^{* * *} \\
(0.0015)\end{array}$ & $\begin{array}{c}-0.104^{* * *} \\
(0.0015)\end{array}$ & $\begin{array}{c}-0.0944^{* * *} \\
(0.0014)\end{array}$ & $\begin{array}{c}-0.0916^{* * *} \\
(0.0014)\end{array}$ \\
\hline EV * Year $=1998[\mathrm{EV}(98)]$ & $\begin{array}{c}-0.0460^{* * *} \\
(0.0053)\end{array}$ & $\begin{array}{c}-0.0384^{* * *} \\
(0.0055)\end{array}$ & $\begin{array}{c}-0.116^{* * *} \\
(0.0115)\end{array}$ & $\begin{array}{c}-0.115^{* * *} \\
(0.0114)\end{array}$ & $\begin{array}{c}-0.221^{* * *} \\
(0.0151)\end{array}$ & $\begin{array}{c}-0.226^{* * *} \\
(0.0161)\end{array}$ & $\begin{array}{c}-0.123^{* * *} \\
(0.0150)\end{array}$ & $\begin{array}{c}-0.124^{* * *} \\
(0.0150)\end{array}$ \\
\hline Poor People (\%) & $\begin{array}{c}0.00916^{* * *} \\
(0.0017)\end{array}$ & & $\begin{array}{c}-0.00847^{* * *} \\
(0.0024)\end{array}$ & & $\begin{array}{c}-0.0027 \\
(0.0035)\end{array}$ & & $\begin{array}{c}-0.00502 \\
(0.0033)\end{array}$ & \\
\hline EV $(98) *$ Poor People (\%) & $\begin{array}{c}-0.0164^{* * *} \\
(0.0044)\end{array}$ & $\begin{array}{c}-0.0196^{* * *} \\
(0.0043)\end{array}$ & $\begin{array}{c}-0.00743 \\
(0.0084)\end{array}$ & $\begin{array}{c}-0.00666 \\
(0.0079)\end{array}$ & $\begin{array}{c}-0.0217^{*} \\
(0.0124)\end{array}$ & $\begin{array}{c}-0.0161 \\
(0.0123)\end{array}$ & $\begin{array}{c}-0.0053 \\
(0.0116)\end{array}$ & $\begin{array}{c}0.00196 \\
(0.0107)\end{array}$ \\
\hline EV*Poor People (\%) & $\begin{array}{c}0.0134^{* * *} \\
(0.0047)\end{array}$ & & $\begin{array}{c}0.0176^{* *} \\
(0.0082)\end{array}$ & & $\begin{array}{c}0.0329^{* *} \\
(0.0134)\end{array}$ & & $\begin{array}{c}0.0438^{* * *} \\
(0.0119)\end{array}$ & \\
\hline Year $=1998 *$ Poor People $(\%)$ & $\begin{array}{c}-0.00262^{* *} \\
(0.0013)\end{array}$ & $\begin{array}{c}-0.00286^{* *} \\
(0.0013)\end{array}$ & $\begin{array}{c}0.0130^{* * *} \\
(0.0023)\end{array}$ & $\begin{array}{c}0.0125^{* * *} \\
(0.0023)\end{array}$ & $\begin{array}{c}-0.00891^{* * *} \\
(0.0027)\end{array}$ & $\begin{array}{c}-0.0113^{* * *} \\
(0.0026)\end{array}$ & $\begin{array}{c}-0.00368 \\
(0.0025)\end{array}$ & $\begin{array}{c}-0.00658^{* * *} \\
(0.0025)\end{array}$ \\
\hline Years of study & $\begin{array}{c}-0.0345^{* * *} \\
(0.0017)\end{array}$ & & $\begin{array}{c}-0.0367^{* * *} \\
(0.0027)\end{array}$ & & $\begin{array}{c}-0.00906^{* *} \\
(0.0036)\end{array}$ & & $\begin{array}{c}-0.0229^{* * * *} \\
(0.0034)\end{array}$ & \\
\hline EV $(98)^{*}$ Years of study & $\begin{array}{c}0.00325 \\
(0.0037)\end{array}$ & $\begin{array}{c}0.00217 \\
(0.0039)\end{array}$ & $\begin{array}{c}0.0190^{* *} \\
(0.0079)\end{array}$ & $\begin{array}{c}0.0215^{* * *} \\
(0.0073)\end{array}$ & $\begin{array}{c}0.0177 \\
(0.0109)\end{array}$ & $\begin{array}{c}0.0193^{*} \\
(0.0108)\end{array}$ & $\begin{array}{c}0.0102 \\
(0.0092)\end{array}$ & $\begin{array}{c}0.0104 \\
(0.0081)\end{array}$ \\
\hline $\mathrm{EV}^{*}$ Years of study & $\begin{array}{c}0.00800^{*} \\
(0.0043)\end{array}$ & & $\begin{array}{c}-0.00026 \\
(0.0074)\end{array}$ & & $\begin{array}{c}-0.00833 \\
(0.0120)\end{array}$ & & $\begin{array}{c}0.0221^{* *} \\
(0.0096)\end{array}$ & \\
\hline Year $=1998^{*}$ Years of study & $\begin{array}{c}-0.00176 \\
(0.0015)\end{array}$ & $\begin{array}{c}-0.00102 \\
(0.0015)\end{array}$ & $\begin{array}{c}-0.00583^{* *} \\
(0.0027)\end{array}$ & $\begin{array}{c}-0.00590^{* *} \\
(0.0027)\end{array}$ & $\begin{array}{c}-0.0111^{* * * *} \\
(0.0028)\end{array}$ & $\begin{array}{c}-0.00933^{* * *} \\
(0.0028)\end{array}$ & $\begin{array}{c}-0.00451^{*} \\
(0.0027)\end{array}$ & $\begin{array}{c}-0.00387 \\
(0.0027)\end{array}$ \\
\hline Constant & $\begin{array}{c}0.234^{* * * *} \\
(0.0077)\end{array}$ & $\begin{array}{c}0.217^{* * *} \\
(0.0061)\end{array}$ & $\begin{array}{c}0.258^{* * * *} \\
(0.0074)\end{array}$ & $\begin{array}{c}0.301^{* * *} \\
(0.0112)\end{array}$ & $\begin{array}{c}0.396^{* * *} \\
(0.0097)\end{array}$ & $\begin{array}{c}0.406^{* * *} \\
(0.0141)\end{array}$ & $\begin{array}{c}0.240^{* * *} \\
(0.0090)\end{array}$ & $\begin{array}{c}0.343^{* * *} \\
(0.0122)\end{array}$ \\
\hline Observations & 9375 & $\begin{array}{r}9375 \\
\text { Rob } \\
* \\
\text { (1) P }\end{array}$ & $\begin{array}{c}9375 \\
\text { andard er } \\
0.01, * *\end{array}$ & $\begin{array}{c}9375 \\
\text { in pare } \\
05,{ }^{*} \mathrm{p}\end{array}$ & ses 9375 & 9375 & 9375 & 9375 \\
\hline
\end{tabular}

Using average years of schooling, percentage of poor people, longevity HDI, inequality (Theil Index), children mortality, house infrastructure (telephone and electricity), percentage of woman, mayor party,mayor vote share on the last election, number of electors (as deviation from the threshold), state/municipality fixed effects,electors age composition (young and elderly), political engagement as controls

Breaking down the invalid votes between blank and spoiled, we are able to identify different aspects from the aggregated data on figures 13 and 14 bellow. The plots on the left of both figures represents the data while the ones on the right represents the same data for the 1998 election; both are plotted against an education covariate with the black dots representing municipalities that had electronic voting in $1998 .^{23}$ In general, the introduction of the new voting mechanism seems to cause a displacement on the share of these votes toward the $\mathrm{x}$ axis for the president, governor and Federal deputy office, but the intensity is not uniform among all offices. First, blank and spoiled votes display a different behavior even before the introduction of the electronic voting: the first is higher and disperse for all offices while the second has a lower rate for the executive offices. Second, as we can see on figure 11, for the president and the State governor election the introduction of the

\footnotetext{
${ }^{23}$ We use here the Census Data for average years of schooling among the city population. The variable is in standard values.
} 
electronic voting seems to have a positive impact on spoiled votes. As for the blank votes, the introduction of the new mechanism does not seem to have a strong impact on State deputy election.
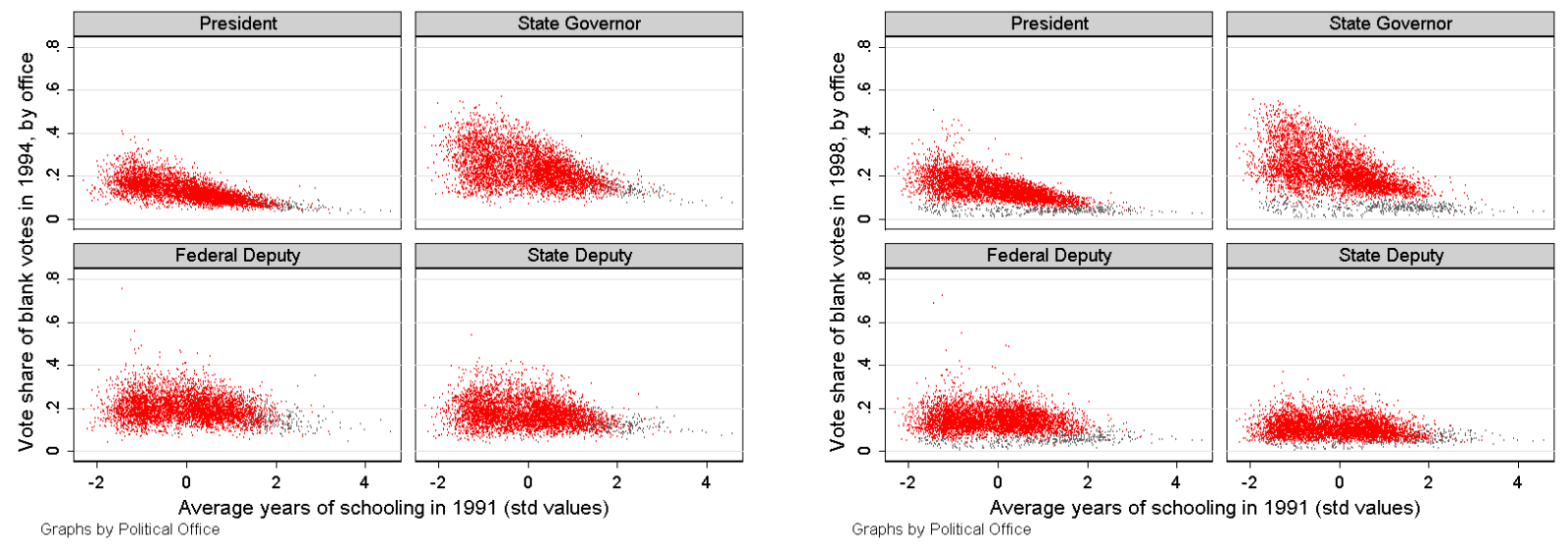

Figure 13: Blank Votes (black dots = electronic voting / left=1994; right=1998)
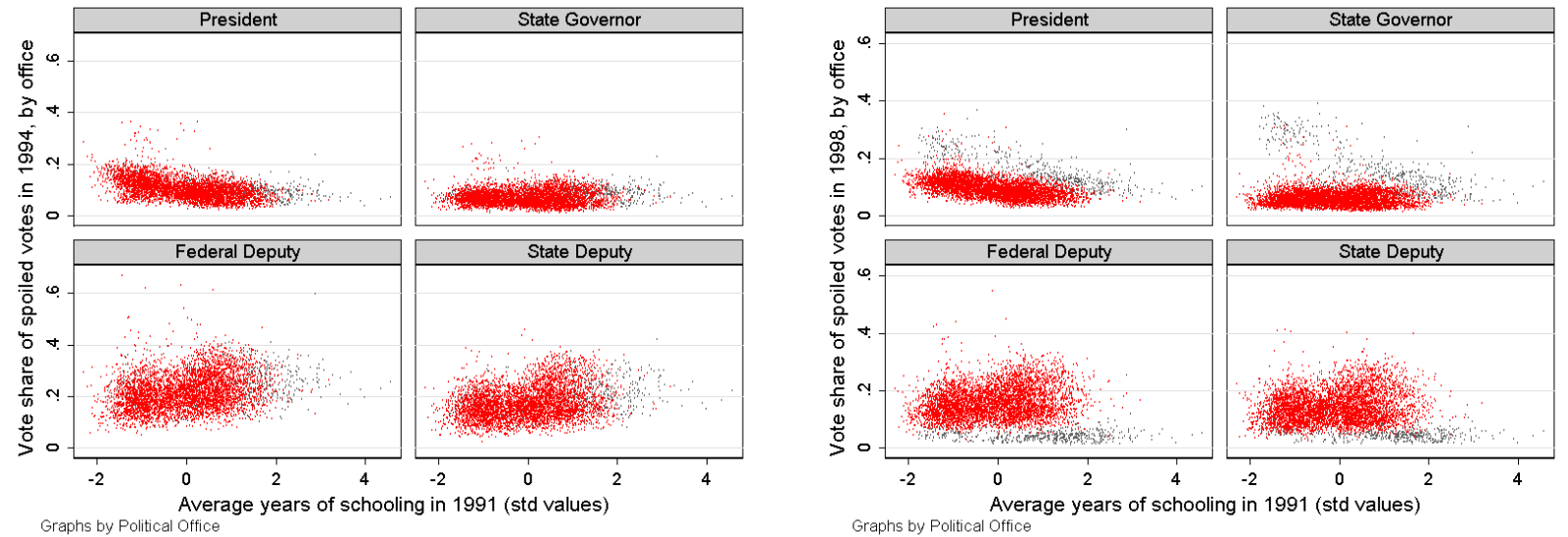

Figure 14: Spoiled Votes (black dots = electronic voting / left=1994; right=1998)

The patterns described above through a graphic analysis are corroborated by our statistic one. As it is displayed on table 6, the electronic voting has a negative and statistically significant impact on the blank vote share for all offices, being the State deputy election the less affected and the governor the most affected. As for the DRE dummy and education interaction, where it is significant, it follows the same behavior than the one stated before for invalid votes: higher education level leads to lower impact of the new voting technology for the legislative offices. Also we are able to identify the percentage of poor people as being an enhancer of the electronic voting effect.

Table 7 shows the results of the spoiled vote investigation and once again the graphical patterns are confirmed by the data analysis. First, on the opposite direction to the one 
Table 6: Electronic voting impact on Blank Votes

\begin{tabular}{|c|c|c|c|c|c|c|c|c|}
\hline Dep. Var.: Blank & \multicolumn{2}{|c|}{ President } & \multicolumn{2}{|c|}{ Governor } & \multicolumn{2}{|c|}{ Federal Deputy } & \multicolumn{2}{|c|}{ State Deputy } \\
\hline Regressions & (1) & $\overline{(2)}$ & (1) & (2) & (1) & (2) & (1) & (2) \\
\hline Electronic Voting (EV) & $\begin{array}{c}0.00159 \\
(0.0032)\end{array}$ & & $\begin{array}{c}0.00737 \\
(0.0079)\end{array}$ & & $\begin{array}{c}-0.0079 \\
(0.0079)\end{array}$ & & $\begin{array}{c}-0.0243^{* * *} \\
(0.0066)\end{array}$ & \\
\hline Year $=1998$ & $\begin{array}{c}0.0105^{* * *} \\
(0.0006)\end{array}$ & $\begin{array}{c}0.0119^{* * * *} \\
(0.0007)\end{array}$ & $\begin{array}{c}-0.0146^{* * * *} \\
(0.0012)\end{array}$ & $\begin{array}{c}-0.0115^{* * *} \\
(0.0012)\end{array}$ & $\begin{array}{c}-0.0515^{* * *} \\
(0.0009)\end{array}$ & $\begin{array}{c}-0.0492^{* * *} \\
(0.0010)\end{array}$ & $\begin{array}{c}-0.0657^{* * * *} \\
(0.0008)\end{array}$ & $\begin{array}{c}-0.0642^{* * * *} \\
(0.0008)\end{array}$ \\
\hline $\mathrm{EV}^{*}$ Year $=1998[\mathrm{EV}(98)]$ & $\begin{array}{c}-0.0932 * * * \\
(0.0045)\end{array}$ & $\begin{array}{c}-0.0928^{* * *} \\
(0.0048)\end{array}$ & $\begin{array}{c}-0.182^{* * *} \\
(0.0116)\end{array}$ & $\begin{array}{c}-0.179 * * * \\
(0.0114)\end{array}$ & $\begin{array}{c}-0.0850^{* * *} \\
(0.0086)\end{array}$ & $\begin{array}{c}-0.0863^{* * *} \\
(0.0089)\end{array}$ & $\begin{array}{c}-0.0336^{* * *} \\
(0.0079)\end{array}$ & $\begin{array}{c}-0.0316^{* * *} \\
(0.0079)\end{array}$ \\
\hline Poor People (\%) & $\begin{array}{c}0.0108^{* * *} \\
(0.0013)\end{array}$ & & $\begin{array}{c}-0.00652^{* * *} \\
(0.0021)\end{array}$ & & $\begin{array}{c}0.00615^{* * *} \\
(0.0021)\end{array}$ & & $\begin{array}{c}0.00273 \\
(0.0019)\end{array}$ & \\
\hline EV $(98) *$ Poor People $(\%)$ & $\begin{array}{c}-0.0125^{* * *} \\
(0.0035)\end{array}$ & $\begin{array}{c}-0.0151^{* * *} \\
(0.0034)\end{array}$ & $\begin{array}{c}-0.0368^{* * *} \\
(0.0077)\end{array}$ & $\begin{array}{c}-0.0364^{* * *} \\
(0.0076)\end{array}$ & $\begin{array}{c}-0.0432^{* * *} \\
(0.0073)\end{array}$ & $\begin{array}{c}-0.0429^{* * *} \\
(0.0072)\end{array}$ & $\begin{array}{c}-0.0314^{* * * *} \\
(0.0053)\end{array}$ & $\begin{array}{c}-0.0291^{* * *} \\
(0.0052)\end{array}$ \\
\hline EV*Poor People $(\%)$ & $\begin{array}{c}0.0119^{* * *} \\
(0.0030)\end{array}$ & & $\begin{array}{c}0.0157^{* *} \\
(0.0065)\end{array}$ & & $\begin{array}{c}0.0188^{* *} \\
(0.0075)\end{array}$ & & $\begin{array}{c}0.0248^{* * *} \\
(0.0050)\end{array}$ & \\
\hline Year $=1998^{*}$ Poor People $(\%)$ & $\begin{array}{c}-0.00742^{* * *} \\
(0.0012)\end{array}$ & $\begin{array}{c}-0.00720^{* * *} \\
(0.0012)\end{array}$ & $\begin{array}{c}0.0103^{* * *} \\
(0.0022)\end{array}$ & $\begin{array}{c}0.0105 * * * \\
(0.0022)\end{array}$ & $\begin{array}{c}-0.0110^{* * *} \\
(0.0018)\end{array}$ & $\begin{array}{c}-0.0122^{* * *} \\
(0.0018)\end{array}$ & $\begin{array}{c}-0.00579^{* * *} \\
(0.0014)\end{array}$ & $\begin{array}{c}-0.00771^{* * *} \\
(0.0014)\end{array}$ \\
\hline Years of study & $\begin{array}{c}-0.0222^{* * *} \\
(0.0013)\end{array}$ & & $\begin{array}{c}-0.0362 * * * \\
(0.0023)\end{array}$ & & $\begin{array}{c}-0.0109^{* * *} \\
(0.0022)\end{array}$ & & $\begin{array}{c}-0.0240^{* * *} \\
(0.0020)\end{array}$ & \\
\hline EV $(98)^{*}$ Years of study & $\begin{array}{c}0.0241^{* * *} * \\
(0.0030)\end{array}$ & $\begin{array}{c}0.0226^{* * *} \\
(0.0030)\end{array}$ & $\begin{array}{c}0.0292^{* * *} \\
(0.0067)\end{array}$ & $\begin{array}{c}0.0320^{* * *} \\
(0.0063)\end{array}$ & $\begin{array}{c}0.000424 \\
(0.0067)\end{array}$ & $\begin{array}{c}0.000587 \\
(0.0066)\end{array}$ & $\begin{array}{c}-0.00191 \\
(0.0045)\end{array}$ & $\begin{array}{c}-0.00189 \\
(0.0042)\end{array}$ \\
\hline $\mathrm{EV}^{*}$ Years of study & $\begin{array}{c}0.00516^{*} \\
(0.0029)\end{array}$ & & $\begin{array}{c}0.00129 \\
(0.0060)\end{array}$ & & $\begin{array}{c}-0.00314 \\
(0.0071)\end{array}$ & & $\begin{array}{c}0.0151^{* * *} \\
(0.0045)\end{array}$ & \\
\hline Year $=1998^{*}$ Years of study & $\begin{array}{c}-0.00715^{* * *} \\
(0.0013)\end{array}$ & $\begin{array}{c}-0.00552^{* * *} \\
(0.0014)\end{array}$ & $\begin{array}{c}-0.00631^{* *} \\
(0.0026)\end{array}$ & $\begin{array}{c}-0.00625^{* *} \\
(0.0027)\end{array}$ & $\begin{array}{c}-0.00654^{* * *} \\
(0.0019)\end{array}$ & $\begin{array}{c}-0.00468^{* *} \\
(0.0019)\end{array}$ & $\begin{array}{c}0.00344^{* *} \\
(0.0016)\end{array}$ & $\begin{array}{c}0.00416^{* * *} \\
(0.0016)\end{array}$ \\
\hline Constant & $\begin{array}{c}0.105^{* * *} \\
(0.0049)\end{array}$ & $\begin{array}{c}0.132^{* * *} \\
(0.0051)\end{array}$ & $\begin{array}{c}0.185^{* * *} \\
(0.0074)\end{array}$ & $\begin{array}{c}0.248^{* * *} \\
(0.0091)\end{array}$ & $\begin{array}{c}0.182^{* * *} \\
(0.0070)\end{array}$ & $\begin{array}{c}0.208^{* * *} \\
(0.0074)\end{array}$ & $\begin{array}{c}0.105^{* * *} \\
(0.0053)\end{array}$ & $\begin{array}{c}0.191^{* * *} \\
(0.0064)\end{array}$ \\
\hline Observations & 9375 & $\begin{array}{r}9375 \\
\text { Robus } \\
* * * \\
\text { (1) Po }\end{array}$ & $\begin{array}{c}9375 \\
\text { andard er } \\
0.01, * *\end{array}$ & $\begin{array}{l}9375 \\
\text { in paren } \\
5, * \mathrm{p}<\end{array}$ & $\begin{array}{l}9375 \\
\text { es }\end{array}$ & 9375 & 9375 & 9375 \\
\hline
\end{tabular}

Using average years of schooling, percentage of poor people, longevity HDI, inequality (Theil Index), children mortality, house infrastructure (telephone and electricity), percentage of woman, mayor party, mayor vote share on the last election, number of electors (as deviation from the threshold), state/municipality fixed effects,electors age composition (young and elderly), political engagement as controls

observed for invalid and blank votes, the introduction of electronic voting increases the share of spoiled votes for the executive offices (president and State governor) while the legislative offices follow the same reasoning as before. Moreover, although the interaction between the electronic voting indicator still reinforce the electronic voting impact the same is not observed for the interaction between the dummy and the percentage of poor people for the legislative offices. Both results came with great surprise since it was expected no difference between the types of invalid votes.

However, a more rigorous investigation on the differences between the paper ballot and the electronic voting mechanism may highlight the reasons for that. On the new mechanism side, the electronic voting has an explicit characteristic of making the voting process easier: once you learn how to use the machine, the process is the same for all offices - bottom of line, the elector has to press the number of the candidate or the party he has previously chosen. As for the old method, the paper ballot displays a heterogeneity among offices: as figure 1 shows, if you know how to read (numbers or words) voting for president and State governor required filling a check box, with an identification of all candidates. This was similar to bringing a cheat page to a test: you still have to think about your preferences, but once you are on the process of voting you can trust on the paper ballot information 
even if your mind went blank.

Table 7: Electronic voting impact on Spoiled Votes

\begin{tabular}{|c|c|c|c|c|c|c|c|c|}
\hline Dep. Var.: Spoiled & \multicolumn{2}{|c|}{ President } & \multicolumn{2}{|c|}{ Governor } & \multicolumn{2}{|c|}{ Federal Deputy } & \multicolumn{2}{|c|}{ State Deputy } \\
\hline Regressions & $\overline{(1)}$ & (2) & (1) & (2) & (1) & (2) & (1) & (2) \\
\hline Electronic Voting (EV) & $\begin{array}{c}0.000477 \\
(0.0040)\end{array}$ & & $\begin{array}{c}0.00594 \\
(0.0040)\end{array}$ & & $\begin{array}{c}-0.0066 \\
(0.0090)\end{array}$ & & $\begin{array}{c}-0.0165^{* *} \\
(0.0083)\end{array}$ & \\
\hline Year $=1998$ & $\begin{array}{c}-0.00799^{* * *} \\
(0.0005)\end{array}$ & $\begin{array}{c}-0.00760^{* * *} \\
(0.0005)\end{array}$ & $\begin{array}{c}-0.00911 * * * \\
(0.0003)\end{array}$ & $\begin{array}{c}-0.00841^{* * *} \\
(0.0004)\end{array}$ & $\begin{array}{c}-0.0561^{* * *} \\
(0.0009)\end{array}$ & $\begin{array}{c}-0.0546^{* * *} \\
(0.0009)\end{array}$ & $\begin{array}{c}-0.0287^{* * *} \\
(0.0008)\end{array}$ & $\begin{array}{c}-0.0274^{* * *} \\
(0.0009)\end{array}$ \\
\hline EV * Year $=1998[\mathrm{EV}(98)]$ & $\begin{array}{c}0.0472^{* * *} \\
(0.0052)\end{array}$ & $\begin{array}{c}0.0544^{* * *} \\
(0.0052)\end{array}$ & $\begin{array}{c}0.0658^{* * *} \\
(0.0070)\end{array}$ & $\begin{array}{c}0.0636^{* * *} \\
(0.0071)\end{array}$ & $\begin{array}{c}-0.136^{* * *} \\
(0.0110)\end{array}$ & $\begin{array}{c}-0.140^{* * *} \\
(0.0129)\end{array}$ & $\begin{array}{c}-0.0897^{* * *} \\
(0.0096)\end{array}$ & $\begin{array}{c}-0.0923^{* * *} \\
(0.0109)\end{array}$ \\
\hline Poor People (\%) & $\begin{array}{c}-0.00164^{*} \\
(0.0009)\end{array}$ & & $\begin{array}{c}-0.00194^{* * *} \\
(0.0007)\end{array}$ & & $\begin{array}{c}-0.00885^{* * *} \\
(0.0022)\end{array}$ & & $\begin{array}{c}-0.00775^{* * *} \\
(0.0019)\end{array}$ & \\
\hline EV $(98) *$ Poor People $(\%)$ & $\begin{array}{c}-0.00391 \\
(0.0045)\end{array}$ & $\begin{array}{c}-0.00448 \\
(0.0042)\end{array}$ & $\begin{array}{c}0.0294^{* * *} \\
(0.0060)\end{array}$ & $\begin{array}{c}0.0298^{* * *} \\
(0.0058)\end{array}$ & $\begin{array}{c}0.0216^{* *} \\
(0.0093)\end{array}$ & $\begin{array}{c}0.0268^{* * *} \\
(0.0091)\end{array}$ & $\begin{array}{c}0.0261^{* * *} \\
(0.0088)\end{array}$ & $\begin{array}{c}0.0311^{* * *} \\
(0.0082)\end{array}$ \\
\hline $\mathrm{EV}^{*}$ Poor People (\%) & $\begin{array}{c}0.00144 \\
(0.0032)\end{array}$ & & $\begin{array}{c}0.00194 \\
(0.0035)\end{array}$ & & $\begin{array}{c}0.0140^{*} \\
(0.0085)\end{array}$ & & $\begin{array}{c}0.0191^{* *} \\
(0.0081)\end{array}$ & \\
\hline Year $=1998 *$ Poor People $(\%)$ & $\begin{array}{c}0.00480^{* * *} \\
(0.0008)\end{array}$ & $\begin{array}{c}0.00434^{* * *} \\
(0.0008)\end{array}$ & $\begin{array}{c}0.00270^{* * *} \\
(0.0006)\end{array}$ & $\begin{array}{c}0.00203^{* * *} \\
(0.0006)\end{array}$ & $\begin{array}{c}0.00207 \\
(0.0017)\end{array}$ & $\begin{array}{c}0.000986 \\
(0.0017)\end{array}$ & $\begin{array}{c}0.0021 \\
(0.0016)\end{array}$ & $\begin{array}{c}0.00113 \\
(0.0016)\end{array}$ \\
\hline Years of study & $\begin{array}{c}-0.0124^{* * *} \\
(0.0010)\end{array}$ & & $\begin{array}{c}-0.000515 \\
(0.0008)\end{array}$ & & $\begin{array}{c}0.00187 \\
(0.0022)\end{array}$ & & $\begin{array}{c}0.00111 \\
(0.0019)\end{array}$ & \\
\hline EV $(98)^{*}$ Years of study & $\begin{array}{c}-0.0208^{* * *} \\
(0.0033)\end{array}$ & $\begin{array}{c}-0.0204^{* * *} \\
(0.0033)\end{array}$ & $\begin{array}{c}-0.0102^{* *} \\
(0.0051)\end{array}$ & $\begin{array}{c}-0.0105^{* *} \\
(0.0047)\end{array}$ & $\begin{array}{c}0.0173^{* *} \\
(0.0076)\end{array}$ & $\begin{array}{c}0.0187^{* * *} \\
(0.0072)\end{array}$ & $\begin{array}{c}0.0121^{*} \\
(0.0070)\end{array}$ & $\begin{array}{c}0.0123^{* *} \\
(0.0062)\end{array}$ \\
\hline $\mathrm{EV}^{*}$ Years of study & $\begin{array}{c}0.00284 \\
(0.0027)\end{array}$ & & $\begin{array}{c}-0.00155 \\
(0.0030)\end{array}$ & & $\begin{array}{c}-0.00519 \\
(0.0071)\end{array}$ & & $\begin{array}{c}0.00698 \\
(0.0065)\end{array}$ & \\
\hline Year $=1998^{*}$ Years of study & $\begin{array}{c}0.00539^{* * *} \\
(0.0010)\end{array}$ & $\begin{array}{c}0.00450^{* * *} \\
(0.0010)\end{array}$ & $\begin{array}{c}0.000477 \\
(0.0007)\end{array}$ & $\begin{array}{c}0.000357 \\
(0.0007)\end{array}$ & $\begin{array}{c}-0.00461^{* * *} \\
(0.0018)\end{array}$ & $\begin{array}{c}-0.00465^{* * *} \\
(0.0017)\end{array}$ & $\begin{array}{c}-0.00795^{* * *} \\
(0.0016)\end{array}$ & $\begin{array}{c}-0.00803^{* * *} \\
(0.0016)\end{array}$ \\
\hline Constant & $\begin{array}{c}0.129^{* * *} \\
(0.0064) \\
\end{array}$ & $\begin{array}{c}0.0840^{* * *} \\
(0.0053)\end{array}$ & $\begin{array}{c}0.0728^{* * *} \\
(0.0035)\end{array}$ & $\begin{array}{c}0.0534^{* * *} \\
(0.0065)\end{array}$ & $\begin{array}{c}0.214^{* * *} \\
(0.0064) \\
\end{array}$ & $\begin{array}{c}0.198^{* * *} \\
(0.0108)\end{array}$ & $\begin{array}{c}0.135 * * * \\
(0.0050) \\
\end{array}$ & $\begin{array}{c}0.153^{* * *} \\
(0.0087)\end{array}$ \\
\hline Observations & 9375 & 9375 & 9375 & 9375 & 9375 & 9375 & 9375 & 9375 \\
\hline
\end{tabular}

Using average years of schooling, percentage of poor people, longevity HDI, inequality (Theil Index), children mortality, house infrastructure (telephone and electricity), percentage of woman, mayor party, mayor vote share on the last election, number of electors (as deviation from the threshold), state/municipality fixed effects,electors age composition (young and elderly), political engagement as controls

For that reason, we believe that the electronic system had a positive impact on spoiled votes for these offices: since both of them already had low rates of voting mistakes, electors with higher propensity of spoiling his vote were benefited by the paper ballot list of candidates, what we could call a memory effect. Table 16 displays the impact of the DRE on the percentage of electors that actually voted in the elections (i.e., turnout divided by total electors). We find robust evidence that the new mechanism reduced turnout, revealing that perhaps voters' trust in the new system was not achieved in this first election.

Summing up, when we analyze spoiled votes on legislative offices and blank votes for all offices, the overall conclusion we can extract from the results is: with little effort, the use of the DRE created a striking political change by reducing invalid votes, allowing millions of electors to express their political preferences. As observed on table 7 the impact on spoiled votes for Federal mounts up to more than 15\% which, considering the number of electors in cities with electronic voting, is equivalent to almost 10 million electors. Most of these results are corroborated in our robustness checks, though some of the impacts of the interactions of the electronic voting and covariates do not remain statiscally significant 
(see Appendix 3.1 for further details).

Figure 15 summarizes all of results we described by displaying the impacts of each variable, whenever significant, associated with a color: red scale represents negative impacts and blue the positive ones. It displays the same results of the statistics table, but it allows us to visualize the complexity of the determinants of invalid votes and turnout ratios. Specifically, it demonstrated the possibility of competing theories for the invalid votes determinants, as in Power e Garand (2007), Power e Roberts (1995), Katz (2011). For instance, it is prominent the concomitant negative influence of percentage of young electors and political engagement on vote alienation with the fact that both are not the channel through which the electronic voting affects this vote characteristic. The same cannot be affirmed in relation to the average years of schooling: though it affects negatively invalid votes and blank votes, it does not for the share spoiled votes on every office election.

Figure 15: Summary - Electronic voting impact on invalid votes $(P$ - president; $G$ governor; F - Federal deputy; S - State deputy)

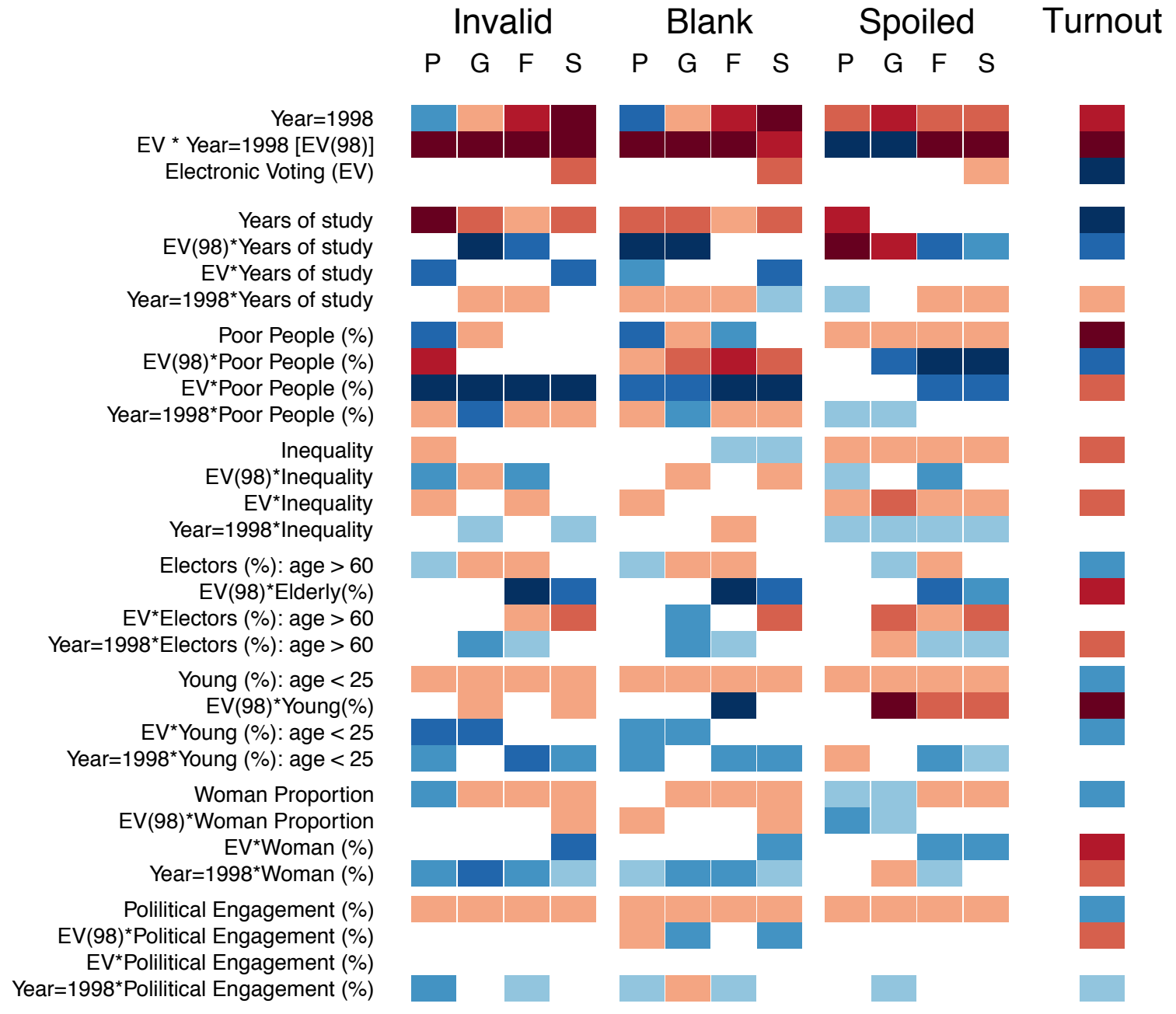




\subsection{Political Competition}

\subsubsection{Party Code Votes and Fractionalization}

However, once we find a significant enfranchising effect we enter a new area of investigation (and perhaps more important) which is the distribution of this "new" electors. As we posed before, does this increase in vote count make results in a maintenance of the status quo or does it change the elections outcome? Since the evidence indicates an increase of valid votes it is natural to investigate the distribution of this growth. When we addressed to this question before one of the issues mentioned was the difference between candidate vote and party vote for the legislative offices. As we mentioned in subsection A of section I, the possibility of choosing a party and not a specific candidate is particularly important when we consider the electoral rule that distributes the available seats to the candidates and party. As explained before, a party can have a strong candidate and receive no seat (because the party as whole does not achieve a minimum number of votes) while a bigger party with "small" candidates can have enough votes to elect them all. That is why party votes are so important for the legislative election since it becomes an alternative to strong candidates.

Table 8 bellow shows that the increase in valid votes had a common characteristic of being concentrated on party code votes and the poor the city the greater the impact on party vote. $^{24}$ In the end, this suggest that parties left this election stronger in relation to the candidates on treated municipalities, being able to capitalize the voting system change on their behalf. An increase of $13 \%$ for Federal deputy and an impact of $12 \%$ for the State deputy office represents almost the double of party vote codes that this municipalities had before the adoption of a new voting mechanism (considering an average of $12 \%$ for Federal deputy and $11 \%$ for State deputy of party code votes in 1994 - Table 2).

This was the result not only from the mitigation of the obstacles associated with the paper ballot voting, but also by the fact that the electronic voting defined a specific voting order and made obliged the elector to actually make a choice for every single office (for instance, in the paper ballot blank votes could be interpreted both as a choice or as an incapacity of the elector to fulfill that task - writing his choice). Several critics of the chosen order advocate that it is common to hear that voters choose party code vote for the legislative offices thinking they are actually voting for president and governor(TOLEDO, 2010). We are unable to test the probability of a particular elector choosing the same party for both

\footnotetext{
${ }^{24}$ Though the result associated with poor cities is not sustained by our robustness checks with municipalities around the threshold. Nonetheless, we find then that education reduces the same impact.
} 
Table 8: Electronic voting impact on Party Votes

\begin{tabular}{|c|c|c|c|c|}
\hline Dep. Var.: Party Vote & \multicolumn{2}{|c|}{ Federal Deputy } & \multicolumn{2}{|c|}{ State Deputy } \\
\hline Regressions & (1) & (2) & (1) & (2) \\
\hline Electronic Voting (EV) & $\begin{array}{c}-0.00107 \\
(0.0068)\end{array}$ & & $\begin{array}{c}-0.00482 \\
(0.0060)\end{array}$ & \\
\hline Year $=1998$ & $\begin{array}{c}0.0147^{* * *} \\
(0.0006)\end{array}$ & $\begin{array}{c}0.0155^{* * *} \\
(0.0006)\end{array}$ & $\begin{array}{c}0.0144^{* * *} \\
(0.0005)\end{array}$ & $\begin{array}{c}0.0147^{* * *} \\
(0.0006)\end{array}$ \\
\hline EV * Year $=1998[\mathrm{EV}(98)]$ & $\begin{array}{c}0.115^{* * *} \\
(0.0116)\end{array}$ & $\begin{array}{c}0.129^{* * *} \\
(0.0124)\end{array}$ & $\begin{array}{c}0.165^{* * *} \\
(0.0096)\end{array}$ & $\begin{array}{c}0.174^{* * *} \\
(0.0099)\end{array}$ \\
\hline Poor People (\%) & $\begin{array}{c}-0.00874^{* * *} \\
(0.0012)\end{array}$ & & $\begin{array}{c}-0.00774^{* * *} \\
(0.0011)\end{array}$ & \\
\hline EV(98)*Poor People (\%) & $\begin{array}{c}0.0401 * * * \\
(0.0088)\end{array}$ & $\begin{array}{c}0.0452^{* * *} \\
(0.0084)\end{array}$ & $\begin{array}{c}0.0188^{* * *} \\
(0.0070)\end{array}$ & $\begin{array}{c}0.0239 * * * \\
(0.0069)\end{array}$ \\
\hline EV*Poor People (\%) & $\begin{array}{c}-0.0338^{* * *} \\
(0.0091)\end{array}$ & & $\begin{array}{c}-0.0271^{* * *} \\
(0.0086)\end{array}$ & \\
\hline Year $=1998 *$ Poor People $(\%)$ & $\begin{array}{c}0.00599 * * * \\
(0.0011)\end{array}$ & $\begin{array}{c}0.00532^{* * *} \\
(0.0011)\end{array}$ & $\begin{array}{c}0.00868^{* * *} \\
(0.0010)\end{array}$ & $\begin{array}{c}0.00846^{* * *} \\
(0.0010)\end{array}$ \\
\hline Years of study & $\begin{array}{c}0.00583^{* * *} \\
(0.0013)\end{array}$ & & $\begin{array}{c}0.00454^{* * *} \\
(0.0011)\end{array}$ & \\
\hline EV $(98)^{*}$ Years of study & $\begin{array}{c}0.0139^{*} \\
(0.0073)\end{array}$ & $\begin{array}{c}0.0167^{* *} \\
(0.0065)\end{array}$ & $\begin{array}{c}-0.0107^{*} \\
(0.0060)\end{array}$ & $\begin{array}{c}-0.00797 \\
(0.0054)\end{array}$ \\
\hline $\mathrm{EV}^{*}$ Years of study & $\begin{array}{c}-0.0357^{* * *} \\
(0.0077)\end{array}$ & & $\begin{array}{c}-0.0230 * * * \\
(0.0073)\end{array}$ & \\
\hline Year $=1998^{*}$ Years of study & $\begin{array}{c}-0.00403^{* * *} \\
(0.0011)\end{array}$ & $\begin{array}{c}-0.00430 * * * \\
(0.0011)\end{array}$ & $\begin{array}{c}-0.00178^{*} \\
(0.0009)\end{array}$ & $\begin{array}{c}-0.00214^{* *} \\
(0.0009)\end{array}$ \\
\hline Constant & $\begin{array}{c}0.0457^{* * *} \\
(0.0035)\end{array}$ & $\begin{array}{c}0.0422^{* * *} \\
(0.0081)\end{array}$ & $\begin{array}{c}0.0244^{* * *} \\
(0.0026)\end{array}$ & $\begin{array}{c}0.0332^{* * *} \\
(0.0071)\end{array}$ \\
\hline $\begin{array}{r}\text { Robi } \\
* * \\
\text { (1) } \mathrm{P}\end{array}$ & $\begin{array}{c}9375 \\
\text { tandard el } \\
0.01, * * \\
\text { regressio }\end{array}$ & $\begin{array}{c}9375 \\
\text { in parent } \\
.05, * \mathrm{p}<0 \\
\text { 2) Fixed } \mathrm{F}\end{array}$ & $\begin{array}{l}9375 \\
\text { es } \\
\text { ets }\end{array}$ & 9375 \\
\hline
\end{tabular}

Using average years of schooling, percentage of poor people, longevity HDI, inequality (Theil Index), children mortality, house infrastructure (telephone and electricity), percentage of woman, mayor party, mayor vote share on the last election, number of electors (as deviation from the threshold), state/municipality fixed effects, electors age composition (young and elderly), political engagement as controls

legislative elections. Nonetheless, we discuss ahead the impact of the electronic voting in the probability of finding votes for the major parties in the president and deputies elections.

However, the increase of party code votes itself cannot be literally translated into a change on the vote structure. To analyze that, we use the vote fractionalization to identify if this increase is resulting on a change in the vote distribution status quo. As described before, we employ a measure of heterogeneity based on a decreasing transformation of the Herfindahl concentration index. Largely employed as measure of market concentration, the index provides a good proxy for the level of competition in the municipalities: in cities with bigger political competition (greater vote dispersion among candidates) the index increases toward one. Therefore, if electronic voting has a positive impact on our index this can be translated as a decentralization of the vote share, meaning that the big parties are loosing vote share to smaller ones in these municipalities. ${ }^{25}$

That is precisely what the table 9 suggests: electronic voting results in vote pulverization

\footnotetext{
${ }^{25}$ Obviously, this does not necessarily mean that the biggest party is loosing to the smallest one but it shows that the vote share distribution is more equally between parties
} 
Table 9: Electronic voting impact on Party Fractionalization

\begin{tabular}{|c|c|c|c|c|c|c|c|c|}
\hline Dep. Var.: Fractionalization (party) & Pres & dent & Gove & rnor & Federal & Deputy & State & Deputy \\
\hline Regressions & (1) & (2) & (1) & (2) & (1) & (2) & (1) & (2) \\
\hline Electronic Voting (EV) & $\begin{array}{c}0.0162 \\
(0.0954)\end{array}$ & & $\begin{array}{c}0.258^{*} \\
(0.1390)\end{array}$ & & $\begin{array}{c}-0.0807 \\
(0.1580)\end{array}$ & & $\begin{array}{c}-0.0238 \\
(0.1350)\end{array}$ & \\
\hline Year $=1998$ & $\begin{array}{c}-0.0462^{* * *} \\
(0.0172)\end{array}$ & $\begin{array}{c}-0.0606^{* * *} \\
(0.0185)\end{array}$ & $\begin{array}{c}0.0259 \\
(0.0195)\end{array}$ & $\begin{array}{c}0.0727^{* * *} \\
(0.0213)\end{array}$ & $\begin{array}{c}-0.199 * * * \\
(0.0488)\end{array}$ & $\begin{array}{c}-0.210^{* * *} \\
(0.0521)\end{array}$ & $\begin{array}{c}-0.130^{* *} \\
(0.0600)\end{array}$ & $\begin{array}{c}-0.168^{* * *} \\
(0.0641)\end{array}$ \\
\hline EV $*$ Year $=1998[\mathrm{EV}(98)]$ & $\begin{array}{c}-0.288^{*} \\
(0.1630)\end{array}$ & $\begin{array}{l}-0.275 \\
(0.1760)\end{array}$ & $\begin{array}{c}-0.408^{* *} \\
(0.2000)\end{array}$ & $\begin{array}{c}-0.389^{*} \\
(0.2240)\end{array}$ & $\begin{array}{c}1.011^{* * *} \\
(0.1880)\end{array}$ & $\begin{array}{c}0.884^{* * *} \\
(0.2080)\end{array}$ & $\begin{array}{c}0.572^{* * *} \\
(0.1750)\end{array}$ & $\begin{array}{c}0.538^{* * *} \\
(0.1980)\end{array}$ \\
\hline Poor People (\%) & $\begin{array}{c}0.0932^{* * *} \\
(0.0323)\end{array}$ & & $\begin{array}{c}0.304^{* * *} \\
(0.0339)\end{array}$ & & $\begin{array}{c}-0.103^{* * *} \\
(0.0396)\end{array}$ & & $\begin{array}{c}-0.147^{* * *} \\
(0.0394)\end{array}$ & \\
\hline EV $(98)^{*}$ Poor People (\%) & $\begin{array}{c}0.0632 \\
(0.1070)\end{array}$ & $\begin{array}{c}0.0782 \\
(0.1140)\end{array}$ & $\begin{array}{c}-0.387^{* * *} \\
(0.1450)\end{array}$ & $\begin{array}{c}-0.380^{* *} \\
(0.1480)\end{array}$ & $\begin{array}{c}0.0429 \\
(0.1520)\end{array}$ & $\begin{array}{c}-0.0558 \\
(0.1640)\end{array}$ & $\begin{array}{c}-0.351^{* *} \\
(0.1430)\end{array}$ & $\begin{array}{c}-0.443^{* * *} \\
(0.1560)\end{array}$ \\
\hline $\mathrm{EV}^{*}$ Poor People $(\%)$ & $\begin{array}{c}-0.0612 \\
(0.0857)\end{array}$ & & $\begin{array}{c}0.246^{* *} \\
(0.1130)\end{array}$ & & $\begin{array}{c}-0.0536 \\
(0.1260)\end{array}$ & & $\begin{array}{c}0.0751 \\
(0.1140)\end{array}$ & \\
\hline Year $=1998^{*}$ Poor People $(\%)$ & $\begin{array}{c}0.298^{* * *} \\
(0.0327)\end{array}$ & $\begin{array}{c}0.291^{* * *} \\
(0.0328)\end{array}$ & $\begin{array}{c}-0.307^{* * * *} \\
(0.0362)\end{array}$ & $\begin{array}{c}-0.328^{* * *} \\
(0.0371)\end{array}$ & $\begin{array}{c}0.233^{* * *} \\
(0.0452)\end{array}$ & $\begin{array}{c}0.179 * * * \\
(0.0464)\end{array}$ & $\begin{array}{c}0.285^{* * *} \\
(0.0467)\end{array}$ & $\begin{array}{c}0.224^{* * * *} \\
(0.0471)\end{array}$ \\
\hline Years of study & $\begin{array}{c}0.370^{* * *} \\
(0.0329)\end{array}$ & & $\begin{array}{c}0.159^{* * *} \\
(0.0353)\end{array}$ & & $\begin{array}{c}-0.0239 \\
(0.0399)\end{array}$ & & $\begin{array}{c}-0.0758^{*} \\
(0.0431)\end{array}$ & \\
\hline $\mathrm{EV}(98)^{*}$ Years of study & $\begin{array}{c}-0.0911 \\
(0.1040)\end{array}$ & $\begin{array}{c}-0.0645 \\
(0.1050)\end{array}$ & $\begin{array}{l}-0.164 \\
(0.1550)\end{array}$ & $\begin{array}{l}-0.172 \\
(0.1560)\end{array}$ & $\begin{array}{c}-0.142 \\
(0.1340)\end{array}$ & $\begin{array}{c}-0.0928 \\
(0.1430)\end{array}$ & $\begin{array}{l}-0.206 \\
(0.1300)\end{array}$ & $\begin{array}{l}-0.172 \\
(0.1380)\end{array}$ \\
\hline $\mathrm{EV}^{*}$ Years of study & $\begin{array}{c}-0.0983 \\
(0.0718)\end{array}$ & & $\begin{array}{c}0.00806 \\
(0.1120)\end{array}$ & & $\begin{array}{l}-0.167 \\
(0.1090)\end{array}$ & & $\begin{array}{l}-0.115 \\
(0.1050)\end{array}$ & \\
\hline Year $=1998^{*}$ Years of study & $\begin{array}{c}0.139^{* * *} \\
(0.0355)\end{array}$ & $\begin{array}{c}0.161^{* * *} \\
(0.0353)\end{array}$ & $\begin{array}{c}-0.00791 \\
(0.0399)\end{array}$ & $\begin{array}{c}0.0167 \\
(0.0402)\end{array}$ & $\begin{array}{c}0.382^{* * *} \\
(0.0492)\end{array}$ & $\begin{array}{c}0.362^{* * *} \\
(0.0496)\end{array}$ & $\begin{array}{c}0.410^{* * *} \\
(0.0508)\end{array}$ & $\begin{array}{c}0.397^{* * *} \\
(0.0513)\end{array}$ \\
\hline \# of parties & - & - & $\begin{array}{c}0.0201^{* *} \\
(0.0094)\end{array}$ & $\begin{array}{c}0.0172^{*} \\
(0.0097)\end{array}$ & $\begin{array}{c}0.0131^{*} \\
(0.0067)\end{array}$ & $\begin{array}{c}0.01 \\
(0.0070)\end{array}$ & $\begin{array}{c}0.00291 \\
(0.0079)\end{array}$ & $\begin{array}{c}0.00645 \\
(0.0083)\end{array}$ \\
\hline Constant & $\begin{array}{c}0.854^{* * *} \\
(0.1580)\end{array}$ & $\begin{array}{c}0.00296 \\
(0.1410)\end{array}$ & $\begin{array}{c}0.249^{* *} \\
(0.1170)\end{array}$ & $\begin{array}{r}-0.271 \\
(0.1830) \\
\end{array}$ & $\begin{array}{c}0.578^{* * *} \\
(0.1900)\end{array}$ & $\begin{array}{l}0.283 \\
(0.2640) \\
\end{array}$ & $\begin{array}{c}0.813^{* * *} \\
(0.1810)\end{array}$ & $\begin{array}{l}0.247 \\
(0.2720)\end{array}$ \\
\hline Observations & 9375 & 9375 & 9375 & 9375 & 9358 & 9358 & 9342 & 9342 \\
\hline
\end{tabular}

(1) Pooled regression; (2) Fixed Effects

Using average years of schooling, percentage of poor people, longevity HDI, inequality (Theil Index), children mortality, house infrastructure (telephone and electricity), percentage of woman, mayor party, mayor vote share on the last election, number of electors (as deviation from the threshold), state/municipality fixed effects,electors age composition (young and elderly), political engagement as controls

for party code votes on legislative offices, since it has a positive and significant impact on fractionalization. ${ }^{26}$ Deputy election in cities that used electronic voting have an statistically and economically significant impact of approximately one standard deviation on the Herfindahl average for party code vote share. This means that besides increasing the party code vote share, the DRE affects it the distribution among the parties, making it less concentrated. Furthermore, the distribution is positively (and significant) related to education where the electronic voting was adopted: the results suggest that, though it increases the party code vote share, it helps to break vote oligopolies and this effect is higher in places where education is higher.

We run the same analysis for candidates vote fractionalization, i.e., considering the distribution of votes for State and Federal legislative offices between candidates. As table 17 shows, the impact of electronic voting on candidate fractionalization is also significant for

\footnotetext{
${ }^{26}$ The effect is negative for the State governor office, suggesting that there is in fact a concentration of votes for this in municipalities that adopted the electronic voting. However, it is only marginally significant. We control for the number of parties in order to avoid to account a vote dispersion caused by more competitors as a result of electors' preferences.
} 
Federal deputy, but smaller than the fractionalization of party code votes. ${ }^{27}$ Summing up, we identify an increase in political competition translated by two factors so far: i) increase of party code vote share, meaning that parties left the election stronger in cities where the electronic voting was adopted (and with an expectation of become even stronger with the electronic voting being extended to all municipalities); ii) increase of vote dispersion, especially in party code votes.

\subsubsection{Candidates and Party performance}

We also analyze whether this change in political competition, expressed by an increase in vote dispersion, affected candidates and parties performance. As mentioned before, we use a "best loser" classification, constructed in order to assign only one candidate as "best loser" the of each city, respecting the restriction that, among the cities that he's characterized as so, the candidates are chosen to be the "best loser" for the most important city for his election performance (i.e., the one the represents the bigger vote share of that candidate among the ones that he's classified as best loser). What lies behind this characterization is the idea that legislative candidates who had an expressive vote performance but were not elected are considered possible candidates for the mayor election held two years later. Table 18 shows that electronic voting does not have a statistically significant impact on these candidates performance nor affects their probability of running for mayor.

Since "best loser" that are federal deputies could act differently than State deputies, we construct the same indicator considering only State deputies candidates. Again, table 19 shows electronic voting appears to have a small, and marginally significant, impact on these candidates performance. This impact does not survive to our robustness check using the sample around the discontinuity threshold (see table 48). ${ }^{28}$

In order to ascertain whether this change benefited any of the Brazilian major parties, we ran an analysis of the impact of the electronic voting adoption for PSDB, PMDB, PT and PFL vote share in all offices. Table 20-23 shows the change in the voting mechanism do affects the parties and offices differently. On the negative side, PT and PMDB seems to lose vote share with the new voting technology: the first in all elections but the State governor one (for both deputy elections, a significant loss between 6\%-7\%) and the latter

\footnotetext{
${ }^{27}$ The results are not confirmed when we investigate only the municipalities around the threshold (see table 47.

${ }^{28}$ Although we cannot find impact on the "best loser" performance it is interesting to notice that "best losers" have a better performance, caeteris paribus, when they belong to the incumbent mayor party.
} 
only in the legislative' ones (a loss between 7\%-8\%). ${ }^{29}$ PSDB loses around 5\% with introduction of the electronic voting in the Federal deputy election, but this impact is soften by the interaction between DRE and years of schooling. ${ }^{30}$ As votes do not vanish and none of the 4 big parties analyzed received the total loss in the legislative election experienced by the others, this imply that other smaller parties must have been benefited by the new technology, increasing their party code vote share on legislative elections (corroborating the result on party code vote fractionalization).

\section{The Mayor Party}

An important historical fact associated with the elections of 1998 was that PSDB, holding the presidential office since 1996, successfully approved the re-election law in 1997 which allowed the party president, Fernando Henrique Cardoso (the incumbent president) to run in the 1998 election as well as all incumbents of the executive offices. Because of this new possibility (re-election), we also analyze whether the party of the incumbent mayor benefited from the new voting mechanism (that is, if the mayor puts additional effort to support his party in the elections because he now has the possibility of being reelected). The results displayed on table 24 is that the electronic voting does not exerts a significant influence on the mayor party performance, unless for the State governor office. This finding shows that if electronic voting alter political competition in the legislative election in municipalities, this change, on average, is not appropriated by the incumbent mayor and, as a consequence, could signal, for the incumbent mayor, an increase in the political competition. ${ }^{31}$

Table 25 shows the same investigation considering just party code votes. Again, we find no impact of the electronic voting on the mayor party performance. Nonetheless, we find negative and significant impact on cities governed by PT the State legislative elections (meaning that cities governed by this party not only we unable to capture the party code vote increase as they were negatively affected by it). We also investigate if specific parties were benefited by the electronic voting by regressing the mayor party performance against the interaction of the electronic voting in 1998 and a dummy for each mayor party. We

\footnotetext{
${ }^{29}$ Given our context of increase in party code vote share, this means the these parties were unable to take advantage of the new vote pattern.

${ }^{30}$ We are unable to identify any direct significant impact of the new voting procedure on PFL, although the party seems to lose vote among the poorest municipalities on the treatment group.

${ }^{31}$ We analyzed the performance of the mayor party in both presidential and State governor elections. For the first one, we find no impact of the new technology. For the second, we find a strong positive impact when the parties of the governor and the mayor match, supported by the robustness check, suggesting a strong relation between local political actors and the state government. Nonetheless, we understand that this investigation could be biased since municipalities would be misrepresented because we do not have a president or State governor candidate for every mayor party.
} 
find no significant evidence that the new technology affected parties differently.

\section{Final results on party performance}

As a final analysis we run a series of test to investigate the major parties performance as a whole, testing whether the electronic voting affected the probability of finding votes for the same party for the offices. Table 26 shows that the new mechanism seems to have no direct a direct impact on choosing PT or PSDB for the legislative offices and the presidential one. Table 27 displays the same analysis only for the legislative offices, where we also investigate the performance of PMDB. In this case, the electronic voting has a positive impact on PSDB performance meaning that the electronic voting made more likely to choose PSDB on both legislative offices considering the party code vote distribution. ${ }^{32}$

Tables 28-31 presents the results of the analysis of the impact of the electronic voting on the odds of choosing PT or PSDB for one of the legislative offices over choosing the same party for the president office. Here, we find evidence that the electronic voting reduced the odds of choosing the PSDB party code for Federal deputy and had no effect on the odds of choosing PT party code, over their president candidate. However, it had a positive influence on the odds of choosing a PT legislative candidate of PT over the probability of choosing the PT's president candidate in cities that adopted the new voting mechanism (perhaps because of the negative effect on PT president candidate, as seen on table 20).

\subsection{Paper Ballot Impact}

In table 10 we present a straightforward way to estimate the association between the use of paper ballot and the share of the officially recorded votes for the bookend candidates (the ones placed near strong candidates on the paper ballot). We compare the performance of the candidates positioned in front of and behind the two major candidates ("book" candidates are Luiz Inácio Lula da Silva and Fernando Henrique Cardoso - henceforth, Lula and FHC) on all paper ballots in municipalities that adopted the electronic voting (where, naturally, this positions should not matter) with the ones that did not. First, as expected for the president office being in a municipality with paper ballot is better than being in one with electronic voting. The reason is the same we pointed when analyzing blank votes: the paper ballot helps the elector to remember the candidates that are running for that office. We also identify that this impact is lessen by higher education

\footnotetext{
${ }^{32}$ This result is not observed when we use the sample around the discontinuity, as shown by table 57 . However, in this case the impact for PMDB and PT are negative and significant.
} 
level.

Second, our findings also suggest that being placed near strong candidates in municipalities that did not adopt the electronic voting is also important: as 10 shows, being near Lula amplifies the vote share at 0.007 p.p. to each 1 p.p. of this candidate. Considering the president election this impact hardly affects the results, but it is an important finding on how different voting mechanisms might affect elections. Tables 32 displays the same results for municipalities around the threshold of 40,500 electors, showing that this findings are robust even for small samples around the discontinuity. We also analyze the performance of the last candidates (position 8 to 12) as a robustness test. We find no impact of the vote share of the "book" candidates, multiplied by the paper ballot dummy, on these candidates. We also run a placebo using the 1994 data. We also run a placebo test, using the 1994 election and the municipalities that used electronic voting in 1998 as a placebo, finding only marginally significant impact that does not survive when analyzing the data around the threshold (tables 33 and 34).

Table 10: Paper Ballot impact on bookend candidates

\begin{tabular}{|c|c|c|c|c|c|c|}
\hline Dep. Var.: Bookend & \multicolumn{3}{|c|}{ Lula "bookends" } & \multicolumn{3}{|c|}{ FHC "bookends" } \\
\hline Regressions & 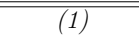 & 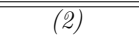 & 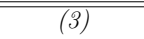 & (1) & (2) & 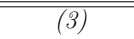 \\
\hline Paper Ballot & $\begin{array}{c}0.00757^{* * *} \\
(0.0005)\end{array}$ & $\begin{array}{c}0.00727^{* * *} \\
(0.0008)\end{array}$ & $\begin{array}{c}0.00740 * * * \\
(0.0007)\end{array}$ & $\begin{array}{c}0.00598^{* * *} \\
(0.0009)\end{array}$ & $\begin{array}{c}0.00364^{* * *} \\
(0.0008)\end{array}$ & $\begin{array}{c}0.00385^{* * *} \\
(0.0007)\end{array}$ \\
\hline "Book" Vote Share & & $\begin{array}{c}0.00388^{* *} \\
(0.0017)\end{array}$ & $\begin{array}{c}0.00374^{* *} \\
(0.0016)\end{array}$ & & $\begin{array}{c}1.633^{* * *} \\
(0.4300)\end{array}$ & $\begin{array}{c}1.610^{* * * *} \\
(0.4220)\end{array}$ \\
\hline "Book" Vote Share $*($ PaperBallot==1) & & $\begin{array}{c}0.00651^{* * *} \\
(0.0021)\end{array}$ & $\begin{array}{c}0.00698^{* * *} \\
(0.0020)\end{array}$ & & $\begin{array}{l}-0.307 \\
(0.4590)\end{array}$ & $\begin{array}{l}-0.296 \\
(0.4450)\end{array}$ \\
\hline Paper Ballot*Years of schooling & & & $\begin{array}{c}-0.00110^{* * *} \\
(0.0003)\end{array}$ & & & $\begin{array}{c}-0.000724^{* *} \\
(0.0003)\end{array}$ \\
\hline Constant & $\begin{array}{c}0.00645^{* * *} \\
(0.0014)\end{array}$ & $\begin{array}{c}0.00461^{* *} \\
(0.0016)\end{array}$ & $\begin{array}{c}0.00474^{* * *} \\
(0.0015)\end{array}$ & $\begin{array}{c}0.00614^{* * *} \\
(0.0014)\end{array}$ & $\begin{array}{c}-0.00123 \\
(0.0014) \\
\end{array}$ & $\begin{array}{c}-0.00114 \\
(0.0014) \\
\end{array}$ \\
\hline Observations & 5182 & 5182 & 5182 & 5182 & 5182 & 5182 \\
\hline
\end{tabular}

Using average years of schooling, percentage of poor people, longevity HDI, inequality (Theil Index), children mortality, house infrastructure (telephone and electricity), percentage of woman, mayor party, mayor vote share on the last election, number of electors (as deviation from the threshold), state/municipality fixed effects, electors age composition (young and elderly), political engagement as controls

Alternatively to conventional studies of residual votes and the association of high frequency of vote errors with specific voting technologies (as in Dee, 2007), we believe that major candidates works as a gravitational force for the elector that is "reading" the paper ballot to identify his candidate. The low impact on bookend candidates corroborate this interpretation since it is not expected a big share of electors who leave their choice to the moment of voting.

We also affirmed before that by imposing step-by-step procedure and a different voting order, the electronic voting affected elections results through a different channel than the impact derived from a change of voting mechanism. In that sense, table 11 shows the 
impact of the DRE on invalid votes for the "first" vote casted by the elector. For the year of 1994 and the municipalities with paper ballot in 1998, the first vote is for the president office: as figure 3 shows, it is the first information displayed for the elector on the paper ballot. For the municipalities with electronic voting it is the federal deputy one.

Table 11: Electronic voting impact on the "first" vote

\begin{tabular}{|c|c|c|}
\hline Dep. Var.: Vote Order & & \\
\hline Regressions & (1) & (2) \\
\hline Electronic Voting (EV) & $\begin{array}{c}0.00195 \\
(0.0055)\end{array}$ & \\
\hline Year $=1998$ & $\begin{array}{c}0.00262^{* * *} \\
(0.0007)\end{array}$ & $\begin{array}{c}0.00475^{* * *} \\
(0.0007)\end{array}$ \\
\hline EV * Year $=1998[\mathrm{EV}(98)]$ & $\begin{array}{c}-0.144^{* * *} \\
(0.0079)\end{array}$ & $\begin{array}{c}-0.144^{* * *} \\
(0.0079)\end{array}$ \\
\hline Poor People (\%) & $\begin{array}{c}0.00917^{* * *} \\
(0.0017)\end{array}$ & \\
\hline EV $(98) *$ Poor People (\%) & $\begin{array}{c}-0.0255^{* * *} \\
(0.0053)\end{array}$ & $\begin{array}{c}-0.0274^{* * *} \\
(0.0055)\end{array}$ \\
\hline EV*Poor People (\%) & $\begin{array}{c}0.0134^{* * *} \\
(0.0047)\end{array}$ & \\
\hline Year $=1998^{*}$ Poor People $(\%)$ & $\begin{array}{c}-0.00251^{*} \\
(0.0013)\end{array}$ & $\begin{array}{c}-0.00285^{* *} \\
(0.0013)\end{array}$ \\
\hline Years of study & $\begin{array}{c}-0.0347^{* * *} \\
(0.0018)\end{array}$ & \\
\hline EV $(98)^{*}$ Years of study & $\begin{array}{c}0.0310^{* * *} \\
(0.0049)\end{array}$ & $\begin{array}{c}0.0303^{* * *} \\
(0.0051)\end{array}$ \\
\hline EV*Years of study & $\begin{array}{c}0.00786^{*} \\
(0.0043)\end{array}$ & \\
\hline Year $=1998^{*}$ Years of study & $\begin{array}{c}-0.00182 \\
(0.0015)\end{array}$ & $\begin{array}{c}-0.00103 \\
(0.0015)\end{array}$ \\
\hline Constant & $\begin{array}{c}0.235^{* * *} \\
(0.0077)\end{array}$ & $\begin{array}{c}0.209 * * * \\
(0.0077)\end{array}$ \\
\hline Observations & 9375 & 9375 \\
\hline
\end{tabular}

(1) Pooled regression; (2) Fixed Effects

Using average years of schooling, percentage of poor people, longevity HDI, inequality (Theil Index),children mortality, house infrastructure (telephone and electricity), percentage of woman, mayor party, mayor vote share on the last election, number of electors (as deviation from the threshold), state/municipality fixed effects,electors age composition (young and elderly), political engagement as controls

Considering just the difference between invalid votes between this two offices (table 1) this analysis should indicate a positive impact: by exchanging the number of invalid of the president office for the federal deputy one should increase the number of invalid votes for the first choice. However, not only we identify a negative and significant impact, but the magnitude is around $12 \%$. More than mitigating obstacles imposed by paper voting, the DRE brought a method of voting that also lead to a drastic reduction on vote alienation. 


\subsection{Political Competition and resource allocation}

Until now we developed a plot-line of how the introduction of a new voting mechanism affected politics in Brazil. First, we showed that, by making the vote process easier it translated into a enfranchising phenomenon associated mostly with legislative elections. Moreover, by providing a visual confirmation for the elector and changing the order of how this elector votes, it resulted in an increase of party code votes and of vote dispersion on municipalities. It also affected specific parties, affecting negatively major parties as the loss of some are uncompensated by the gains of others. Summing up, it brought "new" electors to the election process and made major elections more competitive, what brings us to our final question: ultimately, this process affected municipal-level politics?

At a first glance, our response would be that we have a weak impact. As Table 35 shows the impact on the difference of the share of each municipal expenditure category between 1998 and 1999. It displays a small impact on municipal resource allocation, specifically the share of health spending, but the result is not confirmed if we attain ourselves to the cities around the threshold. But if we divide that municipalities between low level of prior competition (cities at the bottom of legislative office 1994 party code fractionalization) and the ones with high competition, we see a different result. As it is displayed on table 12, when competition is low, the introduction of the electronic voting, representing an increase in competition, led to a higher share of health oriented spending. Table 36 displays that the same pattern is not observed for the municipalities with high competition. ${ }^{33}$ Tables 38-39 displays the same results, using the data from the National Treasury (which has a smaller number of observations) and comparing the years of 1999 and 1997, providing more robustness to our findings. ${ }^{34}$

It is important to emphasize here that we are not concluding that health spending is the ultimate response for an unexpected increase in political competition (in the sense that spending in this specific item lessen the effects of the change in politics scenario in a broad sense). Nonetheless, we identify a concomitant shift in resource allocation which could be interpreted as how political forces reacted to this historical fact. At that time, health administration was passing by a process of decentralization (increasing municipalities participation in public health care budget), but still a big share of health expenditure in Brazil was Federal and the State government responsability (in 1998 this two government spheres spent $75 \%$ of all public budget oriented to health care - Kilsztajn et al., 2003).

\footnotetext{
${ }^{33}$ This results are in line with the findings of Reingewertz (2009).

${ }^{34}$ As explained before, we are unable to compare the same years of the IBGE data because of data availability
} 
Table 12: Electronic voting impact on municpality resource allocation (99 vs 98 - IBGE)

\begin{tabular}{|c|c|c|c|c|c|c|c|c|c|c|}
\hline \multirow{3}{*}{$\frac{\text { Regressions }}{\text { Transportation (\%) }}$} & \multirow{3}{*}{$\begin{array}{l}\text { Full Sample } \\
\\
-0.00697 \\
(0.0061)\end{array}$} & \multicolumn{9}{|c|}{ Bottom Fractionalization } \\
\hline & & \multicolumn{3}{|c|}{ Full Sample } & \multicolumn{3}{|c|}{ Threshold $\pm 20 \mathrm{k}$} & \multicolumn{3}{|c|}{ Threshold $\pm 15 \mathrm{k}$} \\
\hline & & $\begin{array}{c}-0.0144 \\
(0.0092)\end{array}$ & $\begin{array}{c}-0.0132 \\
(0.0086)\end{array}$ & $\begin{array}{c}-0.0148^{*} \\
(0.0085)\end{array}$ & $\begin{array}{c}-0.0302 \\
(0.0206)\end{array}$ & $\begin{array}{c}-0.0298 \\
(0.0218)\end{array}$ & $\begin{array}{c}-0.0302 \\
(0.0235)\end{array}$ & $\begin{array}{c}-0.0267 \\
(0.0252)\end{array}$ & $\begin{array}{c}-0.0265 \\
(0.0260)\end{array}$ & $\begin{array}{c}-0.0262 \\
(0.0264)\end{array}$ \\
\hline Health (\%) & $\begin{array}{c}0.0187^{* *} \\
(0.0077)\end{array}$ & $\begin{array}{c}0.0350^{* * *} \\
(0.0074)\end{array}$ & $\begin{array}{c}0.0374^{* * *} \\
(0.0091)\end{array}$ & $\begin{array}{c}0.0324^{* * *} \\
(0.0089)\end{array}$ & $\begin{array}{c}0.0804^{* * * *} \\
(0.0228)\end{array}$ & $\begin{array}{c}0.0821 * * * \\
(0.0225)\end{array}$ & $\begin{array}{c}0.0865^{* * *} \\
(0.0288)\end{array}$ & $\begin{array}{c}0.0757^{* *} \\
(0.0307)\end{array}$ & $\begin{array}{c}0.0736^{* *} \\
(0.0313)\end{array}$ & $\begin{array}{c}0.0783^{* *} \\
(0.0362)\end{array}$ \\
\hline Social Security (\%) & $\begin{array}{c}-0.00313 \\
(0.0046)\end{array}$ & $\begin{array}{c}-0.00352 \\
(0.0065)\end{array}$ & $\begin{array}{c}-0.00659 \\
(0.0071)\end{array}$ & $\begin{array}{c}-0.00714 \\
(0.0079)\end{array}$ & $\begin{array}{c}-0.0391 \text { *** } \\
(0.0132)\end{array}$ & $\begin{array}{c}-0.0406^{* *} \\
(0.0149)\end{array}$ & $\begin{array}{c}-0.0348^{* *} \\
(0.0161)\end{array}$ & $\begin{array}{c}-0.0391^{* *} \\
(0.0149)\end{array}$ & $\begin{array}{c}-0.0378^{*} \\
(0.0189)\end{array}$ & $\begin{array}{c}-0.0237 \\
(0.0169)\end{array}$ \\
\hline Legislative Functions (\%) & $\begin{array}{c}0.00605 \\
(0.0073)\end{array}$ & $\begin{array}{l}0.0104 \\
(0.0104)\end{array}$ & $\begin{array}{c}0.00757 \\
(0.0105)\end{array}$ & $\begin{array}{c}0.00816 \\
(0.0106)\end{array}$ & $\begin{array}{c}0.0109 \\
(0.0144)\end{array}$ & $\begin{array}{c}0.00874 \\
(0.0144)\end{array}$ & $\begin{array}{c}0.00763 \\
(0.0155)\end{array}$ & $\begin{array}{c}0.00983 \\
(0.0179)\end{array}$ & $\begin{array}{c}0.00996 \\
(0.0200)\end{array}$ & $\begin{array}{l}0.0103 \\
(0.0186)\end{array}$ \\
\hline Housing (\%) & $\begin{array}{c}-0.00745 \\
(0.0089)\end{array}$ & $\begin{array}{c}-0.0152 \\
(0.0131)\end{array}$ & $\begin{array}{c}-0.0157 \\
(0.0126)\end{array}$ & $\begin{array}{l}-0.0143 \\
(0.0124)\end{array}$ & $\begin{array}{l}-0.04 \\
(0.0344)\end{array}$ & $\begin{array}{c}-0.0323 \\
(0.0327)\end{array}$ & $\begin{array}{c}-0.0437 \\
(0.0393)\end{array}$ & $\begin{array}{c}-0.0379 \\
(0.0321)\end{array}$ & $\begin{array}{c}-0.0374 \\
(0.0359)\end{array}$ & $\begin{array}{c}-0.0568 \\
(0.0450)\end{array}$ \\
\hline Education (\%) & $\begin{array}{c}-0.011 \\
(0.0123)\end{array}$ & $\begin{array}{c}-0.00715 \\
(0.0156)\end{array}$ & $\begin{array}{c}-0.00788 \\
(0.0175)\end{array}$ & $\begin{array}{c}-0.00737 \\
(0.0173)\end{array}$ & $\begin{array}{c}-0.0281 \\
(0.0215)\end{array}$ & $\begin{array}{c}-0.0247 \\
(0.0237)\end{array}$ & $\begin{array}{c}-0.0263 \\
(0.0258)\end{array}$ & $\begin{array}{c}-0.038 \\
(0.0300)\end{array}$ & $\begin{array}{c}-0.0394 \\
(0.0334)\end{array}$ & $\begin{array}{c}-0.0478 \\
(0.0413)\end{array}$ \\
\hline Agriculture (\%) & $\begin{array}{c}0.00127 \\
(0.0027)\end{array}$ & $\begin{array}{c}-0.000327 \\
(0.0039)\end{array}$ & $\begin{array}{c}0.000342 \\
(0.0052)\end{array}$ & $\begin{array}{c}0.000562 \\
(0.0052)\end{array}$ & $\begin{array}{c}0.00441 \\
(0.0060)\end{array}$ & $\begin{array}{c}0.00555 \\
(0.0066)\end{array}$ & $\begin{array}{c}0.00584 \\
(0.0066)\end{array}$ & $\begin{array}{c}0.00193 \\
(0.0036)\end{array}$ & $\begin{array}{c}0.00411 \\
(0.0041)\end{array}$ & $\begin{array}{c}0.000242 \\
(0.0039)\end{array}$ \\
\hline Administration (\%) & $\begin{array}{c}0.0101 \\
(0.0124)\end{array}$ & $\begin{array}{c}0.00466 \\
(0.0128)\end{array}$ & $\begin{array}{c}0.00337 \\
(0.0133)\end{array}$ & $\begin{array}{c}0.00612 \\
(0.0141)\end{array}$ & $\begin{array}{c}0.0304 \\
(0.0198)\end{array}$ & $\begin{array}{c}0.0188 \\
(0.0195)\end{array}$ & $\begin{array}{c}0.0143 \\
(0.0198)\end{array}$ & $\begin{array}{l}0.019 \\
(0.0261)\end{array}$ & $\begin{array}{c}0.0128 \\
(0.0257)\end{array}$ & $\begin{array}{c}0.0102 \\
(0.0297)\end{array}$ \\
\hline Total Spent & $\begin{array}{c}0.0156 \\
(0.0654) \\
\end{array}$ & $\begin{array}{r}-0.046 \\
(0.0823) \\
\end{array}$ & $\begin{array}{c}-0.0398 \\
(0.0908) \\
\end{array}$ & $\begin{array}{c}-0.0465 \\
(0.0953) \\
\end{array}$ & $\begin{array}{c}-0.0586 \\
(0.1170) \\
\end{array}$ & $\begin{array}{c}-0.0422 \\
(0.1170) \\
\end{array}$ & $\begin{array}{c}-0.0263 \\
(0.1050) \\
\end{array}$ & $\begin{array}{c}-0.0253 \\
(0.1270) \\
\end{array}$ & $\begin{array}{c}-0.00188 \\
(0.1370) \\
\end{array}$ & $\begin{array}{c}0.0143 \\
(0.1230) \\
\end{array}$ \\
\hline $\begin{array}{l}\text { Observations } \\
\text { Controls }\end{array}$ & 4881 & 2194 & 2194 & 2194 & 249 & 249 & 249 & 161 & 161 & 161 \\
\hline State & Yes & No & Yes & Yes & No & Yes & Yes & No & Yes & No \\
\hline Mayor Party & Yes & No & No & Yes & No & No & Yes & No & No & Yes \\
\hline
\end{tabular}

Using average years of schooling, percentage of poor people, longevity HDI, inequality (Theil Index), children mortality, house infrastructure (telephone and electricity), percentage of woman, mayor party, mayor vote share on the last election, number of electors (as deviation from the threshold), state/municipality fixed effects,electors age composition (young and elderly), political engagement as controls

Table 37 shows that we do not identify a change on revenues distributions for the same group with the IBGE data nor, as table 40 shows, with the National Treasury data. We also find no effect of Federal deputies amendments distribution between 2000 and 1998 and between 1999 and 1998.

Also, it's important to emphasize that the year of 2000 is marked by the first year of mayor' election with the possibility of reelection (approved by an Constitutional Amendment in 1997) and by the universal adoption of the electronic voting by Brazilian municipalities. Considering this, we understand we interpret the change on expenditure allocation as an attempt to undermine the "new" political paradigm established by the electronic voting. 


\section{Conclusion}

The baseline aspect over which this dissertation was built was an enfranchising effect brought by the introduction of electronic voting in Brazilian elections. We showed that the increase in valid votes was a consequence of a reduction on both blank and spoiled votes, associated with less educated group (specially for spoiled votes), being the effect heterogeneous according to municipalities characteristics and the office analyzed. From that result, we demonstrated that the decrease in vote alienation affected electoral competition and political behavior. First, it is shown that, specially for the legislators office, this resulted in: a) increase in parties strength; b) affected negatively major parties; c) increased the level of competition measured by vote fractionalization. Finally, we found evidence that it affected mayors' decision about resource allocation, specifically an association between the electronic voting and an increase in health resource budget share in municipalities with previous low level of political competition. This finding suggest that resource re-allocation was a result of the impact of electronic voting in political competition, interpreted under a wider connection between municipal-level politics and legislative election.

The relation between recording political preferences and voting technology is extremely important for the well-functioning democracy. We believe this dissertation contribute to the discussion of voting technology, specially in Brazil, and to recent discussions about the order of candidates in the electronic machine and biometric voting system, which should be considered under the effects of both electoral results and political outcomes. 


\section{Bibliography}

ALVAREZ, M. et al. Voting: What is, what could be. Pasadena, CA: Caltech/MIT Voting Technology Project, 2001.

ALVES, M. State and opposition in military Brazil. [S.l.]: University of Texas Press Austin, TX., 1985.

ANSOLABEHERE, S.; STEWART III, C. Residual votes attributable to technology. Journal of Politics, Wiley Online Library, v. 67, n. 2, p. 365-389, 2005.

BESLEY, T.; PERSSON, T.; STURM, D. Political competition, policy and growth: theory and evidence from the us. Review of Economic Studies, Wiley Online Library, v. 77, n. 4, p. 1329-1352, 2010.

BOSSERT, W.; D'AMBROSIO, C.; FERRARA, E. L. A generalized index of fractionalization. Economica, Wiley Online Library, 2011.

CABRAL, M. C.; FALCÃO, M. No congresso, 1/5 quer trocar cadeira atual por prefeitura. Folha de São Paulo, São Paulo, jan. 2012. Disponível em: <http://www1.folha.uol.com.br/poder/1031725-no-congresso-15-quer-trocar-cadeiraatual-por-prefeitura.shtml>. Acesso em: 01 nov. 2012.

CARD, D.; MORETTI, E. Does voting technology affect election outcomes? touch-screen voting and the 2004 presidential election. The Review of Economics and Statistics, MIT Press, v. 89, n. 4, p. 660-673, 2007.

DEE, T. Technology and voter intent: Evidence from the california recall election. The Review of Economics and Statistics, MIT Press, v. 89, n. 4, p. 674-683, 2007.

FUJIWARA, T. A regression discontinuity test of strategic voting and duverger's law. 2008.

FUJIWARA, T. Voting technology, political responsiveness, and infant health: evidence from brazil. Department of Economics, University of British Columbia. http://grad. econ. ubc. ca/fujiwara/jmp. pdf, 2010.

GALLUCCI, M. Tse alerta sobre mudança na ordem de votação na urna. Estado de São Paulo, São Paulo, jun. 2010. Disponível em: $<$ http://www.estadao.com.br/noticias/nacional,tse-alerta-sobre-mudanca-na-ordemde-votacao-na-urna,571559,0.htm>. Acesso em: 01 nov. 2012.

GONÇALVES, C.; MADEIRA, R.; RODRIGUES, M. Two-ballot vs. plurality rule: An empirical investigation on the number of candidates. 2008.

HERRNSON, P. et al. Early appraisals of electronic voting. Social Science Computer Review, Sage Publications, v. 23, n. 3, p. 274-292, 2005.

HIRCZY, W. The impact of mandatory voting laws on turnout: A quasi-experimental approach. Electoral Studies, Elsevier, v. 13, n. 1, p. 64-76, 1994.

KATZ, G. A statistical model of abstention under compulsory voting. IMT Institute for Advanced Studies, Lucca, 2011. 
KILSZTAJN, S. et al. Serviços de saúde, gastos e envelhecimento da população brasileira. Rev Bras Estud Popul, v. 20, n. 1, p. 93-108, 2003.

LEE, D.; MORETTI, E.; BUTLER, M. Do voters affect or elect policies? evidence from the us house. The Quarterly Journal of Economics, Oxford University Press, v. 119, n. 3, p. 807, 2004.

MELLO, J. D.; FIRPO, S.; CHAMON, M. Electoral rules, political competition and fiscal spending: Regression discontinuity evidence from brazilian municipalities. 2009.

NICOLAU, J. A participação eleitoral: evidências sobre o caso brasileiro. In: Congresso Luso-Afro-Brasileiro de Ciências Sociais. [S.l.: s.n.], 2004. v. 7.

POWER, T.; GARAND, J. Determinants of invalid voting in latin america. Electoral Studies, Elsevier, v. 26, n. 2, p. 432-444, 2007.

POWER, T.; ROBERTS, J. Compulsory voting, invalid ballots, and abstention in brazil. Political Research Quarterly, Sage Publications, v. 48, n. 4, p. 795-826, 1995.

REINGEWERTZ, Y. Political competition, ethnic fragmentation and fiscal status: Evidence from municipalities in israel. 2009.

SAMUELS, D. Ambition, federalism, and legislative politics in Brazil. [S.1.]: Cambridge University Press, 2003.

TOLEDO, J. R. d. Crônica de um erro ignorado. O Estado de São Paulo, São Paulo, 8 nov. 2010. Disponível em: <http://blogs.estadao.com.br/vox-publica/2010/11/07/cronica-deum-erro-ignorado/>. Acesso em: 1 nov. 2012. 


\section{List of Appendices}

Descriptive Statistics . . . . . . . . . . . . . . . 62

Legislative seats distribution formula . . . . . . . . . . . 65

C

Additional Results . . . . . . . . . . . . . . . . 66

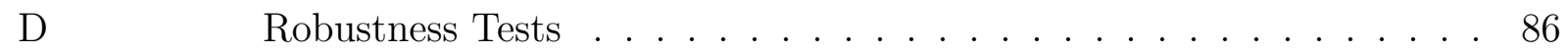

D.1 Results with municipalities with number of electors around the thre-

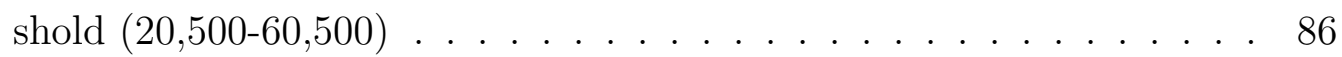

D.2 Results with municipalities with tight 1996 mayor election margin of

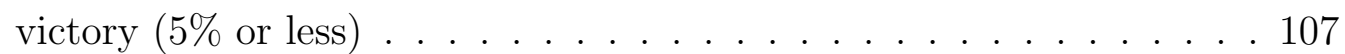

D.3 Results using 2002 election data . . . . . . . . . . . 125 


\section{A Descriptive Statistics}

Table 13: Socioeconomic Characteristics

\begin{tabular}{lrrr}
\hline Variables & Mean & Median & Std. \\
\hline \hline & & & \\
Illiterates (\% - 1991) & 31.12 & 26.33 & 16.90 \\
Average years of schooling (1991) & 3.04 & 3.08 & 1.27 \\
Rural population (\%) & 50.37 & 51.08 & 25.94 \\
Wealth HDI (1991) & 0.55 & 0.55 & 0.10 \\
Inequality (Theil Index) & 0.49 & 0.48 & 0.12 \\
Poor population (\%) & 58.46 & 61.57 & 23.06
\end{tabular}

Source: Brazilian Institute of Geography and Statistics (IBGE) and Institute for Applied Economic Research (IPEA) and

Table 14: Share (\%) of each item on municipality budget (1999)

\begin{tabular}{lrrr}
\hline Variables & Mean & Median & Std. \\
\hline \hline & & & \\
Legislative Functions & 4.80 & 4.59 & 2.14 \\
Administration & 19.86 & 18.44 & 7.74 \\
Agriculture & 2.40 & 1.48 & 2.89 \\
Education & 34.01 & 33.82 & 7.25 \\
Housing & 9.34 & 8.55 & 6.16 \\
Health & 15.99 & 15.19 & 6.60 \\
Social Security & 6.20 & 5.46 & 4.03 \\
Transportation & 7.30 & 5.95 & 6.22 \\
\hline Source Brazilion Institute of Geography and Statistics (IBGE)
\end{tabular}

\begin{tabular}{|c|c|c|c|c|}
\hline \multirow[b]{3}{*}{ Political Office } & \multicolumn{4}{|c|}{ Number of candidates, per office } \\
\hline & \multicolumn{2}{|c|}{1994 Election } & \multicolumn{2}{|c|}{1998 Election } \\
\hline & Min & Max & Min & $\operatorname{Max}$ \\
\hline President & - & 8 & - & 12 \\
\hline State Governor & 3 & 8 & 4 & 13 \\
\hline Senator & 5 & 13 & 3 & 14 \\
\hline Federal Deputy & 32 & 525 & 38 & 657 \\
\hline State Deputy & 115 & 1006 & 128 & 1302 \\
\hline
\end{tabular}

Source: Superior Electoral Court (TSE) 
Table 15: 1994/1998 Election data

\begin{tabular}{|c|c|c|c|c|c|c|}
\hline \multirow[t]{2}{*}{ Variables } & \multicolumn{3}{|c|}{1994} & \multicolumn{3}{|c|}{1998} \\
\hline & Mean & Median & Std. & Mean & Median & Std. \\
\hline Number of electors & 18886 & 7180 & 118951 & 19276 & 6876 & 126114 \\
\hline \multicolumn{7}{|l|}{ President } \\
\hline Invalid vote (\%) & 23.24 & 22.19 & 7.16 & 23.35 & 22.49 & 6.78 \\
\hline Spoiled vote (\%) & 10.15 & 9.76 & 3.63 & 9.9 & 9.47 & 3.71 \\
\hline Blank vote $(\%)$ & 13.09 & 12.38 & 4.84 & 13.46 & 13.03 & 5.46 \\
\hline Fractionalization (party code) & 0.53 & 0.53 & 0.13 & 0.53 & 0.55 & 0.1 \\
\hline PSDB (party code \%) & 60.23 & 63.98 & 17.12 & 59.66 & 61.84 & 14.55 \\
\hline PT (party code $\%)$ & 21.45 & 19.45 & 10.25 & 24.79 & 21.93 & 12.89 \\
\hline PMDB (party code \%) & 6.47 & 4.51 & 5.53 & 0 & 0 & 0 \\
\hline PFL (party code \%) & 0 & 0 & 0 & 0 & 0 & 0 \\
\hline Mayor party vote & 8.34 & 1.01 & 16.84 & 11.11 & 0 & 23.89 \\
\hline \multicolumn{7}{|l|}{ Governor } \\
\hline Invalid vote (\%) & 30.43 & 29.49 & 9.35 & 27.79 & 26.06 & 9.77 \\
\hline Spoiled vote (\%) & 6.91 & 6.55 & 2.71 & 6.71 & 5.75 & 4.36 \\
\hline Blank vote $(\%)$ & 23.53 & 22.21 & 8.2 & 21.09 & 19.79 & 9.74 \\
\hline Fractionalization (party code) & 0.57 & 0.58 & 0.1 & 0.53 & 0.54 & 0.13 \\
\hline PSDB (party code \%) & 14.7 & 0 & 20.68 & 19.28 & 4.4 & 23.44 \\
\hline PT (party code $\%)$ & 7.01 & 4.01 & 9.05 & 8.8 & 4.5 & 11.8 \\
\hline PMDB (party code \%) & 23.09 & 16.08 & 22.27 & 31.74 & 34.83 & 25.67 \\
\hline PFL (party code \%) & 10.55 & 0 & 20.31 & 20.3 & 0 & 29.22 \\
\hline Mayor party vote & 17.34 & 0.95 & 23.23 & 22.08 & 0.39 & 26.98 \\
\hline \multicolumn{7}{|l|}{ Federal Deputy } \\
\hline Invalid vote $(\%)$ & 41.53 & 41.56 & 9.34 & 28.78 & 29 & 9.86 \\
\hline Spoiled vote (\%) & 21.76 & 21.04 & 6.74 & 14.76 & 14.56 & 6.04 \\
\hline Blank vote $(\%)$ & 19.77 & 19.13 & 5.66 & 14.03 & 13.76 & 5.08 \\
\hline Fractionalization (party code) & 0.67 & 0.71 & 0.14 & 0.72 & 0.75 & 0.1 \\
\hline PSDB (party code \%) & 14.35 & 11.25 & 13.72 & 28.87 & 26.54 & 18.17 \\
\hline PT (party code $\%)$ & 38.23 & 37.16 & 20.84 & 15.27 & 12.44 & 11.45 \\
\hline PMDB (party code \%) & 15.94 & 12.5 & 13.5 & 19.16 & 15.91 & 14.82 \\
\hline PFL (party code \%) & 7.2 & 2.39 & 11.49 & 12.95 & 5.91 & 15.43 \\
\hline Mayor party vote & 22.92 & 16.45 & 22.97 & 23.4 & 16.32 & 23.16 \\
\hline \multicolumn{7}{|l|}{ State Deputy } \\
\hline Invalid vote (\%) & 34.71 & 34.16 & 9.94 & 23.93 & 23.08 & 8.97 \\
\hline Spoiled vote $(\%)$ & 17.41 & 16.5 & 6.15 & 13.28 & 12.73 & 5.7 \\
\hline Blank vote $(\%)$ & 17.29 & 16.47 & 5.94 & 10.65 & 10.04 & 4.23 \\
\hline Fractionalization (party code) & 0.65 & 0.7 & 0.16 & 0.74 & 0.77 & 0.1 \\
\hline PSDB (party code \%) & 10.31 & 6.25 & 12.47 & 25.18 & 23.23 & 17.03 \\
\hline PT (party code \%) & 38.33 & 37.66 & 22.63 & 14.46 & 11.84 & 11.09 \\
\hline PMDB (party code \%) & 16.32 & 12.27 & 15.26 & 19.75 & 16.97 & 14.92 \\
\hline PFL (party code \%) & 8.04 & 2.3 & 13.27 & 13.35 & 7.14 & 15.44 \\
\hline Mayor party vote & 22.98 & 16.79 & 22.82 & 21.42 & 14.32 & 21.73 \\
\hline
\end{tabular}

Source: Superior Electoral Court (TSE) 


\section{B Legislative seats distribution formula}

Considering the office $o$, in the State $s$, with $V_{o, s}$ valid votes, $P$ parties with $v_{p, o, s}$ votes for each $p \in P$ and $K_{o, s}$ seats, we have the following scheme for the seats distribution:

i.The Electoral quota $\left(Q^{E}\right)$ is defined by $Q_{o, s}^{E}=\frac{V_{o, s}}{K_{o, s}}$;

ii.Each party $p$ receives the integer part of $Q_{p, o, s}=\frac{v_{p, o, s}}{Q_{o, s}^{E}}$, the party quota;

iii.In case there are leftovers, the remainder seats are distributed according to the rule:

1)The party with the greatest $Q_{p, o, s}=\frac{v_{p, o s}}{Q_{p, o, s}+1}$ receives an extra seat, updating $Q_{p, o, s}=$ $Q_{p, o, s}+1$

2)Repeat step iii.1 until all seats are allocated. 


\section{Additional Results}

Table 16: Electronic voting impact on Turnout

\begin{tabular}{|c|c|c|}
\hline \multicolumn{3}{|l|}{ Dep. Var.: Turnout } \\
\hline Regressions & (1) & $\overline{(2)}$ \\
\hline Electronic Voting (EV) & $\begin{array}{c}0.0262^{* * *} \\
(0.0070)\end{array}$ & \\
\hline Year $=1998$ & $\begin{array}{c}-0.0183^{* * *} \\
(0.0009)\end{array}$ & $\begin{array}{c}-0.0179^{* * *} \\
(0.0008)\end{array}$ \\
\hline EV * Year $=1998[\mathrm{EV}(98)]$ & $\begin{array}{c}-0.0287^{* * *} \\
(0.0060)\end{array}$ & $\begin{array}{c}-0.0266^{* * *} \\
(0.0066)\end{array}$ \\
\hline Poor People (\%) & $\begin{array}{c}-0.0248^{* * *} \\
(0.0026)\end{array}$ & \\
\hline EV $(98) *$ Poor People $(\%)$ & $\begin{array}{c}0.0283^{* * *} \\
(0.0043)\end{array}$ & $\begin{array}{c}0.0206^{* * *} \\
(0.0051)\end{array}$ \\
\hline EV*Poor People (\%) & $\begin{array}{c}-0.0110^{*} \\
(0.0061)\end{array}$ & \\
\hline Year $=1998^{*}$ Poor People $(\%)$ & $\begin{array}{c}-0.00322^{*} \\
(0.0017)\end{array}$ & $\begin{array}{c}-0.000509 \\
(0.0014)\end{array}$ \\
\hline Years of study & $\begin{array}{c}0.0312^{* * *} \\
(0.0026)\end{array}$ & \\
\hline EV $(98) *$ Years of study & $\begin{array}{c}0.0213^{* * *} \\
(0.0042)\end{array}$ & $\begin{array}{c}0.0189^{* * *} \\
(0.0054)\end{array}$ \\
\hline $\mathrm{EV}^{*}$ Years of study & $\begin{array}{c}0.00182 \\
(0.0063)\end{array}$ & \\
\hline Year $=1998^{*}$ Years of study & $\begin{array}{c}-0.00682^{* * *} \\
(0.0018)\end{array}$ & $\begin{array}{c}-0.00449^{\text {*** }} \\
(0.0014)\end{array}$ \\
\hline Constant & $\begin{array}{c}0.772^{* * *} \\
(0.0116) \\
\end{array}$ & $\begin{array}{c}0.723^{* * *} \\
(0.0107) \\
\end{array}$ \\
\hline Observations & 9375 & 9375 \\
\hline
\end{tabular}

Using average years of schooling, percentage of poor people, longevity HDI, inequality (Theil Index), children mortality, house infrastructure (telephone and electricity), percentage of woman, mayor party,mayor vote share on the last election, number of electors (as deviation from the threshold), state/municipality fixed effects,electors age composition (young and elderly), political engagement as controls 
Table 17: Electronic voting impact on Candidate Fractionalization

\begin{tabular}{|c|c|c|c|c|}
\hline \multirow{2}{*}{$\begin{array}{l}\text { Dep. Var.: Fractionalization (cand.) } \\
\text { Regressions }\end{array}$} & \multicolumn{2}{|c|}{ Federal Deputy } & \multicolumn{2}{|c|}{ State Deputy } \\
\hline & (1) & (2) & (1) & (2) \\
\hline Electronic Voting (EV) & $\begin{array}{c}-0.361^{* *} \\
(0.1640)\end{array}$ & & $\begin{array}{c}-0.457^{* * *} \\
(0.1700)\end{array}$ & \\
\hline Year $=1998$ & $\begin{array}{c}-0.0712^{* * *} \\
(0.0207)\end{array}$ & $\begin{array}{c}-0.0221 \\
(0.0210)\end{array}$ & $\begin{array}{c}-0.0747^{* * *} \\
(0.0240)\end{array}$ & $\begin{array}{c}-0.0512^{* *} \\
(0.0249)\end{array}$ \\
\hline EV * Year $=1998[\mathrm{EV}(98)]$ & $\begin{array}{c}0.544^{* *} \\
(0.2240)\end{array}$ & $\begin{array}{c}0.568^{* * *} \\
(0.2150)\end{array}$ & $\begin{array}{c}0.290^{*} \\
(0.1720)\end{array}$ & $\begin{array}{l}0.273 \\
(0.1840)\end{array}$ \\
\hline Poor People (\%) & $\begin{array}{c}0.163^{* * *} \\
(0.0404)\end{array}$ & & $\begin{array}{c}0.204^{* * *} \\
(0.0405)\end{array}$ & \\
\hline EV $(98) *$ Poor People (\%) & $\begin{array}{c}0.372^{* *} \\
(0.1730)\end{array}$ & $\begin{array}{c}0.433^{* *} \\
(0.1690)\end{array}$ & $\begin{array}{c}-0.262^{*} \\
(0.1540)\end{array}$ & $\begin{array}{r}-0.181 \\
(0.1440)\end{array}$ \\
\hline EV*Poor People (\%) & $\begin{array}{c}0.0594 \\
(0.1450)\end{array}$ & & $\begin{array}{c}0.648^{* * *} \\
(0.1650)\end{array}$ & \\
\hline Year $=1998^{*}$ Poor People $(\%)$ & $\begin{array}{c}0.0631^{*} \\
(0.0383)\end{array}$ & $\begin{array}{c}0.0642^{*} \\
(0.0377)\end{array}$ & $\begin{array}{l}0.017 \\
(0.0391)\end{array}$ & $\begin{array}{c}0.0202 \\
(0.0394)\end{array}$ \\
\hline Years of study & $\begin{array}{c}0.383^{* * *} \\
(0.0405)\end{array}$ & & $\begin{array}{c}0.191^{* * *} \\
(0.0431)\end{array}$ & \\
\hline EV $(98) *$ Years of study & $\begin{array}{c}0.276^{*} \\
(0.1600)\end{array}$ & $\begin{array}{c}0.264^{*} \\
(0.1480)\end{array}$ & $\begin{array}{c}-0.0935 \\
(0.1230)\end{array}$ & $\begin{array}{c}-0.0666 \\
(0.1210)\end{array}$ \\
\hline EV*Years of study & $\begin{array}{c}-0.285^{* *} \\
(0.1370)\end{array}$ & & $\begin{array}{c}0.355^{* *} \\
(0.1410)\end{array}$ & \\
\hline Year $=1998^{*}$ Years of study & $\begin{array}{l}0.017 \\
(0.0377)\end{array}$ & $\begin{array}{c}0.0326 \\
(0.0368)\end{array}$ & $\begin{array}{c}0.0602 \\
(0.0393)\end{array}$ & $\begin{array}{c}0.0760^{*} \\
(0.0396)\end{array}$ \\
\hline \# of candidates & $\begin{array}{c}0.00155^{* * *} \\
(0.0004)\end{array}$ & $\begin{array}{c}0.00154^{* * *} \\
(0.0004)\end{array}$ & $\begin{array}{c}0.000392^{* * *} \\
(0.0001)\end{array}$ & $\begin{array}{c}0.000411^{* * *} \\
(0.0001)\end{array}$ \\
\hline Constant & $\begin{array}{c}1.179^{* * *} \\
(0.1510) \\
\end{array}$ & $\begin{array}{c}-0.337^{*} \\
(0.1870) \\
\end{array}$ & $\begin{array}{c}1.137^{* * * *} \\
(0.1740) \\
\end{array}$ & $\begin{array}{c}-0.0546 \\
(0.1720) \\
\end{array}$ \\
\hline $\begin{array}{l}\text { Robust s } \\
* * * \mathrm{p}\end{array}$ & $\begin{array}{c}9375 \\
\text { rd errors } \\
* * \mathrm{p}<0 .\end{array}$ & $\begin{array}{c}9375 \\
\text { oarentheses } \\
* \mathrm{p}<0.1\end{array}$ & 9375 & 9375 \\
\hline
\end{tabular}

(1) Pooled regression; (2) Fixed Effects

Using average years of schooling, percentage of poor people, longevity HDI, inequality (Theil Index), children mortality, house infrastructure (telephone and electricity), percentage of woman, mayor party,mayor vote share on the last election, number of electors (as deviation from the threshold), state/municipality fixed effects, electors age composition (young and elderly), political engagement as controls

Table 18: Electronic voting impact on Best Loser Votes

\begin{tabular}{|c|c|c|c|c|}
\hline Dep. Var.: Best Loser & \multicolumn{2}{|c|}{ Vote Share } & \multicolumn{2}{|c|}{ Run for Mayor } \\
\hline Regressions & (1) & (2) & (1) & (2) \\
\hline Electronic Voting (EV) & $\begin{array}{c}0.108 \text { *** } \\
(0.0354)\end{array}$ & & $\begin{array}{c}0.000864 \\
(0.0008)\end{array}$ & \\
\hline Year $=1998$ & $\begin{array}{c}-0.0222^{* * *} \\
(0.0039)\end{array}$ & $\begin{array}{c}-0.0186^{* * *} \\
(0.0042)\end{array}$ & $\begin{array}{c}0.000413 \\
(0.0005)\end{array}$ & $\begin{array}{c}-0.000325 \\
(0.0003)\end{array}$ \\
\hline EV * Year $=1998[E V(98)]$ & $\begin{array}{c}-0.000706 \\
(0.0376)\end{array}$ & $\begin{array}{c}-0.00141 \\
(0.0369)\end{array}$ & $\begin{array}{c}-0.0000317 \\
(0.0005)\end{array}$ & $\begin{array}{c}0.000293 \\
(0.0005)\end{array}$ \\
\hline$(=1)$ if Federal & $\begin{array}{c}-0.0205^{* * *} \\
(0.0038)\end{array}$ & $\begin{array}{c}-0.0136^{* * *} \\
(0.0051)\end{array}$ & $\begin{array}{c}0.000214 \\
(0.0005)\end{array}$ & $\begin{array}{c}0.00064 \\
(0.0006)\end{array}$ \\
\hline (=1) Mayor Party & $\begin{array}{c}0.0764^{* * *} \\
(0.0067)\end{array}$ & $\begin{array}{c}0.0542^{* * *} \\
(0.0081)\end{array}$ & $\begin{array}{c}0.00139 \\
(0.0012)\end{array}$ & $\begin{array}{c}0.00131 \\
(0.0014)\end{array}$ \\
\hline Mayor Popularity & $\begin{array}{c}-0.00706^{* *} \\
(0.0033)\end{array}$ & $\begin{array}{c}0.000551 \\
(0.0040)\end{array}$ & $\begin{array}{c}0.00027 \\
(0.0003)\end{array}$ & $\begin{array}{c}-0.000449 \\
(0.0005)\end{array}$ \\
\hline EV $(98)^{*}$ Poor People (\%) & $\begin{array}{c}0.0294 \\
(0.0309)\end{array}$ & $\begin{array}{c}0.0159 \\
(0.0298)\end{array}$ & $\begin{array}{c}-0.000644 \\
(0.0006)\end{array}$ & $\begin{array}{c}-0.000245 \\
(0.0004)\end{array}$ \\
\hline EV(98)*Years of study & $\begin{array}{c}0.0123 \\
(0.0262)\end{array}$ & $\begin{array}{c}0.0117 \\
(0.0231)\end{array}$ & $\begin{array}{c}-0.00182 \\
(0.0016)\end{array}$ & $\begin{array}{c}-0.00032 \\
(0.0005)\end{array}$ \\
\hline Constant & $\begin{array}{c}0.347^{* * *} \\
(0.0300)\end{array}$ & $\begin{array}{c}0.169 * * * \\
(0.0318) \\
\end{array}$ & $\begin{array}{c}-0.000928 \\
(0.0008) \\
\end{array}$ & $\begin{array}{c}0.000171 \\
(0.0009)\end{array}$ \\
\hline Observations & 8948 & 8948 & 8948 & 8948 \\
\hline
\end{tabular}

Using average years of schooling, percentage of poor people, longevity HDI, inequality (Theil Index), children mortality, house infrastructure (telephone and electricity), percentage of woman, mayor party, mayor vote share on the last election, number of electors (as deviation from the threshold), state/municipality fixed effects,electors age composition (young and elderly), political engagement as controls 
Table 19: Electronic voting impact on Best Loser Votes (State Deputy Only)

\begin{tabular}{|c|c|c|c|c|}
\hline \multirow{2}{*}{$\begin{array}{l}\text { Dep. Var.: Best Loser } \\
\text { Regressions }\end{array}$} & \multicolumn{2}{|c|}{ Vote Share } & \multicolumn{2}{|c|}{ Run for Mayor } \\
\hline & (1) & (2) & (1) & $\overline{(2)}$ \\
\hline \multirow[t]{2}{*}{ Electronic Voting (EV) } & 0.0379 & & 0.000821 & \\
\hline & $(0.0281)$ & & $(0.0008)$ & \\
\hline \multirow[t]{2}{*}{ Year $=1998$} & $-0.0242^{* * *}$ & $-0.0229 * * *$ & 0.000614 & -0.0000728 \\
\hline & $(0.0042)$ & $(0.0047)$ & $(0.0005)$ & $(0.0001)$ \\
\hline \multirow[t]{2}{*}{$\mathrm{EV} *$ Year $=1998[\mathrm{EV}(98)]$} & 0.0414 & $0.0623^{* *}$ & -0.00019 & -0.00000582 \\
\hline & $(0.0325)$ & $(0.0302)$ & $(0.0003)$ & $(0.0002)$ \\
\hline \multirow[t]{2}{*}{$(=1)$ Mayor Party } & $0.0854^{* * *}$ & $0.0625^{* * *}$ & 0.00061 & -0.000149 \\
\hline & $(0.0076)$ & $(0.0100)$ & $(0.0010)$ & $(0.0002)$ \\
\hline \multirow[t]{2}{*}{ Mayor Popularity } & -0.0047 & 0.0035 & 0.000343 & 0.00012 \\
\hline & $(0.0034)$ & $(0.0043)$ & $(0.0003)$ & $(0.0001)$ \\
\hline \multirow[t]{2}{*}{ EV $(98) *$ Poor People $(\%)$} & 0.0377 & 0.0302 & -0.000996 & -0.000446 \\
\hline & $(0.0269)$ & $(0.0253)$ & $(0.0008)$ & $(0.0005)$ \\
\hline \multirow[t]{2}{*}{ Constant } & $0.266^{* * *}$ & $0.121^{* * *}$ & -0.000461 & -0.000109 \\
\hline & $(0.0296)$ & $(0.0289)$ & $(0.0006)$ & $(0.0004)$ \\
\hline \multirow[t]{2}{*}{ Constant } & $0.266^{* * *}$ & $0.121^{* * *}$ & -0.000461 & -0.000109 \\
\hline & $(0.0296)$ & $(0.0289)$ & $(0.0006)$ & $(0.0004)$ \\
\hline Observations & 7974 & 7974 & 7974 & 7974 \\
\hline
\end{tabular}

(1) Pooled regression; (2) Fixed Effects

Using average years of schooling, percentage of poor people, longevity HDI, inequality (Theil Index), children mortality, house infrastructure (telephone and electricity), percentage of woman, mayor party, mayor vote share on the last election, number of electors (as deviation from the threshold), state/municipality fixed effects, electors age composition (young and elderly), political engagement as controls

Table 20: Electronic voting impact on PT party code votes (over total party code votes)

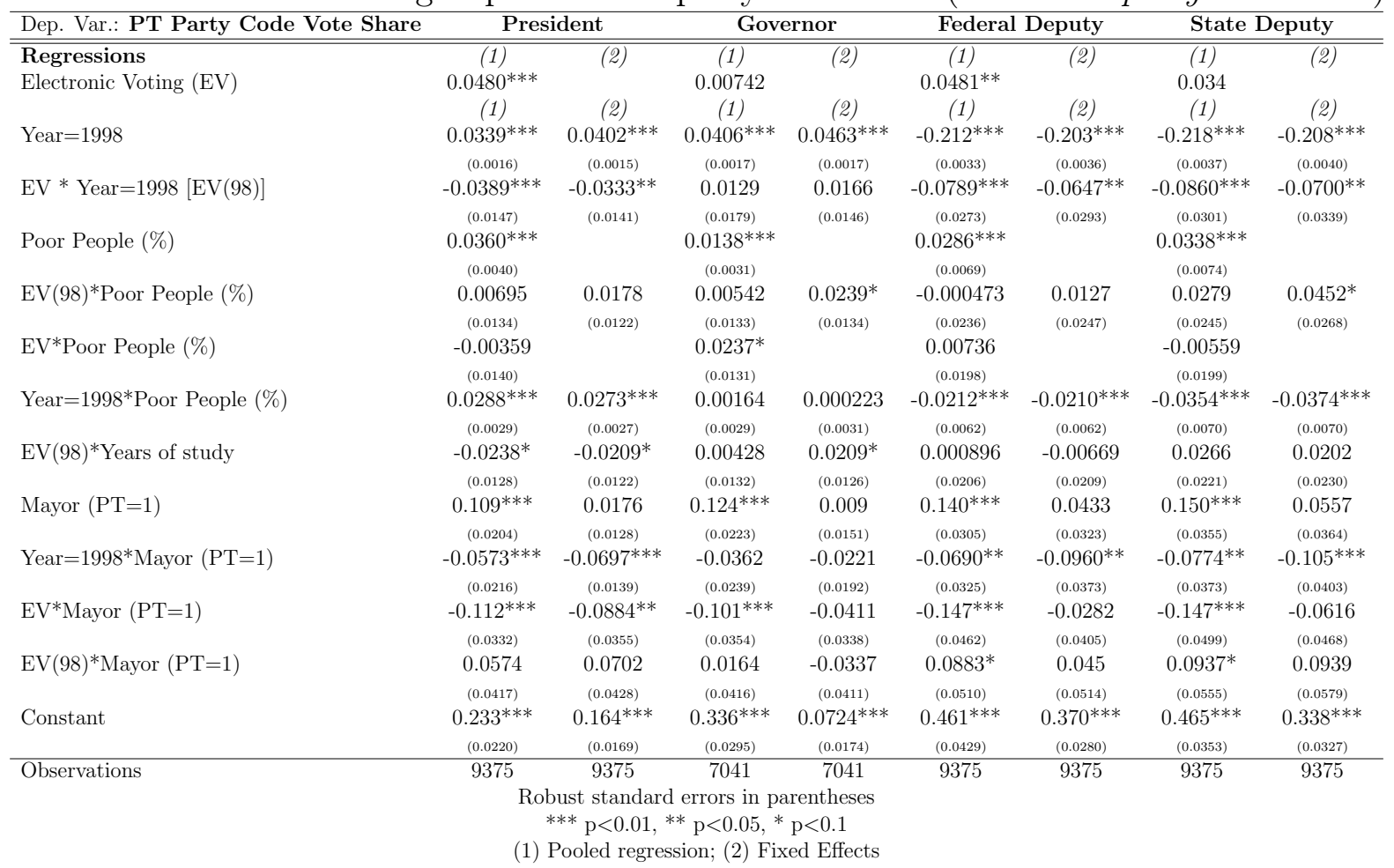

Using average years of schooling, percentage of poor people, longevity HDI, inequality (Theil Index), children mortality, house infrastructure (telephone and electricity), percentage of woman, mayor party, mayor vote share on the last election, number of electors (as deviation from the threshold), state/municipality fixed effects, electors age composition (young and elderly), political engagement as controls 
Table 21: Electronic voting impact on PSDB Votes party code votes (over total party code votes)

\begin{tabular}{|c|c|c|c|c|c|c|c|c|}
\hline Dep. Var.: PSDB Party Code Vote Share & Pres & dent & Gove & rnor & Federal & Deputy & State D & eputy \\
\hline Regressions & (1) & (2) & (1) & (2) & (1) & (2) & (1) & (2) \\
\hline Electronic Voting (EV) & $\begin{array}{c}-0.0133 \\
(0.0182)\end{array}$ & & $\begin{array}{c}0.0345 \\
(0.0230)\end{array}$ & & $\begin{array}{c}-0.00916 \\
(0.0154)\end{array}$ & & $\begin{array}{c}-0.00245 \\
(0.0152)\end{array}$ & \\
\hline Year $=1998$ & $\begin{array}{c}0.0114^{\text {*** }} \\
(0.0025)\end{array}$ & $\begin{array}{c}0.0159^{* * *} \\
(0.0026)\end{array}$ & $\begin{array}{c}0.0655^{* * *} \\
(0.0063)\end{array}$ & $\begin{array}{c}0.0737^{* * *} \\
(0.0079)\end{array}$ & $\begin{array}{c}0.141^{* * * *} \\
(0.0028)\end{array}$ & $\begin{array}{c}0.137^{* * *} \\
(0.0031)\end{array}$ & $\begin{array}{c}0.134^{* * *} \\
(0.0027)\end{array}$ & $\begin{array}{c}0.132^{* * *} \\
(0.0031)\end{array}$ \\
\hline $\mathrm{EV} * \mathrm{Year}=1998[\mathrm{EV}(98)]$ & $\begin{array}{c}0.0136 \\
(0.0226)\end{array}$ & $\begin{array}{c}0.0158 \\
(0.0222)\end{array}$ & $\begin{array}{c}-0.00819 \\
(0.0334)\end{array}$ & $\begin{array}{c}-0.0492 \\
(0.0472)\end{array}$ & $\begin{array}{c}-0.0587^{* * * *} \\
(0.0184)\end{array}$ & $\begin{array}{c}-0.0484^{* * * *} \\
(0.0187)\end{array}$ & $\begin{array}{l}0.024 \\
(0.0185)\end{array}$ & $\begin{array}{c}0.0307 \\
(0.0199)\end{array}$ \\
\hline Poor People (\%) & $\begin{array}{c}-0.0465 * * * \\
(0.0049)\end{array}$ & & $\begin{array}{c}-0.0885 * * * \\
(0.0076)\end{array}$ & & $\begin{array}{c}-0.0114^{* * *} \\
(0.0044)\end{array}$ & & $\begin{array}{c}-0.00918^{* *} \\
(0.0042)\end{array}$ & \\
\hline EV $(98) *$ Poor People (\%) & $\begin{array}{c}-0.0318^{*} \\
(0.0167)\end{array}$ & $\begin{array}{c}-0.0387^{* *} \\
(0.0152)\end{array}$ & $\begin{array}{c}0.0341 \\
(0.0300)\end{array}$ & $\begin{array}{c}0.000953 \\
(0.0364)\end{array}$ & $\begin{array}{c}-0.0000854 \\
(0.0139)\end{array}$ & $\begin{array}{l}0.0107 \\
(0.0139)\end{array}$ & $\begin{array}{c}0.0491^{* * *} \\
(0.0151)\end{array}$ & $\begin{array}{c}0.0568^{* * *} \\
(0.0146)\end{array}$ \\
\hline EV*Poor People (\%) & $\begin{array}{c}0.00949 \\
(0.0158)\end{array}$ & & $\begin{array}{c}0.00889 \\
(0.0237)\end{array}$ & & $\begin{array}{c}-0.00339 \\
(0.0138)\end{array}$ & & $\begin{array}{c}-0.00365 \\
(0.0138)\end{array}$ & \\
\hline Year $=1998^{*}$ Poor People $(\%)$ & $\begin{array}{c}-0.0292^{* * *} \\
(0.0044)\end{array}$ & $\begin{array}{c}-0.0302 * * * \\
(0.0043)\end{array}$ & $\begin{array}{c}0.173^{* * *} \\
(0.0096)\end{array}$ & $\begin{array}{c}0.197^{* * *} \\
(0.0116)\end{array}$ & $\begin{array}{c}-0.0116^{* *} \\
(0.0054)\end{array}$ & $\begin{array}{c}-0.0115^{* *} \\
(0.0054)\end{array}$ & $\begin{array}{c}-0.0036 \\
(0.0053)\end{array}$ & $\begin{array}{c}-0.00176 \\
(0.0053)\end{array}$ \\
\hline $\mathrm{EV}(98)^{*}$ Years of study & $\begin{array}{c}-0.00875 \\
(0.0150)\end{array}$ & $\begin{array}{c}-0.0088 \\
(0.0135)\end{array}$ & $\begin{array}{l}-0.027 \\
(0.0288)\end{array}$ & $\begin{array}{c}-0.0544 \\
(0.0344)\end{array}$ & $\begin{array}{c}0.0259^{* *} \\
(0.0130)\end{array}$ & $\begin{array}{c}0.0222^{*} \\
(0.0127)\end{array}$ & $\begin{array}{c}0.0207 \\
(0.0126)\end{array}$ & $\begin{array}{c}0.0187 \\
(0.0125)\end{array}$ \\
\hline Mayor $(\mathrm{PSDB}=1)$ & $\begin{array}{c}0.0611^{* * *} \\
(0.0082)\end{array}$ & $\begin{array}{c}0.0806^{* * *} \\
(0.0095)\end{array}$ & $\begin{array}{c}0.0612^{* * *} \\
(0.0125)\end{array}$ & $\begin{array}{c}0.0341^{*} \\
(0.0202)\end{array}$ & $\begin{array}{c}0.0537^{* * *} \\
(0.0094)\end{array}$ & $\begin{array}{l}0.0157 \\
(0.0131)\end{array}$ & $\begin{array}{c}0.0528^{* * *} \\
(0.0107)\end{array}$ & $\begin{array}{c}0.0230^{*} \\
(0.0136)\end{array}$ \\
\hline Year $=1998^{*}$ Mayor $(\mathrm{PSDB}=1)$ & $\begin{array}{c}-0.0815^{* * *} \\
(0.0087)\end{array}$ & $\begin{array}{c}-0.126^{* * *} \\
(0.0097)\end{array}$ & $\begin{array}{c}-0.0509 \text { *** } \\
(0.0130)\end{array}$ & $\begin{array}{c}-0.0711^{* * *} * \\
(0.0212)\end{array}$ & $\begin{array}{c}0.00861 \\
(0.0102)\end{array}$ & $\begin{array}{c}0.0483^{* * *} \\
(0.0134)\end{array}$ & $\begin{array}{c}0.00656 \\
(0.0112)\end{array}$ & $\begin{array}{c}0.0401 * * * \\
(0.0139)\end{array}$ \\
\hline EV*Mayor $(\mathrm{PSDB}=1)$ & $\begin{array}{c}-0.0296^{*} \\
(0.0178)\end{array}$ & $\begin{array}{c}-0.0334^{*} \\
(0.0200)\end{array}$ & $\begin{array}{c}0.0212 \\
(0.0219)\end{array}$ & $\begin{array}{l}0.051 \\
(0.0345)\end{array}$ & $\begin{array}{c}-0.0385^{* *} \\
(0.0186)\end{array}$ & $\begin{array}{c}0.0119 \\
(0.0210)\end{array}$ & $\begin{array}{c}-0.0525 * * * \\
(0.0184)\end{array}$ & $\begin{array}{c}-0.00832 \\
(0.0213)\end{array}$ \\
\hline $\mathrm{EV}(98) *$ Mayor $(\mathrm{PSDB}=1)$ & $\begin{array}{c}0.00112 \\
(0.0220)\end{array}$ & $\begin{array}{c}0.0241 \\
(0.0219)\end{array}$ & $\begin{array}{c}-0.0386 \\
(0.0303)\end{array}$ & $\begin{array}{c}-0.0281 \\
(0.0407)\end{array}$ & $\begin{array}{c}-0.0572^{* *} \\
(0.0227)\end{array}$ & $\begin{array}{c}-0.0867^{* * *} \\
(0.0231)\end{array}$ & $\begin{array}{c}-0.0232 \\
(0.0229)\end{array}$ & $\begin{array}{c}-0.0468^{* *} \\
(0.0237)\end{array}$ \\
\hline Constant & $\begin{array}{c}0.532 * * * \\
(0.0211)\end{array}$ & $\begin{array}{c}0.587 * * * \\
(0.0204)\end{array}$ & $\begin{array}{c}0.470 * * * \\
(0.0185)\end{array}$ & $\begin{array}{c}0.269 * * * \\
(0.0386)\end{array}$ & $\begin{array}{c}-0.0146 \\
(0.0126)\end{array}$ & $\begin{array}{c}0.0844^{* * *} \\
(0.0201)\end{array}$ & $\begin{array}{c}-0.0367^{* * *} \\
(0.0116)\end{array}$ & $\begin{array}{c}0.0351^{*} \\
(0.0201)\end{array}$ \\
\hline Observations & 9375 & 9375 & 4759 & 4759 & 9375 & 9375 & 9375 & 9375 \\
\hline
\end{tabular}

(1) Pooled regression; (2) Fixed Effects

Using average years of schooling, percentage of poor people, longevity HDI, inequality (Theil Index), children mortality, house infrastructure (telephone and electricity), percentage of woman, mayor party, mayor vote share on the last election, number of electors (as deviation from the threshold), state/municipality fixed effects,electors age composition (young and elderly), political engagement as controls 
Table 22: Electronic voting impact on PMDB Votes party code votes (over total party code votes)

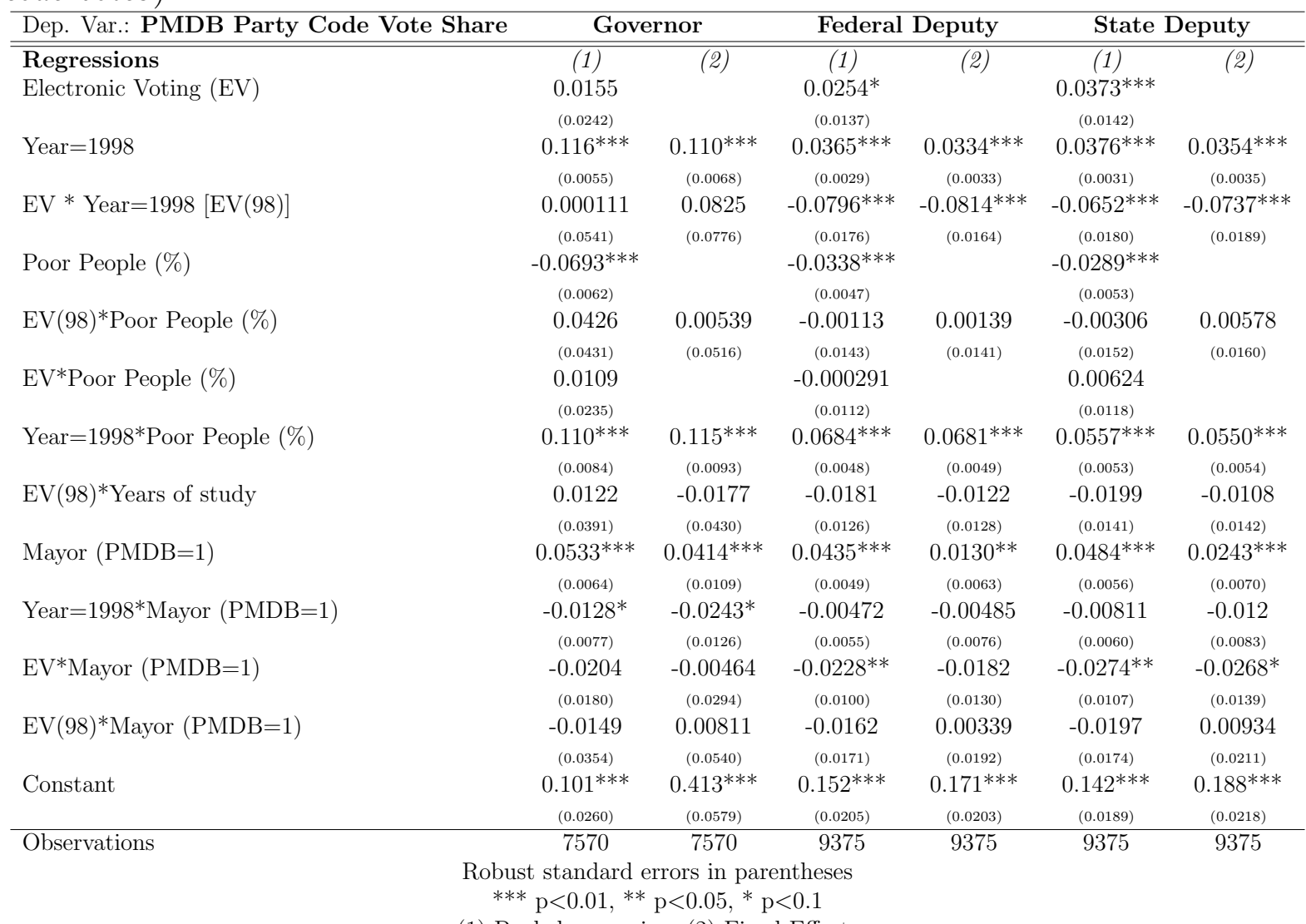

(1) Pooled regression; (2) Fixed Effects

Using average years of schooling, percentage of poor people, longevity HDI, inequality (Theil Index), children mortality, house infrastructure (telephone and electricity), percentage of woman, mayor party, mayor vote share on the last election, number of electors (as deviation from the threshold), state/municipality fixed effects,electors age composition (young and elderly), political engagement as controls 
Table 23: Electronic voting impact on PFL Votes party code votes (over total party code votes)

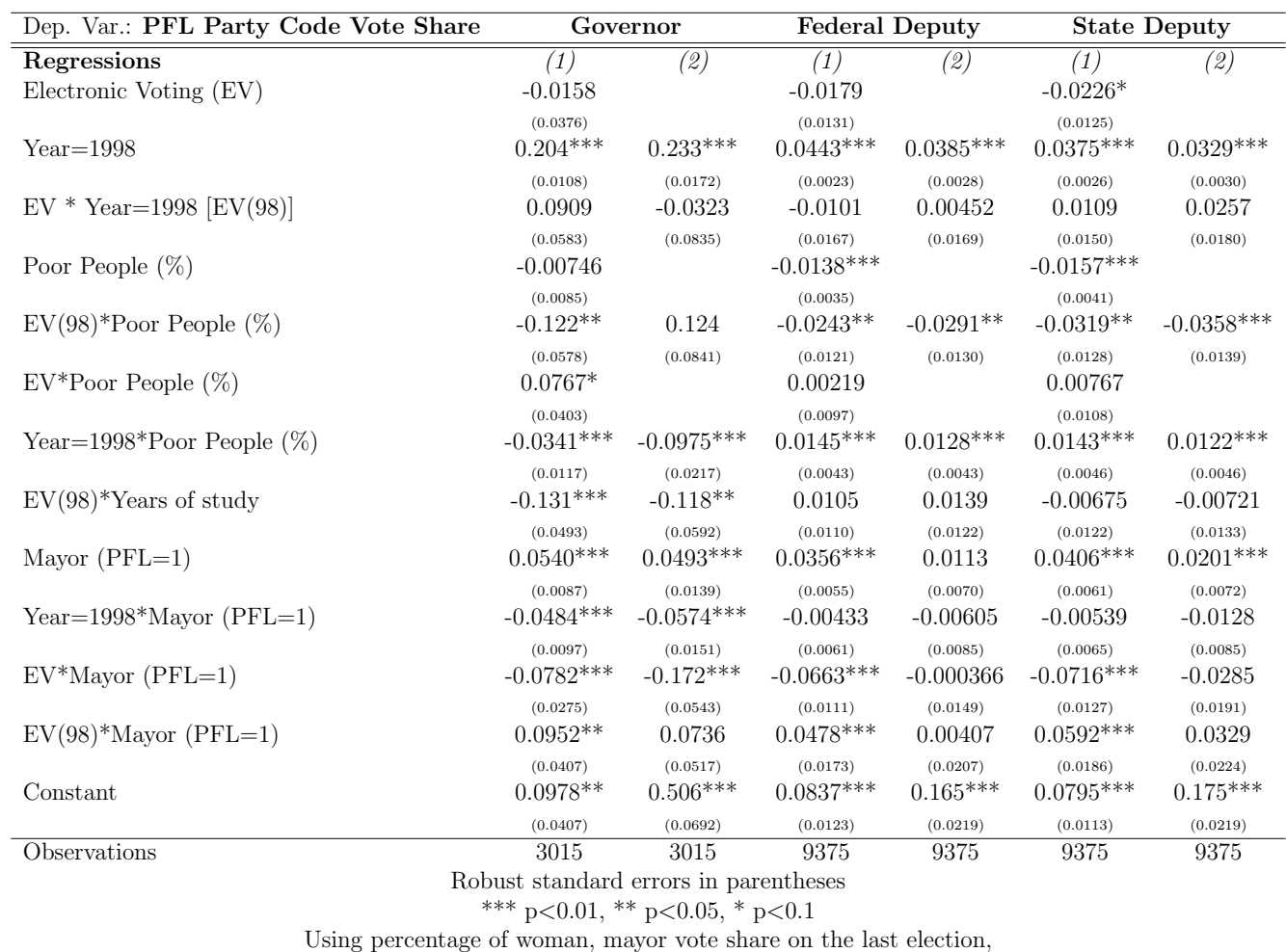

Using average years of schooling, percentage of poor people, longevity HDI, inequality (Theil Index),children mortality, house infrastructure (telephone and electricity), percentage of woman, mayor party, mayor vote share on the last election, number of electors (as deviation from the threshold), state/municipality fixed effects, electors age composition (young and elderly), political engagement as controls 
Table 24: Electronic voting impact on Votes for the Mayor Party

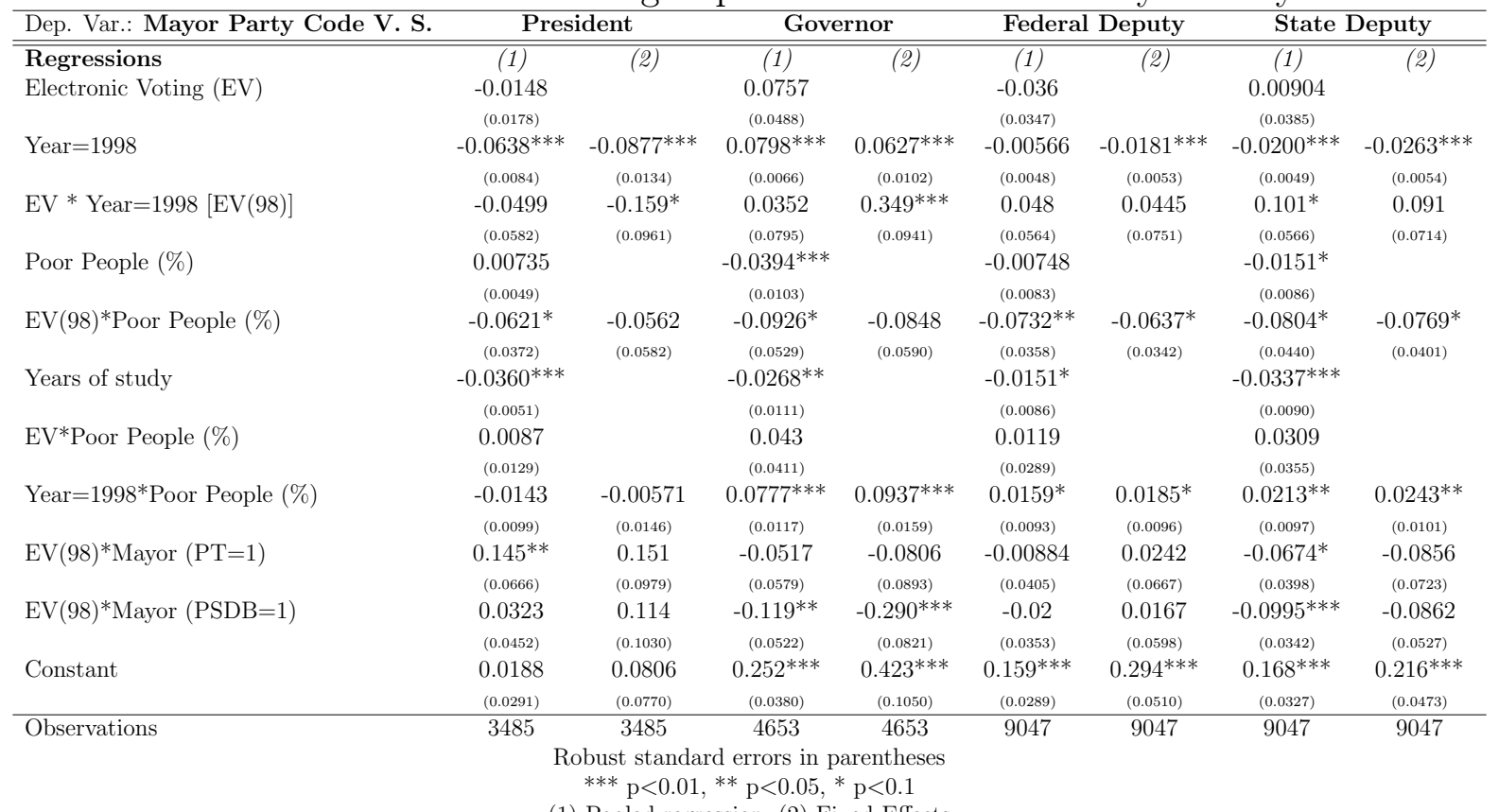

(1) Pooled regression; (2) Fixed Effects

Using average years of schooling, percentage of poor people, longevity HDI, inequality (Theil Index), children mortality, house infrastructure (telephone and electricity), percentage of woman, mayor party, mayor vote share on the last election, number of electors (as deviation from the threshold), state/municipality fixed effects,electors age composition (young and elderly), political engagement as controls 
Table 25: Electronic voting impact on Party Code Votes from the Mayor Party (over total party code votes)

\begin{tabular}{|c|c|c|c|c|}
\hline Dep. Var.: Mayor Party Code V. S. & \multicolumn{2}{|c|}{ Federal Deputy } & \multicolumn{2}{|c|}{ State Deputy } \\
\hline Regressions & (1) & (2) & (1) & $(2)$ \\
\hline Electronic Voting (EV) & $\begin{array}{c}-0.0347^{* *} \\
(0.0155)\end{array}$ & & $\begin{array}{c}-0.0353^{*} \\
(0.0191)\end{array}$ & \\
\hline Year $=1998$ & $\begin{array}{c}0.0180^{* * *} \\
(0.0033)\end{array}$ & $\begin{array}{c}0.00686^{*} \\
(0.0038)\end{array}$ & $\begin{array}{c}0.0103^{* * *} \\
(0.0036)\end{array}$ & $\begin{array}{c}-0.0000719 \\
(0.0041)\end{array}$ \\
\hline $\mathrm{EV} *$ Year $=1998[\mathrm{EV}(98)]$ & $\begin{array}{c}0.0338 \\
(0.0248)\end{array}$ & $\begin{array}{c}0.00751 \\
(0.0326)\end{array}$ & $\begin{array}{c}0.0559^{*} \\
(0.0308)\end{array}$ & $\begin{array}{c}0.0444 \\
(0.0362)\end{array}$ \\
\hline Poor People (\%) & $\begin{array}{c}-0.00406 \\
(0.0059)\end{array}$ & & $\begin{array}{c}-0.00169 \\
(0.0066)\end{array}$ & \\
\hline EV $(98) *$ Poor People (\%) & $\begin{array}{c}-0.0251 \\
(0.0194)\end{array}$ & $\begin{array}{r}-0.019 \\
(0.0205)\end{array}$ & $\begin{array}{c}-0.0191 \\
(0.0225)\end{array}$ & $\begin{array}{c}-0.0194 \\
(0.0223)\end{array}$ \\
\hline Years of study & $\begin{array}{c}-0.0378^{* * *} \\
(0.0064)\end{array}$ & & $\begin{array}{c}-0.0382^{* * *} \\
(0.0072)\end{array}$ & \\
\hline EV*Poor People (\%) & $\begin{array}{c}-0.00242 \\
(0.0144)\end{array}$ & & $\begin{array}{c}0.00088 \\
(0.0169)\end{array}$ & \\
\hline Year $=1998 *$ Poor People $(\%)$ & $\begin{array}{c}0.0136^{* *} \\
(0.0065)\end{array}$ & $\begin{array}{c}0.0185^{* * *} \\
(0.0068)\end{array}$ & $\begin{array}{c}0.00591 \\
(0.0069)\end{array}$ & $\begin{array}{c}0.0162^{* *} \\
(0.0072)\end{array}$ \\
\hline $\mathrm{EV}(98) *$ Mayor $(\mathrm{PT}=1)$ & $\begin{array}{c}-0.0633^{* *} \\
(0.0318)\end{array}$ & $\begin{array}{c}-0.0684 \\
(0.0451)\end{array}$ & $\begin{array}{c}-0.0836^{* *} \\
(0.0349)\end{array}$ & $\begin{array}{c}-0.101^{* *} \\
(0.0476)\end{array}$ \\
\hline $\mathrm{EV}(98)^{*}$ Mayor $(\mathrm{PMDB}=1)$ & $\begin{array}{c}-0.0722^{* * *} \\
(0.0176)\end{array}$ & $\begin{array}{c}-0.0326 \\
(0.0308)\end{array}$ & $\begin{array}{c}-0.0629^{* * *} \\
(0.0209)\end{array}$ & $\begin{array}{c}-0.0347 \\
(0.0303)\end{array}$ \\
\hline $\mathrm{EV}(98) *$ Mayor $(\mathrm{PSDB}=1)$ & $\begin{array}{c}-0.0590^{* * *} \\
(0.0184)\end{array}$ & $\begin{array}{c}-0.0336 \\
(0.0273)\end{array}$ & $\begin{array}{c}-0.00529 \\
(0.0214)\end{array}$ & $\begin{array}{c}0.00862 \\
(0.0286)\end{array}$ \\
\hline Constant & $\begin{array}{c}0.129 * * * \\
(0.0220)\end{array}$ & $\begin{array}{c}0.158^{* * *} \\
(0.0288)\end{array}$ & $\begin{array}{c}0.127^{* * *} \\
(0.0241)\end{array}$ & $\begin{array}{c}0.195^{* * *} \\
(0.0314)\end{array}$ \\
\hline Observations & 7930 & 7930 & 7753 & 7753 \\
\hline
\end{tabular}

Robust standard errors in parentheses

$$
\text { *** } \mathrm{p}<0.01, * * \mathrm{p}<0.05, * \mathrm{p}<0.1
$$

(1) Pooled regression; (2) Fixed Effects

Using average years of schooling, percentage of poor people, longevity HDI, inequality (Theil Index), children mortality, house infrastructure (telephone and electricity), percentage of woman, mayor party, mayor vote share on the last election, number of electors (as deviation from the threshold), state/municipality fixed effects,electors age composition (young and elderly), political 
Table 26: Electronic voting impact on the probability of choosing the same party for legislative and president offices

\begin{tabular}{lcccc}
\hline Dep. Var.: Prob. of voting on & \multicolumn{2}{c}{ PT } & \multicolumn{2}{c}{ PSDB } \\
\hline \hline Regressions & $(1)$ & $(2)$ & $(1)$ & $(2)$ \\
Electronic Voting (EV) & 0.000445 & & 0.00834 & \\
& $(0.0016)$ & & $(0.0060)$ & \\
Year=1998 & 0.00031 & $0.000588^{* * *}$ & $0.0117^{* * *}$ & $0.0122^{* * *}$ \\
& $(0.0003)$ & $(0.0002)$ & $(0.0013)$ & $(0.0014)$ \\
EV ${ }^{*}$ Year=1998 [EV(98)] & 0.00249 & 0.00282 & -0.00415 & -0.00174 \\
EV $(98)^{*}$ Poor People (\%) & $(0.0019)$ & $(0.0022)$ & $(0.0104)$ & $(0.0111)$ \\
& 0.000773 & $0.00428^{*}$ & $-0.0136^{*}$ & $-0.0116^{*}$ \\
EV $(98)^{*}$ Years of study & $(0.0027)$ & $(0.0025)$ & $(0.0070)$ & $(0.0064)$ \\
& -0.000279 & -0.000575 & $-0.00995^{* *}$ & $-0.00990^{* *}$ \\
Mayor & $(0.0022)$ & $(0.0020)$ & $(0.0049)$ & $(0.0049)$ \\
& $0.0289^{* * *}$ & -0.00295 & $0.0342^{* * *}$ & $0.0307^{* * *}$ \\
Year=1998*Mayor & $(0.0079)$ & $(0.0039)$ & $(0.0069)$ & $(0.0078)$ \\
& -0.00527 & 0.00302 & $-0.0180^{* *}$ & $-0.0179^{* *}$ \\
EV*Mayor & $(0.0073)$ & $(0.0050)$ & $(0.0071)$ & $(0.0086)$ \\
& -0.0171 & -0.00145 & $-0.0262^{* *}$ & -0.0111 \\
EV $(98)^{*}$ Mayor & $(0.0121)$ & $(0.0113)$ & $(0.0110)$ & $(0.0122)$ \\
Constant & 0.00328 & -0.00796 & 0.000507 & -0.0041 \\
& $(0.0137)$ & $(0.0140)$ & $(0.0129)$ & $(0.0131)$ \\
& 0.000907 & $0.00404^{* *}$ & 0.00571 & -0.00208 \\
Observations & $(0.0027)$ & $(0.0019)$ & $(0.0179)$ & $(0.0082)$ \\
\hline & 9375 & 9375 & 9375 & 9375 \\
& Robust standard errors in parentheses & &
\end{tabular}

(1) Pooled regression; (2) Fixed Effects

Using average years of schooling, percentage of poor people, longevity HDI, inequality (Theil Index), children mortality, house infrastructure (telephone and electricity), percentage of woman, mayor party, mayor vote share on the last election, number of electors (as deviation from the threshold), state/municipality fixed effects, electors age composition (young and elderly), political engagement as controls 
Table 27: Electronic voting impact on the probability of choosing the same party for legislative offices (party code votes)

\begin{tabular}{|c|c|c|c|c|c|c|}
\hline Dep. Var.: Prob. of voting on & \multicolumn{2}{|c|}{ PT } & \multicolumn{2}{|c|}{ PSDB } & \multicolumn{2}{|c|}{ PMDB } \\
\hline Regressions & (1) & $\overline{(2)}$ & (1) & (2) & (1) & $(2)$ \\
\hline Electronic Voting (EV) & $\begin{array}{c}0.0301 \\
(0.0236)\end{array}$ & & $\begin{array}{c}-0.0425^{* * *} \\
(0.0154)\end{array}$ & & $\begin{array}{r}-0.00353 \\
(0.0088)\end{array}$ & \\
\hline Year $=1998$ & $\begin{array}{c}-0.148^{* * *} \\
(0.0043)\end{array}$ & $\begin{array}{c}-0.143^{* * *} \\
(0.0050)\end{array}$ & $\begin{array}{c}-0.0274^{* * *} \\
(0.0065)\end{array}$ & $\begin{array}{c}-0.0372^{* * *} \\
(0.0077)\end{array}$ & $\begin{array}{c}-0.0165^{* * *} \\
(0.0048)\end{array}$ & $\begin{array}{c}-0.0239 * * * \\
(0.0056)\end{array}$ \\
\hline $\mathrm{EV} *$ Year $=1998[\mathrm{EV}(98)]$ & $\begin{array}{l}-0.0393 \\
(0.0270)\end{array}$ & $\begin{array}{l}-0.0333 \\
(0.0301)\end{array}$ & $\begin{array}{c}0.0842^{* * *} \\
(0.0160)\end{array}$ & $\begin{array}{c}0.0738 * * * \\
(0.0154)\end{array}$ & $\begin{array}{l}0.00946 \\
(0.0098)\end{array}$ & $\begin{array}{l}0.00845 \\
(0.0089)\end{array}$ \\
\hline EV $(98) *$ Poor People (\%) & $\begin{array}{l}0.00888 \\
(0.0236)\end{array}$ & $\begin{array}{c}0.0233 \\
(0.0249)\end{array}$ & $\begin{array}{c}0.0908 * * * \\
(0.0154)\end{array}$ & $\begin{array}{c}0.0722^{* * *} \\
(0.0151)\end{array}$ & $\begin{array}{l}0.00658 \\
(0.0096)\end{array}$ & $\begin{array}{l}0.00291 \\
(0.0099)\end{array}$ \\
\hline $\mathrm{EV}(98)^{*}$ Years of study & $\begin{array}{l}0.00289 \\
(0.0203)\end{array}$ & $\begin{array}{r}-0.00211 \\
(0.0211)\end{array}$ & $\begin{array}{l}0.0248^{*} \\
(0.0144)\end{array}$ & $\begin{array}{c}0.0183 \\
(0.0145)\end{array}$ & $\begin{array}{c}-0.0276^{* * *} \\
(0.0101)\end{array}$ & $\begin{array}{c}-0.0269^{* *} \\
(0.0108)\end{array}$ \\
\hline Mayor & $\begin{array}{c}0.0345^{* * * *} \\
(0.0120)\end{array}$ & $\begin{array}{c}-0.0447^{* * *} \\
(0.0173)\end{array}$ & $\begin{array}{c}0.0392^{* * *} \\
(0.0084)\end{array}$ & $\begin{array}{c}0.0756^{* * *} \\
(0.0128)\end{array}$ & $\begin{array}{c}0.0114 \\
(0.0075)\end{array}$ & $\begin{array}{c}0.0000982 \\
(0.0090)\end{array}$ \\
\hline Year $=1998^{*}$ Mayor & $\begin{array}{c}0.0246^{* * *} \\
(0.0080)\end{array}$ & $\begin{array}{c}0.0256^{* *} \\
(0.0105)\end{array}$ & $\begin{array}{c}0.001 \\
(0.0109)\end{array}$ & $\begin{array}{c}-0.00776 \\
(0.0160)\end{array}$ & $\begin{array}{l}0.0135 * \\
(0.0077)\end{array}$ & $\begin{array}{l}0.0193^{*} \\
(0.0108)\end{array}$ \\
\hline $\mathrm{EV}^{*}$ Mayor & $\begin{array}{l}-0.00703 \\
(0.0150)\end{array}$ & $\begin{array}{l}-0.0261 \\
(0.0182)\end{array}$ & $\begin{array}{l}0.00999 \\
(0.0133)\end{array}$ & $\begin{array}{c}0.0133 \\
(0.0131)\end{array}$ & $\begin{array}{l}-0.0112 \\
(0.0089)\end{array}$ & $\begin{array}{c}-0.00824 \\
(0.0090)\end{array}$ \\
\hline EV(98)*Mayor & $\begin{array}{l}0.00845 \\
(0.0193)\end{array}$ & $\begin{array}{c}0.0404 \\
(0.0312)\end{array}$ & $\begin{array}{l}-0.0155 \\
(0.0183)\end{array}$ & $\begin{array}{c}0.0198 \\
(0.0195)\end{array}$ & $\begin{array}{c}-0.0289^{* *} \\
(0.0131)\end{array}$ & $\begin{array}{l}-0.0162 \\
(0.0132)\end{array}$ \\
\hline Constant & $\begin{array}{c}0.185^{* * *} \\
(0.0333)\end{array}$ & $\begin{array}{c}0.193^{* * *} \\
(0.0311)\end{array}$ & $\begin{array}{l}0.00874 \\
(0.0489)\end{array}$ & $\begin{array}{c}0.187^{* * *} * \\
(0.0339)\end{array}$ & $\begin{array}{l}-0.0351 \\
(0.0340)\end{array}$ & $\begin{array}{c}0.134^{* * * *} \\
(0.0214)\end{array}$ \\
\hline Observations & $\begin{array}{c}9375 \\
\text { Robust } \\
* * * \mathrm{p}\end{array}$ & $\begin{array}{c}9375 \\
\text { dard err } \\
01, * * \mathrm{p}\end{array}$ & $\begin{array}{c}9375 \\
\text { parenth } \\
5,{ }^{*} \mathrm{p}<0 .\end{array}$ & 9375 & 9375 & 9375 \\
\hline
\end{tabular}

Using average years of schooling, percentage of poor people, longevity HDI, inequality (Theil Index), children mortality, house infrastructure (telephone and electricity), percentage of woman, mayor party, mayor vote share on the last election, number of electors (as deviation from the threshold), state/municipality fixed effects,electors age composition (young and elderly), political engagement as controls 
Table 28: Electronic voting impact on the odds of voting for PSDB deputy over PSDB president

\begin{tabular}{|c|c|c|c|c|}
\hline \multirow{2}{*}{$\begin{array}{l}\text { Dep. Var.: Odds of voting for: } \\
\text { Regressions }\end{array}$} & \multicolumn{2}{|c|}{ Federal Deputy } & \multicolumn{2}{|c|}{ State Deputy } \\
\hline & $\overline{(11)}$ & $\overline{(2)}$ & (1) & (2) \\
\hline Electronic Voting (EV) & $\begin{array}{c}-0.00677 \\
(0.0396)\end{array}$ & & $\begin{array}{c}0.0189 \\
(0.0458)\end{array}$ & \\
\hline Year $=1998$ & $\begin{array}{c}0.126^{* * *} \\
(0.0063)\end{array}$ & $\begin{array}{c}0.122^{* * *} \\
(0.0070)\end{array}$ & $\begin{array}{c}0.133^{* * *} \\
(0.0063)\end{array}$ & $\begin{array}{c}0.137^{* * *} \\
(0.0068)\end{array}$ \\
\hline EV * Year $=1998[\mathrm{EV}(98)]$ & $\begin{array}{c}-0.0139 \\
(0.0568)\end{array}$ & $\begin{array}{c}0.00196 \\
(0.0626)\end{array}$ & $\begin{array}{l}-0.027 \\
(0.0551)\end{array}$ & $\begin{array}{c}-0.0609 \\
(0.0637)\end{array}$ \\
\hline Poor People (\%) & $\begin{array}{l}0.009 \\
(0.0098)\end{array}$ & & $\begin{array}{c}0.0260^{* * *} \\
(0.0084)\end{array}$ & \\
\hline EV $(98) *$ Poor People (\%) & $\begin{array}{c}0.0502 \\
(0.0501)\end{array}$ & $\begin{array}{c}0.0617 \\
(0.0489)\end{array}$ & $\begin{array}{l}-0.042 \\
(0.0545)\end{array}$ & $\begin{array}{c}-0.0172 \\
(0.0502)\end{array}$ \\
\hline Years of study & $\begin{array}{c}0.0406^{* * *} \\
(0.0097)\end{array}$ & & $\begin{array}{c}0.0267^{* * *} \\
(0.0090)\end{array}$ & \\
\hline EV*Poor People (\%) & $\begin{array}{c}-0.0199 \\
(0.0341)\end{array}$ & & $\begin{array}{c}0.0265 \\
(0.0428)\end{array}$ & \\
\hline Year $=1998^{*}$ Poor People $(\%)$ & $\begin{array}{c}0.0163 \\
(0.0119)\end{array}$ & $\begin{array}{c}0.0129 \\
(0.0122)\end{array}$ & $\begin{array}{c}0.0222^{* *} \\
(0.0107)\end{array}$ & $\begin{array}{c}0.0163 \\
(0.0110)\end{array}$ \\
\hline Mayor $(\mathrm{PSDB}=1)$ & $\begin{array}{c}-0.0305 \\
(0.0221)\end{array}$ & $\begin{array}{c}-0.119^{* * *} \\
(0.0385)\end{array}$ & $\begin{array}{c}0.0374 \\
(0.0234)\end{array}$ & $\begin{array}{c}-0.0559 \\
(0.0366)\end{array}$ \\
\hline Year $=1998^{*}$ Mayor $(\mathrm{PSDB}=1)$ & $\begin{array}{c}0.162^{* * *} \\
(0.0277)\end{array}$ & $\begin{array}{c}0.273^{* * *} \\
(0.0408)\end{array}$ & $\begin{array}{c}0.101^{* * *} \\
\quad(0.0279)\end{array}$ & $\begin{array}{c}0.203^{* * *} \\
(0.0379)\end{array}$ \\
\hline $\mathrm{EV}^{*}$ Mayor $(\mathrm{PSDB}=1)$ & $\begin{array}{l}0.101 \\
(0.0663)\end{array}$ & $\begin{array}{c}0.0849 \\
(0.0938)\end{array}$ & $\begin{array}{c}0.0908 \\
(0.0912)\end{array}$ & $\begin{array}{l}0.107 \\
(0.0836)\end{array}$ \\
\hline $\mathrm{EV}(98) *$ Mayor $(\mathrm{PSDB}=1)$ & $\begin{array}{c}-0.177^{* *} \\
(0.0856)\end{array}$ & $\begin{array}{c}-0.212^{*} \\
(0.1090)\end{array}$ & $\begin{array}{c}-0.202^{* *} \\
(0.1030)\end{array}$ & $\begin{array}{c}-0.221^{* * *} \\
(0.0815)\end{array}$ \\
\hline Constant & $\begin{array}{c}0.0653^{* * *} \\
(0.0248)\end{array}$ & $\begin{array}{c}0.111^{*} \\
(0.0614)\end{array}$ & $\begin{array}{c}0.0278 \\
(0.0264)\end{array}$ & $\begin{array}{c}-0.0439 \\
(0.0546)\end{array}$ \\
\hline $\begin{array}{l}\text { Robust sta } \\
* * * \mathrm{p}<\end{array}$ & $\begin{array}{c}9375 \\
\text { rd errors } \\
* * \quad p<0\end{array}$ & $\begin{array}{c}9375 \\
\text { arenth } \\
* \mathrm{p}<0.1\end{array}$ & 9375 & 9375 \\
\hline
\end{tabular}

Using average years of schooling, percentage of poor people, longevity HDI, inequality (Theil Index), children mortality, house infrastructure (telephone and electricity), percentage of woman, mayor party, mayor vote share on the last election, number of electors (as deviation from the threshold), state/municipality fixed effects,electors age composition (young and elderly), political engagement as controls 
Table 29: Electronic voting impact on the odds of voting for PSDB deputy (Party Code) over PSDB president

\begin{tabular}{|c|c|c|c|c|}
\hline \multirow{2}{*}{$\begin{array}{l}\text { Dep. Var.: Odds of voting for: } \\
\text { Regressions }\end{array}$} & \multicolumn{2}{|c|}{ Federal Deputy } & \multicolumn{2}{|c|}{ State Deputy } \\
\hline & (1) & (2) & (1) & (2) \\
\hline \multirow[t]{2}{*}{ Electronic Voting (EV) } & -0.0134 & & -0.00757 & \\
\hline & $(0.0271)$ & & $(0.0278)$ & \\
\hline \multirow[t]{2}{*}{ Year $=1998$} & $0.247^{* * *}$ & $0.238^{* * *}$ & $0.233^{* * *}$ & $0.227^{* * *}$ \\
\hline & $(0.0047)$ & $(0.0053)$ & $(0.0047)$ & $(0.0054)$ \\
\hline \multirow[t]{2}{*}{$\mathrm{EV} *$ Year $=1998[\mathrm{EV}(98)]$} & $-0.126 * * *$ & $-0.111^{* * *}$ & 0.0222 & 0.0223 \\
\hline & $(0.0326)$ & $(0.0352)$ & $(0.0363)$ & $(0.0411)$ \\
\hline \multirow[t]{2}{*}{ Poor People $(\%)$} & $-0.0161^{* *}$ & & $-0.0161^{* *}$ & \\
\hline & $(0.0065)$ & & $(0.0065)$ & \\
\hline \multirow[t]{2}{*}{ EV $(98) *$ Poor People $(\%)$} & $0.0586^{*}$ & $0.0819^{* * *}$ & $0.165^{* * *}$ & $0.179^{* * *}$ \\
\hline & $(0.0310)$ & $(0.0285)$ & $(0.0400)$ & $(0.0355)$ \\
\hline \multirow[t]{2}{*}{ Years of study } & -0.00655 & & 0.00366 & \\
\hline & $(0.0067)$ & & $(0.0064)$ & \\
\hline \multirow[t]{2}{*}{ EV*Poor People (\%) } & -0.0382 & & -0.0375 & \\
\hline & $(0.0246)$ & & $(0.0258)$ & \\
\hline \multirow{2}{*}{ Year $=1998^{*}$ Poor People $(\%)$} & $0.0424^{* * *}$ & $0.0426 * * *$ & $0.0481^{* * *}$ & $0.0500^{* * *}$ \\
\hline & $(0.0091)$ & $(0.0094)$ & $(0.0089)$ & $(0.0089)$ \\
\hline \multirow[t]{2}{*}{ Mayor $(\mathrm{PSDB}=1)$} & -0.0191 & $-0.133^{* * *}$ & -0.0114 & $-0.112^{* * *}$ \\
\hline & $(0.0172)$ & $(0.0286)$ & $(0.0191)$ & $(0.0296)$ \\
\hline \multirow[t]{2}{*}{ Year=1998*Mayor $(\mathrm{PSDB}=1)$} & $0.145^{* * *}$ & $0.278^{* * *}$ & $0.129 * * *$ & $0.250^{* * *}$ \\
\hline & $(0.0201)$ & $(0.0293)$ & $(0.0215)$ & $(0.0303)$ \\
\hline \multirow[t]{2}{*}{$\mathrm{EV}^{*}$ Mayor $(\mathrm{PSDB}=1)$} & -0.0079 & $0.108^{* *}$ & -0.0345 & 0.0368 \\
\hline & $(0.0371)$ & $(0.0425)$ & $(0.0388)$ & $(0.0535)$ \\
\hline \multirow{2}{*}{$\mathrm{EV}(98) *$ Mayor $(\mathrm{PSDB}=1)$} & $-0.141^{* * *}$ & $-0.222^{* * *}$ & -0.0497 & -0.0955 \\
\hline & $(0.0462)$ & $(0.0499)$ & $(0.0507)$ & $(0.0628)$ \\
\hline \multirow[t]{2}{*}{ Constant } & 0.0168 & $0.123^{* * *}$ & -0.0229 & 0.0565 \\
\hline & $(0.0187)$ & $(0.0391)$ & $(0.0159)$ & $(0.0396)$ \\
\hline Observations & 9375 & 9375 & 9375 & 9375 \\
\hline
\end{tabular}

Robust standard errors in parentheses $* * * \mathrm{p}<0.01, * * \mathrm{p}<0.05, * \mathrm{p}<0.1$

(1) Pooled regression; (2) Fixed Effects

Using average years of schooling, percentage of poor people, longevity HDI, inequality (Theil Index), children mortality, house infrastructure (telephone and electricity), percentage of woman, mayor party, mayor vote share on the last election, number of electors (as deviation from the threshold), state/municipality fixed effects, electors age composition (young and elderly), political engagement as controls 
Table 30: Electronic voting impact on the odds of voting for PT deputy over PT president

\begin{tabular}{|c|c|c|c|c|}
\hline \multirow{2}{*}{$\begin{array}{l}\text { Dep. Var.: Odds of voting for: } \\
\text { Regressions }\end{array}$} & \multicolumn{2}{|c|}{ Federal Deputy } & \multicolumn{2}{|c|}{ State Deputy } \\
\hline & (1) & (2) & $\overline{(1)}$ & (2) \\
\hline \multirow[t]{2}{*}{ Electronic Voting (EV) } & -0.0232 & & 0.0126 & \\
\hline & $(0.0436)$ & & $(0.0477)$ & \\
\hline \multirow[t]{2}{*}{ Year $=1998$} & $-0.0623^{* * *}$ & $-0.0509 * * *$ & $-0.0587 * * *$ & $-0.0490 * * *$ \\
\hline & $(0.0047)$ & $(0.0054)$ & $(0.0054)$ & $(0.0053)$ \\
\hline \multirow[t]{2}{*}{$\mathrm{EV} *$ Year $=1998[\mathrm{EV}(98)]$} & $0.189^{* * *}$ & $0.195^{* * *}$ & $0.104^{* *}$ & $0.151^{* * *}$ \\
\hline & $(0.0631)$ & $(0.0674)$ & $(0.0495)$ & $(0.0462)$ \\
\hline \multirow[t]{2}{*}{ Poor People (\%) } & $0.0242^{* *}$ & & 0.00556 & \\
\hline & $(0.0103)$ & & $(0.0129)$ & \\
\hline \multirow[t]{2}{*}{ EV $(98)^{*}$ Poor People $(\%)$} & 0.0253 & 0.0531 & 0.0364 & 0.0526 \\
\hline & $(0.0518)$ & $(0.0511)$ & $(0.0402)$ & $(0.0415)$ \\
\hline \multirow[t]{2}{*}{ Years of study } & $0.0860 * * *$ & & $0.0484^{* * *}$ & \\
\hline & $(0.0099)$ & & $(0.0116)$ & \\
\hline \multirow[t]{2}{*}{$\mathrm{EV}^{*}$ Poor People $(\%)$} & -0.0659 & & $-0.0736^{*}$ & \\
\hline & $(0.0429)$ & & $(0.0426)$ & \\
\hline \multirow[t]{2}{*}{ Year $=1998^{*}$ Poor People $(\%)$} & -0.0144 & -0.0131 & $-0.0294^{* *}$ & $-0.0291^{* *}$ \\
\hline & $(0.0094)$ & $(0.0091)$ & $(0.0123)$ & $(0.0121)$ \\
\hline \multirow[t]{2}{*}{ Mayor $(\mathrm{PT}=1)$} & $0.346^{* * *}$ & 0.047 & $0.413^{* * *}$ & -0.0767 \\
\hline & $(0.0527)$ & $(0.0430)$ & $(0.0959)$ & $(0.1050)$ \\
\hline \multirow[t]{2}{*}{ Year $=1998 *$ Mayor $(\mathrm{PT}=1)$} & 0.00273 & 0.0414 & 0.156 & 0.183 \\
\hline & $(0.0625)$ & $(0.0594)$ & $(0.1420)$ & $(0.1560)$ \\
\hline \multirow[t]{2}{*}{$\mathrm{EV}^{*}$ Mayor $(\mathrm{PT}=1)$} & 0.0637 & -0.0157 & -0.213 & 0.00125 \\
\hline & $(0.1250)$ & $(0.1910)$ & $(0.1430)$ & $(0.2360)$ \\
\hline \multirow[t]{2}{*}{$\mathrm{EV}(98) *$ Mayor $(\mathrm{PT}=1)$} & $-0.315^{* *}$ & -0.119 & -0.124 & -0.211 \\
\hline & $(0.1270)$ & $(0.1940)$ & $(0.1860)$ & $(0.2560)$ \\
\hline \multirow[t]{2}{*}{ Constant } & $0.611^{* * *}$ & $0.258 * * *$ & $0.487^{* * *}$ & $0.292^{* * *}$ \\
\hline & $(0.0718)$ & $(0.0474)$ & $(0.0674)$ & $(0.0447)$ \\
\hline Observations & 9375 & 9375 & 9375 & 9375 \\
\hline
\end{tabular}

(1) Pooled regression; (2) Fixed Effects

Using average years of schooling, percentage of poor people, longevity HDI, inequality (Theil Index), children mortality, house infrastructure (telephone and electricity), percentage of woman, mayor party,mayor vote share on the last election, number of electors (as deviation from the threshold), state/municipality fixed effects, electors age composition (young and elderly), political engagement as controls 
Table 31: Electronic voting impact on the odds of voting for PT deputy (Party Code) over PT president

\begin{tabular}{|c|c|c|c|c|}
\hline \multirow{2}{*}{$\begin{array}{l}\text { Dep. Var.: Odds of voting for: } \\
\text { Regressions }\end{array}$} & \multicolumn{2}{|c|}{ Federal Deputy } & \multicolumn{2}{|c|}{ State Deputy } \\
\hline & (1) & (2) & (1) & (2) \\
\hline \multirow[t]{2}{*}{ Electronic Voting (EV) } & $-0.184^{*}$ & & $-0.218^{*}$ & \\
\hline & $(0.0944)$ & & $(0.1140)$ & \\
\hline \multirow[t]{2}{*}{ Year $=1998$} & $-1.291^{* * *}$ & $-1.294^{* * *}$ & $-1.314^{* * *}$ & $-1.310^{* * *}$ \\
\hline & $(0.0218)$ & $(0.0248)$ & $(0.0245)$ & $(0.0279)$ \\
\hline \multirow[t]{2}{*}{ EV * Year $=1998[\mathrm{EV}(98)]$} & 0.0882 & 0.127 & -0.00241 & 0.0353 \\
\hline & $(0.1200)$ & $(0.1330)$ & $(0.1430)$ & $(0.1580)$ \\
\hline \multirow[t]{2}{*}{ Poor People (\%) } & $-0.194^{* * *}$ & & $-0.144^{* * *}$ & \\
\hline & $(0.0512)$ & & $(0.0524)$ & \\
\hline \multirow[t]{2}{*}{ EV $(98) *$ Poor People (\%) } & -0.0315 & -0.0027 & 0.0952 & 0.16 \\
\hline & $(0.1170)$ & $(0.1320)$ & $(0.1290)$ & $(0.1460)$ \\
\hline \multirow[t]{2}{*}{ Years of study } & -0.0664 & & -0.0147 & \\
\hline & $(0.0438)$ & & $(0.0520)$ & \\
\hline \multirow[t]{2}{*}{ EV*Poor People (\%) } & 0.0631 & & 0.0146 & \\
\hline & $(0.0898)$ & & $(0.1030)$ & \\
\hline \multirow[t]{2}{*}{ Year $=1998^{*}$ Poor People $(\%)$} & $0.102^{* *}$ & $0.110^{* *}$ & 0.0495 & 0.0289 \\
\hline & $(0.0463)$ & $(0.0468)$ & $(0.0494)$ & (0.0499) \\
\hline \multirow[t]{2}{*}{ Mayor $(\mathrm{PT}=1)$} & -0.142 & -0.155 & -0.127 & -0.116 \\
\hline & $(0.1020)$ & $(0.1480)$ & $(0.1150)$ & $(0.1350)$ \\
\hline \multirow[t]{2}{*}{ Year $=1998^{*}$ Mayor $(\mathrm{PT}=1)$} & $0.274^{* *}$ & $0.467^{* * *}$ & $0.259^{* *}$ & $0.481^{* * *}$ \\
\hline & $(0.1110)$ & $(0.1620)$ & $(0.1230)$ & $(0.1530)$ \\
\hline \multirow[t]{2}{*}{$\mathrm{EV}^{*}$ Mayor $(\mathrm{PT}=1)$} & 0.0413 & $0.581^{* *}$ & 0.0344 & $0.474^{*}$ \\
\hline & $(0.1700)$ & $(0.2520)$ & $(0.1760)$ & $(0.2570)$ \\
\hline \multirow[t]{2}{*}{$\mathrm{EV}(98) *$ Mayor $(\mathrm{PT}=1)$} & -0.124 & $-0.581^{* *}$ & -0.114 & -0.411 \\
\hline & $(0.1970)$ & $(0.2950)$ & $(0.2060)$ & (0.3010) \\
\hline \multirow[t]{2}{*}{ Constant } & $2.048^{* * *}$ & $2.396^{* * *}$ & $2.161^{* * *}$ & $2.157^{* * *}$ \\
\hline & $(0.2030)$ & $(0.1660)$ & $(0.1700)$ & $(0.1880)$ \\
\hline Observations & 9375 & 9375 & 9375 & 9375 \\
\hline
\end{tabular}

(1) Pooled regression; (2) Fixed Effects

Using average years of schooling, percentage of poor people, longevity HDI, inequality (Theil Index), children mortality, house infrastructure (telephone and electricity), percentage of woman, mayor party,mayor vote share on the last election, number of electors (as deviation from the threshold), state/municipality fixed effects,electors age composition (young and elderly), political engagement as controls 
Table 32: Paper Ballot impact on bookend candidates (around discontinuity threshold \pm 20,000)

\begin{tabular}{|c|c|c|c|c|c|c|}
\hline Dep. Var.: Bookend Discontinuity & \multicolumn{3}{|c|}{ Lula "bookends" } & \multicolumn{3}{|c|}{ FHC "bookends" } \\
\hline Regressions & (1) & $(2)$ & (3) & (1) & $(2)$ & (3) \\
\hline Paper Ballot & $\begin{array}{c}0.00737^{* * *} \\
(0.0005)\end{array}$ & $\begin{array}{c}0.00698^{* * *} \\
(0.0011)\end{array}$ & $\begin{array}{c}0.00707^{* * *} \\
(0.0012)\end{array}$ & $\begin{array}{c}0.00620^{* * *} \\
(0.0009)\end{array}$ & $\begin{array}{c}0.00247 \\
(0.0018)\end{array}$ & $\begin{array}{c}0.00334^{*} \\
(0.0018)\end{array}$ \\
\hline "Book" Vote Share & & $\begin{array}{c}-0.00172 \\
(0.0024)\end{array}$ & $\begin{array}{c}-0.00144 \\
(0.0020)\end{array}$ & & $\begin{array}{l}1.494 \\
(0.9890)\end{array}$ & $\begin{array}{l}1.528 \\
(1.0080)\end{array}$ \\
\hline "Book" Vote Share $*($ PaperBallot==1) & & $\begin{array}{c}0.00837^{* *} \\
(0.0031)\end{array}$ & $\begin{array}{c}0.00968^{* * *} \\
(0.0029)\end{array}$ & & $\begin{array}{l}-0.052 \\
(0.9350)\end{array}$ & $\begin{array}{r}-0.191 \\
(0.9560)\end{array}$ \\
\hline Paper Ballot*Years of schooling & & & $\begin{array}{c}-0.00176^{* * *} \\
(0.0004)\end{array}$ & & & $\begin{array}{c}-0.00126^{* * *} \\
(0.0003)\end{array}$ \\
\hline Constant & $\begin{array}{c}-0.000789 \\
(0.0007)\end{array}$ & $\begin{array}{c}-0.00208^{* *} \\
(0.0009)\end{array}$ & $\begin{array}{c}-0.00211^{*} \\
(0.0010)\end{array}$ & $\begin{array}{c}0.00155 \\
(0.0015)\end{array}$ & $\begin{array}{c}-0.00413^{* *} \\
(0.0020)\end{array}$ & $\begin{array}{c}-0.00410^{*} \\
(0.0021)\end{array}$ \\
\hline Observations & 544 & 544 & 544 & 544 & 544 & 544 \\
\hline
\end{tabular}

Using average years of schooling, percentage of poor people, longevity HDI, inequality (Theil Index), children mortality, house infrastructure (telephone and electricity), percentage of woman, mayor party,mayor vote share on the last election, number of electors (as deviation from the threshold), state/municipality fixed effects, electors age composition (young and elderly), political engagement as controls

Table 33: Paper Ballot impact on bookend candidates - 1994

\begin{tabular}{|c|c|c|c|c|c|c|}
\hline Dep. Var.: Bookend & \multicolumn{3}{|c|}{ Lula "bookends" } & \multicolumn{3}{|c|}{ FHC "bookends" } \\
\hline Regressions & (1) & 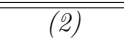 & 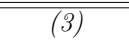 & (1) & (2) & (3) \\
\hline Paper Ballot & $\begin{array}{c}0.00462 \\
(0.0028)\end{array}$ & $\begin{array}{c}-0.00282 \\
(0.0050)\end{array}$ & $\begin{array}{c}-0.00298 \\
(0.0050)\end{array}$ & $\begin{array}{c}0.000608 \\
(0.0031)\end{array}$ & $\begin{array}{c}0.0151^{* *} \\
(0.0056)\end{array}$ & $\begin{array}{c}0.0137^{* *} \\
(0.0057)\end{array}$ \\
\hline "Book" Vote Share & & $\begin{array}{c}-0.0392^{*} \\
(0.0206)\end{array}$ & $\begin{array}{c}-0.0394^{*} \\
(0.0205)\end{array}$ & & $\begin{array}{c}-0.0983 \\
(0.0987)\end{array}$ & $\begin{array}{l}-0.119 \\
(0.0977)\end{array}$ \\
\hline "Book" Vote Share $*($ PaperBallot $==1)$ & & $\begin{array}{c}0.0295^{* *} \\
(0.0127)\end{array}$ & $\begin{array}{c}0.0295^{* *} \\
(0.0126)\end{array}$ & & $\begin{array}{l}-0.149 \\
(0.0877)\end{array}$ & $\begin{array}{c}-0.0831 \\
(0.0680)\end{array}$ \\
\hline Paper Ballot*Years of schooling & & & $\begin{array}{c}0.000629 \\
(0.0014)\end{array}$ & & & $\begin{array}{c}-0.00856^{*} \\
(0.0045)\end{array}$ \\
\hline Constant & $\begin{array}{c}0.0185^{* * *} \\
(0.0059)\end{array}$ & $\begin{array}{c}0.0312^{* * *} \\
(0.0043)\end{array}$ & $\begin{array}{c}0.0312^{* * *} \\
(0.0043)\end{array}$ & $\begin{array}{c}0.0942^{* * *} \\
(0.0106)\end{array}$ & $\begin{array}{c}0.0997 * * * \\
(0.0066)\end{array}$ & $\begin{array}{c}0.101^{* * *} \\
(0.0065)\end{array}$ \\
\hline Obser & 4305 & 4305 & 4305 & 4305 & 4305 & 4305 \\
\hline
\end{tabular}

Robust standard errors in parentheses

$* * * \mathrm{p}<0.01, * * \mathrm{p}<0.05, * \mathrm{p}<0.1$

Using average years of schooling, percentage of poor people, longevity HDI, inequality (Theil Index), children mortality, house infrastructure (telephone and electricity), percentage of woman, mayor party, mayor vote share on the last election, number of electors (as deviation from the threshold), state/municipality fixed effects, electors age composition (young and elderly), political engagement as controls 
Table 34: Paper Ballot impact on bookend candidates (around discontinuity threshold \pm $20,000-1994)$

\begin{tabular}{|c|c|c|c|c|c|c|}
\hline Dep. Var.: Bookend Discontinuity & Lu & la "booken & ds" & & C "booker & ids" \\
\hline Regressions & (1) & (2) & (3) & (1) & (2) & (3) \\
\hline Paper Ballot & $\begin{array}{c}0.00368 \\
(0.0038)\end{array}$ & $\begin{array}{c}0.00466 \\
(0.0077)\end{array}$ & $\begin{array}{c}0.00416 \\
(0.0073)\end{array}$ & $\begin{array}{c}0.00136 \\
(0.0031)\end{array}$ & $\begin{array}{c}0.00145 \\
(0.0044)\end{array}$ & $\begin{array}{c}0.00000378 \\
(0.0047)\end{array}$ \\
\hline "Book" Vote Share & & $\begin{array}{c}-0.0242 \\
(0.0193)\end{array}$ & $\begin{array}{c}-0.0246 \\
(0.0196)\end{array}$ & & $\begin{array}{l}-0.035 \\
(0.0455)\end{array}$ & $\begin{array}{c}-0.0593 \\
(0.0489)\end{array}$ \\
\hline "Book" Vote Share * (PaperBallot==1) & & $\begin{array}{c}0.000747 \\
(0.0261)\end{array}$ & $\begin{array}{c}0.00107 \\
(0.0255)\end{array}$ & & $\begin{array}{c}-0.0485 \\
(0.0920)\end{array}$ & $\begin{array}{c}0.00677 \\
(0.1010)\end{array}$ \\
\hline Paper Ballot*Years of schooling & & & $\begin{array}{c}0.00187 \\
(0.0027)\end{array}$ & & & $\begin{array}{c}-0.00482 \\
(0.0034)\end{array}$ \\
\hline Constant & $\begin{array}{c}0.0162^{* * *} \\
(0.0037) \\
\end{array}$ & $\begin{array}{c}0.0147^{* * *} \\
(0.0045) \\
\end{array}$ & $\begin{array}{c}0.0150^{* * *} \\
(0.0048) \\
\end{array}$ & $\begin{array}{c}0.0675^{* * *} \\
(0.0080) \\
\end{array}$ & $\begin{array}{c}0.0704^{* * *} \\
(0.0145) \\
\end{array}$ & $\begin{array}{c}0.0712^{\text {*** }} \\
(0.0139)\end{array}$ \\
\hline Observations & 483 & 483 & 483 & 483 & 483 & 483 \\
\hline
\end{tabular}

Using average years of schooling, percentage of poor people, longevity HDI, inequality (Theil Index), children mortality, house infrastructure (telephone and electricity), percentage of woman, mayor party, mayor vote share on the last election, number of electors (as deviation from the threshold), state/municipality fixed effects,electors age composition (young and elderly), political engagement as controls

Table 35: Electronic voting impact on municpality resource allocation (99 vs 98 - IBGE)

\begin{tabular}{|c|c|c|c|c|c|c|c|c|c|}
\hline \multirow{2}{*}{$\begin{array}{l}\text { Regressions } \\
\text { Transportation (\%) }\end{array}$} & \multicolumn{3}{|c|}{ Full Sample } & \multicolumn{3}{|c|}{$\begin{array}{c}\text { Full Sample } \\
\text { Threshold } \pm 20 \mathrm{k}\end{array}$} & \multicolumn{3}{|c|}{ Threshold $\pm 15 \mathrm{k}$} \\
\hline & $\begin{array}{c}-0.00554 \\
(0.0063)\end{array}$ & $\begin{array}{c}-0.00697 \\
(0.0061)\end{array}$ & $\begin{array}{c}-0.0143 \\
(0.0150)\end{array}$ & $\begin{array}{c}-0.0123 \\
(0.0153)\end{array}$ & $\begin{array}{c}-0.0135 \\
(0.0165)\end{array}$ & $\begin{array}{c}-0.00978 \\
(0.0174)\end{array}$ & $\begin{array}{c}-0.00733 \\
(0.0174)\end{array}$ & $\begin{array}{c}-0.0118 \\
(0.0183)\end{array}$ & $\begin{array}{c}-0.0201 \\
(0.0217)\end{array}$ \\
\hline Health $(\%)$ & $\begin{array}{c}0.0184^{* *} \\
(0.0079)\end{array}$ & $\begin{array}{c}0.0187^{* *} \\
(0.0077)\end{array}$ & $\begin{array}{c}0.0331 \\
(0.0212)\end{array}$ & $\begin{array}{c}0.0362 \\
(0.0214)\end{array}$ & $\begin{array}{l}0.0307 \\
(0.0190)\end{array}$ & $\begin{array}{l}0.017 \\
(0.0296)\end{array}$ & $\begin{array}{c}0.0241 \\
(0.0300)\end{array}$ & $\begin{array}{l}0.0158 \\
(0.0275)\end{array}$ & $\begin{array}{c}-0.000512 \\
(0.0401)\end{array}$ \\
\hline Social Security (\%) & $\begin{array}{c}-0.00299 \\
(0.0045)\end{array}$ & $\begin{array}{c}-0.00313 \\
(0.0046)\end{array}$ & $\begin{array}{l}-0.015 \\
(0.0092)\end{array}$ & $\begin{array}{c}-0.0128 \\
(0.0100)\end{array}$ & $\begin{array}{c}-0.00867 \\
(0.0103)\end{array}$ & $\begin{array}{c}-0.00752 \\
(0.0105)\end{array}$ & $\begin{array}{c}-0.00503 \\
(0.0114)\end{array}$ & $\begin{array}{c}-0.00252 \\
(0.0119)\end{array}$ & $\begin{array}{c}-0.00214 \\
(0.0148)\end{array}$ \\
\hline Legislative Functions (\%) & $\begin{array}{c}0.00577 \\
(0.0072)\end{array}$ & $\begin{array}{c}0.00605 \\
(0.0073)\end{array}$ & $\begin{array}{c}0.0088 \\
(0.0091)\end{array}$ & $\begin{array}{c}0.00511 \\
(0.0092)\end{array}$ & $\begin{array}{c}0.00521 \\
(0.0097)\end{array}$ & $\begin{array}{c}0.00793 \\
(0.0102)\end{array}$ & $\begin{array}{c}0.0051 \\
(0.0111)\end{array}$ & $\begin{array}{c}0.00842 \\
(0.0108)\end{array}$ & $\begin{array}{c}0.0166 \\
(0.0136)\end{array}$ \\
\hline Housing (\%) & $\begin{array}{c}-0.00768 \\
(0.0091)\end{array}$ & $\begin{array}{c}-0.00745 \\
(0.0089)\end{array}$ & $\begin{array}{l}-0.026 \\
(0.0227)\end{array}$ & $\begin{array}{c}-0.0248 \\
(0.0237)\end{array}$ & $\begin{array}{c}-0.0246 \\
(0.0249)\end{array}$ & $\begin{array}{c}-0.0287 \\
(0.0220)\end{array}$ & $\begin{array}{c}-0.0352 \\
(0.0251)\end{array}$ & $\begin{array}{c}-0.0307 \\
(0.0235)\end{array}$ & $\begin{array}{l}-0.0299 \\
(0.0248)\end{array}$ \\
\hline Education (\%) & $\begin{array}{c}-0.0125 \\
(0.0128)\end{array}$ & $\begin{array}{l}-0.011 \\
(0.0123)\end{array}$ & $\begin{array}{l}-0.024 \\
(0.0177)\end{array}$ & $\begin{array}{c}-0.0234 \\
(0.0188)\end{array}$ & $\begin{array}{c}-0.0195 \\
(0.0181)\end{array}$ & $\begin{array}{c}-0.0296 \\
(0.0232)\end{array}$ & $\begin{array}{c}-0.0315 \\
(0.0253)\end{array}$ & $\begin{array}{c}-0.0312 \\
(0.0248)\end{array}$ & $\begin{array}{c}0.00169 \\
(0.0186)\end{array}$ \\
\hline Agriculture (\%) & $\begin{array}{c}0.00194 \\
(0.0026)\end{array}$ & $\begin{array}{c}0.00127 \\
(0.0027)\end{array}$ & $\begin{array}{c}0.00494 \\
(0.0041)\end{array}$ & $\begin{array}{c}0.00609 \\
(0.0045)\end{array}$ & $\begin{array}{c}0.00752 \\
(0.0046)\end{array}$ & $\begin{array}{c}0.00486 \\
(0.0041)\end{array}$ & $\begin{array}{c}0.00569 \\
(0.0052)\end{array}$ & $\begin{array}{c}0.00639 \\
(0.0041)\end{array}$ & $\begin{array}{c}0.00104 \\
(0.0076)\end{array}$ \\
\hline Administration (\%) & $\begin{array}{c}0.0104 \\
(0.0120)\end{array}$ & $\begin{array}{c}0.0101 \\
(0.0124)\end{array}$ & $\begin{array}{c}0.0265 \\
(0.0168)\end{array}$ & $\begin{array}{c}0.02 \\
(0.0172)\end{array}$ & $\begin{array}{l}0.0125 \\
(0.0181)\end{array}$ & $\begin{array}{c}0.0314 \\
(0.0209)\end{array}$ & $\begin{array}{c}0.0289 \\
(0.0220)\end{array}$ & $\begin{array}{l}0.0262 \\
(0.0233)\end{array}$ & $\begin{array}{c}0.0327 \\
(0.0261)\end{array}$ \\
\hline Total Spent & $\begin{array}{c}0.0155 \\
(0.0620)\end{array}$ & $\begin{array}{c}0.0156 \\
(0.0654)\end{array}$ & $\begin{array}{c}0.0517 \\
(0.1040)\end{array}$ & $\begin{array}{c}0.0447 \\
(0.1040)\end{array}$ & $\begin{array}{c}0.0473 \\
(0.1070)\end{array}$ & $\begin{array}{c}0.0378 \\
(0.1060)\end{array}$ & $\begin{array}{c}0.0508 \\
(0.1080)\end{array}$ & $\begin{array}{c}0.0563 \\
(0.1240)\end{array}$ & $\begin{array}{c}-0.155^{*} \\
(0.0884) \\
\end{array}$ \\
\hline $\begin{array}{l}\text { Observations } \\
\text { Controls }\end{array}$ & 4881 & 4881 & 513 & 513 & 513 & 324 & 324 & 324 & 183 \\
\hline State & No & Yes & Yes & No & Yes & Yes & No & Yes & No \\
\hline Mayor Party & No & $\begin{array}{l}\text { No } \\
\text { Robu } \\
\quad * *\end{array}$ & $\begin{array}{l}\text { Yes } \\
\text { tandal } \\
<0.01,\end{array}$ & $\begin{array}{l}\text { No } \\
\text { rrors i } \\
\mathrm{p}<0.0\end{array}$ & $\begin{array}{l}\text { No } \\
\text { renthes } \\
p<0.1\end{array}$ & Yes & No & No & Yes \\
\hline
\end{tabular}

Using average years of schooling, percentage of poor people, longevity HDI, inequality (Theil Index), children mortality, house infrastrutucture (telephone and eletricity), percentage of woman, mayor party, mayor vote share on the last election, number of electors (as deviation from the trheshold), state/municipality fixed effects,electors age composition (young and elederly), political engagement as controls 
Table 36: Electronic voting impact on municpality resource allocation (99 vs 98 - IBGE)

\begin{tabular}{|c|c|c|c|c|c|c|c|c|c|c|}
\hline \multirow{3}{*}{$\begin{array}{l}\text { Regressions } \\
\text { Transportation (\%) }\end{array}$} & \multirow{3}{*}{$\begin{array}{l}\text { Full Sample } \\
\\
-0.00697 \\
(0.0061)\end{array}$} & \multicolumn{9}{|c|}{ Top Fractionalization } \\
\hline & & \multicolumn{3}{|c|}{ Full Sample } & \multicolumn{3}{|c|}{ Threshold $\pm 20 \mathrm{k}$} & \multicolumn{3}{|c|}{ Threshold $\pm 15 \mathrm{k}$} \\
\hline & & $\begin{array}{c}-0.00221 \\
(0.0080)\end{array}$ & $\begin{array}{c}0.000866 \\
(0.0090)\end{array}$ & $\begin{array}{c}-0.0000944 \\
(0.0094)\end{array}$ & $\begin{array}{c}0.0066 \\
(0.0163)\end{array}$ & $\begin{array}{c}0.00997 \\
(0.0193)\end{array}$ & $\begin{array}{c}0.0121 \\
(0.0202)\end{array}$ & $\begin{array}{c}0.0152 \\
(0.0171)\end{array}$ & $\begin{array}{c}0.0191 \\
(0.0176)\end{array}$ & $\begin{array}{l}0.0187 \\
(0.0184)\end{array}$ \\
\hline Health $(\%)$ & $\begin{array}{c}0.0187^{* *} \\
(0.0077)\end{array}$ & $\begin{array}{c}-0.00221 \\
(0.0158)\end{array}$ & $\begin{array}{c}0.00137 \\
(0.0142)\end{array}$ & $\begin{array}{r}0.0047 \\
(0.0143)\end{array}$ & $\begin{array}{c}-0.0455 \\
(0.0356)\end{array}$ & $\begin{array}{c}-0.0414 \\
(0.0362)\end{array}$ & $\begin{array}{c}-0.0532 \\
(0.0353)\end{array}$ & $\begin{array}{c}-0.0488 \\
(0.0312)\end{array}$ & $\begin{array}{c}-0.0371 \\
(0.0269)\end{array}$ & $\begin{array}{c}-0.0546 \\
(0.0360)\end{array}$ \\
\hline Social Security (\%) & $\begin{array}{c}-0.00313 \\
(0.0046)\end{array}$ & $\begin{array}{c}-0.0068 \\
(0.0063)\end{array}$ & $\begin{array}{c}-0.00389 \\
(0.0071)\end{array}$ & $\begin{array}{c}-0.00337 \\
(0.0073)\end{array}$ & $\begin{array}{c}0.0144^{*} \\
(0.0079)\end{array}$ & $\begin{array}{c}0.0243^{* *} \\
(0.0101)\end{array}$ & $\begin{array}{c}0.0240^{* *} \\
(0.0087)\end{array}$ & $\begin{array}{c}0.0220^{* *} \\
(0.0095)\end{array}$ & $\begin{array}{c}0.0245^{*} \\
(0.0129)\end{array}$ & $\begin{array}{c}0.0192^{*} \\
(0.0104)\end{array}$ \\
\hline Legislative Functions (\%) & $\begin{array}{c}0.00605 \\
(0.0073)\end{array}$ & $\begin{array}{c}-0.00363 \\
(0.0073)\end{array}$ & $\begin{array}{c}-0.000931 \\
(0.0068)\end{array}$ & $\begin{array}{c}-0.00117 \\
(0.0071)\end{array}$ & $\begin{array}{c}0.00281 \\
(0.0108)\end{array}$ & $\begin{array}{c}-0.00473 \\
(0.0098)\end{array}$ & $\begin{array}{c}0.000757 \\
(0.0098)\end{array}$ & $\begin{array}{c}0.00894 \\
(0.0137)\end{array}$ & $\begin{array}{c}0.00487 \\
(0.0159)\end{array}$ & $\begin{array}{c}0.0138 \\
(0.0177)\end{array}$ \\
\hline Housing $(\%)$ & $\begin{array}{c}-0.00745 \\
(0.0089)\end{array}$ & $\begin{array}{c}0.00722 \\
(0.0177)\end{array}$ & $\begin{array}{c}0.000461 \\
(0.0168)\end{array}$ & $\begin{array}{c}-0.00126 \\
(0.0172)\end{array}$ & $\begin{array}{c}-0.0144 \\
(0.0237)\end{array}$ & $\begin{array}{c}-0.0314 \\
(0.0250)\end{array}$ & $\begin{array}{c}-0.0271 \\
(0.0289)\end{array}$ & $\begin{array}{c}-0.0169 \\
(0.0318)\end{array}$ & $\begin{array}{c}-0.0409 \\
(0.0266)\end{array}$ & $\begin{array}{c}-0.00438 \\
(0.0434)\end{array}$ \\
\hline Education (\%) & $\begin{array}{l}-0.011 \\
(0.0123)\end{array}$ & $\begin{array}{c}-0.0209 \\
(0.0134)\end{array}$ & $\begin{array}{l}-0.022 \\
(0.0135)\end{array}$ & $\begin{array}{c}-0.0189 \\
(0.0129)\end{array}$ & $\begin{array}{c}-0.00252 \\
(0.0193)\end{array}$ & $\begin{array}{c}0.00131 \\
(0.0217)\end{array}$ & $\begin{array}{c}0.00953 \\
(0.0191)\end{array}$ & $\begin{array}{c}-0.0391^{* *} \\
(0.0181)\end{array}$ & $\begin{array}{c}-0.0343 \\
(0.0245)\end{array}$ & $\begin{array}{c}-0.0523^{* *} \\
(0.0209)\end{array}$ \\
\hline Agriculture (\%) & $\begin{array}{c}0.00127 \\
(0.0027)\end{array}$ & $\begin{array}{c}0.00392 \\
(0.0031)\end{array}$ & $\begin{array}{c}0.00302 \\
(0.0032)\end{array}$ & $\begin{array}{c}0.00101 \\
(0.0024)\end{array}$ & $\begin{array}{c}0.00789 \\
(0.0068)\end{array}$ & $\begin{array}{c}0.00773 \\
(0.0093)\end{array}$ & $\begin{array}{c}0.00679 \\
(0.0103)\end{array}$ & $\begin{array}{c}0.00998 \\
(0.0088)\end{array}$ & $\begin{array}{c}0.00448 \\
(0.0097)\end{array}$ & $\begin{array}{c}0.0118 \\
(0.0103)\end{array}$ \\
\hline Administration (\%) & $\begin{array}{l}0.0101 \\
(0.0124)\end{array}$ & $\begin{array}{c}0.0294 \\
(0.0197)\end{array}$ & $\begin{array}{c}0.0296 \\
(0.0208)\end{array}$ & $\begin{array}{c}0.0272 \\
(0.0218)\end{array}$ & $\begin{array}{c}0.0479^{* *} \\
(0.0206)\end{array}$ & $\begin{array}{c}0.0479^{*} \\
(0.0269)\end{array}$ & $\begin{array}{l}0.045 \\
(0.0316)\end{array}$ & $\begin{array}{c}0.0679^{* *} \\
(0.0277)\end{array}$ & $\begin{array}{c}0.0809^{* * *} \\
(0.0278)\end{array}$ & $\begin{array}{c}0.0734^{* *} \\
(0.0341)\end{array}$ \\
\hline Total Spent & $\begin{array}{c}0.0156 \\
(0.0654)\end{array}$ & $\begin{array}{l}0.124 \\
(0.0923)\end{array}$ & $\begin{array}{l}0.103 \\
(0.0859)\end{array}$ & $\begin{array}{l}0.105 \\
(0.0831)\end{array}$ & $\begin{array}{l}0.191 \\
(0.2080)\end{array}$ & $\begin{array}{l}0.103 \\
(0.1890)\end{array}$ & $\begin{array}{c}0.0955 \\
(0.1930)\end{array}$ & $\begin{array}{l}0.123 \\
(0.1880)\end{array}$ & $\begin{array}{c}0.0166 \\
(0.1620)\end{array}$ & $\begin{array}{l}0.169 \\
(0.2140)\end{array}$ \\
\hline $\begin{array}{l}\text { Observations } \\
\text { Controls }\end{array}$ & 4881 & 2687 & 2687 & 2687 & 264 & 264 & 264 & 163 & 163 & 163 \\
\hline State & Yes & No & Yes & Yes & No & Yes & Yes & No & Yes & No \\
\hline Mayor Party & Yes & No & No & Yes & No & No & Yes & No & No & Yes \\
\hline
\end{tabular}

Using average years of schooling, percentage of poor people, longevity HDI, inequality (Theil Index), children mortality, house infrastructure (telephone and electricity), percentage of woman, mayor party,mayor vote share on the last election, number of electors (as deviation from the threshold), state/municipality fixed effects, electors age composition (young and elderly), political engagement as controls 
Table 37: Electronic voting impact on municpality revenues (99 vs 98 - IBGE)

\begin{tabular}{|c|c|c|c|c|c|c|c|c|c|c|}
\hline \multirow{2}{*}{\multicolumn{2}{|c|}{ Full Sample }} & \multicolumn{9}{|c|}{ Bottom Fractionalization } \\
\hline & & \multicolumn{3}{|c|}{ Full Sample } & \multicolumn{3}{|c|}{ Threshold $\pm 20 \mathrm{k}$} & \multicolumn{3}{|c|}{ Threshold $\pm 15 \mathrm{k}$} \\
\hline "Tax Revenues (\%) & $\begin{array}{l}0.00554 \\
(0.0055)\end{array}$ & $\begin{array}{l}0.0044 \\
(0.0087)\end{array}$ & $\begin{array}{l}0.00227 \\
0.0093)\end{array}$ & $\begin{array}{l}0.00157 \\
0.0107)\end{array}$ & 0.000706 & $\begin{array}{c}-0.00398 \\
(0.0129)\end{array}$ & $\begin{array}{l}-0.012 \\
(0.0109)\end{array}$ & -0.00938 & -0.00998 & -0.0106 \\
\hline $\operatorname{IPTU}(\%)$ & -0.00406 & 0.00578 & 0.00938 & 0.00861 & -0.0107 & -0.012 & 0.00805 & -0.0134 & -0.00394 & 0.00319 \\
\hline $\operatorname{ITBI}(\%)$ & $\begin{array}{c}(0.0106) \\
0.000304 \\
(0.0081)\end{array}$ & $\begin{array}{c}(0.0169) \\
-0.00892 \\
(0.0076)\end{array}$ & $\begin{array}{c}(0.0150) \\
-0.000369\end{array}$ & $\begin{array}{c}(0.0148) \\
-0.00101\end{array}$ & $\begin{array}{c}(0.0286) \\
-0.0208 \\
(0.0145)\end{array}$ & $\begin{array}{c}(0.0325) \\
-0.0183 \\
\end{array}$ & $\begin{array}{c}(0.0376) \\
-0.0136 \\
(0.0135)\end{array}$ & $\begin{array}{l}(0.0367) \\
-0.0174 \\
-(0.010)\end{array}$ & $\begin{array}{c}(0.0366) \\
-0.0268^{* *}\end{array}$ & $\begin{array}{c}(0.0447) \\
-0.00287\end{array}$ \\
\hline ISS (\%) & $\begin{array}{l}(0.0081) \\
0.0173 \\
(0.0192)\end{array}$ & $\begin{array}{c}(0.0076) \\
-0.00262 \\
(0.0200)\end{array}$ & $\begin{array}{c}(0.0067) \\
-0.00831 \\
(0.0218)\end{array}$ & $\begin{array}{c}(0.0070) \\
-0.00842 \\
(0.0209)\end{array}$ & $\begin{array}{c}(0.0145) \\
0.00644 \\
(0.0460)\end{array}$ & $\begin{array}{l}(0.0137) \\
0.0139 \\
(0.0560)\end{array}$ & $\begin{array}{c}(0.0135) \\
-0.00832 \\
(0.0496)\end{array}$ & $\begin{array}{l}(0.0120) \\
0.0316 \\
(0.0613)\end{array}$ & $\begin{array}{l}(0.0097) \\
0.0384 \\
(0.0683)\end{array}$ & $\begin{array}{c}(0.0162) \\
0.00284 \\
(0.0593)\end{array}$ \\
\hline Fees (\%) & $\begin{array}{c}-0.0194 \\
(0.0144)\end{array}$ & $\begin{array}{c}-0.0389^{*} \\
(0.0218)\end{array}$ & $\begin{array}{r}-0.0402 \\
(0.0238)\end{array}$ & $\begin{array}{c}-0.0406^{*} \\
(0.0223)\end{array}$ & $\begin{array}{c}-0.0609 \\
(0.0362)\end{array}$ & $\begin{array}{c}-0.0722^{*} \\
(0.0364)\end{array}$ & $\begin{array}{c}-0.0775 \\
(0.0480)\end{array}$ & $\begin{array}{c}-0.0884 \\
(0.0670)\end{array}$ & $\begin{array}{l}-0.105 \\
(0.0709)\end{array}$ & $\begin{array}{l}-0.123 \\
(0.0785)\end{array}$ \\
\hline Other taxes (\%) & $\begin{array}{c}0.00592 \\
(0.0199)\end{array}$ & $\begin{array}{c}0.0446^{* *} \\
(0.0166)\end{array}$ & $\begin{array}{c}0.0395 * * \\
(0.0174)\end{array}$ & $\begin{array}{c}0.0415^{* *} \\
(0.0170)\end{array}$ & $\begin{array}{c}0.0860^{* *} \\
(0.0376)\end{array}$ & $\begin{array}{c}0.0886^{* *} \\
(0.0387)\end{array}$ & $\begin{array}{c}0.0914^{*} \\
(0.0498)\end{array}$ & $\begin{array}{l}0.0876 \\
(0.0620)\end{array}$ & $\begin{array}{l}0.0976 \\
(0.0658)\end{array}$ & $\begin{array}{c}0.12 \\
(0.0848)\end{array}$ \\
\hline Contribuitions (\%) & $\begin{array}{c}-0.000644 \\
(0.0037)\end{array}$ & $\begin{array}{c}-0.00564^{* *} \\
(0.0026)\end{array}$ & $\begin{array}{c}-0.00660^{* * *} \\
(0.0016)\end{array}$ & $\begin{array}{c}-0.00774^{* * *} \\
(0.0018)\end{array}$ & $\begin{array}{c}-0.0166^{* * *} \\
(0.0054)\end{array}$ & $\begin{array}{c}-0.0173^{* * *} \\
(0.0056)\end{array}$ & $\begin{array}{c}-0.0177^{* *} \\
(0.0074)\end{array}$ & $\begin{array}{c}-0.0141^{* *} \\
(0.0065)\end{array}$ & $\begin{array}{c}-0.0146^{*} \\
(0.0077)\end{array}$ & $\begin{array}{l}-0.0121 \\
(0.0087)\end{array}$ \\
\hline Patrimonial Revenue (\%) & $\begin{array}{c}-0.000965 \\
(0.0022)\end{array}$ & $\begin{array}{c}-0.00084 \\
(0.0023)\end{array}$ & $\begin{array}{c}-0.000947 \\
(0.0023)\end{array}$ & $\begin{array}{c}-0.00052 \\
(0.0024)\end{array}$ & $\begin{array}{l}0.0026 \\
(0.0025)\end{array}$ & $\begin{array}{c}0.00268 \\
(0.0030)\end{array}$ & $\begin{array}{c}-0.00072 \\
(0.0036)\end{array}$ & $\begin{array}{c}0.00356^{* *} \\
(0.0016)\end{array}$ & $\begin{array}{l}0.0027 \\
(0.0021)\end{array}$ & $\begin{array}{r}0.00041 \\
(0.0024)\end{array}$ \\
\hline Federal Transfers (\%) & $\begin{array}{l}-0.0284 \\
(0.0231)\end{array}$ & $\begin{array}{l}-0.0114 \\
(0.0286)\end{array}$ & $\begin{array}{c}-0.0192 \\
(0.0299)\end{array}$ & $\begin{array}{l}-0.0165 \\
(0.0307)\end{array}$ & $\begin{array}{l}-0.0194 \\
(0.0372)\end{array}$ & $\begin{array}{l}-0.0288 \\
(0.0404)\end{array}$ & $\begin{array}{r}-0.0116 \\
(0.0379)\end{array}$ & $\begin{array}{l}0.0263 \\
(0.0458)\end{array}$ & $\begin{array}{c}0.00443 \\
(0.0501)\end{array}$ & $\begin{array}{l}0.0596 \\
(0.0549)\end{array}$ \\
\hline States Transfers (\%) & $\begin{array}{l}0.00317 \\
(0.0138)\end{array}$ & $\begin{array}{c}-0.00758 \\
(0.0323)\end{array}$ & $\begin{array}{c}0.000922 \\
(0.0279)\end{array}$ & $\begin{array}{c}-0.00248 \\
(0.0291)\end{array}$ & $\begin{array}{c}-0.0388 \\
(0.0510)\end{array}$ & $\begin{array}{c}-0.0122 \\
(0.0570)\end{array}$ & $\begin{array}{l}-0.0115 \\
(0.0456)\end{array}$ & $\begin{array}{c}-0.0474 \\
(0.0640)\end{array}$ & $\begin{array}{c}-0.0228 \\
(0.0818)\end{array}$ & $\begin{array}{r}-0.0431 \\
(0.0691)\end{array}$ \\
\hline Other Transfers (\%) & $\begin{array}{c}0.0227^{*} \\
(0.0116)\end{array}$ & $\begin{array}{c}0.00911 \\
(0.0296)\end{array}$ & $\begin{array}{c}0.00795 \\
(0.0295)\end{array}$ & $\begin{array}{l}0.0102 \\
(0.0292)\end{array}$ & $\begin{array}{l}0.0501^{*} \\
(0.0258)\end{array}$ & $\begin{array}{c}0.029 \\
(0.0256)\end{array}$ & $\begin{array}{l}0.0373 \\
(0.0325)\end{array}$ & $\begin{array}{l}0.0306 \\
(0.0390)\end{array}$ & $\begin{array}{l}0.0186 \\
(0.0431)\end{array}$ & $\begin{array}{l}0.0193 \\
(0.0651)\end{array}$ \\
\hline Capital Revenues (\%) & $\begin{array}{c}-0.00401 \\
(0.0124)\end{array}$ & $\begin{array}{l}0.0104 \\
(0.0174)\end{array}$ & $\begin{array}{c}0.012 \\
(0.0132)\end{array}$ & $\begin{array}{c}0.012 \\
(0.0135)\end{array}$ & $\begin{array}{l}0.0151 \\
(0.0355)\end{array}$ & $\begin{array}{l}0.0248 \\
(0.0359)\end{array}$ & $\begin{array}{c}0.00936 \\
(0.0379)\end{array}$ & $\begin{array}{c}0.00171 \\
(0.0444)\end{array}$ & $\begin{array}{l}0.0131 \\
(0.0393)\end{array}$ & $\begin{array}{l}-0.0238 \\
(0.0431)\end{array}$ \\
\hline $\begin{array}{l}\text { Observations } \\
\text { Controls }\end{array}$ & 4877 & 2193 & 2193 & 2193 & 249 & 249 & 249 & 161 & 161 & 161 \\
\hline State & Yes & No & Yes & Yes & No & Yes & Yes & No & Yes & No \\
\hline Mayor Party & Yes & No & No & Yes & No & No & Yes & No & No & Yes \\
\hline
\end{tabular}

Using average years of schooling, percentage of poor people, longevity HDI, inequality (Theil Index), children mortality, house infrastructure (telephone and electricity), percentage of woman, mayor party,mayor vote share on the last election, number of electors (as deviation from the threshold), state/municipality fixed effects,electors age composition (young and elderly), political engagement as controls 
Table 38: Electronic voting impact on municpality resource allocation (99 vs 97 - FINBRA)

\begin{tabular}{|c|c|c|c|c|c|c|c|c|c|c|}
\hline Regressions & Full Sample & \multicolumn{2}{|c|}{ Full Sample } & & \multicolumn{2}{|c|}{ Threshold $\pm 20 \mathrm{k}$} & $\begin{array}{l}\text { ization } \\
0 \mathrm{k}\end{array}$ & \multicolumn{2}{|c|}{ Threshold $\pm 15 \mathrm{k}$} & \\
\hline Health (\%) & $\begin{array}{c}0.0281 \\
(0.0171)\end{array}$ & $\begin{array}{c}0.0565^{* *} \\
(0.0236)\end{array}$ & $\begin{array}{c}0.0505^{* *} \\
(0.0184)\end{array}$ & $\begin{array}{c}0.0373^{* *} \\
(0.0156)\end{array}$ & $\begin{array}{c}0.105^{* *} \\
(0.0373)\end{array}$ & $\begin{array}{c}0.0955^{* *} \\
(0.0442)\end{array}$ & $\begin{array}{c}0.102^{*} \\
(0.0581)\end{array}$ & $\begin{array}{c}0.128^{* * *} \\
(0.0357)\end{array}$ & $\begin{array}{c}0.125^{* * *} \\
(0.0360)\end{array}$ & $\begin{array}{c}0.131^{* *} \\
(0.0474)\end{array}$ \\
\hline Education (\%) & $\begin{array}{c}-0.0237^{*} \\
(0.0114)\end{array}$ & $\begin{array}{c}-0.0516^{* *} \\
(0.0241)\end{array}$ & $\begin{array}{c}-0.0436^{*} \\
(0.0216)\end{array}$ & $\begin{array}{c}-0.0418^{*} \\
(0.0229)\end{array}$ & $\begin{array}{c}-0.0609 \\
(0.0470)\end{array}$ & $\begin{array}{c}-0.0373 \\
(0.0469)\end{array}$ & $\begin{array}{c}-0.0379 \\
(0.0580)\end{array}$ & $\begin{array}{c}-0.1 \\
(0.0570)\end{array}$ & $\begin{array}{c}-0.0794 \\
(0.0574)\end{array}$ & $\begin{array}{c}-0.113 \\
(0.0656)\end{array}$ \\
\hline Housing (\%) & $\begin{array}{c}-0.0199 \\
(0.0153)\end{array}$ & $\begin{array}{c}-0.00571 \\
(0.0205)\end{array}$ & $\begin{array}{c}-0.0069 \\
(0.0220)\end{array}$ & $\begin{array}{c}-0.00239 \\
(0.0210)\end{array}$ & $\begin{array}{c}0.0491 \\
(0.0336)\end{array}$ & $\begin{array}{c}0.0162 \\
(0.0397)\end{array}$ & $\begin{array}{c}-0.00703 \\
(0.0472)\end{array}$ & $\begin{array}{l}0.0237 \\
(0.0484)\end{array}$ & $\begin{array}{c}-0.0145 \\
(0.0601)\end{array}$ & $\begin{array}{c}-0.00319 \\
(0.0441)\end{array}$ \\
\hline Administration (\%) & $\begin{array}{c}0.0104 \\
(0.0230)\end{array}$ & $\begin{array}{c}-0.00347 \\
(0.0286)\end{array}$ & $\begin{array}{c}0.000831 \\
(0.0291)\end{array}$ & $\begin{array}{c}0.00876 \\
(0.0284)\end{array}$ & $\begin{array}{c}-0.0708^{*} \\
(0.0339)\end{array}$ & $\begin{array}{c}-0.0707 \\
(0.0410)\end{array}$ & $\begin{array}{c}-0.0471 \\
(0.0481)\end{array}$ & $\begin{array}{c}-0.0307 \\
(0.0549)\end{array}$ & $\begin{array}{c}-0.0401 \\
(0.0670)\end{array}$ & $\begin{array}{c}0.00784 \\
(0.0687)\end{array}$ \\
\hline Public Security (\%) & $\begin{array}{c}0.000885 \\
(0.0017)\end{array}$ & $\begin{array}{c}0.00072 \\
(0.0027)\end{array}$ & $\begin{array}{c}0.000666 \\
(0.0029)\end{array}$ & $\begin{array}{c}0.0012 \\
(0.0032)\end{array}$ & $\begin{array}{c}-0.000701 \\
(0.0018)\end{array}$ & $\begin{array}{c}-0.000744 \\
(0.0020)\end{array}$ & $\begin{array}{c}0.00131 \\
(0.0009)\end{array}$ & $\begin{array}{c}-0.00157 \\
(0.0023)\end{array}$ & $\begin{array}{c}-0.0012 \\
(0.0026)\end{array}$ & $\begin{array}{c}0.0041 \\
(0.0028)\end{array}$ \\
\hline Development (\%) & $\begin{array}{c}-0.0044 \\
(0.0114)\end{array}$ & $\begin{array}{c}-0.00134 \\
(0.0141)\end{array}$ & $\begin{array}{c}-0.00505 \\
(0.0157)\end{array}$ & $\begin{array}{c}-0.00937 \\
(0.0151)\end{array}$ & $\begin{array}{c}-0.0013 \\
(0.0321)\end{array}$ & $\begin{array}{c}0.00127 \\
(0.0364)\end{array}$ & $\begin{array}{c}0.00182 \\
(0.0319)\end{array}$ & $\begin{array}{c}0.00823 \\
(0.0371)\end{array}$ & $\begin{array}{c}0.0174 \\
(0.0394)\end{array}$ & $\begin{array}{c}0.0132 \\
(0.0374)\end{array}$ \\
\hline Others $(\%)$ & $\begin{array}{c}0.00864 \\
(0.0067)\end{array}$ & $\begin{array}{c}0.00482 \\
(0.0126)\end{array}$ & $\begin{array}{c}0.00362 \\
(0.0123)\end{array}$ & $\begin{array}{c}0.00633 \\
(0.0113)\end{array}$ & $\begin{array}{c}-0.0203 \\
(0.0256)\end{array}$ & $\begin{array}{c}-0.00417 \\
(0.0228)\end{array}$ & $\begin{array}{l}-0.013 \\
(0.0192)\end{array}$ & $\begin{array}{c}-0.0277 \\
(0.0323)\end{array}$ & $\begin{array}{c}-0.00741 \\
(0.0291)\end{array}$ & $\begin{array}{c}-0.0397 \\
(0.0284)\end{array}$ \\
\hline $\begin{array}{l}\text { Observations } \\
\text { Controls }\end{array}$ & 3869 & 1757 & 1757 & 1757 & 202 & 202 & 202 & 130 & 130 & 130 \\
\hline $\begin{array}{l}\text { State } \\
\text { Mayor Party }\end{array}$ & $\begin{array}{l}\text { Yes } \\
\text { Yes }\end{array}$ & - & $\begin{array}{c}\text { Yes } \\
-\end{array}$ & $\begin{array}{l}\text { Yes } \\
\text { Yes }\end{array}$ & - & $\begin{array}{c}\text { Yes } \\
-\end{array}$ & $\begin{array}{l}\text { Yes } \\
\text { Yes }\end{array}$ & - & $\begin{array}{c}\text { Yes } \\
-\end{array}$ & $\begin{array}{c}- \\
\text { Yes }\end{array}$ \\
\hline
\end{tabular}

Robust standard errors in parentheses

$* * * \mathrm{p}<0.01, * * \mathrm{p}<0.05, * \mathrm{p}<0.1$

Using percentage of woman, mayor vote share on the last election, number of electors,

mayor party, state fixed effects, proportion of rural population, wealth and longevity HDI

percentage of woman, mayor vote share on the last election, number of electors, as controls

Using average years of schooling, percentage of poor people, longevity HDI, inequality (Theil Index), children mortality, house infrastructure (telephone and electricity), percentage of woman, mayor party, mayor vote share on the last election, number of electors (as deviation from the threshold), state/municipality fixed effects, electors age composition (young and elderly), political engagement as controls

Table 39: Electronic voting impact on municpality resource allocation (99 vs 97 - FINBRA)

\begin{tabular}{|c|c|c|c|c|c|c|c|c|c|c|}
\hline \multirow{2}{*}{$\begin{array}{l}\text { Regressions } \\
\text { Health }(\%)\end{array}$} & Full Sample & \multicolumn{3}{|c|}{ Full Sample } & \multicolumn{3}{|c|}{ Threshold $\pm 20 \mathrm{k}$} & \multicolumn{3}{|c|}{ Threshold $\pm 15 \mathrm{k}$} \\
\hline & $\begin{array}{l}0.0281 \\
(0.0171)\end{array}$ & $\begin{array}{c}0.0344 \\
(0.0449)\end{array}$ & $\begin{array}{c}0.0251 \\
(0.0451)\end{array}$ & $\begin{array}{c}0.0224 \\
(0.0445)\end{array}$ & $\begin{array}{c}-0.0417 \\
(0.0473)\end{array}$ & $\begin{array}{c}-0.0753 \\
(0.0609)\end{array}$ & $\begin{array}{c}-0.0948 \\
(0.0585)\end{array}$ & $\begin{array}{c}-0.0572 \\
(0.0625)\end{array}$ & $\begin{array}{l}-0.103 \\
(0.0773)\end{array}$ & $\begin{array}{l}-0.057 \\
(0.0750)\end{array}$ \\
\hline Education (\%) & $\begin{array}{c}-0.0237^{*} \\
(0.0114)\end{array}$ & $\begin{array}{c}0.00195 \\
(0.0177)\end{array}$ & $\begin{array}{c}-0.00474 \\
(0.0189)\end{array}$ & $\begin{array}{c}-0.00532 \\
(0.0184)\end{array}$ & $\begin{array}{c}-0.00699 \\
(0.0429)\end{array}$ & $\begin{array}{c}0.0169 \\
(0.0342)\end{array}$ & $\begin{array}{c}0.0172 \\
(0.0330)\end{array}$ & $\begin{array}{c}-0.0053 \\
(0.0568)\end{array}$ & $\begin{array}{c}0.0335 \\
(0.0439)\end{array}$ & $\begin{array}{c}-0.0158 \\
(0.0494)\end{array}$ \\
\hline Housing (\%) & $\begin{array}{c}-0.0199 \\
(0.0153)\end{array}$ & $\begin{array}{c}-0.0415^{* *} \\
(0.0166)\end{array}$ & $\begin{array}{c}-0.0377^{* *} \\
(0.0150)\end{array}$ & $\begin{array}{c}-0.0390 * * \\
(0.0149)\end{array}$ & $\begin{array}{c}-0.0627 \\
(0.0393)\end{array}$ & $\begin{array}{c}-0.0458 \\
(0.0472)\end{array}$ & $\begin{array}{c}-0.0385 \\
(0.0414)\end{array}$ & $\begin{array}{c}-0.0458 \\
(0.0476)\end{array}$ & $\begin{array}{c}-0.0496 \\
(0.0621)\end{array}$ & $\begin{array}{c}-0.0269 \\
(0.0544)\end{array}$ \\
\hline Administration (\%) & $\begin{array}{c}0.0104 \\
(0.0230)\end{array}$ & $\begin{array}{l}0.015 \\
(0.0367)\end{array}$ & $\begin{array}{c}0.0254 \\
(0.0346)\end{array}$ & $\begin{array}{l}0.032 \\
(0.0352)\end{array}$ & $\begin{array}{c}0.0880^{* * *} \\
(0.0304)\end{array}$ & $\begin{array}{l}0.087 \\
(0.0512)\end{array}$ & $\begin{array}{c}0.117^{*} \\
(0.0590)\end{array}$ & $\begin{array}{c}0.0966^{* *} \\
(0.0373)\end{array}$ & $\begin{array}{c}0.0862 \\
(0.0542)\end{array}$ & $\begin{array}{l}0.0925 \\
(0.0544)\end{array}$ \\
\hline Public Security (\%) & $\begin{array}{c}0.000885 \\
(0.0017)\end{array}$ & $\begin{array}{c}0.000812 \\
(0.0011)\end{array}$ & $\begin{array}{c}0.00123 \\
(0.0010)\end{array}$ & $\begin{array}{c}0.000668 \\
(0.0010)\end{array}$ & $\begin{array}{c}-0.00253 \\
(0.0019)\end{array}$ & $\begin{array}{c}-0.00122 \\
(0.0016)\end{array}$ & $\begin{array}{c}-0.00159 \\
(0.0017)\end{array}$ & $\begin{array}{c}-0.000501 \\
(0.0022)\end{array}$ & $\begin{array}{c}0.000619 \\
(0.0020)\end{array}$ & $\begin{array}{c}0.000166 \\
(0.0022)\end{array}$ \\
\hline Development (\%) & $\begin{array}{c}-0.0044 \\
(0.0114)\end{array}$ & $\begin{array}{c}-0.0171 \\
(0.0156)\end{array}$ & $\begin{array}{c}-0.0144 \\
(0.0174)\end{array}$ & $\begin{array}{c}-0.0185 \\
(0.0176)\end{array}$ & $\begin{array}{c}0.0222 \\
(0.0297)\end{array}$ & $\begin{array}{l}0.032 \\
(0.0264)\end{array}$ & $\begin{array}{c}0.0284 \\
(0.0284)\end{array}$ & $\begin{array}{c}0.0171 \\
(0.0318)\end{array}$ & $\begin{array}{c}0.0489 \\
(0.0451)\end{array}$ & $\begin{array}{c}0.0115 \\
(0.0396)\end{array}$ \\
\hline Others (\%) & $\begin{array}{c}0.00864 \\
(0.0067)\end{array}$ & $\begin{array}{c}0.0064 \\
(0.0115)\end{array}$ & $\begin{array}{c}0.00503 \\
(0.0112)\end{array}$ & $\begin{array}{c}0.00773 \\
(0.0109)\end{array}$ & $\begin{array}{c}0.00366 \\
(0.0269)\end{array}$ & $\begin{array}{c}-0.0136 \\
(0.0270)\end{array}$ & $\begin{array}{c}-0.0277 \\
(0.0303)\end{array}$ & $\begin{array}{c}-0.00485 \\
(0.0226)\end{array}$ & $\begin{array}{c}-0.0169 \\
(0.0252)\end{array}$ & $\begin{array}{c}-0.00439 \\
(0.0284)\end{array}$ \\
\hline $\begin{array}{l}\text { Observations } \\
\text { Controls }\end{array}$ & 3869 & 2112 & 2112 & 2112 & 216 & 216 & 216 & 135 & 135 & 135 \\
\hline $\begin{array}{l}\text { State } \\
\text { Mavor Party }\end{array}$ & $\begin{array}{l}\text { Yes } \\
\text { Yes }\end{array}$ & - & Yes & Yes & - & Yes & Yes & - & Yes & - \\
\hline & & - & $\begin{array}{l}\text { Robust } \\
* * * \mathrm{p}\end{array}$ & lard er & $\begin{array}{l}\text { in pare } \\
05, * \mathrm{p}\end{array}$ & & & - & - & res \\
\hline
\end{tabular}

Using average years of schooling, percentage of poor people, longevity HDI, inequality (Theil Index), children mortality, house infrastructure (telephone and electricity), percentage of woman, mayor party, mayor vote share on the last election, number of electors (as deviation from the threshold), state/municipality fixed effects,electors age composition (young and elderly), political engagement as controls 
Table 40: Electronic voting impact on municpality resource allocation (99 vs 97 - FINBRA)

\begin{tabular}{|c|c|c|c|c|c|c|c|c|c|c|}
\hline \multirow{2}{*}{ Regressions } & \multirow[t]{2}{*}{ Full Sample } & \multicolumn{9}{|c|}{ Bottom Fractionalization } \\
\hline & & \multicolumn{3}{|c|}{ Full Sample } & \multicolumn{3}{|c|}{ Threshold $\pm 20 \mathrm{k}$} & \multicolumn{3}{|c|}{ Threshold $\pm 15 \mathrm{k}$} \\
\hline Tax Revenues (\%) & $\begin{array}{c}-0.0902 \\
(0.0748)\end{array}$ & $\begin{array}{l}-0.106 \\
(0.0819)\end{array}$ & $\begin{array}{l}-0.105 \\
(0.0790)\end{array}$ & $\begin{array}{c}-0.0943 \\
(0.0782)\end{array}$ & $\begin{array}{c}-0.203 \\
(0.1530)\end{array}$ & $\begin{array}{l}-0.137 \\
(0.1390)\end{array}$ & $\begin{array}{c}-0.167 \\
(0.1540)\end{array}$ & $\begin{array}{c}-0.202 \\
(0.1440)\end{array}$ & $\begin{array}{c}-0.183 \\
(0.1160)\end{array}$ & $\begin{array}{c}-0.204 \\
(0.1860)\end{array}$ \\
\hline Federal Transfers (\%) & $\begin{array}{c}-0.0246 \\
(0.0149)\end{array}$ & $\begin{array}{c}0.00714 \\
(0.0327)\end{array}$ & $\begin{array}{c}0.0142 \\
(0.0372)\end{array}$ & $\begin{array}{c}0.0149 \\
(0.0367)\end{array}$ & $\begin{array}{c}-0.0225 \\
(0.0552)\end{array}$ & $\begin{array}{c}-0.045 \\
(0.0591)\end{array}$ & $\begin{array}{c}-0.0683 \\
(0.0615)\end{array}$ & $\begin{array}{c}-0.0581 \\
(0.0558)\end{array}$ & $\begin{array}{c}-0.0829 \\
(0.0583)\end{array}$ & $\begin{array}{c}-0.0573 \\
(0.0639)\end{array}$ \\
\hline State Transfers (\%) & $\begin{array}{c}0.0398 \\
(0.0330)\end{array}$ & $\begin{array}{c}0.0302 \\
(0.0230)\end{array}$ & $\begin{array}{c}0.00888 \\
(0.0167)\end{array}$ & $\begin{array}{c}0.00544 \\
(0.0155)\end{array}$ & $\begin{array}{l}0.0136 \\
(0.0606)\end{array}$ & $\begin{array}{c}-0.0155 \\
(0.0549)\end{array}$ & $\begin{array}{c}-0.0156 \\
(0.0698)\end{array}$ & $\begin{array}{c}-0.0246 \\
(0.0386)\end{array}$ & $\begin{array}{c}-0.0539 \\
(0.0459)\end{array}$ & $\begin{array}{c}-0.0465 \\
(0.0609)\end{array}$ \\
\hline Capital Revenues (\%) & $\begin{array}{c}0.0750^{*} \\
(0.0436)\end{array}$ & $\begin{array}{c}0.0686 \\
(0.0570)\end{array}$ & $\begin{array}{c}0.0818 \\
(0.0485)\end{array}$ & $\begin{array}{l}0.074 \\
(0.0516)\end{array}$ & $\begin{array}{l}0.212 \\
(0.1270)\end{array}$ & $\begin{array}{c}0.198^{*} \\
(0.1020)\end{array}$ & $\begin{array}{c}0.251^{* *} \\
(0.0956)\end{array}$ & $\begin{array}{c}0.284^{* *} \\
(0.1310)\end{array}$ & $\begin{array}{c}0.320 * * * \\
(0.1000)\end{array}$ & $\begin{array}{l}0.308^{*} \\
(0.1530)\end{array}$ \\
\hline $\begin{array}{l}\text { Observations } \\
\text { Controls }\end{array}$ & 3913 & 1775 & 1775 & 1775 & 207 & 207 & 207 & 133 & 133 & 133 \\
\hline State & Yes & - & Yes & Yes & - & Yes & Yes & - & Yes & - \\
\hline Mayor Party & Yes & - & - & Yes & - & - & Yes & - & - & Yes \\
\hline
\end{tabular}

Using average years of schooling, percentage of poor people, longevity HDI, inequality (Theil Index), children mortality, house infrastructure (telephone and electricity), percentage of woman, mayor party, mayor vote share on the last election, number of electors (as deviation from the threshold), state/municipality fixed effects,electors age composition (young and elderly), political

engagement as controls 


\section{Robustness Tests}

\section{D.1 Results with municipalities with number of electors around the threshold $(20,500-60,500)$}

Table 41: Discontinuity - Electronic voting impact on Invalid Votes

\begin{tabular}{|c|c|c|c|c|c|c|c|c|}
\hline Dep. Var.: Invalid & Pres & dent & Gove & rnor & Federal & Deputy & State I & Deputy \\
\hline Regressions & $\overline{(1)}$ & $\overline{(2)}$ & (1) & (2) & (1) & (2) & (1) & (2) \\
\hline Electronic Voting (EV) & $\begin{array}{c}-0.000126 \\
(0.0048)\end{array}$ & & $\begin{array}{c}-0.00594 \\
(0.0084)\end{array}$ & & $\begin{array}{l}-0.015 \\
(0.0152)\end{array}$ & & $\begin{array}{c}0.00413 \\
(0.0157)\end{array}$ & \\
\hline Year $=1998$ & $\begin{array}{c}-0.00264 \\
(0.0017)\end{array}$ & $\begin{array}{c}-0.00154 \\
(0.0022)\end{array}$ & $\begin{array}{c}-0.0302^{* * *} \\
(0.0036)\end{array}$ & $\begin{array}{c}-0.0324^{* * *} \\
(0.0051)\end{array}$ & $\begin{array}{c}-0.104^{* * *} \\
(0.0046)\end{array}$ & $\begin{array}{c}-0.107^{* * *} \\
(0.0061)\end{array}$ & $\begin{array}{c}-0.0775 * * * \\
(0.0047)\end{array}$ & $\begin{array}{c}-0.0798^{* * *} \\
(0.0059)\end{array}$ \\
\hline $\mathrm{EV} *$ Year $=1998[\mathrm{EV}(98)]$ & $\begin{array}{c}-0.0265^{* * *} \\
(0.0047)\end{array}$ & $\begin{array}{c}-0.0271^{* * *} \\
(0.0043)\end{array}$ & $\begin{array}{c}-0.0831^{* * *} \\
(0.0092)\end{array}$ & $\begin{array}{c}-0.0906^{* * *} \\
(0.0090)\end{array}$ & $\begin{array}{c}-0.207 * * * \\
(0.0123)\end{array}$ & $\begin{array}{c}-0.220^{* * *} \\
(0.0126)\end{array}$ & $\begin{array}{c}-0.126^{* * *} \\
(0.0118)\end{array}$ & $\begin{array}{c}-0.142^{* * * *} \\
(0.0120)\end{array}$ \\
\hline Poor People (\%) & $\begin{array}{c}0.0254^{* * *} \\
(0.0052)\end{array}$ & & $\begin{array}{c}0.0199 * * \\
(0.0080)\end{array}$ & & $\begin{array}{c}0.0265^{* *} \\
(0.0132)\end{array}$ & & $\begin{array}{c}0.0271^{*} \\
(0.0143)\end{array}$ & \\
\hline EV $(98) *$ Poor People $(\%)$ & $\begin{array}{c}-0.00418 \\
(0.0081)\end{array}$ & $\begin{array}{c}-0.00936 \\
(0.0077)\end{array}$ & $\begin{array}{l}0.014 \\
(0.0154)\end{array}$ & $\begin{array}{c}0.0142 \\
(0.0153)\end{array}$ & $\begin{array}{c}-0.0456^{* *} \\
(0.0231)\end{array}$ & $\begin{array}{c}-0.0317 \\
(0.0233)\end{array}$ & $\begin{array}{c}0.0115 \\
(0.0224)\end{array}$ & $\begin{array}{c}0.0189 \\
(0.0224)\end{array}$ \\
\hline $\mathrm{EV}^{*}$ Poor People $(\%)$ & $\begin{array}{c}-0.0165^{* *} \\
(0.0070)\end{array}$ & & $\begin{array}{c}-0.0186 \\
(0.0127)\end{array}$ & & $\begin{array}{l}0.0329 \\
(0.0224)\end{array}$ & & $\begin{array}{c}-0.00517 \\
(0.0226)\end{array}$ & \\
\hline Year $=1998^{*}$ Poor People $(\%)$ & $\begin{array}{c}-0.0109^{* * *} \\
(0.0040)\end{array}$ & $\begin{array}{c}-0.00900^{* *} \\
(0.0037)\end{array}$ & $\begin{array}{c}-0.00772 \\
(0.0080)\end{array}$ & $\begin{array}{c}-0.00387 \\
(0.0077)\end{array}$ & $\begin{array}{c}-0.0192^{*} \\
(0.0109)\end{array}$ & $\begin{array}{c}-0.0161 \\
(0.0107)\end{array}$ & $\begin{array}{c}-0.0185^{*} \\
(0.0107)\end{array}$ & $\begin{array}{c}-0.0133 \\
(0.0100)\end{array}$ \\
\hline Years of study & $\begin{array}{c}-0.0131^{* * *} \\
(0.0048)\end{array}$ & & $\begin{array}{c}-0.0112 \\
(0.0074)\end{array}$ & & $\begin{array}{l}0.0027 \\
(0.0128)\end{array}$ & & $\begin{array}{c}0.00522 \\
(0.0122)\end{array}$ & \\
\hline EV $(98)^{*}$ Years of study & $\begin{array}{c}0.0221^{* * *} \\
(0.0081)\end{array}$ & $\begin{array}{c}0.0177^{* *} \\
(0.0078)\end{array}$ & $\begin{array}{c}0.0414^{* * * *} \\
(0.0159)\end{array}$ & $\begin{array}{c}0.0438 * * * \\
(0.0160)\end{array}$ & $\begin{array}{c}-0.00534 \\
(0.0216)\end{array}$ & $\begin{array}{c}0.00369 \\
(0.0216)\end{array}$ & $\begin{array}{c}-0.00312 \\
(0.0200)\end{array}$ & $\begin{array}{c}0.00837 \\
(0.0199)\end{array}$ \\
\hline EV*Years of study & $\begin{array}{c}-0.0158^{* *} \\
(0.0073)\end{array}$ & & $\begin{array}{c}-0.0183 \\
(0.0122)\end{array}$ & & $\begin{array}{l}0.0168 \\
(0.0205)\end{array}$ & & $\begin{array}{l}0.0111 \\
(0.0199)\end{array}$ & \\
\hline Year $=1998^{*}$ Years of study & $\begin{array}{c}-0.0142^{* * *} \\
(0.0044)\end{array}$ & $\begin{array}{c}-0.0117^{* * *} \\
(0.0043)\end{array}$ & $\begin{array}{c}-0.0339 * * * \\
(0.0090)\end{array}$ & $\begin{array}{c}-0.0315^{* * *} \\
(0.0089)\end{array}$ & $\begin{array}{c}-0.0179 * \\
(0.0105)\end{array}$ & $\begin{array}{c}-0.0103 \\
(0.0102)\end{array}$ & $\begin{array}{c}-0.00983 \\
(0.0104)\end{array}$ & $\begin{array}{c}-0.00864 \\
(0.0097)\end{array}$ \\
\hline Constant & $\begin{array}{c}0.161^{* * *} \\
(0.0089)\end{array}$ & $\begin{array}{c}0.215^{* * * *} \\
(0.0066)\end{array}$ & $\begin{array}{c}0.224^{* * *} \\
(0.0149)\end{array}$ & $\begin{array}{c}0.329^{* * *} * \\
(0.0153)\end{array}$ & $\begin{array}{c}0.357^{* * *} * \\
(0.0292)\end{array}$ & $\begin{array}{c}0.431^{* * *} \\
(0.0202)\end{array}$ & $\begin{array}{c}0.216^{* * *} \\
(0.0250)\end{array}$ & $\begin{array}{c}0.347^{* * *} \\
(0.0176)\end{array}$ \\
\hline Observations & 1074 & $\begin{array}{c}1074 \\
\text { Robust } \\
* * * \\
\text { (1) Poole }\end{array}$ & $\begin{array}{c}1074 \\
\text { dard erro } \\
1, * * \mathrm{p} \\
\text { gression }\end{array}$ & $\begin{array}{c}1074 \\
\text { parent } \\
* \mathrm{p}<0 \\
\text { Fixed } \mathrm{E}\end{array}$ & 1074 & 1074 & 1074 & 1074 \\
\hline
\end{tabular}

Using average years of schooling, percentage of poor people, longevity HDI, inequality (Theil Index), children mortality, house infrastructure (telephone and electricity), percentage of woman, mayor party, mayor vote share on the last election, number of electors (as deviation from the threshold), state/municipality fixed effects,electors age composition (young and elderly), political engagement as controls 
Table 42: Discontinuity - Electronic voting impact on Blank Votes

\begin{tabular}{|c|c|c|c|c|c|c|c|c|}
\hline Dep. Var.: Blank & \multicolumn{2}{|c|}{ President } & \multicolumn{2}{|c|}{ Governor } & \multicolumn{2}{|c|}{ Federal Deputy } & \multicolumn{2}{|c|}{ State Deputy } \\
\hline Regressions & (1) & (2) & (1) & (2) & (1) & (2) & (1) & 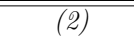 \\
\hline Electronic Voting (EV) & $\begin{array}{c}-0.000569 \\
(0.0034)\end{array}$ & & $\begin{array}{c}-0.00491 \\
(0.0072)\end{array}$ & & $\begin{array}{c}-0.0151^{* *} \\
(0.0077)\end{array}$ & & $\begin{array}{c}0.00128 \\
(0.0075)\end{array}$ & \\
\hline Year $=1998$ & $\begin{array}{c}0.00331 * * \\
(0.0016)\end{array}$ & $\begin{array}{c}0.000241 \\
(0.0021)\end{array}$ & $\begin{array}{c}-0.0174^{* * *} \\
(0.0034)\end{array}$ & $\begin{array}{c}-0.0206^{* * *} \\
(0.0045)\end{array}$ & $\begin{array}{c}-0.0503^{* * *} \\
(0.0029)\end{array}$ & $\begin{array}{c}-0.0519^{* * *} \\
(0.0037)\end{array}$ & $\begin{array}{c}-0.0489^{* * *} \\
(0.0023)\end{array}$ & $\begin{array}{c}-0.0507^{* * *} \\
(0.0031)\end{array}$ \\
\hline EV * Year $=1998[\mathrm{EV}(98)]$ & $\begin{array}{c}-0.0722^{* * *} \\
(0.0038)\end{array}$ & $\begin{array}{c}-0.0723^{* * *} \\
(0.0037)\end{array}$ & $\begin{array}{c}-0.145^{* * *} \\
(0.0094)\end{array}$ & $\begin{array}{c}-0.144^{* * *} \\
(0.0090)\end{array}$ & $\begin{array}{c}-0.0749^{* * *} \\
(0.0071)\end{array}$ & $\begin{array}{c}-0.0775^{* * *} \\
(0.0066)\end{array}$ & $\begin{array}{c}-0.0359^{* * *} \\
(0.0062)\end{array}$ & $\begin{array}{c}-0.0400^{* * *} \\
(0.0061)\end{array}$ \\
\hline Poor People (\%) & $\begin{array}{c}0.0263^{* * *} \\
(0.0040)\end{array}$ & & $\begin{array}{c}0.0232^{* * *} \\
(0.0068)\end{array}$ & & $\begin{array}{c}0.0311^{* * *} \\
(0.0072)\end{array}$ & & $\begin{array}{c}0.0281^{* * *} \\
(0.0068)\end{array}$ & \\
\hline EV $(98)^{*}$ Poor People (\%) & $\begin{array}{c}-0.0106 \\
(0.0068)\end{array}$ & $\begin{array}{c}-0.0164^{* * *} \\
(0.0063)\end{array}$ & $\begin{array}{c}-0.0202 \\
(0.0149)\end{array}$ & $\begin{array}{c}-0.0223 \\
(0.0153)\end{array}$ & $\begin{array}{c}-0.0574^{* * *} \\
(0.0138)\end{array}$ & $\begin{array}{c}-0.0537^{* * *} \\
(0.0139)\end{array}$ & $\begin{array}{c}-0.0180^{*} \\
(0.0097)\end{array}$ & $\begin{array}{c}-0.0171^{*} \\
(0.0101)\end{array}$ \\
\hline EV*Poor People (\%) & $\begin{array}{c}-0.00373 \\
(0.0052)\end{array}$ & & $\begin{array}{l}-0.011 \\
(0.0106)\end{array}$ & & $\begin{array}{c}0.0191 \\
(0.0127)\end{array}$ & & $\begin{array}{c}-0.0042 \\
(0.0095)\end{array}$ & \\
\hline Year $=1998^{*}$ Poor People $(\%)$ & $\begin{array}{c}-0.0129 * * * \\
(0.0037)\end{array}$ & $\begin{array}{c}-0.00999 * * * \\
(0.0036)\end{array}$ & $\begin{array}{c}-0.0121 \\
(0.0078)\end{array}$ & $\begin{array}{c}-0.00875 \\
(0.0075)\end{array}$ & $\begin{array}{c}-0.0206^{* * *} \\
(0.0066)\end{array}$ & $\begin{array}{c}-0.0187^{* * *} \\
(0.0065)\end{array}$ & $\begin{array}{c}-0.0186^{* * *} \\
(0.0052)\end{array}$ & $\begin{array}{c}-0.0156^{* * *} \\
(0.0050)\end{array}$ \\
\hline Years of study & $\begin{array}{c}-0.0142^{* * *} \\
(0.0039)\end{array}$ & & $\begin{array}{c}-0.0166^{* *} \\
(0.0067)\end{array}$ & & $\begin{array}{c}-0.00611 \\
(0.0069)\end{array}$ & & $\begin{array}{c}-0.00708 \\
(0.0059)\end{array}$ & \\
\hline EV(98)*Years of study & $\begin{array}{c}0.0297^{* * *} \\
(0.0066)\end{array}$ & $\begin{array}{c}0.0277^{* * *} \\
(0.0067)\end{array}$ & $\begin{array}{c}0.0528^{* * *} \\
(0.0146)\end{array}$ & $\begin{array}{c}0.0530 * * * \\
(0.0146)\end{array}$ & $\begin{array}{c}-0.00817 \\
(0.0129)\end{array}$ & $\begin{array}{c}-0.00407 \\
(0.0132)\end{array}$ & $\begin{array}{c}-0.000136 \\
(0.0098)\end{array}$ & $\begin{array}{c}0.00613 \\
(0.0102)\end{array}$ \\
\hline $\mathrm{EV}^{*}$ Years of study & $\begin{array}{c}-0.00479 \\
(0.0055)\end{array}$ & & $\begin{array}{c}-0.0114 \\
(0.0103)\end{array}$ & & $\begin{array}{c}0.00916 \\
(0.0125)\end{array}$ & & $\begin{array}{c}0.00458 \\
(0.0095)\end{array}$ & \\
\hline Year $=1998^{*}$ Years of study & $\begin{array}{c}-0.00700^{*} \\
(0.0042)\end{array}$ & $\begin{array}{c}-0.00521 \\
(0.0042)\end{array}$ & $\begin{array}{c}-0.0326^{* * *} \\
(0.0089)\end{array}$ & $\begin{array}{c}-0.0310^{* * *} \\
(0.0087)\end{array}$ & $\begin{array}{c}-0.0126^{*} \\
(0.0065)\end{array}$ & $\begin{array}{c}-0.00727 \\
(0.0063)\end{array}$ & $\begin{array}{c}-0.00361 \\
(0.0052)\end{array}$ & $\begin{array}{c}-0.00316 \\
(0.0050)\end{array}$ \\
\hline Constant & $\begin{array}{c}0.0691^{* * *} \\
(0.0068) \\
\end{array}$ & $\begin{array}{c}0.125^{* * * *} \\
(0.0060)\end{array}$ & $\begin{array}{c}0.166^{* * *} \\
(0.0148)\end{array}$ & $\begin{array}{c}0.252^{* * *} \\
(0.0133) \\
\end{array}$ & $\begin{array}{c}0.177^{* * *} \\
(0.0169) \\
\end{array}$ & $\begin{array}{c}0.207^{* * *} \\
(0.0114) \\
\end{array}$ & $\begin{array}{c}0.102^{* * *} \\
(0.0120) \\
\end{array}$ & $\begin{array}{c}0.170 * * * \\
(0.0090) \\
\end{array}$ \\
\hline Observations & 1074 & $\begin{array}{l}1074 \\
\text { Robus } \\
* * *\end{array}$ & $\begin{array}{c}1074 \\
\text { dard er }\end{array}$ & $\begin{array}{l}1074 \\
\text { paren }\end{array}$ & 1074 & 1074 & 1074 & 1074 \\
\hline
\end{tabular}

(1) Pooled regression; (2) Fixed Effects

Using average years of schooling, percentage of poor people, longevity HDI, inequality (Theil Index), children mortality, house infrastructure (telephone and electricity), percentage of woman, mayor party, mayor vote share on the last election, number of electors (as deviation from the threshold), state/municipality fixed effects, electors age composition (young and elderly), political engagement as controls 
Table 43: Discontinuity - Electronic voting impact on Spoiled Votes

\begin{tabular}{|c|c|c|c|c|c|c|c|c|}
\hline Dep. Var.: Spoiled & \multicolumn{2}{|c|}{ President } & \multicolumn{2}{|c|}{ Governor } & \multicolumn{2}{|c|}{ Federal Deputy } & \multicolumn{2}{|c|}{ State Deputy } \\
\hline Regressions & (1) & (2) & (1) & (2) & (1) & (2) & (1) & (2) \\
\hline Electronic Voting (EV) & $\begin{array}{c}0.000444 \\
(0.0033)\end{array}$ & & $\begin{array}{c}-0.00103 \\
(0.0032)\end{array}$ & & $\begin{array}{c}0.0000212 \\
(0.0102)\end{array}$ & & $\begin{array}{c}0.00284 \\
(0.0094)\end{array}$ & \\
\hline Year $=1998$ & $\begin{array}{c}-0.00595^{* * *} \\
(0.0014)\end{array}$ & $\begin{array}{c}-0.00178 \\
(0.0019)\end{array}$ & $\begin{array}{c}-0.0129 * * * \\
(0.0010)\end{array}$ & $\begin{array}{c}-0.0119^{* * *} \\
(0.0020)\end{array}$ & $\begin{array}{c}-0.0541^{* * *} \\
(0.0030)\end{array}$ & $\begin{array}{c}-0.0550 * * * \\
(0.0044)\end{array}$ & $\begin{array}{c}-0.0286^{* * *} \\
(0.0031)\end{array}$ & $\begin{array}{c}-0.0291^{* * *} \\
(0.0038)\end{array}$ \\
\hline $\mathrm{EV} *$ Year $=1998[\mathrm{EV}(98)]$ & $\begin{array}{c}0.0456^{* * *} \\
(0.0038)\end{array}$ & $\begin{array}{c}0.0452^{* * *} \\
(0.0034)\end{array}$ & $\begin{array}{c}0.0614^{* * *} \\
(0.0047)\end{array}$ & $\begin{array}{c}0.0532^{* * *} \\
(0.0041)\end{array}$ & $\begin{array}{c}-0.132^{* * *} \\
(0.0082)\end{array}$ & $\begin{array}{c}-0.143^{* * *} \\
(0.0095)\end{array}$ & $\begin{array}{c}-0.0902^{* * *} \\
(0.0072)\end{array}$ & $\begin{array}{c}-0.102^{* * *} \\
(0.0077)\end{array}$ \\
\hline Poor People (\%) & $\begin{array}{c}-0.000914 \\
(0.0034)\end{array}$ & & $\begin{array}{c}-0.00331 \\
(0.0031)\end{array}$ & & $\begin{array}{c}-0.00461 \\
(0.0092)\end{array}$ & & $\begin{array}{c}-0.000981 \\
(0.0091)\end{array}$ & \\
\hline EV $(98) *$ Poor People (\%) & $\begin{array}{c}0.00638 \\
(0.0072)\end{array}$ & $\begin{array}{c}0.00707 \\
(0.0068)\end{array}$ & $\begin{array}{c}0.0341^{* * *} \\
(0.0094)\end{array}$ & $\begin{array}{c}0.0365^{* * *} \\
(0.0086)\end{array}$ & $\begin{array}{c}0.0118 \\
(0.0165)\end{array}$ & $\begin{array}{l}0.022 \\
(0.0176)\end{array}$ & $\begin{array}{c}0.0295^{*} \\
(0.0165)\end{array}$ & $\begin{array}{c}0.0360^{* *} \\
(0.0162)\end{array}$ \\
\hline EV*Poor People (\%) & $\begin{array}{c}-0.0128^{* * *} \\
(0.0049)\end{array}$ & & $\begin{array}{c}-0.00758 \\
(0.0051)\end{array}$ & & $\begin{array}{c}0.0139 \\
(0.0149)\end{array}$ & & $\begin{array}{c}-0.000968 \\
(0.0154)\end{array}$ & \\
\hline Year $=1998^{*}$ Poor People $(\%)$ & $\begin{array}{c}0.00204 \\
(0.0029)\end{array}$ & $\begin{array}{c}0.000992 \\
(0.0029)\end{array}$ & $\begin{array}{c}0.00440^{* *} \\
(0.0018)\end{array}$ & $\begin{array}{c}0.00488^{* * *} \\
(0.0017)\end{array}$ & $\begin{array}{c}0.00143 \\
(0.0068)\end{array}$ & $\begin{array}{c}0.00255 \\
(0.0068)\end{array}$ & $\begin{array}{c}0.000081 \\
(0.0066)\end{array}$ & $\begin{array}{c}0.00226 \\
(0.0062)\end{array}$ \\
\hline Years of study & $\begin{array}{c}0.00113 \\
(0.0028)\end{array}$ & & $\begin{array}{c}0.00538^{* *} \\
(0.0025)\end{array}$ & & $\begin{array}{c}0.00881 \\
(0.0084)\end{array}$ & & $\begin{array}{c}0.0123 \\
(0.0075)\end{array}$ & \\
\hline EV $(98)^{*}$ Years of study & $\begin{array}{c}-0.00761 \\
(0.0061)\end{array}$ & $\begin{array}{c}-0.00994^{*} \\
(0.0055)\end{array}$ & $\begin{array}{c}-0.0114 \\
(0.0086)\end{array}$ & $\begin{array}{c}-0.00912 \\
(0.0083)\end{array}$ & $\begin{array}{c}0.00283 \\
(0.0146)\end{array}$ & $\begin{array}{c}0.00776 \\
(0.0152)\end{array}$ & $\begin{array}{c}-0.00299 \\
(0.0139)\end{array}$ & $\begin{array}{c}0.00224 \\
(0.0136)\end{array}$ \\
\hline $\mathrm{EV}^{*}$ Years of study & $\begin{array}{c}-0.0111^{* *} \\
(0.0046)\end{array}$ & & $\begin{array}{c}-0.00695 \\
(0.0046)\end{array}$ & & $\begin{array}{c}0.00764 \\
(0.0126)\end{array}$ & & $\begin{array}{c}0.0065 \\
(0.0129)\end{array}$ & \\
\hline Year $=1998^{*}$ Years of study & $\begin{array}{c}-0.00716^{* *} \\
(0.0030)\end{array}$ & $\begin{array}{c}-0.00653^{* *} \\
(0.0029)\end{array}$ & $\begin{array}{c}-0.00131 \\
(0.0018)\end{array}$ & $\begin{array}{c}-0.000479 \\
(0.0018)\end{array}$ & $\begin{array}{c}-0.00531 \\
(0.0063)\end{array}$ & $\begin{array}{c}-0.00305 \\
(0.0061)\end{array}$ & $\begin{array}{c}-0.00622 \\
(0.0065)\end{array}$ & $\begin{array}{c}-0.00548 \\
(0.0064)\end{array}$ \\
\hline Constant & $\begin{array}{c}0.0923^{* * *} \\
(0.0051)\end{array}$ & $\begin{array}{c}0.0902^{* * *} \\
(0.0055)\end{array}$ & $\begin{array}{c}0.0579^{* * *} \\
(0.0045) \\
\end{array}$ & $\begin{array}{c}0.0768^{* * *} \\
(0.0069) \\
\end{array}$ & $\begin{array}{c}0.180 * * * \\
(0.0165)\end{array}$ & $\begin{array}{c}0.224^{* * *} \\
(0.0146) \\
\end{array}$ & $\begin{array}{c}0.115^{* * *} \\
(0.0147) \\
\end{array}$ & $\begin{array}{c}0.177^{* * *} \\
(0.0110)\end{array}$ \\
\hline Observations & 1074 & $\begin{array}{r}1074 \\
\text { Robus } \\
* * *\end{array}$ & $\begin{array}{c}1074 \\
\text { adard er } \\
.01,{ }^{* *}\end{array}$ & $\begin{array}{c}1074 \\
n \text { paren } \\
5, * \mathrm{p}<\end{array}$ & 1074 & 1074 & 1074 & 1074 \\
\hline
\end{tabular}

(1) Pooled regression; (2) Fixed Effects

Using average years of schooling, percentage of poor people, longevity HDI, inequality (Theil Index), children mortality, house infrastructure (telephone and electricity), percentage of woman, mayor party,mayor vote share on the last election, number of electors (as deviation from the threshold), state/municipality fixed effects, electors age composition (young and elderly), political engagement as controls 
Table 44: Discontinuity - Electronic voting impact on Turnout

\begin{tabular}{|c|c|c|}
\hline \multicolumn{3}{|l|}{ Dep. Var.: Turnout } \\
\hline Regressions & (1) & (2) \\
\hline Electronic Voting (EV) & $\begin{array}{c}0.0136^{*} \\
(0.0079)\end{array}$ & \\
\hline Year $=1998$ & $\begin{array}{c}-0.0286^{* * *} \\
(0.0024)\end{array}$ & $\begin{array}{c}-0.0247^{* * *} \\
(0.0033)\end{array}$ \\
\hline EV * Year $=1998[\mathrm{EV}(98)]$ & $\begin{array}{c}-0.0217^{* * *} \\
(0.0047)\end{array}$ & $\begin{array}{c}-0.0191^{* * *} \\
(0.0033)\end{array}$ \\
\hline Poor People (\%) & $\begin{array}{c}-0.0261^{* * *} \\
(0.0084)\end{array}$ & \\
\hline EV $(98) *$ Poor People $(\%)$ & $\begin{array}{c}0.0369 * * * \\
(0.0093)\end{array}$ & $\begin{array}{c}0.0158^{* *} \\
(0.0063)\end{array}$ \\
\hline EV*Poor People $(\%)$ & $\begin{array}{c}0.00249 \\
(0.0106)\end{array}$ & \\
\hline Year $=1998^{*}$ Poor People $(\%)$ & $\begin{array}{c}-0.0048 \\
(0.0052)\end{array}$ & $\begin{array}{c}0.0023 \\
(0.0037)\end{array}$ \\
\hline Years of study & $\begin{array}{c}0.0256^{* * *} \\
(0.0079)\end{array}$ & \\
\hline EV $(98)^{*}$ Years of study & $\begin{array}{c}0.0285^{* * *} \\
(0.0094)\end{array}$ & $\begin{array}{c}0.0199 * * * \\
(0.0064)\end{array}$ \\
\hline $\mathrm{EV}^{*}$ Years of study & $\begin{array}{c}0.00503 \\
(0.0114)\end{array}$ & \\
\hline Year $=1998^{*}$ Years of study & $\begin{array}{c}-0.00597 \\
(0.0054)\end{array}$ & $\begin{array}{c}-0.000278 \\
(0.0035)\end{array}$ \\
\hline Constant & $\begin{array}{c}0.685^{* * *} \\
(0.0228)\end{array}$ & $\begin{array}{c}0.778^{* * *} \\
(0.0092)\end{array}$ \\
\hline Observations & 1074 & 1074 \\
\hline
\end{tabular}

Using average years of schooling, percentage of poor people, longevity HDI, inequality (Theil Index), children mortality, house infrastructure (telephone and electricity), percentage of woman, mayor party, mayor vote share on the last election, number of electors (as deviation from the threshold), state/municipality fixed effects,electors age composition (young and elderly), political engagement as controls 
Table 45: Discontinuity - Electronic voting impact on Party Votes

\begin{tabular}{|c|c|c|c|c|}
\hline \multirow{3}{*}{$\begin{array}{l}\text { Dep. Var.: Party Vote } \\
\text { Regressions } \\
\text { Electronic Voting (EV) }\end{array}$} & \multicolumn{2}{|c|}{ Federal Deputy } & \multicolumn{2}{|c|}{ State Deputy } \\
\hline & (1) & (2) & (1) & (2) \\
\hline & $\begin{array}{c}-0.00092 \\
(0.0078)\end{array}$ & & $\begin{array}{c}-0.00368 \\
(0.0066)\end{array}$ & \\
\hline Year $=1998$ & $\begin{array}{c}0.00478^{* *} \\
(0.0023)\end{array}$ & $\begin{array}{c}0.00391 \\
(0.0033)\end{array}$ & $\begin{array}{c}0.00697^{* * *} \\
(0.0021)\end{array}$ & $\begin{array}{c}0.00579^{* *} \\
(0.0027)\end{array}$ \\
\hline $\mathrm{EV} *$ Year $=1998[\mathrm{EV}(98)]$ & $\begin{array}{c}0.111^{* * *} \\
(0.0122)\end{array}$ & $\begin{array}{c}0.126^{* * *} \\
(0.0125)\end{array}$ & $\begin{array}{c}0.159^{* * *} \\
(0.0107)\end{array}$ & $\begin{array}{c}0.156^{* * *} \\
(0.0119)\end{array}$ \\
\hline Poor People (\%) & $\begin{array}{c}-0.0251^{* * *} \\
(0.0061)\end{array}$ & & $\begin{array}{c}-0.0203^{* * *} \\
(0.0052)\end{array}$ & \\
\hline EV $(98) *$ Poor People (\%) & $\begin{array}{c}0.0276 \\
(0.0169)\end{array}$ & $\begin{array}{c}0.0261 \\
(0.0165)\end{array}$ & $\begin{array}{c}0.0118 \\
(0.0143)\end{array}$ & $\begin{array}{c}0.0105 \\
(0.0142)\end{array}$ \\
\hline EV*Poor People (\%) & $\begin{array}{c}-0.0105 \\
(0.0163)\end{array}$ & & $\begin{array}{c}-0.00664 \\
(0.0151)\end{array}$ & \\
\hline Year $=1998^{*}$ Poor People $(\%)$ & $\begin{array}{c}0.0238^{* * *} \\
(0.0049)\end{array}$ & $\begin{array}{c}0.0257^{* * *} \\
(0.0048)\end{array}$ & $\begin{array}{c}0.0212^{* * *} \\
(0.0044)\end{array}$ & $\begin{array}{c}0.0233^{* * *} \\
\quad(0.0042)\end{array}$ \\
\hline Years of study & $\begin{array}{c}-0.000333 \\
(0.0057)\end{array}$ & & $\begin{array}{c}0.000746 \\
(0.0045)\end{array}$ & \\
\hline EV $(98) *$ Years of study & $\begin{array}{c}0.00898 \\
(0.0148)\end{array}$ & $\begin{array}{c}0.00517 \\
(0.0138)\end{array}$ & $\begin{array}{c}-0.0123 \\
(0.0118)\end{array}$ & $\begin{array}{c}-0.0178^{*} \\
(0.0107)\end{array}$ \\
\hline $\mathrm{EV}^{*}$ Years of study & $\begin{array}{c}-0.0128 \\
(0.0149)\end{array}$ & & $\begin{array}{c}-0.00324 \\
(0.0134)\end{array}$ & \\
\hline Year $=1998^{*}$ Years of study & $\begin{array}{c}-0.00112 \\
(0.0044)\end{array}$ & $\begin{array}{l}0.002 \\
(0.0044)\end{array}$ & $\begin{array}{c}-0.000271 \\
(0.0036)\end{array}$ & $\begin{array}{c}0.00231 \\
(0.0037)\end{array}$ \\
\hline Constant & $\begin{array}{c}0.0262^{* * * *} \\
(0.0088)\end{array}$ & $\begin{array}{c}0.0543^{* * *} \\
(0.0101)\end{array}$ & $\begin{array}{c}0.0140^{*} \\
(0.0080)\end{array}$ & $\begin{array}{c}0.0437^{* * *} \\
(0.0073)\end{array}$ \\
\hline Observations & 1074 & 1074 & 1074 & 1074 \\
\hline
\end{tabular}

$$
\text { *** } \mathrm{p}<0.01, * * \mathrm{p}<0.05, * \mathrm{p}<0.1
$$

(1) Pooled regression; (2) Fixed Effects

Using average years of schooling, percentage of poor people, longevity HDI, inequality (Theil Index), children mortality, house infrastructure (telephone and electricity), percentage of woman, mayor party, mayor vote share on the last election, number of electors (as deviation from the threshold), state/municipality fixed effects,electors age composition (young and elderly), political engagement as controls 
Table 46: Discontinuity - Electronic voting impact on Party Fractionalization

\begin{tabular}{|c|c|c|c|c|c|c|c|c|}
\hline \multirow{2}{*}{$\begin{array}{l}\text { Dep. Var.: Fractionalization (party) } \\
\text { Regressions }\end{array}$} & \multicolumn{2}{|c|}{ President } & \multicolumn{2}{|c|}{ Governor } & \multicolumn{2}{|c|}{ Federal Deputy } & \multicolumn{2}{|c|}{ State Deputy } \\
\hline & (1) & (2) & 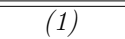 & (2) & (1) & (2) & (1) & (2) \\
\hline \multirow[t]{2}{*}{ Electronic Voting (EV) } & 0.00358 & & 0.0951 & & $-0.276^{*}$ & & -0.229 & \\
\hline & $(0.1290)$ & & $(0.1320)$ & & $(0.1640)$ & & $(0.1570)$ & \\
\hline \multirow[t]{2}{*}{ Year $=1998$} & 0.0482 & 0.0256 & 0.0794 & $0.154^{*}$ & $-0.310^{* *}$ & -0.287 & $-0.454^{* * *}$ & $-0.405^{* *}$ \\
\hline & $(0.0560)$ & $(0.0766)$ & $(0.0586)$ & $(0.0850)$ & $(0.1400)$ & $(0.1740)$ & $(0.1650)$ & $(0.2030)$ \\
\hline \multirow[t]{2}{*}{ EV * Year $=1998[\mathrm{EV}(98)]$} & $-0.588^{* * *}$ & $-0.527^{* * *}$ & -0.294 & -0.253 & $1.172^{* * *}$ & $1.037^{* * *}$ & $0.799^{* * *}$ & $0.703^{* * *}$ \\
\hline & $(0.1530)$ & $(0.1570)$ & $(0.1790)$ & $(0.2050)$ & $(0.1730)$ & $(0.1940)$ & $(0.1830)$ & $(0.2050)$ \\
\hline \multirow[t]{2}{*}{ Poor People (\%) } & -0.0558 & & 0.19 & & -0.189 & & -0.221 & \\
\hline & $(0.1290)$ & & $(0.1190)$ & & $(0.1350)$ & & $(0.1390)$ & \\
\hline \multirow[t]{2}{*}{ EV $(98)^{*}$ Poor People (\%) } & 0.141 & 0.258 & -0.301 & -0.237 & 0.172 & 0.00607 & -0.286 & -0.441 \\
\hline & $(0.2550)$ & $(0.2630)$ & $(0.2740)$ & $(0.2940)$ & $(0.3270)$ & $(0.3260)$ & $(0.3290)$ & $(0.3480)$ \\
\hline \multirow[t]{2}{*}{ EV*Poor People (\%) } & -0.13 & & 0.31 & & -0.084 & & -0.0735 & \\
\hline & $(0.2030)$ & & $(0.2070)$ & & $(0.2560)$ & & $(0.2530)$ & \\
\hline \multirow[t]{2}{*}{ Year $=1998^{*}$ Poor People $(\%)$} & $0.449 * * *$ & $0.403^{* * *}$ & $-0.499 * * *$ & $-0.565^{* * *}$ & 0.246 & 0.241 & $0.463^{* * *}$ & $0.449^{* *}$ \\
\hline & $(0.1130)$ & $(0.1140)$ & $(0.1260)$ & $(0.1250)$ & $(0.1780)$ & $(0.1780)$ & $(0.1770)$ & $(0.1790)$ \\
\hline \multirow[t]{2}{*}{ Years of study } & $0.553^{* * *}$ & & $0.316^{* * *}$ & & $-0.256^{* *}$ & & $-0.370^{* * *}$ & \\
\hline & $(0.1130)$ & & $(0.1030)$ & & $(0.1300)$ & & $(0.1280)$ & \\
\hline \multirow[t]{2}{*}{ EV $(98)^{*}$ Years of study } & -0.0344 & -0.00548 & -0.0893 & 0.0256 & -0.269 & -0.31 & $-0.593^{* *}$ & $-0.605^{*}$ \\
\hline & $(0.2640)$ & $(0.2640)$ & $(0.3440)$ & $(0.3680)$ & $(0.3010)$ & $(0.3200)$ & $(0.2950)$ & $(0.3160)$ \\
\hline \multirow[t]{2}{*}{ EV*Years of study } & -0.202 & & 0.083 & & -0.0212 & & 0.175 & \\
\hline & $(0.1760)$ & & $(0.2190)$ & & $(0.2360)$ & & $(0.2200)$ & \\
\hline \multirow[t]{2}{*}{ Year $=1998^{*}$ Years of study } & 0.0771 & 0.125 & $-0.270^{* *}$ & $-0.231^{*}$ & $0.639^{* * *}$ & $0.627^{* * *}$ & $0.920^{* * *}$ & $0.885^{* * *}$ \\
\hline & $(0.1190)$ & $(0.1160)$ & $(0.1240)$ & $(0.1240)$ & $(0.1630)$ & $(0.1620)$ & $(0.1650)$ & $(0.1640)$ \\
\hline \multirow[t]{2}{*}{ \# of parties } & - & - & $0.0521^{*}$ & 0.0388 & 0.00431 & -0.0128 & 0.0253 & 0.00794 \\
\hline & - & - & $(0.0314)$ & $(0.0338)$ & $(0.0190)$ & $(0.0203)$ & $(0.0219)$ & $(0.0228)$ \\
\hline \multirow[t]{2}{*}{ Constant } & 0.26 & 0.187 & $-1.334^{* * *}$ & $-0.594^{*}$ & 0.472 & 0.638 & 0.38 & 0.264 \\
\hline & $(0.2110)$ & $(0.2250)$ & $(0.2230)$ & $(0.3430)$ & $(0.4990)$ & $(0.5440)$ & $(0.4690)$ & $(0.5950)$ \\
\hline \multirow[t]{2}{*}{ Observations } & 1074 & 1074 & 1074 & 1074 & 1074 & 1074 & 1074 & 1074 \\
\hline & Robu & $\begin{array}{l}<0.01 \\
\text { d regres }\end{array}$ & $\begin{array}{l}\text { rors in pa } \\
0<0.05, * \\
n:(2) \text { Fix }\end{array}$ & $\begin{array}{l}\text { atheses } \\
0.1 \\
\text { Effects }\end{array}$ & & & & \\
\hline
\end{tabular}

Using average years of schooling, percentage of poor people, longevity HDI, inequality (Theil Index), children mortality, house infrastructure (telephone and electricity), percentage of woman, mayor party, mayor vote share on the last election, number of electors (as deviation from the threshold), state/municipality fixed effects,electors age composition (young and elderly), political engagement as controls 
Table 47: Discontinuity - Electronic voting impact on Candidate Fractionalization

\begin{tabular}{|c|c|c|c|c|}
\hline Dep. Var.: Fractionalization (cand.) & Federal & Deputy & State & Deputy \\
\hline Regressions & (1) & (2) & (1) & (2) \\
\hline Electronic Voting (EV) & -0.109 & & 0.179 & \\
\hline & $(0.1690)$ & & $(0.1740)$ & \\
\hline Year $=1998$ & -0.0851 & -0.127 & -0.0485 & -0.0704 \\
\hline & $(0.0744)$ & $(0.0868)$ & $(0.0794)$ & $(0.1000)$ \\
\hline EV $*$ Year $=1998[\mathrm{EV}(98)]$ & 0.236 & 0.199 & 0.0217 & -0.0944 \\
\hline & $(0.1480)$ & $(0.1590)$ & $(0.1450)$ & $(0.1580)$ \\
\hline Poor People (\%) & 0.217 & & $0.491^{* * *}$ & \\
\hline & $(0.1900)$ & & $(0.1790)$ & \\
\hline EV $(98) *$ Poor People $(\%)$ & -0.204 & -0.102 & -0.113 & -0.206 \\
\hline & $(0.2920)$ & $(0.3050)$ & $(0.2830)$ & $(0.2770)$ \\
\hline $\mathrm{EV}^{*}$ Poor People $(\%)$ & 0.37 & & 0.235 & \\
\hline & $(0.2390)$ & & $(0.2700)$ & \\
\hline Year $=1998 *$ Poor People $(\%)$ & $0.388^{* *}$ & $0.331^{*}$ & 0.0755 & 0.159 \\
\hline & $(0.1830)$ & $(0.1890)$ & $(0.1540)$ & $(0.1530)$ \\
\hline Years of study & $0.294^{*}$ & & $0.251^{*}$ & \\
\hline & $(0.1630)$ & & $(0.1480)$ & \\
\hline EV $(98)^{*}$ Years of study & 0.235 & 0.221 & -0.007 & 0.00621 \\
\hline & $(0.2600)$ & $(0.2490)$ & $(0.2150)$ & $(0.2160)$ \\
\hline $\mathrm{EV}^{*}$ Years of study & 0.152 & & $0.442^{*}$ & \\
\hline & $(0.2320)$ & & $(0.2270)$ & \\
\hline Year $=1998^{*}$ Years of study & 0.0307 & 0.0638 & 0.127 & 0.188 \\
\hline & $(0.1590)$ & $(0.1560)$ & $(0.1380)$ & $(0.1330)$ \\
\hline \# of candidates & $0.00235^{*}$ & 0.00183 & 0.000129 & 0.000383 \\
\hline & $(0.0013)$ & $(0.0014)$ & $(0.0004)$ & $(0.0004)$ \\
\hline Constant & 0.37 & -0.408 & 0.357 & -0.00333 \\
\hline & $(0.2470)$ & $(0.3340)$ & $(0.3620)$ & $(0.2620)$ \\
\hline Observations & 1074 & 1074 & 1074 & 1074 \\
\hline
\end{tabular}

(1) Pooled regression; (2) Fixed Effects

Using average years of schooling, percentage of poor people, longevity HDI, inequality (Theil Index), children mortality, house infrastructure (telephone and electricity), percentage of woman, mayor party, mayor vote share on the last election, number of electors (as deviation from the threshold), state/municipality fixed effects, electors age composition (young and elderly), political engagement as controls 
Table 48: Discontinuity - Electronic voting impact on Best Loser Votes (State Deputy Only)

\begin{tabular}{lcc}
\hline Dep. Var.: Best Loser & \multicolumn{2}{c}{ Vote Share } \\
\hline \hline Regressions & $(1)$ & $(2)$ \\
Electronic Voting $(\mathrm{EV})$ & -0.011 & \\
& $(0.0320)$ & \\
Year $=1998$ & -0.00395 & -0.00941 \\
& $(0.0138)$ & $(0.0186)$ \\
EV * Year=1998 [EV $(98)]$ & 0.00587 & 0.0222 \\
& $(0.0302)$ & $(0.0318)$ \\
$(=1)$ Mayor Party & $0.0685^{* * *}$ & $0.0606^{* *}$ \\
& $(0.0180)$ & $(0.0241)$ \\
Mayor Popularity & -0.00721 & -0.0146 \\
& $(0.0129)$ & $(0.0148)$ \\
EV $(98) *$ Poor People $(\%)$ & 0.0725 & 0.0565 \\
& $(0.0558)$ & $(0.0587)$ \\
Constant & $0.315^{* * *}$ & $0.240^{* * *}$ \\
& $(0.0358)$ & $(0.0540)$ \\
Constant & $0.315^{* * *}$ & $0.240^{* * *}$ \\
& $(0.0358)$ & $(0.0540)$ \\
\hline Observations & 1070 & 1070 \\
Robust standard errors in parentheses \\
$* * *$ p $<0.01, * *$ p $<0.05, *$ p $<0.1$
\end{tabular}

(1) Pooled regression; (2) Fixed Effects

Using average years of schooling, percentage of poor people, longevity HDI, inequality (Theil Index), children mortality, house infrastructure (telephone and electricity), percentage of woman, mayor party, mayor vote share on the last election, number of electors (as deviation from the threshold), state/municipality fixed effects, electors age composition (young and elderly), political engagement as controls 
Table 49: Discontinuity - Electronic voting impact on Invalid Votes (Considering vote order)

\begin{tabular}{|c|c|c|}
\hline Dep. Var.: Invalid & & \\
\hline Regressions & $\overline{(1)}$ & $\overline{(2)}$ \\
\hline Electronic Voting (EV) & -0.00112 & \\
\hline & $(0.0049)$ & \\
\hline Year $=1998$ & $-0.00286^{*}$ & -0.00271 \\
\hline & $(0.0017)$ & $(0.0023)$ \\
\hline $\mathrm{EV} * \operatorname{Year}=1998[\mathrm{EV}(98)]$ & $-0.112^{* * *}$ & $-0.115^{* * *}$ \\
\hline & $(0.0058)$ & $(0.0059)$ \\
\hline Poor People (\%) & $0.0245 * * *$ & \\
\hline & $(0.0052)$ & \\
\hline EV(98)*Poor People (\%) & $-0.0170^{*}$ & $-0.0202^{* *}$ \\
\hline & $(0.0089)$ & $(0.0091)$ \\
\hline $\mathrm{EV}^{*}$ Poor People $(\%)$ & $-0.0175^{* *}$ & \\
\hline & $(0.0069)$ & \\
\hline Year $=1998^{*}$ Poor People $(\%)$ & $-0.0111^{* * *}$ & $-0.00881^{* *}$ \\
\hline & $(0.0039)$ & $(0.0038)$ \\
\hline Years of study & $-0.0128 * * *$ & \\
\hline & $(0.0048)$ & \\
\hline $\mathrm{EV}(98)^{*}$ Years of study & $0.0591^{* * *}$ & $0.0561^{* * *}$ \\
\hline & $(0.0089)$ & $(0.0085)$ \\
\hline EV*Years of study & $-0.0165 * *$ & \\
\hline & $(0.0071)$ & \\
\hline Year $=1998^{*}$ Years of study & $-0.0142^{* * *}$ & $-0.0119 * * *$ \\
\hline & $(0.0044)$ & $(0.0043)$ \\
\hline Constant & $0.161^{* * *}$ & $0.224^{* * *}$ \\
\hline & $(0.0089)$ & $(0.0072)$ \\
\hline Observations & 1074 & 1074 \\
\hline $\begin{array}{l}\text { Robust standard err } \\
\quad * * * \mathrm{p}<0.01,{ }^{* *} \mathrm{p} \\
\text { (1) Pooled regression }\end{array}$ & $\begin{array}{l}\text { s in parentl } \\
0.05,{ }^{*} \mathrm{p}<0 \\
\text { (2) Fixed E }\end{array}$ & eses \\
\hline
\end{tabular}


Table 50: Discontinuity - Electronic voting impact on PT party code votes (over total party code votes)

\begin{tabular}{|c|c|c|c|c|c|c|c|c|}
\hline \multirow{2}{*}{$\begin{array}{l}\text { Dep. Var.: PT Party Code Vote Share } \\
\text { Regressions }\end{array}$} & \multicolumn{2}{|c|}{ President } & \multicolumn{2}{|c|}{ Governor } & \multicolumn{2}{|c|}{ Federal Deputy } & \multicolumn{2}{|c|}{ State Deputy } \\
\hline & (1) & (2) & (1) & (2) & (1) & (2) & (1) & (2) \\
\hline Electronic Voting (EV) & $0.0295^{* *}$ & & 0.00553 & & 0.0328 & & 0.0286 & \\
\hline & (1) & (2) & (1) & (2) & (1) & (2) & (1) & (2) \\
\hline Year $=1998$ & $\begin{array}{c}0.0442^{* * *} \\
(0.0049)\end{array}$ & $\begin{array}{c}0.0519^{* * *} \\
(0.0063)\end{array}$ & $\begin{array}{c}0.0649^{* * *} \\
(0.0056)\end{array}$ & $\begin{array}{c}0.0750^{* * *} \\
(0.0086)\end{array}$ & $\begin{array}{c}-0.202^{* * *} \\
(0.0091)\end{array}$ & $\begin{array}{c}-0.176^{* * *} \\
(0.0133)\end{array}$ & $\begin{array}{c}-0.210^{* * *} \\
(0.0095)\end{array}$ & $\begin{array}{c}-0.193^{* * *} \\
(0.0134)\end{array}$ \\
\hline EV * Year $=1998[$ EV $(98)]$ & $\begin{array}{c}-0.0215^{*} \\
(0.0112)\end{array}$ & $\begin{array}{c}-0.00673 \\
(0.0123)\end{array}$ & $\begin{array}{c}0.00384 \\
(0.0130)\end{array}$ & $\begin{array}{c}0.00357 \\
(0.0140)\end{array}$ & $\begin{array}{c}-0.0808^{* * *} \\
(0.0236)\end{array}$ & $\begin{array}{c}-0.0697^{* * *} \\
(0.0246)\end{array}$ & $\begin{array}{c}-0.0997^{* * *} \\
(0.0266)\end{array}$ & $\begin{array}{c}-0.0912^{* * *} \\
(0.0286)\end{array}$ \\
\hline Poor People (\%) & $\begin{array}{l}0.0119 \\
(0.0140)\end{array}$ & & $\begin{array}{c}0.00229 \\
(0.0129)\end{array}$ & & $\begin{array}{l}0.0201 \\
(0.0228)\end{array}$ & & $\begin{array}{l}0.0325 \\
(0.0225)\end{array}$ & \\
\hline EV $(98) *$ Poor People (\%) & $\begin{array}{c}-0.0111 \\
(0.0230)\end{array}$ & $\begin{array}{c}0.00877 \\
(0.0234)\end{array}$ & $\begin{array}{c}-0.0153 \\
(0.0261)\end{array}$ & $\begin{array}{c}-0.0486 \\
(0.0339)\end{array}$ & $\begin{array}{c}0.00955 \\
(0.0439)\end{array}$ & $\begin{array}{l}0.0438 \\
(0.0419)\end{array}$ & $\begin{array}{l}0.036 \\
(0.0451)\end{array}$ & $\begin{array}{c}0.0641 \\
(0.0466)\end{array}$ \\
\hline EV*Poor People (\%) & $\begin{array}{c}0.00524 \\
(0.0253)\end{array}$ & & $\begin{array}{c}0.0393 \\
(0.0264)\end{array}$ & & $\begin{array}{c}0.00766 \\
(0.0375)\end{array}$ & & $\begin{array}{c}0.00163 \\
(0.0372)\end{array}$ & \\
\hline Year $=1998^{*}$ Poor People $(\%)$ & $\begin{array}{c}0.0551^{* * *} \\
(0.0100)\end{array}$ & $\begin{array}{c}0.0482^{* * *} \\
(0.0089)\end{array}$ & $\begin{array}{c}0.00189 \\
(0.0109)\end{array}$ & $\begin{array}{c}0.000175 \\
(0.0116)\end{array}$ & $\begin{array}{c}-0.0435^{* *} \\
(0.0213)\end{array}$ & $\begin{array}{c}-0.0550^{* * * *} \\
(0.0194)\end{array}$ & $\begin{array}{c}-0.0565^{* * *} \\
(0.0209)\end{array}$ & $\begin{array}{c}-0.0676^{* * *} \\
(0.0203)\end{array}$ \\
\hline EV $(98)^{*}$ Years of study & $\begin{array}{c}-0.0172 \\
(0.0224)\end{array}$ & $\begin{array}{c}-0.0171 \\
(0.0231)\end{array}$ & $\begin{array}{c}0.0118 \\
(0.0278)\end{array}$ & $\begin{array}{c}0.00221 \\
(0.0353)\end{array}$ & $\begin{array}{c}0.0133 \\
(0.0392)\end{array}$ & $\begin{array}{c}0.0208 \\
(0.0391)\end{array}$ & $\begin{array}{c}0.0514 \\
(0.0413)\end{array}$ & $\begin{array}{c}0.0535 \\
(0.0422)\end{array}$ \\
\hline Mayor $(\mathrm{PT}=1)$ & $\begin{array}{c}0.0313 \\
(0.0282)\end{array}$ & $\begin{array}{c}-0.0123 \\
(0.0204)\end{array}$ & $\begin{array}{c}0.0715^{* *} \\
(0.0284)\end{array}$ & $\begin{array}{c}0.0375^{* *} \\
(0.0180)\end{array}$ & $\begin{array}{c}-0.0183 \\
(0.0309)\end{array}$ & $\begin{array}{l}-0.058 \\
(0.0405)\end{array}$ & $\begin{array}{c}-0.0196 \\
(0.0399)\end{array}$ & $\begin{array}{c}-0.0159 \\
(0.0490)\end{array}$ \\
\hline Year $=1998 *$ Mayor $(\mathrm{PT}=1)$ & $\begin{array}{c}-0.034 \\
(0.0383)\end{array}$ & $\begin{array}{c}-0.0605^{* *} \\
(0.0299)\end{array}$ & $\begin{array}{c}-0.0536 \\
(0.0403)\end{array}$ & $\begin{array}{c}-0.122^{* * *} \\
(0.0203)\end{array}$ & $\begin{array}{l}0.0257 \\
(0.0538)\end{array}$ & $\begin{array}{c}-0.0422 \\
(0.0617)\end{array}$ & $\begin{array}{l}0.0121 \\
(0.0611)\end{array}$ & $\begin{array}{c}-0.0831 \\
(0.0712)\end{array}$ \\
\hline $\mathrm{EV}^{*}$ Mayor $(\mathrm{PT}=1)$ & $\begin{array}{c}-0.00113 \\
(0.0409)\end{array}$ & $\begin{array}{c}-0.0369 \\
(0.0279)\end{array}$ & $\begin{array}{c}-0.0663^{* *} \\
(0.0331)\end{array}$ & $\begin{array}{c}-0.0664^{* *} \\
(0.0309)\end{array}$ & $\begin{array}{c}0.0414 \\
(0.0747)\end{array}$ & $\begin{array}{l}0.043 \\
(0.0643)\end{array}$ & $\begin{array}{c}0.0386 \\
(0.0766)\end{array}$ & $\begin{array}{c}-0.0649 \\
(0.0618)\end{array}$ \\
\hline $\mathrm{EV}(98) *$ Mayor $(\mathrm{PT}=1)$ & $\begin{array}{r}-0.061 \\
(0.0560)\end{array}$ & $\begin{array}{c}-0.0219 \\
(0.0410)\end{array}$ & $\begin{array}{l}0.0216 \\
(0.0542)\end{array}$ & $\begin{array}{l}0.0377 \\
(0.0448)\end{array}$ & $\begin{array}{l}-0.127 \\
(0.0906)\end{array}$ & $\begin{array}{c}-0.0787 \\
(0.1020)\end{array}$ & $\begin{array}{c}-0.0846 \\
(0.0954)\end{array}$ & $\begin{array}{l}0.0805 \\
(0.0977)\end{array}$ \\
\hline Constant & $\begin{array}{c}0.270^{* * *} \\
(0.0451)\end{array}$ & $\begin{array}{c}0.215^{* * *} \\
(0.0205)\end{array}$ & $\begin{array}{c}0.0749^{* * *} \\
(0.0220)\end{array}$ & $\begin{array}{c}0.0820^{* * *} * \\
(0.0235)\end{array}$ & $\begin{array}{c}0.450^{* * * *} \\
(0.0670)\end{array}$ & $\begin{array}{c}0.370^{* * *} * \\
(0.0415)\end{array}$ & $\begin{array}{c}0.436^{* * *} \\
(0.0705)\end{array}$ & $\begin{array}{c}0.394^{* * *} \\
(0.0426)\end{array}$ \\
\hline Observations & 1074 & 1074 & 769 & 769 & 1074 & 1074 & 1074 & 1074 \\
\hline
\end{tabular}

(1) Pooled regression; (2) Fixed Effects

Using average years of schooling, percentage of poor people, longevity HDI, inequality (Theil Index), children mortality, house infrastructure (telephone and electricity), percentage of woman, mayor party,mayor vote share on the last election, number of electors (as deviation from the threshold), state/municipality fixed effects, electors age composition (young and elderly), political engagement as controls 
Table 51: Discontinuity - Electronic voting impact on PSDB Votes party code votes (over total party code votes)

\begin{tabular}{|c|c|c|c|c|c|c|c|c|}
\hline Dep. Var.: PSDB Party Code Vote Share & Pres & ident & Gov & rnor & Federa & Deputy & State & Deputy \\
\hline Regressions & (1) & (2) & (1) & (2) & (1) & (2) & (1) & (2) \\
\hline Electronic Voting (EV) & $\begin{array}{c}-0.0192 \\
(0.0182)\end{array}$ & & $\begin{array}{c}-0.00427 \\
(0.0214)\end{array}$ & & $\begin{array}{c}-0.00987 \\
(0.0135)\end{array}$ & & $\begin{array}{c}0.00214 \\
(0.0125)\end{array}$ & \\
\hline Year $=1998$ & $\begin{array}{c}-0.0334^{* * *} \\
(0.0074)\end{array}$ & $\begin{array}{c}-0.0314^{* * *} \\
(0.0096)\end{array}$ & $\begin{array}{c}-0.00658 \\
(0.0168)\end{array}$ & $\begin{array}{c}0.000335 \\
(0.0242)\end{array}$ & $\begin{array}{c}0.106^{* * *} \\
(0.0073)\end{array}$ & $\begin{array}{c}0.101^{* * *} \\
(0.0097)\end{array}$ & $\begin{array}{c}0.106^{* * *} \\
(0.0073)\end{array}$ & $\begin{array}{c}0.101^{* * *} \\
(0.0111)\end{array}$ \\
\hline EV $*$ Year $=1998[\mathrm{EV}(98)]$ & $\begin{array}{c}0.0523^{* * *} \\
(0.0178)\end{array}$ & $\begin{array}{c}0.0435^{* *} \\
(0.0179)\end{array}$ & $\begin{array}{c}0.0467^{*} \\
(0.0259)\end{array}$ & $\begin{array}{c}0.0132 \\
(0.0312)\end{array}$ & $\begin{array}{c}-0.00555 \\
(0.0154)\end{array}$ & $\begin{array}{c}-0.0121 \\
(0.0159)\end{array}$ & $\begin{array}{c}0.0491^{* * *} \\
(0.0156)\end{array}$ & $\begin{array}{c}0.0474^{* * *} \\
(0.0166)\end{array}$ \\
\hline Poor People (\%) & $\begin{array}{c}-0.0119 \\
(0.0160)\end{array}$ & & $\begin{array}{c}-0.111^{* * *} \\
(0.0267)\end{array}$ & & $\begin{array}{c}0.0243 \\
(0.0148)\end{array}$ & & $\begin{array}{c}0.0111 \\
(0.0122)\end{array}$ & \\
\hline EV $(98) *$ Poor People $(\%)$ & $\begin{array}{c}-0.0131 \\
(0.0317)\end{array}$ & $\begin{array}{c}-0.0382 \\
(0.0297)\end{array}$ & $\begin{array}{c}-0.00545 \\
(0.0489)\end{array}$ & $\begin{array}{c}-0.0997 \\
(0.0634)\end{array}$ & $\begin{array}{c}0.00267 \\
(0.0271)\end{array}$ & $\begin{array}{c}0.000861 \\
(0.0269)\end{array}$ & $\begin{array}{c}0.0564^{* *} \\
(0.0282)\end{array}$ & $\begin{array}{c}0.0539^{*} \\
(0.0286)\end{array}$ \\
\hline EV*Poor People (\%) & $\begin{array}{c}0.00948 \\
(0.0293)\end{array}$ & & $\begin{array}{c}-0.0335 \\
(0.0370)\end{array}$ & & $\begin{array}{c}-0.0107 \\
(0.0215)\end{array}$ & & $\begin{array}{c}-0.0174 \\
(0.0214)\end{array}$ & \\
\hline Year $=1998^{*}$ Poor People $(\%)$ & $\begin{array}{c}-0.0656^{* * *} \\
(0.0146)\end{array}$ & $\begin{array}{c}-0.0600^{* * *} \\
(0.0139)\end{array}$ & $\begin{array}{c}0.241 * * * \\
(0.0265)\end{array}$ & $\begin{array}{c}0.301^{* * *} \\
(0.0336)\end{array}$ & $\begin{array}{c}-0.0171 \\
(0.0157)\end{array}$ & $\begin{array}{c}-0.0206 \\
(0.0158)\end{array}$ & $\begin{array}{c}0.000504 \\
(0.0159)\end{array}$ & $\begin{array}{c}0.00507 \\
(0.0160)\end{array}$ \\
\hline EV $(98)^{*}$ Years of study & $\begin{array}{c}-0.0291 \\
(0.0305)\end{array}$ & $\begin{array}{c}-0.0361 \\
(0.0294)\end{array}$ & $\begin{array}{c}-0.0598 \\
(0.0557)\end{array}$ & $\begin{array}{c}-0.130^{*} \\
(0.0672)\end{array}$ & $\begin{array}{c}0.0167 \\
(0.0253)\end{array}$ & $\begin{array}{c}0.00705 \\
(0.0261)\end{array}$ & $\begin{array}{c}0.0218 \\
(0.0240)\end{array}$ & $\begin{array}{c}0.0187 \\
(0.0256)\end{array}$ \\
\hline Mayor $(\mathrm{PSDB}=1)$ & $\begin{array}{c}0.0447^{* *} \\
(0.0227)\end{array}$ & $\begin{array}{c}0.0506^{* *} \\
(0.0217)\end{array}$ & $\begin{array}{c}-0.00384 \\
(0.0232)\end{array}$ & $\begin{array}{c}-0.0890^{* *} \\
(0.0430)\end{array}$ & $\begin{array}{c}0.0442^{* *} \\
(0.0223)\end{array}$ & $\begin{array}{c}0.00125 \\
(0.0240)\end{array}$ & $\begin{array}{c}0.0546^{* * *} \\
(0.0190)\end{array}$ & $\begin{array}{l}0.0101 \\
(0.0274)\end{array}$ \\
\hline Year $=1998^{*}$ Mayor $(\mathrm{PSDB}=1)$ & $\begin{array}{c}-0.0708^{* * *} \\
(0.0259)\end{array}$ & $\begin{array}{c}-0.104^{* * *} \\
(0.0246)\end{array}$ & $\begin{array}{c}-0.0135 \\
(0.0271)\end{array}$ & $\begin{array}{l}0.0347 \\
(0.0473)\end{array}$ & $\begin{array}{c}-0.00242 \\
(0.0245)\end{array}$ & $\begin{array}{c}0.0326 \\
(0.0262)\end{array}$ & $\begin{array}{c}-0.0126 \\
(0.0215)\end{array}$ & $\begin{array}{c}0.0324 \\
(0.0296)\end{array}$ \\
\hline $\mathrm{EV}^{*}$ Mayor $(\mathrm{PSDB}=1)$ & $\begin{array}{c}-0.00321 \\
(0.0353)\end{array}$ & $\begin{array}{l}0.0357 \\
(0.0407)\end{array}$ & $\begin{array}{c}0.0781^{* *} \\
(0.0321)\end{array}$ & $\begin{array}{c}0.148^{* *} \\
(0.0611)\end{array}$ & $\begin{array}{c}-0.0331 \\
(0.0288)\end{array}$ & $\begin{array}{l}0.0367 \\
(0.0359)\end{array}$ & $\begin{array}{c}-0.0665 * * \\
(0.0258)\end{array}$ & $\begin{array}{c}0.000798 \\
(0.0352)\end{array}$ \\
\hline $\mathrm{EV}(98) *$ Mayor $(\mathrm{PSDB}=1)$ & $\begin{array}{c}-0.00538 \\
(0.0440)\end{array}$ & $\begin{array}{c}-0.0221 \\
(0.0475)\end{array}$ & $\begin{array}{c}-0.0842^{*} \\
(0.0439)\end{array}$ & $\begin{array}{c}-0.0785 \\
(0.0728)\end{array}$ & $\begin{array}{c}-0.0693^{*} \\
(0.0371)\end{array}$ & $\begin{array}{c}-0.0962^{* *} \\
(0.0415)\end{array}$ & $\begin{array}{c}-0.0115 \\
(0.0344)\end{array}$ & $\begin{array}{c}-0.0536 \\
(0.0387)\end{array}$ \\
\hline Constant & $\begin{array}{c}0.569^{* * *} \\
(0.0367) \\
\end{array}$ & $\begin{array}{c}0.582^{* * *} \\
(0.0261) \\
\end{array}$ & $\begin{array}{c}0.0597^{*} \\
(0.0358)\end{array}$ & $\begin{array}{c}0.376^{* * *} \\
(0.0642) \\
\end{array}$ & $\begin{array}{c}0.0546^{* *} \\
(0.0260) \\
\end{array}$ & $\begin{array}{c}0.164^{* * *} \\
(0.0256)\end{array}$ & $\begin{array}{c}0.00523 \\
(0.0229) \\
\end{array}$ & $\begin{array}{c}0.123^{* * *} \\
(0.0306) \\
\end{array}$ \\
\hline Observations & 1074 & 1074 & 625 & 625 & 1074 & 1074 & 1074 & 1074 \\
\hline
\end{tabular}

(1) Pooled regression; (2) Fixed Effects

Using average years of schooling, percentage of poor people, longevity HDI, inequality (Theil Index), children mortality, house infrastructure (telephone and electricity), percentage of woman, mayor party, mayor vote share on the last election, number of electors (as deviation from the threshold), state/municipality fixed effects, electors age composition (young and elderly), political engagement as controls 
Table 52: Discontinuity - Electronic voting impact on PMDB Votes party code votes (over total party code votes)

\begin{tabular}{|c|c|c|c|c|c|c|}
\hline \multirow{2}{*}{$\begin{array}{l}\text { Dep. Var.: PMDB Party Code Vote Share } \\
\text { Regressions }\end{array}$} & \multicolumn{2}{|c|}{ Governor } & \multicolumn{2}{|c|}{ Federal Deputy } & \multicolumn{2}{|c|}{ State Deputy } \\
\hline & $(1)$ & (2) & $(1)$ & 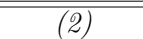 & (1) & 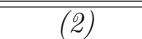 \\
\hline \multirow[t]{2}{*}{ Electronic Voting (EV) } & 0.0228 & & $0.0292^{* *}$ & & 0.0223 & \\
\hline & $(0.0266)$ & & $(0.0143)$ & & $(0.0150)$ & \\
\hline \multirow{2}{*}{ Year $=1998$} & $0.112^{* * *}$ & $0.100^{* * *}$ & $0.0456^{* * *}$ & $0.0287^{* *}$ & $0.0382^{* * *}$ & $0.0271^{* *}$ \\
\hline & $(0.0190)$ & $(0.0294)$ & $(0.0075)$ & $(0.0112)$ & $(0.0074)$ & $(0.0116)$ \\
\hline \multirow[t]{2}{*}{$\mathrm{EV} *$ Year $=1998[\mathrm{EV}(98)]$} & -0.0288 & -0.0417 & $-0.0818^{* * *}$ & $-0.0907^{* * *}$ & $-0.0480 * * *$ & $-0.0543^{* * *}$ \\
\hline & $(0.0433)$ & $(0.0651)$ & $(0.0144)$ & $(0.0154)$ & $(0.0151)$ & $(0.0155)$ \\
\hline \multirow[t]{2}{*}{ Poor People (\%) } & $-0.0990 * * *$ & & $-0.0412^{* * *}$ & & $-0.0248^{*}$ & \\
\hline & $(0.0301)$ & & $(0.0140)$ & & $(0.0141)$ & \\
\hline \multirow[t]{2}{*}{ EV $(98) *$ Poor People (\%) } & 0.0816 & 0.102 & 0.00451 & 0.00998 & 0.00117 & 0.0229 \\
\hline & $(0.0757)$ & $(0.1060)$ & $(0.0287)$ & $(0.0280)$ & $(0.0290)$ & $(0.0314)$ \\
\hline \multirow[t]{2}{*}{ EV*Poor People (\%) } & -0.029 & & 0.0111 & & 0.0166 & \\
\hline & $(0.0465)$ & & $(0.0202)$ & & $(0.0221)$ & \\
\hline \multirow{2}{*}{ Year $=1998 *$ Poor People $(\%)$} & $0.145^{* * *}$ & $0.139^{* * *}$ & $0.0687^{* * *}$ & $0.0728^{* * *}$ & $0.0519^{* * *}$ & $0.0481^{* * *}$ \\
\hline & $(0.0413)$ & $(0.0467)$ & $(0.0143)$ & $(0.0139)$ & $(0.0133)$ & $(0.0141)$ \\
\hline \multirow[t]{2}{*}{ EV $(98) *$ Years of study } & 0.0159 & 0.0512 & 0.0052 & 0.00157 & -0.00124 & -0.00349 \\
\hline & $(0.0742)$ & $(0.0910)$ & $(0.0290)$ & $(0.0294)$ & $(0.0293)$ & $(0.0311)$ \\
\hline \multirow[t]{2}{*}{ Mayor $(\mathrm{PMDB}=1)$} & $0.0727^{* * *}$ & $0.0892^{* *}$ & $0.0435^{* * *}$ & $0.0332^{* *}$ & $0.0338 * * *$ & 0.00822 \\
\hline & $(0.0207)$ & $(0.0415)$ & $(0.0107)$ & $(0.0158)$ & $(0.0114)$ & $(0.0159)$ \\
\hline \multirow[t]{2}{*}{ Year $=1998 *$ Mayor $($ PMDB $=1)$} & $-0.0474^{*}$ & -0.0577 & -0.00688 & -0.0154 & 0.00124 & 0.000541 \\
\hline & $(0.0277)$ & $(0.0545)$ & $(0.0137)$ & $(0.0221)$ & $(0.0149)$ & $(0.0233)$ \\
\hline \multirow[t]{2}{*}{$\mathrm{EV}^{*}$ Mayor $(\mathrm{PMDB}=1)$} & 0.00392 & -0.0395 & -0.00504 & -0.0344 & 0.00258 & -0.00604 \\
\hline & $(0.0357)$ & $(0.0573)$ & $(0.0193)$ & $(0.0240)$ & $(0.0199)$ & $(0.0246)$ \\
\hline \multirow[t]{2}{*}{$\mathrm{EV}(98)^{*}$ Mayor $(\mathrm{PMDB}=1)$} & -0.0304 & 0.0204 & -0.0186 & 0.0229 & $-0.0464^{*}$ & -0.0258 \\
\hline & $(0.0559)$ & $(0.0949)$ & $(0.0289)$ & $(0.0328)$ & $(0.0278)$ & $(0.0343)$ \\
\hline \multirow[t]{2}{*}{ Constant } & $0.251^{* * *}$ & $0.223^{* * *}$ & $0.0934^{* * *}$ & $0.157^{* * *}$ & $0.0825^{* * *}$ & $0.154^{* * *}$ \\
\hline & $(0.0636)$ & $(0.0707)$ & $(0.0174)$ & $(0.0304)$ & $(0.0209)$ & $(0.0337)$ \\
\hline \multirow[t]{2}{*}{ Observations } & 855 & 855 & 1074 & 1074 & 1074 & 1074 \\
\hline & $\begin{array}{l}\text { standard } \\
<0.01, \\
\text { ed regress }\end{array}$ & $\begin{array}{l}\text { ors in pas } \\
<0.05, * \\
;(2) \text { Fixe }\end{array}$ & $\begin{array}{l}\text { atheses } \\
0.1 \\
\text { Effects }\end{array}$ & & & \\
\hline
\end{tabular}

Using average years of schooling, percentage of poor people, longevity HDI, inequality (Theil Index), children mortality, house infrastructure (telephone and electricity), percentage of woman, mayor party, mayor vote share on the last election, number of electors (as deviation from the threshold), state/municipality fixed effects, electors age composition (young and elderly), political engagement as controls 
Table 53: Discontinuity - Electronic voting impact on PFL Votes party code votes (over total party code votes)

\begin{tabular}{|c|c|c|c|c|}
\hline \multirow{2}{*}{$\begin{array}{l}\text { Dep. Var.: PFL Party Code Vote Share } \\
\text { Regressions }\end{array}$} & \multicolumn{2}{|c|}{ Federal Deputy } & \multicolumn{2}{|c|}{ State Deputy } \\
\hline & (1) & (2) & (1) & (2) \\
\hline Electronic Voting (EV) & $\begin{array}{c}-0.00368 \\
(0.0114)\end{array}$ & & $\begin{array}{c}-0.00851 \\
(0.0121)\end{array}$ & \\
\hline Year $=1998$ & $\begin{array}{c}0.0424^{* * *} * \\
(0.0053)\end{array}$ & $\begin{array}{c}0.0377^{* * *} \\
(0.0079)\end{array}$ & $\begin{array}{c}0.0364^{* * *} \\
(0.0059)\end{array}$ & $\begin{array}{c}0.0302 * * * \\
(0.0081)\end{array}$ \\
\hline EV * Year $=1998[\mathrm{EV}(98)]$ & $\begin{array}{c}-0.00753 \\
(0.0128)\end{array}$ & $\begin{array}{c}-0.00151 \\
(0.0125)\end{array}$ & $\begin{array}{c}0.00889 \\
(0.0124)\end{array}$ & $\begin{array}{c}0.0177 \\
(0.0141)\end{array}$ \\
\hline Poor People (\%) & $\begin{array}{c}-0.0455^{* * *} \\
(0.0105)\end{array}$ & & $\begin{array}{c}-0.0468^{* * *} \\
(0.0131)\end{array}$ & \\
\hline EV $(98) *$ Poor People (\%) & $\begin{array}{c}-0.0661^{* * *} \\
(0.0236)\end{array}$ & $\begin{array}{c}-0.0897^{* * *} \\
(0.0210)\end{array}$ & $\begin{array}{c}-0.0650^{* * *} \\
(0.0239)\end{array}$ & $\begin{array}{c}-0.0878^{* * *} \\
(0.0245)\end{array}$ \\
\hline EV*Poor People (\%) & $\begin{array}{c}0.0232 \\
(0.0154)\end{array}$ & & $\begin{array}{l}0.0303 \\
(0.0184)\end{array}$ & \\
\hline Year $=1998^{*}$ Poor People $(\%)$ & $\begin{array}{c}0.0527^{* * *} * \\
(0.0132)\end{array}$ & $\begin{array}{c}0.0562^{* * *} \\
(0.0126)\end{array}$ & $\begin{array}{c}0.0495^{* * *} \\
(0.0145)\end{array}$ & $\begin{array}{c}0.0538^{* * * *} \\
(0.0139)\end{array}$ \\
\hline EV $(98)^{*}$ Years of study & $\begin{array}{c}-0.0182 \\
(0.0220)\end{array}$ & $\begin{array}{c}-0.0383^{*} \\
(0.0199)\end{array}$ & $\begin{array}{c}-0.0478^{* *} \\
(0.0240)\end{array}$ & $\begin{array}{c}-0.0682^{* * *} \\
(0.0226)\end{array}$ \\
\hline Mayor $(\mathrm{PFL}=1)$ & $\begin{array}{c}0.0336^{* * *} \\
(0.0127)\end{array}$ & $\begin{array}{c}0.0174 \\
(0.0178)\end{array}$ & $\begin{array}{c}0.0457^{* * *} \\
(0.0148)\end{array}$ & $\begin{array}{c}0.0348^{*} \\
(0.0196)\end{array}$ \\
\hline Year $=1998^{*}$ Mayor $(\mathrm{PFL}=1)$ & $\begin{array}{c}0.0115 \\
(0.0154)\end{array}$ & $\begin{array}{c}-0.00697 \\
(0.0223)\end{array}$ & $\begin{array}{c}0.0128 \\
(0.0169)\end{array}$ & $\begin{array}{c}-0.0101 \\
(0.0236)\end{array}$ \\
\hline $\mathrm{EV}^{*}$ Mayor $(\mathrm{PFL}=1)$ & $\begin{array}{c}-0.0517^{* * *} \\
(0.0185)\end{array}$ & $\begin{array}{l}0.0305 \\
(0.0364)\end{array}$ & $\begin{array}{c}-0.0553^{* * *} \\
(0.0191)\end{array}$ & $\begin{array}{c}0.0265 \\
(0.0343)\end{array}$ \\
\hline $\mathrm{EV}(98) *$ Mayor $(\mathrm{PFL}=1)$ & $\begin{array}{c}0.0109 \\
(0.0278)\end{array}$ & $\begin{array}{c}-0.0237 \\
(0.0446)\end{array}$ & $\begin{array}{c}0.0328 \\
(0.0335)\end{array}$ & $\begin{array}{c}-0.0227 \\
(0.0436)\end{array}$ \\
\hline Constant & $\begin{array}{c}0.135 * * * \\
(0.0223)\end{array}$ & $\begin{array}{c}0.0715^{* * *} \\
(0.0236)\end{array}$ & $\begin{array}{c}0.100^{* * *} \\
(0.0193)\end{array}$ & $\begin{array}{c}0.0831^{* * *} \\
(0.0232)\end{array}$ \\
\hline $\begin{array}{l}\text { Robust stand } \\
* * * \mathrm{p}<0.01 \\
\text { (1) Pooled reg }\end{array}$ & $\begin{array}{l}1074 \\
\text { rrors in } \mathrm{p} \\
\mathrm{p}<0.05, \\
\text { on: }(2) \mathrm{Fi}\end{array}$ & $\begin{array}{r}1074 \\
\text { ntheses } \\
<0.1 \\
\text { Effects }\end{array}$ & 1074 & 1074 \\
\hline
\end{tabular}

Using average years of schooling, percentage of poor people, longevity HDI, inequality (Theil Index), children mortality, house infrastructure (telephone and electricity), percentage of woman, mayor party, mayor vote share on the last election, number of electors (as deviation from the threshold), state/municipality fixed effects,electors age composition (young and elderly), political engagement as controls 
Table 54: Discontinuity - Electronic voting impact on Votes for the Mayor Party

\begin{tabular}{|c|c|c|c|c|c|c|c|c|}
\hline Dep. Var.: Mayor Party Code V. S. & \multicolumn{2}{|c|}{ President } & \multicolumn{2}{|c|}{ Governor } & \multicolumn{2}{|c|}{ Federal Deputy } & \multicolumn{2}{|c|}{ State Deputy } \\
\hline Regressions & (1) & (2) & (1) & 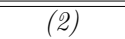 & (1) & (2) & (1) & (2) \\
\hline Electronic Voting (EV) & $\begin{array}{c}0.0231 \\
(0.0196)\end{array}$ & & $\begin{array}{c}0.0796^{*} \\
(0.0420)\end{array}$ & & $\begin{array}{c}0.00369 \\
(0.0325)\end{array}$ & & $\begin{array}{c}-0.0102 \\
(0.0377)\end{array}$ & \\
\hline Year $=1998$ & $\begin{array}{c}-0.106^{* * *} \\
(0.0217)\end{array}$ & $\begin{array}{c}-0.131^{* * *} \\
(0.0337)\end{array}$ & $\begin{array}{c}0.0545^{* *} \\
(0.0224)\end{array}$ & $\begin{array}{c}0.142^{* * *} \\
(0.0435)\end{array}$ & $\begin{array}{c}-0.00467 \\
(0.0131)\end{array}$ & $\begin{array}{c}-0.0268 \\
(0.0195)\end{array}$ & $\begin{array}{c}-0.0409^{* * *} \\
(0.0151)\end{array}$ & $\begin{array}{c}-0.0463^{* *} \\
(0.0232)\end{array}$ \\
\hline EV * Year $=1998[\mathrm{EV}(98)]$ & $\begin{array}{l}0.139 \\
(0.0966)\end{array}$ & $\begin{array}{c}0.337^{* * *} \\
(0.1190)\end{array}$ & $\begin{array}{c}0.0883 \\
(0.0826)\end{array}$ & $\begin{array}{c}0.332^{* *} \\
(0.1400)\end{array}$ & $\begin{array}{l}0.087 \\
(0.0687)\end{array}$ & $\begin{array}{c}0.126^{*} \\
(0.0685)\end{array}$ & $\begin{array}{c}0.112^{*} \\
(0.0627)\end{array}$ & $\begin{array}{c}0.209^{* * *} \\
(0.0806)\end{array}$ \\
\hline Poor People (\%) & $\begin{array}{c}0.0174 \\
(0.0202)\end{array}$ & & $\begin{array}{c}-0.0696 \\
(0.0424)\end{array}$ & & $\begin{array}{c}-0.0737^{* *} \\
(0.0321)\end{array}$ & & $\begin{array}{c}-0.0968^{* * *} \\
(0.0353)\end{array}$ & \\
\hline EV $(98) *$ Poor People $(\%)$ & $\begin{array}{r}-0.072 \\
(0.0839)\end{array}$ & $\begin{array}{c}0.202^{* *} \\
(0.0958)\end{array}$ & $\begin{array}{c}-0.0673 \\
(0.0855)\end{array}$ & $\begin{array}{c}0.0999 \\
(0.1200)\end{array}$ & $\begin{array}{c}-0.0343 \\
(0.0553)\end{array}$ & $\begin{array}{c}-0.0712 \\
(0.0542)\end{array}$ & $\begin{array}{c}-0.257^{* * *} \\
(0.0783)\end{array}$ & $\begin{array}{c}-0.334^{* * *} \\
(0.0741)\end{array}$ \\
\hline Years of study & $\begin{array}{c}-0.0312^{*} \\
(0.0162)\end{array}$ & & $\begin{array}{c}-0.0702^{*} \\
(0.0374)\end{array}$ & & $\begin{array}{c}-0.0207 \\
(0.0292)\end{array}$ & & $\begin{array}{c}-0.0850 * * * \\
(0.0312)\end{array}$ & \\
\hline EV*Poor People (\%) & $\begin{array}{c}0.0253 \\
(0.0271)\end{array}$ & & $\begin{array}{r}0.0447 \\
(0.0609)\end{array}$ & & $\begin{array}{c}0.0315 \\
(0.0449)\end{array}$ & & $\begin{array}{c}0.153^{* *} \\
(0.0663)\end{array}$ & \\
\hline Year $=1998 *$ Poor People $(\%)$ & $\begin{array}{c}-0.0676^{*} \\
(0.0357)\end{array}$ & $\begin{array}{c}-0.126^{*} \\
(0.0695)\end{array}$ & $\begin{array}{c}0.0757^{*} \\
(0.0450)\end{array}$ & $\begin{array}{l}0.066 \\
(0.0675)\end{array}$ & $\begin{array}{c}-0.00614 \\
(0.0292)\end{array}$ & $\begin{array}{c}0.00818 \\
(0.0288)\end{array}$ & $\begin{array}{c}0.0837^{* *} \\
(0.0364)\end{array}$ & $\begin{array}{c}0.0986^{* * *} \\
(0.0367)\end{array}$ \\
\hline $\mathrm{EV}(98)^{*}$ Mayor $(\mathrm{PT}=1)$ & $\begin{array}{c}-0.0915 \\
(0.1350)\end{array}$ & $\begin{array}{c}-0.488^{* * *} \\
(0.1720)\end{array}$ & $\begin{array}{c}-0.0434 \\
(0.0853)\end{array}$ & $\begin{array}{c}-0.109 \\
(0.1650)\end{array}$ & $\begin{array}{c}-0.0603 \\
(0.0705)\end{array}$ & $\begin{array}{l}-0.159 \\
(0.1180)\end{array}$ & $\begin{array}{c}-0.0866 \\
(0.0822)\end{array}$ & $\begin{array}{c}-0.445^{* * *} \\
(0.1620)\end{array}$ \\
\hline $\mathrm{EV}(98) *$ Mayor $(\mathrm{PSDB}=1)$ & $\begin{array}{l}-0.121 \\
(0.1060)\end{array}$ & $\begin{array}{c}-0.436^{* * *} \\
(0.1260)\end{array}$ & $\begin{array}{c}-0.168^{* *} \\
(0.0769)\end{array}$ & $\begin{array}{c}-0.418^{* * *} \\
(0.1180)\end{array}$ & $\begin{array}{c}-0.103 \\
(0.0716)\end{array}$ & $\begin{array}{r}-0.116 \\
(0.0766)\end{array}$ & $\begin{array}{c}-0.163^{* *} \\
(0.0667)\end{array}$ & $\begin{array}{c}-0.202^{* *} \\
(0.0885)\end{array}$ \\
\hline Constant & $\begin{array}{c}0.00219 \\
(0.0463)\end{array}$ & $\begin{array}{c}-0.200^{*} \\
(0.1210)\end{array}$ & $\begin{array}{c}0.485^{* * *} \\
(0.0776)\end{array}$ & $\begin{array}{c}0.0989 \\
(0.1650)\end{array}$ & $\begin{array}{c}0.0651 \\
(0.0636)\end{array}$ & $\begin{array}{c}0.108^{*} \\
(0.0624)\end{array}$ & $\begin{array}{r}-0.074 \\
(0.0511) \\
\end{array}$ & $\begin{array}{c}0.126^{*} \\
(0.0743)\end{array}$ \\
\hline Observations & $\begin{array}{l}444 \\
\text { Rob }\end{array}$ & $\begin{array}{c}\quad 444 \\
\text { standar } \\
0<0.01,\end{array}$ & $\begin{array}{c}558 \\
\text { rors in } \\
p<0.05\end{array}$ & $\begin{array}{c}\quad 558 \\
\text { entheses } \\
<0.1\end{array}$ & 1047 & 1047 & 1047 & 1047 \\
\hline
\end{tabular}

Using average years of schooling, percentage of poor people, longevity HDI, inequality (Theil Index), children mortality, house infrastructure (telephone and electricity), percentage of woman, mayor party, mayor vote share on the last election, number of electors (as deviation from the threshold), state/municipality fixed effects,electors age composition (young and elderly), political engagement as controls 
Table 55: Discontinuity - Electronic voting impact on Party Code Votes from the Mayor Party (over total party code votes)

\begin{tabular}{|c|c|c|c|c|}
\hline Dep. Var.: Mayor Party Code V. S. & \multicolumn{2}{|c|}{ Federal Deputy } & \multicolumn{2}{|c|}{ State Deputy } \\
\hline Regressions & $\overline{(1)}$ & $\overline{(2)}$ & (1) & (2) \\
\hline Electronic Voting (EV) & $\begin{array}{c}-0.000194 \\
(0.0156)\end{array}$ & & $\begin{array}{c}-0.000617 \\
(0.0178)\end{array}$ & \\
\hline Year $=1998$ & $\begin{array}{c}0.0159 * \\
(0.0082)\end{array}$ & $\begin{array}{c}0.0135 \\
(0.0136)\end{array}$ & $\begin{array}{c}0.0173^{*} \\
(0.0088)\end{array}$ & $\begin{array}{c}0.0077 \\
(0.0168)\end{array}$ \\
\hline EV $*$ Year $=1998[\mathrm{EV}(98)]$ & $\begin{array}{c}0.0135 \\
(0.0263)\end{array}$ & $\begin{array}{c}0.00404 \\
(0.0442)\end{array}$ & $\begin{array}{c}0.0496 \\
(0.0366)\end{array}$ & $\begin{array}{c}0.0452 \\
(0.0517)\end{array}$ \\
\hline Poor People (\%) & $\begin{array}{c}-0.00674 \\
(0.0179)\end{array}$ & & $\begin{array}{c}0.00313 \\
(0.0189)\end{array}$ & \\
\hline EV $(98) *$ Poor People (\%) & $\begin{array}{c}-0.0559^{*} \\
(0.0316)\end{array}$ & $\begin{array}{c}-0.0778^{* *} \\
(0.0310)\end{array}$ & $\begin{array}{c}-0.0364 \\
(0.0393)\end{array}$ & $\begin{array}{c}-0.0519 \\
(0.0368)\end{array}$ \\
\hline Years of study & $\begin{array}{c}-0.0483^{* * *} \\
(0.0152)\end{array}$ & & $\begin{array}{c}-0.0417^{* * *} \\
(0.0152)\end{array}$ & \\
\hline EV*Poor People $(\%)$ & $\begin{array}{c}0.00993 \\
(0.0238)\end{array}$ & & $\begin{array}{c}0.00388 \\
(0.0289)\end{array}$ & \\
\hline Year $=1998 *$ Poor People $(\%)$ & $\begin{array}{c}0.0192 \\
(0.0187)\end{array}$ & $\begin{array}{c}0.0274 \\
(0.0194)\end{array}$ & $\begin{array}{c}-0.00191 \\
(0.0195)\end{array}$ & $\begin{array}{c}0.00932 \\
(0.0195)\end{array}$ \\
\hline $\mathrm{EV}(98) *$ Mayor $(\mathrm{PT}=1)$ & $\begin{array}{c}-0.186^{* * *} \\
(0.0515)\end{array}$ & $\begin{array}{c}-0.172^{* *} \\
(0.0781)\end{array}$ & $\begin{array}{c}-0.222^{* * *} \\
(0.0631)\end{array}$ & $\begin{array}{c}-0.188^{* *} \\
(0.0832)\end{array}$ \\
\hline $\mathrm{EV}(98) *$ Mayor $(\mathrm{PMDB}=1)$ & $\begin{array}{c}-0.0594^{* *} \\
(0.0256)\end{array}$ & $\begin{array}{c}-0.0811 * \\
(0.0490)\end{array}$ & $\begin{array}{c}-0.0737^{* *} \\
(0.0355)\end{array}$ & $\begin{array}{c}-0.0980^{*} \\
(0.0546)\end{array}$ \\
\hline $\mathrm{EV}(98) *$ Mayor $(\mathrm{PSDB}=1)$ & $\begin{array}{c}-0.0675^{* *} \\
(0.0299)\end{array}$ & $\begin{array}{c}-0.0425 \\
(0.0458)\end{array}$ & $\begin{array}{c}-0.0243 \\
(0.0393)\end{array}$ & $\begin{array}{c}-0.0169 \\
(0.0532)\end{array}$ \\
\hline Constant & $\begin{array}{c}0.00476 \\
(0.0463)\end{array}$ & $\begin{array}{c}0.0535 \\
(0.0433)\end{array}$ & $\begin{array}{c}-0.00592 \\
(0.0391)\end{array}$ & $\begin{array}{c}0.0995^{*} \\
(0.0542)\end{array}$ \\
\hline Observations & 1016 & 1016 & 1009 & 1009 \\
\hline
\end{tabular}

Robust standard errors in parentheses

$$
* * * \mathrm{p}<0.01, * * \mathrm{p}<0.05, * \mathrm{p}<0.1
$$

(1) Pooled regression; (2) Fixed Effects Using average years of schooling, percentage of poor people, longevity HDI, inequality (Theil Index), children mortality, house
infrastructure (telephone and electricity), percentage of woman, mayor party, mayor vote share on the last election, number of electors (as deviation from the threshold), state/municipality fixed effects,electors age composition (young and elderly), political 
Table 56: Discontinuity - Electronic voting impact on the probability of choosing the same party for legislative and president offices

\begin{tabular}{|c|c|c|c|c|}
\hline Dep. Var.: Prob. of voting on & \multicolumn{2}{|c|}{ PT } & \multicolumn{2}{|c|}{ PSDB } \\
\hline Regressions & (1) & (2) & (1) & (2) \\
\hline Electronic Voting (EV) & $\begin{array}{c}0.00332^{* *} \\
(0.0015)\end{array}$ & & $\begin{array}{c}0.00257 \\
(0.0063)\end{array}$ & \\
\hline Year $=1998$ & $\begin{array}{c}0.00106^{*} \\
(0.0006)\end{array}$ & $\begin{array}{c}0.00127^{*} \\
(0.0007)\end{array}$ & $\begin{array}{c}0.00119 \\
(0.0028)\end{array}$ & $\begin{array}{c}0.00462 \\
(0.0032)\end{array}$ \\
\hline EV * Year $=1998[\mathrm{EV}(98)]$ & $\begin{array}{c}0.000296 \\
(0.0012)\end{array}$ & $\begin{array}{c}0.00220^{* *} \\
(0.0010)\end{array}$ & $\begin{array}{l}0.00444 \\
(0.0076)\end{array}$ & $\begin{array}{l}-0.0002 \\
(0.0082)\end{array}$ \\
\hline EV $(98) *$ Poor People (\%) & $\begin{array}{c}0.003 \\
(0.0026)\end{array}$ & $\begin{array}{l}0.00344 \\
(0.0024)\end{array}$ & $\begin{array}{l}-0.0177 \\
(0.0130)\end{array}$ & $\begin{array}{c}-0.0260 * * \\
(0.0128)\end{array}$ \\
\hline EV(98)*Years of study & $\begin{array}{l}0.00398 \\
(0.0026)\end{array}$ & $\begin{array}{l}0.00116 \\
(0.0023)\end{array}$ & $\begin{array}{c}-0.0213^{* *} \\
(0.0097)\end{array}$ & $\begin{array}{c}-0.0248^{* *} \\
(0.0101)\end{array}$ \\
\hline Mayor & $\begin{array}{c}0.0119 \\
(0.0102)\end{array}$ & $\begin{array}{l}-0.0122 \\
(0.0092)\end{array}$ & $\begin{array}{c}0.0419^{* *} \\
(0.0188)\end{array}$ & $\begin{array}{l}0.0334^{*} \\
(0.0188)\end{array}$ \\
\hline Year $=1998^{*}$ Mayor & $\begin{array}{c}-0.00476 \\
(0.0104)\end{array}$ & $\begin{array}{r}-0.00406 \\
(0.0153)\end{array}$ & $\begin{array}{c}-0.0341^{* *} \\
(0.0168)\end{array}$ & $\begin{array}{c}-0.0408^{* *} \\
(0.0175)\end{array}$ \\
\hline EV*Mayor & $\begin{array}{c}-0.00897 \\
(0.0111)\end{array}$ & $\begin{array}{l}0.00177 \\
(0.0103)\end{array}$ & $\begin{array}{c}-0.018 \\
(0.0239)\end{array}$ & $\begin{array}{l}0.00735 \\
(0.0240)\end{array}$ \\
\hline $\mathrm{EV}(98) *$ Mayor & $\begin{array}{r}-0.00287 \\
(0.0122)\end{array}$ & $\begin{array}{l}0.00212 \\
(0.0165)\end{array}$ & $\begin{array}{c}-0.00118 \\
(0.0249)\end{array}$ & $\begin{array}{c}0.00516 \\
(0.0238)\end{array}$ \\
\hline Constant & $\begin{array}{r}-0.00128 \\
(0.0019)\end{array}$ & $\begin{array}{c}-0.000315 \\
(0.0018)\end{array}$ & $\begin{array}{c}-0.0155^{*} \\
(0.0080)\end{array}$ & $\begin{array}{c}0.00937 \\
(0.0099)\end{array}$ \\
\hline Observations & $\begin{array}{l}1074 \\
\text { d error } \\
* * \quad p<\end{array}$ & $\begin{array}{l}1074 \\
\text { arenthe } \\
* \mathrm{p}<0.1\end{array}$ & 1074 & 1074 \\
\hline
\end{tabular}

(1) Pooled regression; (2) Fixed Effects

Using average years of schooling, percentage of poor people, longevity HDI, inequality (Theil Index), children mortality, house infrastructure (telephone and electricity), percentage of woman, mayor party,mayor vote share on the last election, number of electors (as deviation from the threshold), state/municipality fixed effects,electors age composition (young and elderly), political engagement as controls 
Table 57: Discontinuity - Electronic voting impact on the probability of choosing the same party for legislative offices (party code votes)

\begin{tabular}{|c|c|c|c|c|c|c|}
\hline \multirow{2}{*}{$\begin{array}{l}\text { Dep. Var.: Prob. of voting on } \\
\text { Regressions }\end{array}$} & \multicolumn{2}{|c|}{$\mathrm{PT}$} & \multicolumn{2}{|c|}{ PSDB } & \multicolumn{2}{|c|}{ PMDB } \\
\hline & (1) & (2) & (1) & (2) & (1) & (2) \\
\hline \multirow[t]{2}{*}{ Electronic Voting (EV) } & 0.0294 & & -0.0142 & & $0.0153^{* *}$ & \\
\hline & $(0.0243)$ & & $(0.0117)$ & & $(0.0073)$ & \\
\hline \multirow[t]{2}{*}{ Year $=1998$} & $-0.146^{* * *}$ & $-0.135^{* * *}$ & $0.0510^{* * *}$ & $0.0581^{* * *}$ & $0.0245^{* * *}$ & $0.0212^{* *}$ \\
\hline & $(0.0089)$ & $(0.0142)$ & $(0.0073)$ & $(0.0103)$ & $(0.0066)$ & $(0.0104)$ \\
\hline \multirow{2}{*}{ EV $*$ Year $=1998[$ EV $(98)]$} & $-0.0670^{* * *}$ & $-0.0637^{* *} *$ & -0.00321 & -0.00742 & $-0.0292^{* * *}$ & $-0.0334^{* * *}$ \\
\hline & $(0.0249)$ & $(0.0263)$ & $(0.0119)$ & $(0.0141)$ & $(0.0070)$ & $(0.0084)$ \\
\hline \multirow[t]{2}{*}{ EV $(98) *$ Poor People $(\%)$} & 0.0101 & 0.043 & 0.0139 & 0.00248 & 0.00614 & 0.0143 \\
\hline & $(0.0423)$ & $(0.0425)$ & $(0.0203)$ & $(0.0189)$ & $(0.0121)$ & $(0.0127)$ \\
\hline \multirow[t]{2}{*}{ EV $(98)^{*}$ Years of study } & 0.0233 & 0.035 & 0.00353 & -0.00265 & 0.004 & 0.0034 \\
\hline & $(0.0352)$ & $(0.0370)$ & $(0.0181)$ & $(0.0190)$ & $(0.0131)$ & $(0.0129)$ \\
\hline \multirow[t]{2}{*}{ Mayor } & -0.0219 & $-0.0585^{* *}$ & $0.0155^{*}$ & 0.0169 & $0.0167^{* * *}$ & $0.0239^{*}$ \\
\hline & $(0.0174)$ & $(0.0276)$ & $(0.0094)$ & $(0.0110)$ & $(0.0063)$ & $(0.0137)$ \\
\hline \multirow[t]{2}{*}{ Year $=1998^{*}$ Mayor } & 0.0049 & 0.0105 & 0.00321 & -0.0222 & -0.0034 & -0.0189 \\
\hline & $(0.0150)$ & $(0.0242)$ & $(0.0151)$ & $(0.0214)$ & $(0.0091)$ & $(0.0165)$ \\
\hline \multirow[t]{2}{*}{$\mathrm{EV}^{*}$ Mayor } & -0.00969 & -0.0172 & 0.00669 & -0.00448 & -0.00194 & -0.0181 \\
\hline & $(0.0287)$ & $(0.0350)$ & $(0.0146)$ & $(0.0173)$ & $(0.0095)$ & $(0.0124)$ \\
\hline \multirow[t]{2}{*}{ EV $(98)^{*}$ Mayor } & 0.0316 & 0.0728 & -0.00705 & 0.0198 & -0.0156 & 0.0151 \\
\hline & $(0.0340)$ & $(0.0547)$ & $(0.0189)$ & $(0.0280)$ & $(0.0153)$ & $(0.0186)$ \\
\hline \multirow[t]{2}{*}{ Constant } & $0.243^{* * *}$ & $0.187^{* * *}$ & $-0.0297^{* *}$ & 0.0342 & -0.00513 & 0.0287 \\
\hline & $(0.0618)$ & $(0.0410)$ & $(0.0134)$ & $(0.0293)$ & $(0.0096)$ & $(0.0221)$ \\
\hline Observations & 1074 & 1074 & 1074 & 1074 & 1074 & 1074 \\
\hline
\end{tabular}

(1) Pooled regression; (2) Fixed Effects

Using average years of schooling, percentage of poor people, longevity HDI, inequality (Theil Index), children mortality, house infrastructure (telephone and electricity), percentage of woman, mayor party, mayor vote share on the last election, number of electors (as deviation from the threshold), state/municipality fixed effects, electors age composition (young and elderly), political engagement as controls 
Table 58: Discontinuity - Electronic voting impact on the odds of voting for PSDB deputy over PSDB president

\begin{tabular}{|c|c|c|c|c|}
\hline Dep. Var.: Odds of voting for: & Federa & Deputy & State & Deputy \\
\hline Regressions & 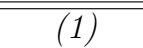 & 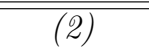 & (1) & 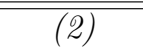 \\
\hline Electronic Voting (EV) & $\begin{array}{c}-0.0387 \\
(0.0463)\end{array}$ & & $\begin{array}{r}0.0146 \\
(0.0450)\end{array}$ & \\
\hline Year $=1998$ & $\begin{array}{c}0.154^{* * *} \\
(0.0244)\end{array}$ & $\begin{array}{c}0.145^{* * *} \\
(0.0303)\end{array}$ & $\begin{array}{c}0.115^{* * *} \\
(0.0224)\end{array}$ & $\begin{array}{c}0.122^{* * *} \\
(0.0307)\end{array}$ \\
\hline EV * Year $=1998[\mathrm{EV}(98)]$ & $\begin{array}{c}-0.0238 \\
(0.0505)\end{array}$ & $\begin{array}{c}-0.0122 \\
(0.0529)\end{array}$ & $\begin{array}{c}-0.00248 \\
(0.0442)\end{array}$ & $\begin{array}{c}-0.0328 \\
(0.0436)\end{array}$ \\
\hline Poor People (\%) & $\begin{array}{c}-0.0297 \\
(0.0384)\end{array}$ & & $\begin{array}{c}0.0393 \\
(0.0361)\end{array}$ & \\
\hline EV $(98)^{*}$ Poor People $(\%)$ & $\begin{array}{c}0.00106 \\
(0.0915)\end{array}$ & $\begin{array}{c}0.07 \\
(0.0949)\end{array}$ & $\begin{array}{c}-0.124 \\
(0.0869)\end{array}$ & $\begin{array}{l}-0.12 \\
(0.0847)\end{array}$ \\
\hline Years of study & $\begin{array}{c}0.0598^{*} \\
(0.0347)\end{array}$ & & $\begin{array}{c}0.0704^{*} \\
(0.0359)\end{array}$ & \\
\hline EV*Poor People (\%) & $\begin{array}{c}-0.0322 \\
(0.0620)\end{array}$ & & $\begin{array}{c}0.00732 \\
(0.0770)\end{array}$ & \\
\hline Year $=1998^{*}$ Poor People $(\%)$ & $\begin{array}{c}0.121^{* *} \\
(0.0507)\end{array}$ & $\begin{array}{c}0.0968^{*} \\
(0.0508)\end{array}$ & $\begin{array}{l}0.032 \\
(0.0440)\end{array}$ & $\begin{array}{c}0.00739 \\
(0.0436)\end{array}$ \\
\hline Mayor $(\mathrm{PSDB}=1)$ & $\begin{array}{c}-0.0338 \\
(0.0564)\end{array}$ & $\begin{array}{c}-0.223^{*} \\
(0.1160)\end{array}$ & $\begin{array}{l}0.109 \\
(0.0779)\end{array}$ & $\begin{array}{c}-0.0127 \\
(0.1100)\end{array}$ \\
\hline Year $=1998^{*}$ Mayor $(\mathrm{PSDB}=1)$ & $\begin{array}{l}0.141^{*} \\
(0.0734)\end{array}$ & $\begin{array}{c}0.340^{* * *} \\
(0.1170)\end{array}$ & $\begin{array}{c}-0.00209 \\
(0.0881)\end{array}$ & $\begin{array}{c}0.0616 \\
(0.1090)\end{array}$ \\
\hline $\mathrm{EV}^{*}$ Mayor $(\mathrm{PSDB}=1)$ & $\begin{array}{c}0.0542 \\
(0.1110)\end{array}$ & $\begin{array}{l}0.123 \\
(0.1660)\end{array}$ & $\begin{array}{r}-0.055 \\
(0.1370)\end{array}$ & $\begin{array}{c}-0.0222 \\
(0.1510)\end{array}$ \\
\hline $\mathrm{EV}(98) *$ Mayor $(\mathrm{PSDB}=1)$ & $\begin{array}{c}-0.249^{*} \\
(0.1420)\end{array}$ & $\begin{array}{c}-0.389 * * \\
(0.1860)\end{array}$ & $\begin{array}{r}-0.111 \\
(0.1580)\end{array}$ & $\begin{array}{c}-0.0642 \\
(0.1460)\end{array}$ \\
\hline Constant & $\begin{array}{c}0.138 * * \\
(0.0547)\end{array}$ & $\begin{array}{c}0.318^{* * *} \\
(0.0826)\end{array}$ & $\begin{array}{c}0.0102 \\
(0.0702)\end{array}$ & $\begin{array}{c}0.196^{* * *} \\
(0.0729)\end{array}$ \\
\hline $\begin{array}{l}\text { Robust stanc } \\
* * * \mathrm{p}<0.0\end{array}$ & $\begin{array}{c}1074 \\
\text { errors } \\
<* \mathrm{p}<0 \text {. }\end{array}$ & $\begin{array}{l}1074 \\
\text { arenthe } \\
* \mathrm{p}<0.1\end{array}$ & 1074 & 1074 \\
\hline
\end{tabular}

Using average years of schooling, percentage of poor people, longevity HDI, inequality (Theil Index), children mortality, house infrastructure (telephone and electricity), percentage of woman, mayor party, mayor vote share on the last election, number of electors (as deviation from the threshold), state/municipality fixed effects, electors age composition (young and elderly), political engagement as controls 
Table 59: Discontinuity - Electronic voting impact on the odds of voting for PSDB deputy (Party Code) over PSDB president

\begin{tabular}{|c|c|c|c|c|}
\hline Dep. Var.: Odds of voting for: & Federal & Deputy & State $]$ & Deputy \\
\hline Regressions & (1) & (2) & (1) & (2) \\
\hline Electronic Voting (EV) & $\begin{array}{c}-0.00321 \\
(0.0285)\end{array}$ & & $\begin{array}{c}0.0156 \\
(0.0277)\end{array}$ & \\
\hline Year $=1998$ & $\begin{array}{c}0.243^{* * *} \\
(0.0165)\end{array}$ & $\begin{array}{c}0.234^{* * *} \\
(0.0234)\end{array}$ & $\begin{array}{c}0.236^{* * *} \\
(0.0167)\end{array}$ & $\begin{array}{c}0.226^{* * *} \\
(0.0248)\end{array}$ \\
\hline EV * Year $=1998[\mathrm{EV}(98)]$ & $\begin{array}{c}-0.0584^{* *} \\
(0.0282)\end{array}$ & $\begin{array}{c}-0.0662^{* *} \\
(0.0309)\end{array}$ & $\begin{array}{c}0.0500^{*} \\
(0.0280)\end{array}$ & $\begin{array}{c}0.0493 \\
(0.0324)\end{array}$ \\
\hline Poor People $(\%)$ & $\begin{array}{c}0.0209 \\
(0.0230)\end{array}$ & & $\begin{array}{c}0.00644 \\
(0.0206)\end{array}$ & \\
\hline EV $(98) *$ Poor People $(\%)$ & $\begin{array}{c}0.0159 \\
(0.0594)\end{array}$ & $\begin{array}{c}0.0425 \\
(0.0599)\end{array}$ & $\begin{array}{c}0.129 * * \\
(0.0636)\end{array}$ & $\begin{array}{c}0.153^{* *} \\
(0.0666)\end{array}$ \\
\hline Years of study & $\begin{array}{c}0.0175 \\
(0.0226)\end{array}$ & & $\begin{array}{c}0.0532^{* *} \\
(0.0211)\end{array}$ & \\
\hline EV*Poor People (\%) & $\begin{array}{c}-0.0556 \\
(0.0417)\end{array}$ & & $\begin{array}{c}-0.0727^{*} \\
(0.0427)\end{array}$ & \\
\hline Year $=1998^{*}$ Poor People $(\%)$ & $\begin{array}{c}0.0743^{*} \\
(0.0395)\end{array}$ & $\begin{array}{c}0.0586 \\
(0.0391)\end{array}$ & $\begin{array}{c}0.0915^{* *} \\
(0.0374)\end{array}$ & $\begin{array}{c}0.0944^{* *} \\
(0.0383)\end{array}$ \\
\hline Mayor $(\mathrm{PSDB}=1)$ & $\begin{array}{l}-0.043 \\
(0.0455)\end{array}$ & $\begin{array}{c}-0.139 * \\
(0.0764)\end{array}$ & $\begin{array}{c}-0.0212 \\
(0.0371)\end{array}$ & $\begin{array}{c}-0.0987 \\
(0.0676)\end{array}$ \\
\hline Year $=1998^{*}$ Mayor $(\mathrm{PSDB}=1)$ & $\begin{array}{c}0.178^{* * *} \\
(0.0612)\end{array}$ & $\begin{array}{c}0.293^{* * *} \\
(0.0840)\end{array}$ & $\begin{array}{c}0.158^{* * *} \\
(0.0537)\end{array}$ & $\begin{array}{c}0.266^{* * *} \\
(0.0750)\end{array}$ \\
\hline $\mathrm{EV}^{*}$ Mayor $(\mathrm{PSDB}=1)$ & $\begin{array}{c}-0.0633 \\
(0.0642)\end{array}$ & $\begin{array}{c}0.0536 \\
(0.0910)\end{array}$ & $\begin{array}{c}-0.115^{*} \\
(0.0639)\end{array}$ & $\begin{array}{c}-0.0665 \\
(0.0942)\end{array}$ \\
\hline $\mathrm{EV}(98) *$ Mayor $(\mathrm{PSDB}=1)$ & $\begin{array}{c}-0.193^{* *} \\
(0.0870)\end{array}$ & $\begin{array}{c}-0.240^{* *} \\
(0.1030)\end{array}$ & $\begin{array}{c}-0.0722 \\
(0.0892)\end{array}$ & $\begin{array}{c}-0.0923 \\
(0.1070)\end{array}$ \\
\hline Constant & $\begin{array}{c}0.123^{* * *} \\
(0.0450)\end{array}$ & $\begin{array}{c}0.290 * * * \\
(0.0536)\end{array}$ & $\begin{array}{c}0.0318 \\
(0.0414) \\
\end{array}$ & $\begin{array}{c}0.238 * * * \\
(0.0586)\end{array}$ \\
\hline $\begin{array}{l}\text { Robust star } \\
\quad * * * \quad \mathrm{p}<0\end{array}$ & $\begin{array}{c}1074 \\
\text { errors } \\
* \mathrm{p}<0 .\end{array}$ & $\begin{array}{c}1074 \\
\text { arenthes } \\
\mathrm{p}<0.1\end{array}$ & 1074 & 1074 \\
\hline
\end{tabular}

(1) Pooled regression; (2) Fixed Effects

Using average years of schooling, percentage of poor people, longevity HDI, inequality (Theil Index),children mortality, house infrastructure (telephone and electricity), percentage of woman, mayor party, mayor vote share on the last election, number of electors (as deviation from the threshold), state/municipality fixed effects, electors age composition (young and elderly), political engagement as controls 
Table 60: Discontinuity - Electronic voting impact on the odds of voting for PT deputy over PT president

\begin{tabular}{|c|c|c|c|c|}
\hline \multirow{2}{*}{$\begin{array}{l}\text { Dep. Var.: Odds of voting for: } \\
\text { Regressions }\end{array}$} & \multicolumn{2}{|c|}{ Federal Deputy } & \multicolumn{2}{|c|}{ State Deputy } \\
\hline & $\overline{(1)}$ & (2) & $\overline{~(1) ~}$ & (2) \\
\hline \multirow{2}{*}{ Electronic Voting (EV) } & 0.00214 & & 0.0814 & \\
\hline & $(0.0560)$ & & $(0.0555)$ & \\
\hline \multirow[t]{2}{*}{ Year $=1998$} & $-0.0640^{* * *}$ & $-0.0718^{* *}$ & $-0.0474^{* *}$ & -0.0279 \\
\hline & $(0.0203)$ & $(0.0298)$ & $(0.0206)$ & $(0.0239)$ \\
\hline \multirow{2}{*}{$\mathrm{EV} *$ Year $=1998[\mathrm{EV}(98)]$} & $0.0963^{* *}$ & $0.112^{* * *}$ & 0.0264 & $0.0650^{*}$ \\
\hline & $(0.0418)$ & $(0.0384)$ & $(0.0458)$ & $(0.0358)$ \\
\hline \multirow[t]{2}{*}{ Poor People (\%) } & -0.0188 & & 0.0267 & \\
\hline & $(0.0457)$ & & $(0.0531)$ & \\
\hline \multirow{2}{*}{ EV $(98) *$ Poor People $(\%)$} & -0.0858 & -0.0986 & $0.158^{* *}$ & $0.168^{* *}$ \\
\hline & $(0.0823)$ & $(0.0792)$ & $(0.0755)$ & $(0.0840)$ \\
\hline \multirow[t]{2}{*}{ Years of study } & $0.0780^{*}$ & & $0.0942^{* *}$ & \\
\hline & $(0.0431)$ & & $(0.0379)$ & \\
\hline \multirow[t]{2}{*}{$\mathrm{EV}^{*}$ Poor People $(\%)$} & 0.0853 & & -0.0794 & \\
\hline & $(0.0793)$ & & $(0.0861)$ & \\
\hline \multirow{2}{*}{ Year $=1998^{*}$ Poor People $(\%)$} & 0.0126 & 0.0287 & $-0.160^{* * *}$ & $-0.146^{* * *}$ \\
\hline & $(0.0428)$ & $(0.0404)$ & $(0.0483)$ & $(0.0478)$ \\
\hline \multirow[t]{2}{*}{ Mayor $(\mathrm{PT}=1)$} & $0.283^{* * *}$ & -0.0948 & 0.275 & -0.375 \\
\hline & $(0.0921)$ & $(0.1090)$ & $(0.2010)$ & $(0.2300)$ \\
\hline \multirow[t]{2}{*}{ Year $=1998^{*}$ Mayor $(\mathrm{PT}=1)$} & 0.087 & 0.0776 & 0.392 & 0.224 \\
\hline & $(0.1970)$ & $(0.3110)$ & $(0.3120)$ & $(0.3610)$ \\
\hline \multirow[t]{2}{*}{$\mathrm{EV}^{*}$ Mayor $(\mathrm{PT}=1)$} & 0.146 & $0.367^{*}$ & -0.263 & -0.253 \\
\hline & $(0.1380)$ & $(0.2010)$ & $(0.2200)$ & $(0.3800)$ \\
\hline \multirow{2}{*}{$\mathrm{EV}(98)^{*}$ Mayor $(\mathrm{PT}=1)$} & $-0.439^{*}$ & -0.32 & -0.0623 & 0.149 \\
\hline & $(0.2350)$ & $(0.3650)$ & $(0.3440)$ & $(0.4880)$ \\
\hline \multirow[t]{2}{*}{ Constant } & $0.312^{* * *}$ & $0.363^{* * *}$ & $0.120^{* *}$ & $0.216^{* * *}$ \\
\hline & $(0.0664)$ & $(0.0852)$ & $(0.0577)$ & $(0.0642)$ \\
\hline Observations & 1074 & 1074 & 1074 & 1074 \\
\hline
\end{tabular}

(1) Pooled regression; (2) Fixed Effects

Using average years of schooling, percentage of poor people, longevity HDI, inequality (Theil Index),children mortality, house infrastructure (telephone and electricity), percentage of woman, mayor party, mayor vote share on the last election, number of electors (as deviation from the threshold), state/municipality fixed effects, electors age composition (young and elderly), political engagement as controls 
Table 61: Discontinuity - Electronic voting impact on the odds of voting for PT deputy (Party Code) over PT president

\begin{tabular}{|c|c|c|c|c|}
\hline Dep. Var.: Odds of voting for: & Federal & Deputy & State 1 & eputy \\
\hline Regressions & (1) & (2) & (1) & (2) \\
\hline Electronic Voting (EV) & $\begin{array}{c}-0.0622 \\
(0.0921)\end{array}$ & & $\begin{array}{c}-0.0953 \\
(0.1110)\end{array}$ & \\
\hline Year $=1998$ & $\begin{array}{c}-1.083^{* * *} \\
(0.0478)\end{array}$ & $\begin{array}{c}-1.032^{* * *} \\
(0.0665)\end{array}$ & $\begin{array}{c}-1.128^{* * *} \\
(0.0529)\end{array}$ & $\begin{array}{c}-1.119 * * * \\
(0.0740)\end{array}$ \\
\hline EV * Year $=1998[\mathrm{EV}(98)]$ & $\begin{array}{c}-0.0742 \\
(0.0951)\end{array}$ & $\begin{array}{c}-0.0595 \\
(0.1000)\end{array}$ & $\begin{array}{l}-0.163 \\
(0.1130)\end{array}$ & $\begin{array}{l}-0.169 \\
(0.1170)\end{array}$ \\
\hline Poor People (\%) & $\begin{array}{c}-0.0179 \\
(0.1110)\end{array}$ & & $\begin{array}{c}0.0994 \\
(0.1100)\end{array}$ & \\
\hline EV $(98) *$ Poor People (\%) & $\begin{array}{c}0.0859 \\
(0.2160)\end{array}$ & $\begin{array}{c}0.12 \\
(0.2260)\end{array}$ & $\begin{array}{l}0.235 \\
(0.2300)\end{array}$ & $\begin{array}{l}0.246 \\
(0.2480)\end{array}$ \\
\hline Years of study & $\begin{array}{c}0.0942 \\
(0.0973)\end{array}$ & & $\begin{array}{c}0.0792 \\
(0.1030)\end{array}$ & \\
\hline EV*Poor People (\%) & $\begin{array}{c}-0.0418 \\
(0.1790)\end{array}$ & & $\begin{array}{c}-0.0599 \\
(0.1940)\end{array}$ & \\
\hline Year $=1998^{*}$ Poor People $(\%)$ & $\begin{array}{c}-0.0838 \\
(0.1180)\end{array}$ & $\begin{array}{c}-0.0988 \\
(0.1170)\end{array}$ & $\begin{array}{l}-0.162 \\
(0.1140)\end{array}$ & $\begin{array}{r}-0.166 \\
(0.1150)\end{array}$ \\
\hline Mayor $(\mathrm{PT}=1)$ & $\begin{array}{l}-0.248 \\
(0.2450)\end{array}$ & $\begin{array}{l}-0.233 \\
(0.2890)\end{array}$ & $\begin{array}{l}-0.179 \\
(0.3580)\end{array}$ & $\begin{array}{c}0.00535 \\
(0.3570)\end{array}$ \\
\hline Year $=1998^{*}$ Mayor $(\mathrm{PT}=1)$ & $\begin{array}{l}0.166 \\
(0.2990)\end{array}$ & $\begin{array}{l}0.266 \\
(0.3370)\end{array}$ & $\begin{array}{l}0.054 \\
(0.4140)\end{array}$ & $\begin{array}{c}0.07 \\
(0.4410)\end{array}$ \\
\hline $\mathrm{EV}^{*}$ Mayor $(\mathrm{PT}=1)$ & $\begin{array}{r}0.0762 \\
(0.3020)\end{array}$ & $\begin{array}{c}0.0241 \\
(0.3260)\end{array}$ & $\begin{array}{c}-0.0225 \\
(0.4010)\end{array}$ & $\begin{array}{r}-0.423 \\
(0.4000)\end{array}$ \\
\hline $\mathrm{EV}(98)^{*}$ Mayor $(\mathrm{PT}=1)$ & $\begin{array}{l}-0.153 \\
(0.4030)\end{array}$ & $\begin{array}{c}0.0957 \\
(0.4660)\end{array}$ & $\begin{array}{c}0.0413 \\
(0.5040)\end{array}$ & $\begin{array}{l}0.711 \\
(0.5550)\end{array}$ \\
\hline Constant & $\begin{array}{c}1.729 * * * \\
(0.1480)\end{array}$ & $\begin{array}{c}1.842^{* * *} \\
(0.1850) \\
\end{array}$ & $\begin{array}{c}1.626^{* * *} \\
(0.2130) \\
\end{array}$ & $\begin{array}{c}1.981 * * * \\
(0.2140)\end{array}$ \\
\hline $\begin{array}{r}\text { Robust sta } \\
* * * \quad \mathrm{p}<\end{array}$ & $\begin{array}{l}1074 \\
\text { errors } \\
* * \quad \mathrm{p}<0\end{array}$ & $\begin{array}{c}1074 \\
* \mathrm{p}<0.1\end{array}$ & 1074 & 1074 \\
\hline
\end{tabular}

(1) Pooled regression; (2) Fixed Effects

Using average years of schooling, percentage of poor people, longevity HDI, inequality (Theil Index), children mortality, house infrastructure (telephone and electricity), percentage of woman, mayor party,mayor vote share on the last election, number of electors (as deviation from the threshold), state/municipality fixed effects,electors age composition (young and elderly), political engagement as controls 


\section{D.2 Results with municipalities with tight 1996 mayor election margin of victory (5\% or less)}

Table 62: Tight election race - Electronic voting impact on Invalid Votes

\begin{tabular}{|c|c|c|c|c|c|c|c|c|}
\hline Dep. Var.: Invalid & Pres & ident & Gov & rnor & Federal & Deputy & State & Deputy \\
\hline Regressions & 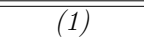 & 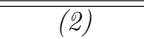 & (1) & 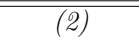 & (1) & 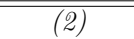 & (1) & 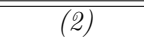 \\
\hline Electronic Voting (EV) & $\begin{array}{c}0.00917 \\
(0.0091)\end{array}$ & & $\begin{array}{l}0.0223 \\
(0.0166)\end{array}$ & & $\begin{array}{c}-0.00979 \\
(0.0226)\end{array}$ & & $\begin{array}{c}-0.0652^{* * *} \\
(0.0233)\end{array}$ & \\
\hline Year $=1998$ & $\begin{array}{c}0.00108 \\
(0.0013)\end{array}$ & $\begin{array}{c}0.00368^{* * *} \\
(0.0013)\end{array}$ & $\begin{array}{c}-0.0237^{* * * *} \\
(0.0026)\end{array}$ & $\begin{array}{c}-0.0204^{* * *} \\
(0.0025)\end{array}$ & $\begin{array}{c}-0.110^{* * *} \\
(0.0029)\end{array}$ & $\begin{array}{c}-0.107^{* * *} \\
(0.0030)\end{array}$ & $\begin{array}{c}-0.0949^{* * *} \\
(0.0028)\end{array}$ & $\begin{array}{c}-0.0933^{* * *} \\
(0.0029)\end{array}$ \\
\hline $\mathrm{EV} *$ Year $=1998[\mathrm{EV}(98)]$ & $\begin{array}{c}-0.0608^{* * *} \\
(0.0086)\end{array}$ & $\begin{array}{c}-0.0489 * * * \\
(0.0092)\end{array}$ & $\begin{array}{c}-0.132^{* * *} \\
(0.0180)\end{array}$ & $\begin{array}{c}-0.126^{* * *} \\
(0.0214)\end{array}$ & $\begin{array}{c}-0.217^{* * *} \\
(0.0214)\end{array}$ & $\begin{array}{c}-0.231^{* * *} \\
(0.0296)\end{array}$ & $\begin{array}{c}-0.0860 * * * \\
(0.0257)\end{array}$ & $\begin{array}{c}-0.0922^{* * *} \\
(0.0251)\end{array}$ \\
\hline Poor People (\%) & $\begin{array}{c}0.00611^{*} \\
(0.0034)\end{array}$ & & $\begin{array}{c}-0.00887^{*} \\
(0.0048)\end{array}$ & & $\begin{array}{c}-0.0097 \\
(0.0068)\end{array}$ & & $\begin{array}{c}-0.0099 \\
(0.0065)\end{array}$ & \\
\hline EV $(98) *$ Poor People $(\%)$ & $\begin{array}{c}-0.0231^{* * *} \\
(0.0070)\end{array}$ & $\begin{array}{c}-0.0202^{* *} \\
(0.0080)\end{array}$ & $\begin{array}{c}-0.00158 \\
(0.0144)\end{array}$ & $\begin{array}{c}0.00681 \\
(0.0148)\end{array}$ & $\begin{array}{c}-0.0238 \\
(0.0230)\end{array}$ & $\begin{array}{c}-0.0193 \\
(0.0235)\end{array}$ & $\begin{array}{l}0.0066 \\
(0.0201)\end{array}$ & $\begin{array}{c}0.00104 \\
(0.0153)\end{array}$ \\
\hline $\mathrm{EV}^{*}$ Poor People $(\%)$ & $\begin{array}{c}0.0063 \\
(0.0093)\end{array}$ & & $\begin{array}{l}0.0129 \\
(0.0177)\end{array}$ & & $\begin{array}{c}0.0343 \\
(0.0252)\end{array}$ & & $\begin{array}{c}0.0365^{*} \\
(0.0216)\end{array}$ & \\
\hline Year $=1998^{*}$ Poor People $(\%)$ & $\begin{array}{c}0.00228 \\
(0.0026)\end{array}$ & $\begin{array}{c}0.000726 \\
(0.0025)\end{array}$ & $\begin{array}{c}0.0133^{* * * *} \\
(0.0049)\end{array}$ & $\begin{array}{c}0.0106^{* *} \\
(0.0048)\end{array}$ & $\begin{array}{c}-0.00587 \\
(0.0054)\end{array}$ & $\begin{array}{c}-0.0105^{* *} \\
(0.0051)\end{array}$ & $\begin{array}{c}0.000577 \\
(0.0050)\end{array}$ & $\begin{array}{c}-0.00264 \\
(0.0047)\end{array}$ \\
\hline Years of study & $\begin{array}{c}-0.0294^{* * *} \\
(0.0034)\end{array}$ & & $\begin{array}{c}-0.0241^{* * *} \\
(0.0052)\end{array}$ & & $\begin{array}{c}-0.00519 \\
(0.0071)\end{array}$ & & $\begin{array}{c}-0.0232^{* * *} \\
(0.0071)\end{array}$ & \\
\hline EV $(98) *$ Years of study & $\begin{array}{c}0.01 \\
(0.0065)\end{array}$ & $\begin{array}{c}0.00404 \\
(0.0072)\end{array}$ & $\begin{array}{c}0.0353^{* *} \\
(0.0146)\end{array}$ & $\begin{array}{c}0.0323 * * \\
(0.0150)\end{array}$ & $\begin{array}{c}0.0154 \\
(0.0175)\end{array}$ & $\begin{array}{c}0.0172 \\
(0.0181)\end{array}$ & $\begin{array}{l}0.0133 \\
(0.0152)\end{array}$ & $\begin{array}{c}0.0174 \\
(0.0131)\end{array}$ \\
\hline $\mathrm{EV}^{*}$ Years of study & $\begin{array}{c}-0.00559 \\
(0.0078)\end{array}$ & & $\begin{array}{c}-0.0146 \\
(0.0145)\end{array}$ & & $\begin{array}{c}-0.00804 \\
(0.0204)\end{array}$ & & $\begin{array}{r}0.0147 \\
(0.0175)\end{array}$ & \\
\hline Year $=1998^{*}$ Years of study & $\begin{array}{l}0.002 \\
(0.0030)\end{array}$ & $\begin{array}{c}0.00231 \\
(0.0030)\end{array}$ & $\begin{array}{c}-0.00755 \\
(0.0057)\end{array}$ & $\begin{array}{c}-0.00783 \\
(0.0057)\end{array}$ & $\begin{array}{c}-0.0129 * * \\
(0.0056)\end{array}$ & $\begin{array}{c}-0.00980^{*} \\
(0.0053)\end{array}$ & $\begin{array}{c}-0.00291 \\
(0.0056)\end{array}$ & $\begin{array}{c}-0.00157 \\
(0.0054)\end{array}$ \\
\hline Constant & $\begin{array}{c}0.248^{* * *} \\
(0.0174)\end{array}$ & $\begin{array}{c}0.178 * * * \\
(0.0152)\end{array}$ & $\begin{array}{c}0.275^{* * *} \\
(0.0163)\end{array}$ & $\begin{array}{c}0.254^{* * *} \\
(0.0320)\end{array}$ & $\begin{array}{c}0.391^{* * *} \\
(0.0188)\end{array}$ & $\begin{array}{c}0.335^{* * *} \\
(0.0344)\end{array}$ & $\begin{array}{c}0.242^{* * *} \\
(0.0163)\end{array}$ & $\begin{array}{c}0.304^{* * *} \\
(0.0293)\end{array}$ \\
\hline Observations & 2388 & $\begin{array}{c}2388 \\
\text { Robust } \\
* * * \mathrm{p} \\
\text { (1) Poole }\end{array}$ & $\begin{array}{c}2388 \\
\text { dard err } \\
.01,{ }^{* *} \mathrm{p} \\
\text { egression }\end{array}$ & $\begin{array}{c}2388 \\
\text { parenth } \\
* \mathrm{p}<0 . \\
\text { Fixed Ef }\end{array}$ & $\begin{array}{l}2388 \\
\text { es }\end{array}$ & 2388 & 2388 & 2388 \\
\hline
\end{tabular}

Using average years of schooling, percentage of poor people, longevity HDI, inequality (Theil Index), children mortality, house infrastructure (telephone and electricity), percentage of woman, mayor party, mayor vote share on the last election, number of electors (as deviation from the threshold), state/municipality fixed effects, electors age composition (young and elderly), political engagement as controls 
Table 63: Tight election race - Electronic voting impact on Blank Votes

\begin{tabular}{|c|c|c|c|c|c|c|c|c|}
\hline Dep. Var.: Blank & Presi & dent & Gove & rnor & Federal & Deputy & State & Deputy \\
\hline Regressions & (1) & (2) & (1) & (2) & (1) & (2) & (1) & (2) \\
\hline Electronic Voting (EV) & $\begin{array}{c}0.00913 \\
(0.0057)\end{array}$ & & $\begin{array}{c}0.0159 \\
(0.0134)\end{array}$ & & $\begin{array}{c}-0.00179 \\
(0.0156)\end{array}$ & & $\begin{array}{c}-0.0373^{* * *} \\
(0.0098)\end{array}$ & \\
\hline Year $=1998$ & $\begin{array}{c}0.0104^{* * *} \\
(0.0013)\end{array}$ & $\begin{array}{c}0.0115^{* * *} \\
(0.0013)\end{array}$ & $\begin{array}{c}-0.0134^{* * *} \\
(0.0024)\end{array}$ & $\begin{array}{c}-0.0107 * * * \\
(0.0024)\end{array}$ & $\begin{array}{c}-0.0524^{* * *} \\
(0.0018)\end{array}$ & $\begin{array}{c}-0.0510^{* * *} \\
(0.0019)\end{array}$ & $\begin{array}{c}-0.0653^{* * *} \\
(0.0017)\end{array}$ & $\begin{array}{c}-0.0649^{* * *} \\
(0.0017)\end{array}$ \\
\hline EV * Year $=1998[\mathrm{EV}(98)]$ & $\begin{array}{c}-0.0984^{* * *} \\
(0.0082)\end{array}$ & $\begin{array}{c}-0.1000 * * * \\
(0.0085)\end{array}$ & $\begin{array}{c}-0.194^{* * *} \\
(0.0175)\end{array}$ & $\begin{array}{c}-0.178^{* * *} \\
(0.0200)\end{array}$ & $\begin{array}{c}-0.0886^{* * *} \\
(0.0117)\end{array}$ & $\begin{array}{c}-0.106^{* * *} \\
(0.0162)\end{array}$ & $\begin{array}{c}-0.0146 \\
(0.0121)\end{array}$ & $\begin{array}{c}-0.0206 \\
(0.0135)\end{array}$ \\
\hline Poor People (\%) & $\begin{array}{c}0.00747^{* * *} \\
(0.0026)\end{array}$ & & $\begin{array}{c}-0.00673 \\
(0.0042)\end{array}$ & & $\begin{array}{c}-0.00128 \\
(0.0041)\end{array}$ & & $\begin{array}{c}-0.00112 \\
(0.0038)\end{array}$ & \\
\hline EV(98)*Poor People (\%) & $\begin{array}{c}-0.0207^{* * *} \\
(0.0065)\end{array}$ & $\begin{array}{c}-0.0193^{* * *} \\
(0.0063)\end{array}$ & $\begin{array}{c}-0.0308^{* *} \\
(0.0134)\end{array}$ & $\begin{array}{c}-0.0193 \\
(0.0131)\end{array}$ & $\begin{array}{c}-0.0535 * * * \\
(0.0134)\end{array}$ & $\begin{array}{c}-0.0418^{* * *} \\
(0.0120)\end{array}$ & $\begin{array}{c}-0.0334^{* * *} \\
(0.0091)\end{array}$ & $\begin{array}{c}-0.0304^{* * *} \\
(0.0086)\end{array}$ \\
\hline EV*Poor People (\%) & $\begin{array}{c}0.0137^{* * *} \\
(0.0053)\end{array}$ & & $\begin{array}{c}0.0196 \\
(0.0141)\end{array}$ & & $\begin{array}{c}0.0255 \\
(0.0162)\end{array}$ & & $\begin{array}{c}0.0291^{* * *} \\
(0.0090)\end{array}$ & \\
\hline Year $=1998^{*}$ Poor People $(\%)$ & $\begin{array}{c}-0.00429^{*} \\
(0.0023)\end{array}$ & $\begin{array}{c}-0.00478^{* *} \\
(0.0023)\end{array}$ & $\begin{array}{c}0.00895^{*} \\
(0.0046)\end{array}$ & $\begin{array}{c}0.00754^{*} \\
(0.0045)\end{array}$ & $\begin{array}{c}-0.00912^{* *} \\
(0.0036)\end{array}$ & $\begin{array}{c}-0.0113^{* * *} \\
(0.0035)\end{array}$ & $\begin{array}{c}-0.00348 \\
(0.0030)\end{array}$ & $\begin{array}{c}-0.00555^{*} \\
(0.0029)\end{array}$ \\
\hline Years of study & $\begin{array}{c}-0.0186^{* * *} \\
(0.0026)\end{array}$ & & $\begin{array}{c}-0.0245^{* * *} \\
(0.0045)\end{array}$ & & $\begin{array}{c}-0.0107^{* * *} \\
(0.0041)\end{array}$ & & $\begin{array}{c}-0.0256^{* * *} \\
(0.0040)\end{array}$ & \\
\hline EV $(98)^{*}$ Years of study & $\begin{array}{c}0.0231^{* * *} \\
(0.0060)\end{array}$ & $\begin{array}{c}0.0199^{* * *} \\
(0.0058)\end{array}$ & $\begin{array}{c}0.0432^{* * *} \\
(0.0119)\end{array}$ & $\begin{array}{c}0.0395^{* * *} \\
(0.0123)\end{array}$ & $\begin{array}{c}-0.0114 \\
(0.0105)\end{array}$ & $\begin{array}{c}-0.00932 \\
(0.0101)\end{array}$ & $\begin{array}{c}-0.0101 \\
(0.0073)\end{array}$ & $\begin{array}{c}-0.00935 \\
(0.0073)\end{array}$ \\
\hline EV*Years of study & $\begin{array}{c}0.0000984 \\
(0.0047)\end{array}$ & & $\begin{array}{c}-0.00624 \\
(0.0119)\end{array}$ & & $\begin{array}{c}0.00459 \\
(0.0135)\end{array}$ & & $\begin{array}{c}0.0208^{* * *} \\
(0.0079)\end{array}$ & \\
\hline Year $=1998^{*}$ Years of study & $\begin{array}{c}-0.00496^{*} \\
(0.0028)\end{array}$ & $\begin{array}{c}-0.00495^{*} \\
(0.0029)\end{array}$ & $\begin{array}{c}-0.00918^{*} \\
(0.0055)\end{array}$ & $\begin{array}{c}-0.00995^{*} \\
(0.0055)\end{array}$ & $\begin{array}{c}-0.00647^{*} \\
(0.0036)\end{array}$ & $\begin{array}{c}-0.00498 \\
(0.0037)\end{array}$ & $\begin{array}{c}0.00505 \\
(0.0033)\end{array}$ & $\begin{array}{c}0.00551^{*} \\
(0.0033)\end{array}$ \\
\hline Constant & $\begin{array}{c}0.104^{* * *} \\
(0.0090) \\
\end{array}$ & $\begin{array}{c}0.137^{* * *} \\
(0.0156)\end{array}$ & $\begin{array}{c}0.191^{* * *} \\
(0.0134)\end{array}$ & $\begin{array}{c}0.205^{* * *} \\
(0.0303)\end{array}$ & $\begin{array}{c}0.170^{* * *} \\
(0.0158) \\
\end{array}$ & $\begin{array}{c}0.189^{* * *} \\
(0.0196) \\
\end{array}$ & $\begin{array}{c}0.106^{* * *} \\
(0.0095)\end{array}$ & $\begin{array}{c}0.189^{* * *} \\
(0.0183)\end{array}$ \\
\hline Observations & 2388 & $\begin{array}{c}2388 \\
\text { Robust } \\
* * * \\
\text { (1) Pool }\end{array}$ & $\begin{array}{c}2388 \\
\text { hdard err } \\
.01, * * \mathrm{p} \\
\text { egression }\end{array}$ & $\begin{array}{c}2388 \\
\text { in paren } \\
5, * \mathrm{p}< \\
\text { Fixed }\end{array}$ & $\begin{array}{l}2388 \\
\text { s }\end{array}$ & 2388 & 2388 & 2388 \\
\hline
\end{tabular}

Using average years of schooling, percentage of poor people, longevity HDI, inequality (Theil Index), children mortality, house infrastructure (telephone and electricity), percentage of woman, mayor party, mayor vote share on the last election, number of electors (as deviation from the threshold), state/municipality fixed effects,electors age composition (young and elderly), political engagement as controls 
Table 64: Tight election race - Electronic voting impact on Spoiled Votes

\begin{tabular}{|c|c|c|c|c|c|c|c|c|}
\hline Dep. Var.: Spoiled & Pres & dent & Gov & ernor & Federal & Deputy & State & Deputy \\
\hline "Regressions & (1) & (2) & (1) & 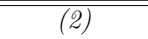 & (1) & (2) & (1) & (2) \\
\hline Electronic Voting (EV) & $\begin{array}{c}0.0000401 \\
(0.0058)\end{array}$ & & $\begin{array}{c}0.00641 \\
(0.0059)\end{array}$ & & $\begin{array}{l}-0.008 \\
(0.0141)\end{array}$ & & $\begin{array}{c}-0.0279^{*} \\
(0.0158)\end{array}$ & \\
\hline Year $=1998$ & $\begin{array}{c}-0.00933^{* * *} \\
(0.0010)\end{array}$ & $\begin{array}{c}-0.00782^{* * *} \\
(0.0010)\end{array}$ & $\begin{array}{c}-0.0103^{* * *} \\
(0.0006)\end{array}$ & $\begin{array}{c}-0.00962^{* * *} \\
(0.0006)\end{array}$ & $\begin{array}{c}-0.0577^{* * *} \\
(0.0019)\end{array}$ & $\begin{array}{c}-0.0565^{* * *} \\
(0.0020)\end{array}$ & $\begin{array}{c}-0.0296^{* * *} \\
(0.0016)\end{array}$ & $\begin{array}{c}-0.0284^{* * *} \\
(0.0017)\end{array}$ \\
\hline $\mathrm{EV} *$ Year $=1998[\mathrm{EV}(98)]$ & $\begin{array}{c}0.0376^{* * *} \\
(0.0077)\end{array}$ & $\begin{array}{c}0.0511^{* * * *} \\
(0.0086)\end{array}$ & $\begin{array}{c}0.0627^{* * *} \\
(0.0129)\end{array}$ & $\begin{array}{c}0.0517^{* * * *} \\
(0.0131)\end{array}$ & $\begin{array}{c}-0.129^{* * *} \\
(0.0182)\end{array}$ & $\begin{array}{c}-0.125^{* * *} \\
(0.0207)\end{array}$ & $\begin{array}{c}-0.0714^{* * *} \\
(0.0175)\end{array}$ & $\begin{array}{c}-0.0715^{* * *} \\
(0.0169)\end{array}$ \\
\hline Poor People $(\%)$ & $\begin{array}{c}-0.00136 \\
(0.0018)\end{array}$ & & $\begin{array}{c}-0.00214 \\
(0.0015)\end{array}$ & & $\begin{array}{c}-0.00842^{*} \\
(0.0043)\end{array}$ & & $\begin{array}{c}-0.00878^{* *} \\
(0.0036)\end{array}$ & \\
\hline EV $(98) *$ Poor People $(\%)$ & $\begin{array}{c}-0.00236 \\
(0.0063)\end{array}$ & $\begin{array}{c}-0.000876 \\
(0.0072)\end{array}$ & $\begin{array}{c}0.0293^{* * *} \\
(0.0097)\end{array}$ & $\begin{array}{c}0.0261^{\text {*** }} \\
(0.0097)\end{array}$ & $\begin{array}{c}0.0298^{*} \\
(0.0163)\end{array}$ & $\begin{array}{r}0.0225 \\
(0.0168)\end{array}$ & $\begin{array}{c}0.0400^{* * *} \\
(0.0151)\end{array}$ & $\begin{array}{c}0.0315^{* *} \\
(0.0126)\end{array}$ \\
\hline EV*Poor People $(\%)$ & $\begin{array}{c}-0.0074 \\
(0.0058)\end{array}$ & & $\begin{array}{c}-0.00675 \\
(0.0061)\end{array}$ & & $\begin{array}{c}0.00887 \\
(0.0138)\end{array}$ & & $\begin{array}{c}0.00747 \\
(0.0144)\end{array}$ & \\
\hline Year $=1998^{*}$ Poor People $(\%)$ & $\begin{array}{c}0.00657^{* * *} \\
(0.0018)\end{array}$ & $\begin{array}{c}0.00551^{* * *} \\
(0.0017)\end{array}$ & $\begin{array}{c}0.00438^{* * *} \\
(0.0011)\end{array}$ & $\begin{array}{c}0.00309 * * * \\
(0.0011)\end{array}$ & $\begin{array}{c}0.00325 \\
(0.0033)\end{array}$ & $\begin{array}{c}0.000767 \\
(0.0032)\end{array}$ & $\begin{array}{c}0.00406 \\
(0.0030)\end{array}$ & $\begin{array}{c}0.00291 \\
(0.0029)\end{array}$ \\
\hline Years of study & $\begin{array}{c}-0.0109^{* * *} \\
(0.0020)\end{array}$ & & $\begin{array}{c}0.000403 \\
(0.0016)\end{array}$ & & $\begin{array}{c}0.00551 \\
(0.0046)\end{array}$ & & $\begin{array}{c}0.00235 \\
(0.0041)\end{array}$ & \\
\hline EV(98)*Years of study & $\begin{array}{c}-0.0131^{* * *} \\
(0.0049)\end{array}$ & $\begin{array}{c}-0.0159 \text { *** } \\
(0.0054)\end{array}$ & $\begin{array}{c}-0.00793 \\
(0.0084)\end{array}$ & $\begin{array}{c}-0.00723 \\
(0.0078)\end{array}$ & $\begin{array}{c}0.0268^{* *} \\
(0.0120)\end{array}$ & $\begin{array}{c}0.0266^{* *} \\
(0.0120)\end{array}$ & $\begin{array}{c}0.0234^{*} \\
(0.0120)\end{array}$ & $\begin{array}{c}0.0267^{* * *} \\
(0.0101)\end{array}$ \\
\hline $\mathrm{EV}^{*}$ Years of study & $\begin{array}{c}-0.00569 \\
(0.0049)\end{array}$ & & $\begin{array}{c}-0.00833 \\
(0.0052)\end{array}$ & & $\begin{array}{c}-0.0126 \\
(0.0112)\end{array}$ & & $\begin{array}{c}-0.00615 \\
(0.0119)\end{array}$ & \\
\hline Year $=1998^{*}$ Years of study & $\begin{array}{c}0.00696^{\text {*** }} \\
(0.0020)\end{array}$ & $\begin{array}{c}0.00726^{* * *} \\
(0.0020)\end{array}$ & $\begin{array}{c}0.00163 \\
(0.0013)\end{array}$ & $\begin{array}{c}0.00211^{*} \\
(0.0012)\end{array}$ & $\begin{array}{c}-0.00643^{*} \\
(0.0036)\end{array}$ & $\begin{array}{c}-0.00482 \\
(0.0034)\end{array}$ & $\begin{array}{c}-0.00796^{* *} \\
(0.0033)\end{array}$ & $\begin{array}{c}-0.00709^{* *} \\
(0.0031)\end{array}$ \\
\hline Constant & $\begin{array}{c}0.144^{* * *} \\
(0.0164)\end{array}$ & $\begin{array}{c}0.0409^{* * *} \\
(0.0111)\end{array}$ & $\begin{array}{c}0.0837^{* * * *} \\
(0.0078)\end{array}$ & $\begin{array}{c}0.0492^{* * * *} \\
(0.0097)\end{array}$ & $\begin{array}{c}0.221^{* * *} \\
(0.0114)\end{array}$ & $\begin{array}{c}0.146^{* * *} * \\
(0.0232)\end{array}$ & $\begin{array}{c}0.136^{* * *} \\
(0.0093)\end{array}$ & $\begin{array}{c}0.115^{* * *} \\
(0.0163)\end{array}$ \\
\hline Observations & 2388 & $\begin{array}{l}2388 \\
\text { Robust } \\
* * * \\
\text { (1) Pool }\end{array}$ & $\begin{array}{c}2388 \\
\text { adard er } \\
.01, * * \mathrm{p} \\
\text { egressios }\end{array}$ & $\begin{array}{c}2388 \\
\text { parenth } \\
5, * \mathrm{p}<0 . \\
\text { Fixed Ef }\end{array}$ & 2388 & 2388 & 2388 & 2388 \\
\hline
\end{tabular}

Using average years of schooling, percentage of poor people, longevity HDI, inequality (Theil Index), children mortality, house infrastructure (telephone and electricity), percentage of woman, mayor party, mayor vote share on the last election, number of electors (as deviation from the threshold), state/municipality fixed effects, electors age composition (young and elderly), political engagement as controls 
Table 65: Tight election race - Electronic voting impact on Turnout

\begin{tabular}{|c|c|c|}
\hline \multicolumn{3}{|l|}{ Dep. Var.: Turnout } \\
\hline Regressions & (1) & (2) \\
\hline Electronic Voting (EV) & $\begin{array}{c}0.0274^{* *} \\
(0.0132)\end{array}$ & \\
\hline Year $=1998$ & $\begin{array}{c}-0.0165^{* * *} \\
(0.0018)\end{array}$ & $\begin{array}{c}-0.0123^{* * *} \\
(0.0016)\end{array}$ \\
\hline EV * Year $=1998[\mathrm{EV}(98)]$ & $\begin{array}{c}-0.0209^{*} \\
(0.0125)\end{array}$ & $\begin{array}{c}-0.0338^{* * *} \\
(0.0122)\end{array}$ \\
\hline Poor People (\%) & $\begin{array}{c}-0.0283^{* * *} \\
(0.0047)\end{array}$ & \\
\hline EV $(98) *$ Poor People (\%) & $\begin{array}{c}0.0254^{* *} \\
(0.0114)\end{array}$ & $\begin{array}{c}0.0240^{* *} \\
(0.0110)\end{array}$ \\
\hline EV*Poor People (\%) & $\begin{array}{c}-0.00577 \\
(0.0117)\end{array}$ & \\
\hline Year $=1998^{*}$ Poor People $(\%)$ & $\begin{array}{c}-0.000056 \\
(0.0036)\end{array}$ & $\begin{array}{c}0.00218 \\
(0.0029)\end{array}$ \\
\hline Years of study & $\begin{array}{c}0.0317^{* * *} \\
(0.0053)\end{array}$ & \\
\hline EV $(98)^{*}$ Years of study & $\begin{array}{c}0.0203^{* *} \\
(0.0096)\end{array}$ & $\begin{array}{c}0.0259^{* *} \\
(0.0101)\end{array}$ \\
\hline $\mathrm{EV}^{*}$ Years of study & $\begin{array}{c}0.00804 \\
(0.0124)\end{array}$ & \\
\hline Year $=1998^{*}$ Years of study & $\begin{array}{c}-0.00816^{* *} \\
(0.0039)\end{array}$ & $\begin{array}{c}-0.00446 \\
(0.0030)\end{array}$ \\
\hline Constant & $\begin{array}{c}0.791 * * * \\
(0.0152)\end{array}$ & $\begin{array}{c}0.668^{* * *} \\
(0.0246)\end{array}$ \\
\hline Observations & 2388 & 2388 \\
\hline
\end{tabular}

Using average years of schooling, percentage of poor people, longevity HDI, inequality (Theil Index), children mortality, house infrastructure (telephone and electricity), percentage of woman, mayor party, mayor vote share on the last election, number of electors (as deviation from the threshold), state/municipality fixed effects,electors age composition (young and elderly), political engagement as controls 
Table 66: Tight election race - Electronic voting impact on Party Votes

\begin{tabular}{|c|c|c|c|c|}
\hline \multirow{3}{*}{$\begin{array}{l}\text { Dep. Var.: Party Vote } \\
\text { Regressions } \\
\text { Electronic Voting (EV) }\end{array}$} & \multicolumn{2}{|c|}{ Federal Deputy } & \multicolumn{2}{|c|}{ State Deputy } \\
\hline & $\overline{~(1) ~}$ & (2) & (1) & 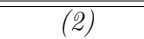 \\
\hline & -0.00958 & & -0.013 & \\
\hline Year $=1998$ & $\begin{array}{c}(0.0122) \\
0.0140 * * * \\
(0.0011)\end{array}$ & $\begin{array}{c}0.0139^{* * *} \\
(0.0011)\end{array}$ & $\begin{array}{c}(0.0117) \\
0.0143^{* * *} \\
(0.0010)\end{array}$ & $\begin{array}{c}0.0140 * * * \\
(0.0010)\end{array}$ \\
\hline EV * Year $=1998[\mathrm{EV}(98)]$ & $\begin{array}{c}0.0927^{* * *} \\
(0.0203)\end{array}$ & $\begin{array}{l}0.0930^{* * *} \\
(0.0208)\end{array}$ & $\begin{array}{c}0.145^{* * *} \\
(0.0164)\end{array}$ & $\begin{array}{c}0.150^{* * *} \\
(0.0165)\end{array}$ \\
\hline Poor People (\%) & $\begin{array}{c}-0.00496 * * \\
(0.0024)\end{array}$ & & $\begin{array}{c}-0.00473^{* *} \\
(0.0020)\end{array}$ & \\
\hline EV(98)*Poor People (\%) & $\begin{array}{c}0.0283^{*} \\
(0.0166)\end{array}$ & $\begin{array}{c}0.0365^{* *} \\
(0.0169)\end{array}$ & $\begin{array}{c}0.00845 \\
(0.0123)\end{array}$ & $\begin{array}{c}0.0113 \\
(0.0123)\end{array}$ \\
\hline EV*Poor People $(\%)$ & $\begin{array}{c}-0.0365^{* *} \\
(0.0165)\end{array}$ & & $\begin{array}{c}-0.0309 * * \\
(0.0142)\end{array}$ & \\
\hline Year $=1998 *$ Poor People $(\%)$ & $\begin{array}{c}0.00129 \\
(0.0024)\end{array}$ & $\begin{array}{c}0.00105 \\
(0.0024)\end{array}$ & $\begin{array}{c}0.00589^{* * *} \\
(0.0020)\end{array}$ & $\begin{array}{c}0.00596^{* * *} \\
(0.0020)\end{array}$ \\
\hline Years of study & $\begin{array}{c}0.00566^{* *} \\
(0.0027)\end{array}$ & & $\begin{array}{c}0.00263 \\
(0.0021)\end{array}$ & \\
\hline $\mathrm{EV}(98)^{*}$ Years of study & $\begin{array}{c}-0.0131 \\
(0.0137)\end{array}$ & $\begin{array}{c}0.00352 \\
(0.0161)\end{array}$ & $\begin{array}{c}-0.0230^{* *} \\
(0.0110)\end{array}$ & $\begin{array}{c}-0.0169 \\
(0.0114)\end{array}$ \\
\hline $\mathrm{EV}^{*}$ Years of study & $\begin{array}{c}-0.0359 * * * \\
(0.0139)\end{array}$ & & $\begin{array}{c}-0.0277^{* *} \\
(0.0123)\end{array}$ & \\
\hline Year $=1998^{*}$ Years of study & $\begin{array}{c}-0.00655^{* * *} \\
(0.0021)\end{array}$ & $\begin{array}{c}-0.00674^{* * *} \\
(0.0021)\end{array}$ & $\begin{array}{c}-0.00295 \\
(0.0019)\end{array}$ & $\begin{array}{c}-0.00315 \\
(0.0019)\end{array}$ \\
\hline Constant & $\begin{array}{c}0.0472^{* * *} \\
(0.0072)\end{array}$ & $\begin{array}{c}0.0390 * * \\
(0.0172)\end{array}$ & $\begin{array}{c}0.0283^{* * *} \\
(0.0046)\end{array}$ & $\begin{array}{c}0.0337^{* *} \\
(0.0135)\end{array}$ \\
\hline Observations & $\begin{array}{c}2388 \\
\text { andard e } \\
0.01, * *\end{array}$ & $\begin{array}{c}2388 \\
\text { in paren } \\
05,{ }^{*} \mathrm{p}<\end{array}$ & 2388 & 2388 \\
\hline
\end{tabular}

(1) Pooled regression; (2) Fixed Effects

Using average years of schooling, percentage of poor people, longevity HDI, inequality (Theil Index), children mortality, house infrastructure (telephone and electricity), percentage of woman, mayor party, mayor vote share on the last election, number of electors (as deviation from the threshold), state/municipality fixed effects,electors age composition (young and elderly), political engagement as controls 
Table 67: Tight election race - Electronic voting impact on Party Fractionalization

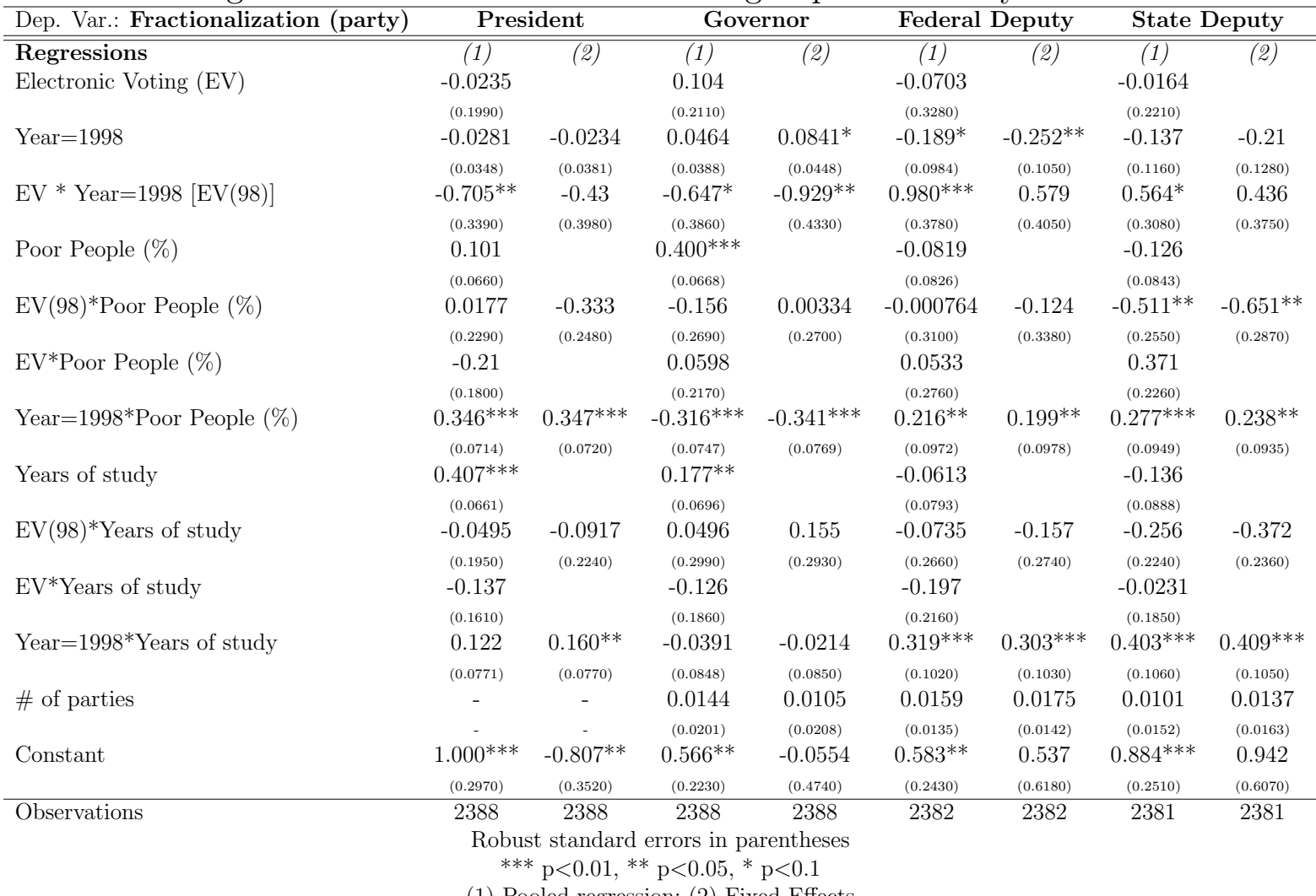

(1) Pooled regression; (2) Fixed Effects

Using average years of schooling, percentage of poor people, longevity HDI, inequality (Theil Index), children mortality, house infrastructure (telephone and electricity), percentage of woman, mayor party, mayor vote share on the last election, number of electors (as deviation from the threshold), state/municipality fixed effects, electors age composition (young and elderly), political engagement as controls 
Table 68: Tight election race - Electronic voting impact on Candidate Fractionalization

\begin{tabular}{|c|c|c|c|c|}
\hline Dep. Var.: Fractionalization (cand.) & \multicolumn{2}{|c|}{ Federal Deputy } & \multicolumn{2}{|c|}{ State Deputy } \\
\hline Regressions & (1) & (2) & (1) & (2) \\
\hline \multirow[t]{2}{*}{ Electronic Voting (EV) } & -0.363 & & $-0.725^{* *}$ & \\
\hline & $(0.2660)$ & & $(0.3580)$ & \\
\hline \multirow[t]{2}{*}{ Year $=1998$} & -0.0248 & 0.00107 & -0.0437 & -0.0629 \\
\hline & $(0.0417)$ & $(0.0434)$ & $(0.0486)$ & $(0.0502)$ \\
\hline \multirow[t]{2}{*}{ EV * Year $=1998[\mathrm{EV}(98)]$} & -0.016 & -0.0888 & 0.313 & -0.0525 \\
\hline & $(0.4230)$ & $(0.4600)$ & $(0.3530)$ & $(0.3440)$ \\
\hline \multirow{2}{*}{ Poor People (\%) } & $0.225^{* * *}$ & & $0.220^{* * *}$ & \\
\hline & $(0.0772)$ & & $(0.0843)$ & \\
\hline \multirow[t]{2}{*}{ EV $(98) *$ Poor People (\%) } & $0.566^{* *}$ & $0.584^{*}$ & -0.00972 & -0.0511 \\
\hline & $(0.2810)$ & $(0.3030)$ & $(0.2900)$ & $(0.2140)$ \\
\hline \multirow[t]{2}{*}{ EV*Poor People (\%) } & -0.217 & & 0.463 & \\
\hline & $(0.2820)$ & & $(0.3020)$ & \\
\hline \multirow[t]{2}{*}{ Year $=1998^{*}$ Poor People $(\%)$} & 0.0321 & -0.00273 & 0.0695 & 0.0857 \\
\hline & $(0.0798)$ & $(0.0786)$ & $(0.0790)$ & $(0.0797)$ \\
\hline \multirow[t]{2}{*}{ Years of study } & $0.437^{* * *}$ & & 0.135 & \\
\hline & $(0.0794)$ & & $(0.0910)$ & \\
\hline \multirow{2}{*}{$\mathrm{EV}(98)^{*}$ Years of study } & 0.0464 & 0.113 & -0.153 & -0.00656 \\
\hline & $(0.2440)$ & $(0.2200)$ & $(0.2260)$ & $(0.2230)$ \\
\hline \multirow[t]{2}{*}{ EV*Years of study } & -0.29 & & 0.157 & \\
\hline & $(0.2340)$ & & $(0.2410)$ & \\
\hline \multirow[t]{2}{*}{ Year $=1998^{*}$ Years of study } & 0.00257 & 0.0512 & 0.0839 & 0.105 \\
\hline & $(0.0737)$ & $(0.0722)$ & $(0.0818)$ & $(0.0821)$ \\
\hline \multirow[t]{2}{*}{ \# of candidates } & 0.00129 & 0.00118 & 0.000501 & $0.000709^{* *}$ \\
\hline & $(0.0008)$ & $(0.0008)$ & $(0.0003)$ & $(0.0003)$ \\
\hline \multirow[t]{2}{*}{ Constant } & $1.290^{* * *}$ & -0.373 & $1.061^{* * *}$ & -0.398 \\
\hline & $(0.2600)$ & $(0.4620)$ & $(0.3100)$ & $(0.4300)$ \\
\hline Observations & 2388 & 2388 & 2388 & 2388 \\
\hline
\end{tabular}

Using average years of schooling, percentage of poor people, longevity HDI, inequality (Theil Index),children mortality, house infrastructure (telephone and electricity), percentage of woman, mayor party, mayor vote share on the last election, number of electors (as deviation from the threshold), state/municipality fixed effects, electors age composition (young and elderly), political engagement as controls 
Table 69: Tight election race - Electronic voting impact on the "first" vote

\begin{tabular}{|c|c|c|}
\hline Dep. Var.: Invalid & \multicolumn{2}{|c|}{ First } \\
\hline Regressions & (1) & (2) \\
\hline Electronic Voting (EV) & $\begin{array}{c}0.00948 \\
(0.0092)\end{array}$ & \\
\hline Year $=1998$ & $\begin{array}{c}0.0012 \\
(0.0013)\end{array}$ & $\begin{array}{c}0.00390 * * * \\
(0.0013)\end{array}$ \\
\hline EV $*$ Year $=1998[\mathrm{EV}(98)]$ & $\begin{array}{c}-0.157^{* * *} \\
(0.0113)\end{array}$ & $\begin{array}{c}-0.160^{* * *} \\
(0.0134)\end{array}$ \\
\hline Poor People (\%) & $\begin{array}{c}0.00601^{*} \\
(0.0034)\end{array}$ & \\
\hline EV $(98) *$ Poor People (\%) & $\begin{array}{c}-0.0289^{* * *} \\
(0.0092)\end{array}$ & $\begin{array}{c}-0.0280^{* * *} \\
(0.0092)\end{array}$ \\
\hline $\mathrm{EV}^{*}$ Poor People $(\%)$ & $\begin{array}{c}0.00592 \\
(0.0093)\end{array}$ & \\
\hline Year $=1998^{*}$ Poor People $(\%)$ & $\begin{array}{c}0.00241 \\
(0.0026)\end{array}$ & $\begin{array}{c}0.000805 \\
(0.0025)\end{array}$ \\
\hline Years of study & $\begin{array}{c}-0.0296^{* * *} \\
(0.0034)\end{array}$ & \\
\hline EV $(98)^{*}$ Years of study & $\begin{array}{c}0.0364^{* * *} \\
(0.0078)\end{array}$ & $\begin{array}{c}0.0332^{* * *} \\
(0.0081)\end{array}$ \\
\hline $\mathrm{EV}^{*}$ Years of study & $\begin{array}{c}-0.00584 \\
(0.0078)\end{array}$ & \\
\hline Year $=1998^{*}$ Years of study & $\begin{array}{c}0.00238 \\
(0.0030)\end{array}$ & $\begin{array}{c}0.00272 \\
(0.0030)\end{array}$ \\
\hline Constant & $\begin{array}{c}0.248^{* * *} \\
(0.0175) \\
\end{array}$ & $\begin{array}{c}0.183^{* * *} \\
(0.0157)\end{array}$ \\
\hline Observations & 2388 & 2388 \\
\hline
\end{tabular}

(1) Pooled regression; (2) Fixed Effects

Using average years of schooling, percentage of poor people, longevity HDI, inequality (Theil Index), children mortality, house infrastructure (telephone and electricity), percentage of woman, mayor party, mayor vote share on the last election, number of electors (as deviation from the threshold), state/municipality fixed effects,electors age composition (young and elderly), political engagement as controls 
Table 70: Tight election race - Electronic voting impact on PT party code votes (over total party code votes)

\begin{tabular}{|c|c|c|c|c|c|c|c|c|}
\hline Dep. Var.: PT Party Code Vote Share & Pres & dent & Gove & rnor & Federal & Deputy & State 1 & eputy \\
\hline Regressions & (1) & (2) & (1) & (2) & (1) & (2) & (1) & (2) \\
\hline Electronic Voting (EV) & $0.0474^{*}$ & & 0.0101 & & 0.0354 & & 0.0112 & \\
\hline & (1) & (2) & (1) & (2) & (1) & (2) & (1) & (2) \\
\hline Year $=1998$ & $\begin{array}{c}0.0329^{* * *} \\
(0.0031)\end{array}$ & $\begin{array}{c}0.0409^{* * *} \\
(0.0028)\end{array}$ & $\begin{array}{c}0.0396^{* * *} \\
(0.0034)\end{array}$ & $\begin{array}{c}0.0483^{* * *} \\
(0.0036)\end{array}$ & $\begin{array}{c}-0.207^{* * *} \\
(0.0064)\end{array}$ & $\begin{array}{c}-0.201^{* * *} \\
(0.0070)\end{array}$ & $\begin{array}{c}-0.210^{* * *} \\
(0.0072)\end{array}$ & $\begin{array}{c}-0.202^{* * *} \\
(0.0080)\end{array}$ \\
\hline EV $*$ Year $=1998[\mathrm{EV}(98)]$ & $\begin{array}{c}-0.106^{* * *} \\
(0.0269)\end{array}$ & $\begin{array}{c}-0.117^{* * *} \\
(0.0280)\end{array}$ & $\begin{array}{c}-0.0269 \\
(0.0449)\end{array}$ & $\begin{array}{c}-0.0291 \\
(0.0371)\end{array}$ & $\begin{array}{c}-0.113^{* *} \\
(0.0498)\end{array}$ & $\begin{array}{c}-0.101^{*} \\
(0.0603)\end{array}$ & $\begin{array}{c}-0.113^{* *} \\
(0.0528)\end{array}$ & $\begin{array}{c}-0.144^{*} \\
(0.0738)\end{array}$ \\
\hline Poor People $(\%)$ & $\begin{array}{c}0.0461^{* * *} \\
(0.0085)\end{array}$ & & $\begin{array}{c}0.0235^{* * *} \\
(0.0066)\end{array}$ & & $\begin{array}{c}0.0288^{* *} \\
(0.0142)\end{array}$ & & $\begin{array}{c}0.0406^{* *} \\
(0.0163)\end{array}$ & \\
\hline EV $(98) *$ Poor People (\%) & $\begin{array}{c}0.0299 \\
(0.0247)\end{array}$ & $\begin{array}{c}0.0291 \\
(0.0218)\end{array}$ & $\begin{array}{l}0.0172 \\
(0.0290)\end{array}$ & $\begin{array}{c}0.0327 \\
(0.0362)\end{array}$ & $\begin{array}{c}0.00956 \\
(0.0416)\end{array}$ & $\begin{array}{c}0.0406 \\
(0.0427)\end{array}$ & $\begin{array}{c}0.0852^{*} \\
(0.0442)\end{array}$ & $\begin{array}{c}0.129^{* * *} \\
(0.0462)\end{array}$ \\
\hline EV*Poor People (\%) & $\begin{array}{c}-0.0271 \\
(0.0339)\end{array}$ & & $\begin{array}{c}0.0273 \\
(0.0372)\end{array}$ & & $\begin{array}{c}0.00968 \\
(0.0417)\end{array}$ & & $\begin{array}{c}-0.0367 \\
(0.0409)\end{array}$ & \\
\hline Year $=1998 *$ Poor People $(\%)$ & $\begin{array}{c}0.0279^{* * *} \\
(0.0063)\end{array}$ & $\begin{array}{c}0.0284^{\text {*** }} \\
(0.0057)\end{array}$ & $\begin{array}{c}-0.00332 \\
(0.0069)\end{array}$ & $\begin{array}{c}-0.00219 \\
(0.0071)\end{array}$ & $\begin{array}{c}-0.0211 \\
(0.0129)\end{array}$ & $\begin{array}{c}-0.0215^{*} \\
(0.0130)\end{array}$ & $\begin{array}{c}-0.0363^{* *} \\
(0.0146)\end{array}$ & $\begin{array}{c}-0.0336^{* *} \\
(0.0149)\end{array}$ \\
\hline EV $(98) *$ Years of study & $\begin{array}{c}0.0225 \\
(0.0205)\end{array}$ & $\begin{array}{c}0.0234 \\
(0.0195)\end{array}$ & $\begin{array}{c}0.0295 \\
(0.0238)\end{array}$ & $\begin{array}{c}0.0382 \\
(0.0273)\end{array}$ & $\begin{array}{c}0.0285 \\
(0.0390)\end{array}$ & $\begin{array}{c}0.0433 \\
(0.0380)\end{array}$ & $\begin{array}{c}0.0639 \\
(0.0426)\end{array}$ & $\begin{array}{c}0.0940 * * \\
(0.0420)\end{array}$ \\
\hline Mayor $(\mathrm{PT}=1)$ & $\begin{array}{c}0.0774 \\
(0.0503)\end{array}$ & $\begin{array}{c}-0.000414 \\
(0.0305)\end{array}$ & $\begin{array}{c}0.0902^{*} \\
(0.0477)\end{array}$ & $\begin{array}{c}-0.0582 \\
(0.0435)\end{array}$ & $\begin{array}{c}0.130^{*} \\
(0.0750)\end{array}$ & $\begin{array}{c}0.0423 \\
(0.0493)\end{array}$ & $\begin{array}{c}0.190^{* *} \\
(0.0793)\end{array}$ & $\begin{array}{l}0.102 \\
(0.0618)\end{array}$ \\
\hline Year $=1998^{*}$ Mayor $(\mathrm{PT}=1)$ & $\begin{array}{c}-0.0381 \\
(0.0444)\end{array}$ & $\begin{array}{c}-0.0477 \\
(0.0315)\end{array}$ & $\begin{array}{c}-0.00932 \\
(0.0428)\end{array}$ & $\begin{array}{c}0.0466 \\
(0.0496)\end{array}$ & $\begin{array}{c}-0.0741 \\
(0.0687)\end{array}$ & $\begin{array}{c}-0.0528 \\
(0.0554)\end{array}$ & $\begin{array}{c}-0.137^{*} \\
(0.0753)\end{array}$ & $\begin{array}{c}-0.113^{*} \\
(0.0674)\end{array}$ \\
\hline $\mathrm{EV}^{*}$ Mayor $(\mathrm{PT}=1)$ & $\begin{array}{c}-0.0721 \\
(0.0585)\end{array}$ & $\begin{array}{c}-0.0559 \\
(0.0430)\end{array}$ & $\begin{array}{c}-0.0423 \\
(0.0556)\end{array}$ & $\begin{array}{c}0.0184 \\
(0.0580)\end{array}$ & $\begin{array}{l}-0.092 \\
(0.0864)\end{array}$ & $\begin{array}{c}-0.1 \\
(0.0748)\end{array}$ & $\begin{array}{c}-0.172^{* *} \\
(0.0867)\end{array}$ & $\begin{array}{c}-0.198^{* *} \\
(0.0853)\end{array}$ \\
\hline $\mathrm{EV}(98) *$ Mayor $(\mathrm{PT}=1)$ & $\begin{array}{l}0.019 \\
(0.0644)\end{array}$ & $\begin{array}{c}0.0112 \\
(0.0526)\end{array}$ & $\begin{array}{c}-0.0755 \\
(0.0596)\end{array}$ & $\begin{array}{c}-0.137^{*} \\
(0.0727)\end{array}$ & $\begin{array}{c}0.0272 \\
(0.0881)\end{array}$ & $\begin{array}{c}0.0372 \\
(0.1050)\end{array}$ & $\begin{array}{l}0.118 \\
(0.0921)\end{array}$ & $\begin{array}{l}0.188 \\
(0.1170)\end{array}$ \\
\hline Constant & $\begin{array}{c}0.223^{* * *} \\
(0.0421)\end{array}$ & $\begin{array}{c}0.124^{* * *} \\
(0.0308)\end{array}$ & $\begin{array}{c}0.351^{* * *} \\
(0.0500)\end{array}$ & $\begin{array}{c}0.0473 \\
(0.0459)\end{array}$ & $\begin{array}{c}0.434 * * * \\
(0.0565) \\
\end{array}$ & $\begin{array}{c}0.372^{* * *} \\
(0.0706)\end{array}$ & $\begin{array}{c}0.450^{* * *} \\
(0.0484)\end{array}$ & $\begin{array}{c}0.258^{* * *} \\
(0.0862)\end{array}$ \\
\hline Observations & 2388 & 2388 & 1769 & 1769 & 2388 & 2388 & 2388 & 2388 \\
\hline
\end{tabular}

(1) Pooled regression; (2) Fixed Effects

Using average years of schooling, percentage of poor people, longevity HDI, inequality (Theil Index), children mortality, house infrastructure (telephone and electricity), percentage of woman, mayor party, mayor vote share on the last election, number of electors (as deviation from the threshold), state/municipality fixed effects,electors age composition (young and elderly), political engagement as controls 
Table 71: Tight election race - Electronic voting impact on PSDB Votes party code votes (over total party code votes)

\begin{tabular}{|c|c|c|c|c|c|c|c|c|}
\hline \multirow{2}{*}{$\begin{array}{l}\text { Dep. Var.: PSDB Party Code Vote Share } \\
\text { Regressions }\end{array}$} & \multicolumn{2}{|c|}{ President } & \multicolumn{2}{|c|}{ Governor } & \multicolumn{2}{|c|}{ Federal Deputy } & \multicolumn{2}{|c|}{ State Deputy } \\
\hline & $\overline{(11)}$ & (2) & (1) & (2) & $\overline{(1)}$ & (2) & (1) & (2) \\
\hline \multirow[t]{2}{*}{ Electronic Voting (EV) } & -0.015 & & 0.0453 & & 0.00393 & & 0.018 & \\
\hline & $(0.0354)$ & & $(0.0360)$ & & $(0.0257)$ & & $(0.0260)$ & \\
\hline \multirow[t]{2}{*}{ Year $=1998$} & $0.00902^{*}$ & $0.0108^{* *}$ & $0.0545^{* * *}$ & $0.0648^{* * *}$ & $0.140^{* * *}$ & $0.138^{* * *}$ & $0.127^{* * *}$ & $0.129 * * *$ \\
\hline & $(0.0049)$ & $(0.0051)$ & $(0.0120)$ & $(0.0158)$ & $(0.0055)$ & $(0.0062)$ & $(0.0056)$ & $(0.0064)$ \\
\hline \multirow[t]{2}{*}{ EV * Year $=1998[\mathrm{EV}(98)]$} & $0.0827^{* *}$ & 0.0595 & 0.0706 & -0.0503 & $-0.102^{* * *}$ & $-0.0648^{*}$ & 0.0254 & 0.062 \\
\hline & $(0.0400)$ & $(0.0377)$ & $(0.0477)$ & $(0.0951)$ & $(0.0345)$ & $(0.0391)$ & $(0.0305)$ & $(0.0380)$ \\
\hline \multirow[t]{2}{*}{ Poor People (\%) } & $-0.0516^{* * *}$ & & $-0.0806^{* * *}$ & & -0.0132 & & -0.00565 & \\
\hline & $(0.0102)$ & & $(0.0153)$ & & $(0.0083)$ & & $(0.0083)$ & \\
\hline \multirow[t]{2}{*}{ EV $(98) *$ Poor People (\%) } & -0.0379 & -0.0149 & -0.00737 & -0.00569 & -0.0252 & -0.0138 & 0.0382 & 0.0414 \\
\hline & $(0.0335)$ & $(0.0322)$ & $(0.0503)$ & $(0.0589)$ & $(0.0263)$ & $(0.0269)$ & $(0.0262)$ & $(0.0280)$ \\
\hline \multirow[t]{2}{*}{ EV*Poor People (\%) } & 0.0493 & & 0.00979 & & 0.00853 & & 0.00324 & \\
\hline & $(0.0328)$ & & $(0.0358)$ & & $(0.0275)$ & & $(0.0274)$ & \\
\hline \multirow[t]{2}{*}{ Year $=1998 *$ Poor People $(\%)$} & $-0.0393 * * *$ & $-0.0410^{* * *}$ & $0.159^{* * *}$ & $0.174^{* * *}$ & -0.00705 & -0.00468 & -0.00464 & -0.00287 \\
\hline & $(0.0095)$ & (0.0093) & $(0.0176)$ & $(0.0220)$ & $(0.0105)$ & $(0.0105)$ & $(0.0108)$ & $(0.0105)$ \\
\hline \multirow[t]{2}{*}{ EV(98)*Years of study } & -0.0138 & -0.0163 & $-0.125^{* * *}$ & $-0.144^{* *}$ & -0.0287 & -0.0365 & -0.0243 & -0.0199 \\
\hline & $(0.0264)$ & $(0.0274)$ & $(0.0445)$ & $(0.0632)$ & $(0.0252)$ & $(0.0274)$ & $(0.0247)$ & $(0.0278)$ \\
\hline \multirow[t]{2}{*}{ Mayor $(\mathrm{PSDB}=1)$} & $0.0546^{* * *}$ & $0.0770^{* * *}$ & 0.0361 & 0.0399 & $0.0571 * * *$ & 0.0277 & 0.0283 & 0.00649 \\
\hline & $(0.0175)$ & $(0.0201)$ & $(0.0225)$ & $(0.0346)$ & $(0.0198)$ & $(0.0260)$ & $(0.0191)$ & $(0.0279)$ \\
\hline \multirow[t]{2}{*}{ Year $=1998^{*}$ Mayor $(\mathrm{PSDB}=1)$} & $-0.0765 * * *$ & $-0.127^{* * *}$ & $-0.0511^{* *}$ & $-0.0961 * *$ & 0.00568 & 0.0343 & 0.0239 & 0.0436 \\
\hline & $(0.0191)$ & $(0.0208)$ & $(0.0245)$ & $(0.0389)$ & $(0.0211)$ & $(0.0266)$ & $(0.0200)$ & $(0.0281)$ \\
\hline \multirow[t]{2}{*}{$\mathrm{EV}^{*}$ Mayor $(\mathrm{PSDB}=1)$} & 0.018 & 0.00979 & $0.0637^{* *}$ & 0.0598 & -0.0527 & -0.00552 & $-0.0778^{* *}$ & -0.0323 \\
\hline & $(0.0321)$ & $(0.0445)$ & $(0.0316)$ & $(0.0595)$ & $(0.0334)$ & $(0.0353)$ & $(0.0327)$ & $(0.0383)$ \\
\hline \multirow{2}{*}{$\mathrm{EV}(98)^{*}$ Mayor $(\mathrm{PSDB}=1)$} & -0.0406 & 0.0147 & -0.00296 & 0.0639 & -0.0235 & -0.0487 & 0.00628 & -0.0324 \\
\hline & $(0.0511)$ & $(0.0615)$ & $(0.0659)$ & $(0.0835)$ & $(0.0437)$ & $(0.0434)$ & $(0.0441)$ & $(0.0451)$ \\
\hline \multirow[t]{2}{*}{ Constant } & $0.543^{* * *}$ & $0.669^{* * *}$ & $0.543^{* * *}$ & $0.349^{* * *}$ & -0.0148 & 0.0641 & $-0.0523^{* *}$ & -0.0315 \\
\hline & (0.0389) & $(0.0479)$ & $(0.0366)$ & $(0.1220)$ & $(0.0189)$ & $(0.0624)$ & $(0.0208)$ & $(0.0594)$ \\
\hline \multirow[t]{2}{*}{ Observations } & 2388 & 2388 & 1207 & 1207 & 2388 & 2388 & 2388 & 2388 \\
\hline & Robu & $\begin{array}{l}\text { ndard } \\
.01, * *\end{array}$ & in pare & & & & & \\
\hline
\end{tabular}

(1) Pooled regression; (2) Fixed Effects

Using average years of schooling, percentage of poor people, longevity HDI, inequality (Theil Index), children mortality, house infrastructure (telephone and electricity), percentage of woman, mayor party,mayor vote share on the last election, number of electors (as deviation from the threshold), state/municipality fixed effects, electors age composition (young and elderly), political engagement as controls 
Table 72: Tight election race - Electronic voting impact on PMDB Votes party code votes (over total party code votes)

\begin{tabular}{|c|c|c|c|c|c|c|}
\hline Dep. Var.: PMDB Party Code Vote Share & Gove & nor & Federal & Deputy & State I & eputy \\
\hline Regressions & (1) & (2) & (1) & (2) & (1) & (2) \\
\hline Electronic Voting (EV) & $\begin{array}{c}0.0348 \\
(0.0439)\end{array}$ & & $\begin{array}{c}0.0433^{*} \\
(0.0232)\end{array}$ & & $\begin{array}{c}0.0649 * * * \\
(0.0213)\end{array}$ & \\
\hline Year $=1998$ & $\begin{array}{c}0.127^{* * *} \\
(0.0100)\end{array}$ & $\begin{array}{c}0.116^{* * *} \\
(0.0125)\end{array}$ & $\begin{array}{c}0.0371^{* * *} \\
(0.0055)\end{array}$ & $\begin{array}{c}0.0337^{* * *} \\
(0.0065)\end{array}$ & $\begin{array}{c}0.0355^{* * *} \\
(0.0062)\end{array}$ & $\begin{array}{c}0.0262^{* * *} \\
(0.0074)\end{array}$ \\
\hline EV * Year $=1998[\mathrm{EV}(98)]$ & $\begin{array}{c}-0.00211 \\
(0.1030)\end{array}$ & $\begin{array}{l}0.222 \\
(0.1550)\end{array}$ & $\begin{array}{c}-0.0912^{* * *} \\
(0.0303)\end{array}$ & $\begin{array}{c}-0.0886^{* * *} \\
(0.0328)\end{array}$ & $\begin{array}{c}-0.104^{* * *} \\
(0.0333)\end{array}$ & $\begin{array}{c}-0.112^{* * *} \\
(0.0391)\end{array}$ \\
\hline Poor People $(\%)$ & $\begin{array}{c}-0.0676^{* * *} \\
(0.0117)\end{array}$ & & $\begin{array}{c}-0.0299 * * * \\
(0.0087)\end{array}$ & & $\begin{array}{c}-0.0273^{* * *} \\
(0.0104)\end{array}$ & \\
\hline EV $(98) *$ Poor People (\%) & $\begin{array}{c}-0.0474 \\
(0.0824)\end{array}$ & $\begin{array}{l}-0.14 \\
(0.1160)\end{array}$ & $\begin{array}{c}0.0106 \\
(0.0273)\end{array}$ & $\begin{array}{c}0.00712 \\
(0.0262)\end{array}$ & $\begin{array}{c}0.00512 \\
(0.0292)\end{array}$ & $\begin{array}{c}-0.00127 \\
(0.0328)\end{array}$ \\
\hline EV*Poor People (\%) & $\begin{array}{l}0.0407 \\
(0.0500)\end{array}$ & & $\begin{array}{c}-0.0309 \\
(0.0216)\end{array}$ & & $\begin{array}{c}-0.0183 \\
(0.0207)\end{array}$ & \\
\hline Year $=1998^{*}$ Poor People $(\%)$ & $\begin{array}{c}0.106^{* * *} \\
(0.0161)\end{array}$ & $\begin{array}{c}0.110 * * * \\
(0.0176)\end{array}$ & $\begin{array}{c}0.0674^{* * *} \\
(0.0096)\end{array}$ & $\begin{array}{c}0.0666^{* * *} \\
(0.0096)\end{array}$ & $\begin{array}{c}0.0544^{* * *} \\
(0.0109)\end{array}$ & $\begin{array}{c}0.0549^{* * *} \\
(0.0111)\end{array}$ \\
\hline $\mathrm{EV}(98) *$ Years of study & $\begin{array}{c}-0.0513 \\
(0.0631)\end{array}$ & $\begin{array}{c}-0.136^{*} \\
(0.0722)\end{array}$ & $\begin{array}{c}0.0276 \\
(0.0252)\end{array}$ & $\begin{array}{c}0.0171 \\
(0.0257)\end{array}$ & $\begin{array}{c}0.00249 \\
(0.0262)\end{array}$ & $\begin{array}{c}0.00843 \\
(0.0274)\end{array}$ \\
\hline Mayor $(\mathrm{PMDB}=1)$ & $\begin{array}{c}0.0573^{* * *} \\
(0.0124)\end{array}$ & $\begin{array}{c}0.0516 \text { ** } \\
(0.0218)\end{array}$ & $\begin{array}{c}0.0405^{* * *} \\
(0.0104)\end{array}$ & $\begin{array}{c}0.00967 \\
(0.0128)\end{array}$ & $\begin{array}{c}0.0490 * * * \\
(0.0118)\end{array}$ & $\begin{array}{c}0.0231 \\
(0.0147)\end{array}$ \\
\hline Year $=1998 *$ Mayor $(\mathrm{PMDB}=1)$ & $\begin{array}{c}-0.0376^{* *} \\
(0.0149)\end{array}$ & $\begin{array}{c}-0.0381 \\
(0.0246)\end{array}$ & $\begin{array}{c}-0.00998 \\
(0.0111)\end{array}$ & $\begin{array}{c}-0.0025 \\
(0.0148)\end{array}$ & $\begin{array}{c}-0.00875 \\
(0.0125)\end{array}$ & $\begin{array}{c}-0.00107 \\
(0.0166)\end{array}$ \\
\hline $\mathrm{EV}^{*}$ Mayor $(\mathrm{PMDB}=1)$ & $\begin{array}{c}0.00765 \\
(0.0475)\end{array}$ & $\begin{array}{c}-0.0927^{*} \\
(0.0561)\end{array}$ & $\begin{array}{c}-0.00123 \\
(0.0230)\end{array}$ & $\begin{array}{c}-0.0137 \\
(0.0265)\end{array}$ & $\begin{array}{c}-0.0108 \\
(0.0226)\end{array}$ & $\begin{array}{l}-0.03 \\
(0.0277)\end{array}$ \\
\hline $\mathrm{EV}(98) *$ Mayor $(\mathrm{PMDB}=1)$ & $\begin{array}{c}-0.0115 \\
(0.0821)\end{array}$ & $\begin{array}{l}0.102 \\
(0.0866)\end{array}$ & $\begin{array}{c}-0.0143 \\
(0.0347)\end{array}$ & $\begin{array}{c}-0.00386 \\
(0.0358)\end{array}$ & $\begin{array}{c}-0.0141 \\
(0.0356)\end{array}$ & $\begin{array}{c}0.0285 \\
(0.0352)\end{array}$ \\
\hline Constant & $\begin{array}{c}0.0970 * * * \\
(0.0343)\end{array}$ & $\begin{array}{c}0.527 * * * \\
(0.1350)\end{array}$ & $\begin{array}{c}0.175^{* * *} \\
(0.0309)\end{array}$ & $\begin{array}{c}0.231^{* * *} \\
(0.0588)\end{array}$ & $\begin{array}{c}0.137 * * * \\
(0.0368)\end{array}$ & $\begin{array}{c}0.316^{* * *} \\
(0.0583)\end{array}$ \\
\hline Observations & $\begin{array}{c}1940 \\
\text { tandard } \\
<0.01, * *\end{array}$ & $\begin{array}{r}1940 \\
\text { rs in p } \\
0.05, *\end{array}$ & $\begin{array}{l}\quad 2388 \\
\text { theses } \\
0.1\end{array}$ & 2388 & 2388 & 2388 \\
\hline
\end{tabular}

Using average years of schooling, percentage of poor people, longevity HDI, inequality (Theil Index), children mortality, house infrastructure (telephone and electricity), percentage of woman, mayor party, mayor vote share on the last election, number of electors (as deviation from the threshold), state/municipality fixed effects,electors age composition (young and elderly), political engagement as controls 
Table 73: Tight election race - Electronic voting impact on PFL Votes party code votes (over total party code votes)

\begin{tabular}{|c|c|c|c|c|}
\hline Dep. Var.: PFL Party Code Vote Share & \multicolumn{2}{|c|}{ Federal Deputy } & \multicolumn{2}{|c|}{ State Deputy } \\
\hline Regressions & 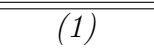 & 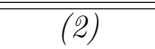 & (1) & (2) \\
\hline Electronic Voting (EV) & $\begin{array}{c}-0.0296 \\
(0.0209)\end{array}$ & & $\begin{array}{c}-0.0373^{*} \\
(0.0198)\end{array}$ & \\
\hline Year $=1998$ & $\begin{array}{c}0.0437^{* * *} \\
(0.0048)\end{array}$ & $\begin{array}{c}0.0349 * * * \\
(0.0057)\end{array}$ & $\begin{array}{c}0.0344^{* * *} \\
(0.0051)\end{array}$ & $\begin{array}{c}0.0309 * * * \\
(0.0056)\end{array}$ \\
\hline $\mathrm{EV} *$ Year $=1998[\mathrm{EV}(98)]$ & $\begin{array}{c}-0.00768 \\
(0.0237)\end{array}$ & $\begin{array}{c}0.0213 \\
(0.0313)\end{array}$ & $\begin{array}{c}0.0276 \\
(0.0260)\end{array}$ & $\begin{array}{c}0.0664^{*} \\
(0.0348)\end{array}$ \\
\hline Poor People (\%) & $\begin{array}{c}-0.0138^{*} \\
(0.0075)\end{array}$ & & $\begin{array}{c}-0.0185^{* *} \\
(0.0089)\end{array}$ & \\
\hline EV $(98)^{*}$ Poor People (\%) & $\begin{array}{c}-0.00281 \\
(0.0209)\end{array}$ & $\begin{array}{c}0.0022 \\
(0.0214)\end{array}$ & $\begin{array}{c}-0.0437^{*} \\
(0.0251)\end{array}$ & $\begin{array}{c}-0.0381^{*} \\
(0.0228)\end{array}$ \\
\hline EV*Poor People (\%) & $\begin{array}{c}0.00434 \\
(0.0211)\end{array}$ & & $\begin{array}{c}0.0221 \\
(0.0210)\end{array}$ & \\
\hline Year $=1998 *$ Poor People $(\%)$ & $\begin{array}{c}0.00721 \\
(0.0096)\end{array}$ & $\begin{array}{c}0.00769 \\
(0.0098)\end{array}$ & $\begin{array}{c}0.00703 \\
(0.0099)\end{array}$ & $\begin{array}{c}0.00538 \\
(0.0098)\end{array}$ \\
\hline $\mathrm{EV}(98) *$ Years of study & $\begin{array}{c}0.0281 \\
(0.0198)\end{array}$ & $\begin{array}{c}0.0203 \\
(0.0210)\end{array}$ & $\begin{array}{c}0.00367 \\
(0.0220)\end{array}$ & $\begin{array}{c}-0.0127 \\
(0.0212)\end{array}$ \\
\hline Mayor $(\mathrm{PFL}=1)$ & $\begin{array}{c}0.0511^{* * *} \\
(0.0107)\end{array}$ & $\begin{array}{c}0.0322^{* *} \\
(0.0149)\end{array}$ & $\begin{array}{c}0.0537^{* * *} \\
(0.0125)\end{array}$ & $\begin{array}{c}0.0424^{* * *} \\
(0.0146)\end{array}$ \\
\hline Year $=1998^{*}$ Mayor $(\mathrm{PFL}=1)$ & $\begin{array}{c}-0.0164 \\
(0.0121)\end{array}$ & $\begin{array}{c}-0.0229 \\
(0.0170)\end{array}$ & $\begin{array}{c}-0.00767 \\
(0.0128)\end{array}$ & $\begin{array}{c}-0.0246 \\
(0.0160)\end{array}$ \\
\hline $\mathrm{EV}^{*}$ Mayor $(\mathrm{PFL}=1)$ & $\begin{array}{c}-0.0418^{*} \\
(0.0219)\end{array}$ & $\begin{array}{l}-0.019 \\
(0.0436)\end{array}$ & $\begin{array}{c}-0.0243 \\
(0.0204)\end{array}$ & $\begin{array}{l}-0.064 \\
(0.0613)\end{array}$ \\
\hline $\mathrm{EV}(98) *$ Mayor $(\mathrm{PFL}=1)$ & $\begin{array}{c}0.00788 \\
(0.0348)\end{array}$ & $\begin{array}{c}0.00634 \\
(0.0515)\end{array}$ & $\begin{array}{c}0.00679 \\
(0.0428)\end{array}$ & $\begin{array}{c}0.0575 \\
(0.0661)\end{array}$ \\
\hline Constant & $\begin{array}{c}0.0970^{* * *} \\
(0.0243) \\
\end{array}$ & $\begin{array}{c}0.242^{* * *} \\
(0.0474) \\
\end{array}$ & $\begin{array}{c}0.0787^{* * *} \\
(0.0227)\end{array}$ & $\begin{array}{c}0.256^{* * *} \\
(0.0509)\end{array}$ \\
\hline Observations & $\begin{array}{c}2388 \\
\text { ors in p } \\
<0.05 \text { * }\end{array}$ & $\begin{array}{l}2388 \\
\text { theses } \\
0.1\end{array}$ & 2388 & 2388 \\
\hline
\end{tabular}

(1) Pooled regression; (2) Fixed Effects

Using average years of schooling, percentage of poor people, longevity HDI, inequality (Theil Index), children mortality, house infrastructure (telephone and electricity), percentage of woman, mayor party, mayor vote share on the last election, number of electors (as deviation from the threshold), state/municipality fixed effects,electors age composition (young and elderly), political engagement as controls 
Table 74: Tight election race - Electronic voting impact on Votes for the Mayor Party

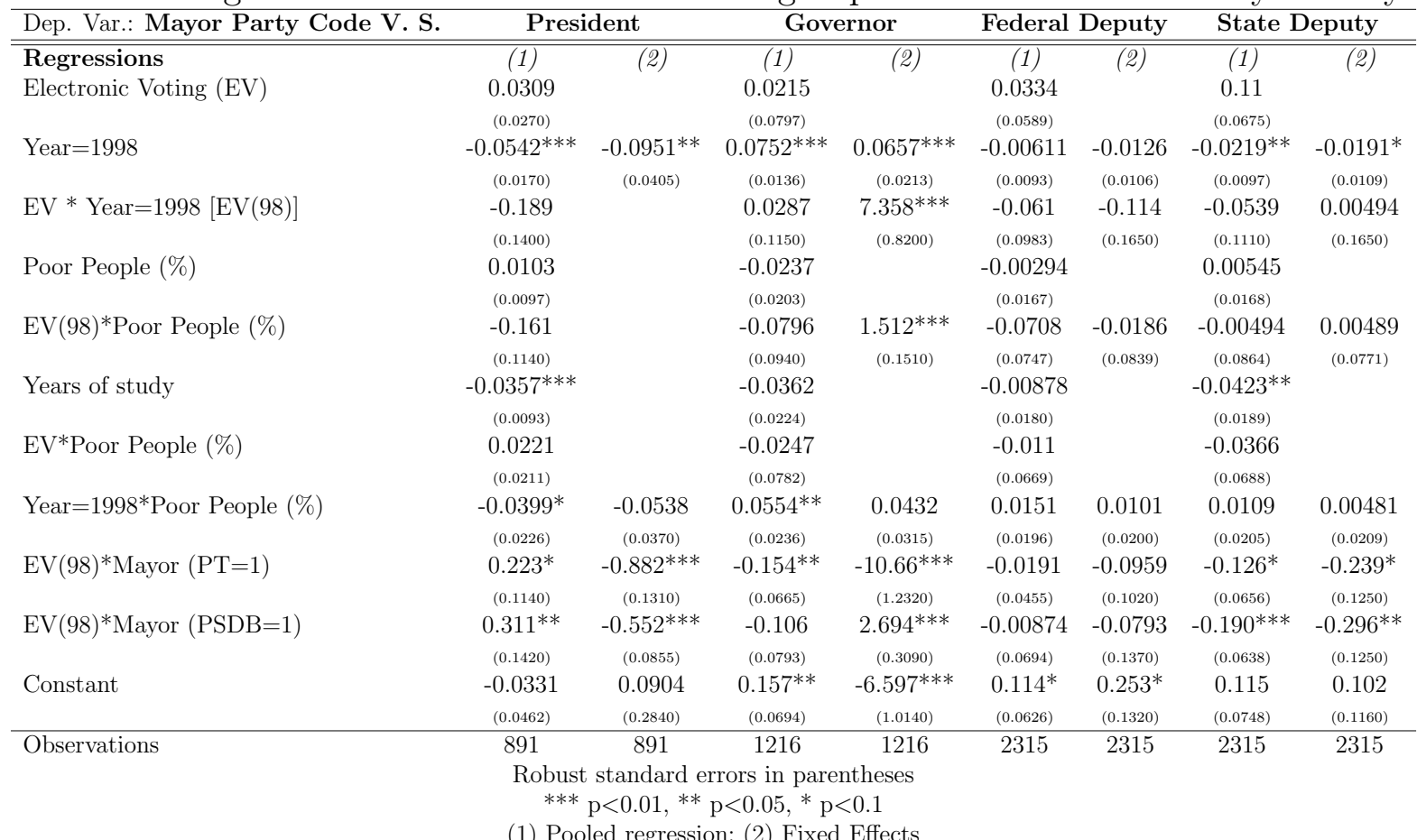

(1) Pooled regression; (2) Fixed Effects

Using average years of schooling, percentage of poor people, longevity HDI, inequality (Theil Index), children mortality, house infrastructure (telephone and electricity), percentage of woman, mayor party,mayor vote share on the last election, number of electors (as deviation from the threshold), state/municipality fixed effects,electors age composition (young and elderly), political engagement as controls 
Table 75: Tight election race - Electronic voting impact on Party Code Votes from the Mayor Party (over total party code votes)

\begin{tabular}{|c|c|c|c|c|}
\hline Dep. Var.: Mayor Party Code V. S. & \multicolumn{2}{|c|}{ Federal Deputy } & \multicolumn{2}{|c|}{ State Deputy } \\
\hline Regressions & 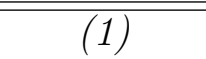 & $\overline{(2)}$ & $\overline{(1)}$ & $\overline{(2)}$ \\
\hline \multirow{2}{*}{ Electronic Voting (EV) } & -0.016 & & -0.0007 & \\
\hline & $(0.0265)$ & & $(0.0397)$ & \\
\hline \multirow[t]{2}{*}{ Year $=1998$} & 0.00802 & 0.00189 & 0.00487 & -0.0014 \\
\hline & $(0.0065)$ & $(0.0079)$ & $(0.0070)$ & $(0.0086)$ \\
\hline \multirow[t]{2}{*}{ EV * Year $=1998[\mathrm{EV}(98)]$} & -0.0313 & -0.0874 & -0.0502 & -0.0663 \\
\hline & $(0.0475)$ & $(0.0666)$ & $(0.0566)$ & $(0.0655)$ \\
\hline \multirow[t]{2}{*}{ Poor People (\%) } & 0.00695 & & 0.00953 & \\
\hline & $(0.0119)$ & & $(0.0135)$ & \\
\hline \multirow[t]{2}{*}{ EV $(98) *$ Poor People (\%) } & -0.0091 & -0.0119 & -0.0183 & -0.0226 \\
\hline & $(0.0386)$ & $(0.0367)$ & $(0.0450)$ & $(0.0406)$ \\
\hline \multirow[t]{2}{*}{ Years of study } & $-0.0469^{* * *}$ & & $-0.0427^{* * *}$ & \\
\hline & $(0.0128)$ & & $(0.0149)$ & \\
\hline \multirow[t]{2}{*}{ EV*Poor People (\%) } & -0.0304 & & -0.0221 & \\
\hline & $(0.0293)$ & & $(0.0354)$ & \\
\hline \multirow{2}{*}{ Year $=1998 *$ Poor People $(\%)$} & 0.00776 & 0.00725 & -0.00255 & 0.00398 \\
\hline & $(0.0140)$ & $\begin{array}{l}(0.0148) \\
0.0527\end{array}$ & $(0.0151)$ & $(0.0160)$ \\
\hline $\mathrm{EV}(98) *$ Mayor $(\mathrm{PT}=1)$ & $\begin{array}{c}-0.0704 \\
(0.0518)\end{array}$ & $\begin{array}{c}-0.0537 \\
(0.0663)\end{array}$ & $\begin{array}{c}-0.0933^{*} \\
(0.0524)\end{array}$ & $\begin{array}{c}-0.0981 \\
(0.0631)\end{array}$ \\
\hline \multirow[t]{2}{*}{$\mathrm{EV}(98)^{*}$ Mayor $(\mathrm{PMDB}=1)$} & $-0.0674^{* *}$ & -0.026 & $-0.0619^{*}$ & -0.0127 \\
\hline & $(0.0331)$ & $(0.0399)$ & $(0.0369)$ & $(0.0441)$ \\
\hline \multirow[t]{2}{*}{$\mathrm{EV}(98) *$ Mayor $(\mathrm{PSDB}=1)$} & -0.0694 & -0.0508 & 0.0225 & 0.0106 \\
\hline & $(0.0434)$ & $(0.0632)$ & $(0.0417)$ & $(0.0601)$ \\
\hline \multirow[t]{2}{*}{ Constant } & $0.0877^{* *}$ & $0.152^{*}$ & $0.104^{* *}$ & $0.236^{* * *}$ \\
\hline & $(0.0375)$ & $(0.0777)$ & $(0.0481)$ & $(0.0876)$ \\
\hline \multirow[t]{2}{*}{ Observations } & 2062 & 2062 & 2010 & 2010 \\
\hline & $\begin{array}{l}\text { rrors in pa } \\
\mathrm{p}<0.05, * \\
\text { on; (2) Fix }\end{array}$ & $\begin{array}{l}\text { ntheses } \\
<0.1 \\
\text { Effects }\end{array}$ & & \\
\hline
\end{tabular}

Using average years of schooling, percentage of poor people, longevity HDI, inequality (Theil Index), children mortality, house infrastructure (telephone and electricity), percentage of woman, mayor party,mayor vote share on the last election, number of electors (as deviation from the threshold), state/municipality fixed effects, electors age composition (young and elderly), political engagement as controls 
Table 76: Tight election race - Electronic voting impact on the probability of choosing the same party for legislative and president offices

\begin{tabular}{|c|c|c|c|c|}
\hline \multirow{2}{*}{$\begin{array}{l}\text { Dep. Var.: Prob. of voting on } \\
\text { Regressions }\end{array}$} & \multicolumn{2}{|c|}{ PT } & \multicolumn{2}{|c|}{ PSDB } \\
\hline & (1) & $\overline{(2)}$ & (1) & $\overline{(2)}$ \\
\hline Electronic Voting (EV) & $\begin{array}{c}-0.00266 \\
(0.0045)\end{array}$ & & $\begin{array}{l}0.0220^{*} \\
(0.0121)\end{array}$ & \\
\hline Year $=1998$ & $\begin{array}{c}0.0000935 \\
(0.0004)\end{array}$ & $\begin{array}{c}0.000822^{* * *} \\
(0.0003)\end{array}$ & $\begin{array}{c}0.0117^{* * *} \\
(0.0023)\end{array}$ & $\begin{array}{c}0.0125^{* * *} \\
(0.0026)\end{array}$ \\
\hline EV * Year $=1998[\mathrm{EV}(98)]$ & $\begin{array}{l}0.00527 \\
(0.0045)\end{array}$ & $\begin{array}{c}0.0025 \\
(0.0036)\end{array}$ & $\begin{array}{l}-0.0163 \\
(0.0174)\end{array}$ & $\begin{array}{l}-0.0302 \\
(0.0194)\end{array}$ \\
\hline EV $(98) *$ Poor People (\%) & $\begin{array}{l}0.00599 \\
(0.0042)\end{array}$ & $\begin{array}{c}0.00833^{* * *} \\
(0.0029)\end{array}$ & $\begin{array}{r}-0.00323 \\
(0.0110)\end{array}$ & $\begin{array}{l}-0.00557 \\
(0.0095)\end{array}$ \\
\hline EV $(98)^{*}$ Years of study & $\begin{array}{c}0.00647^{* * * *} \\
(0.0024)\end{array}$ & $\begin{array}{c}0.00617^{* * *} \\
(0.0019)\end{array}$ & $\begin{array}{l}-0.0163^{*} \\
(0.0097)\end{array}$ & $\begin{array}{c}-0.0210^{* *} \\
(0.0092)\end{array}$ \\
\hline Mayor & $\begin{array}{c}0.0344 \\
(0.0238)\end{array}$ & $\begin{array}{c}0.0036 \\
(0.0035)\end{array}$ & $\begin{array}{l}0.0183^{*} \\
(0.0110)\end{array}$ & $\begin{array}{c}0.0174 \\
(0.0116)\end{array}$ \\
\hline Year $=1998 *$ Mayor & $\begin{array}{c}-0.011 \\
(0.0204)\end{array}$ & $\begin{array}{r}-0.00301 \\
(0.0049)\end{array}$ & $\begin{array}{l}-0.00653 \\
(0.0110)\end{array}$ & $\begin{array}{c}-0.01 \\
(0.0124)\end{array}$ \\
\hline $\mathrm{EV}^{*}$ Mayor & $\begin{array}{l}-0.0292 \\
(0.0245)\end{array}$ & $\begin{array}{c}-0.0135^{* * *} \\
(0.0047)\end{array}$ & $\begin{array}{l}-0.025 \\
(0.0261)\end{array}$ & $\begin{array}{l}-0.0158 \\
(0.0204)\end{array}$ \\
\hline EV(98)*Mayor & $\begin{array}{c}-0.000104 \\
(0.0232)\end{array}$ & $\begin{array}{l}0.00531 \\
(0.0072)\end{array}$ & $\begin{array}{r}-0.00225 \\
(0.0248)\end{array}$ & $\begin{array}{c}0.0102 \\
(0.0191)\end{array}$ \\
\hline Constant & $\begin{array}{c}0.000384 \\
(0.0045)\end{array}$ & $\begin{array}{c}0.00000696 \\
(0.0028)\end{array}$ & $\begin{array}{c}0.0516 \\
(0.0466)\end{array}$ & $\begin{array}{c}0.012 \\
(0.0273)\end{array}$ \\
\hline Observations & $\begin{array}{l}2388 \\
\text { ard err }\end{array}$ & $\begin{array}{l}2388 \\
\text { arenthe } \\
\mathrm{p}<0.1\end{array}$ & 2388 & 2388 \\
\hline
\end{tabular}

(1) Pooled regression; (2) Fixed Effects

Using average years of schooling, percentage of poor people, longevity HDI, inequality (Theil Index), children mortality, house infrastructure (telephone and electricity), percentage of woman, mayor party,mayor vote share on the last election, number of electors (as deviation from the threshold), state/municipality fixed effects, electors age composition (young and elderly), political engagement as controls 
Table 77: Tight election race - Electronic voting impact on the probability of choosing the same party for legislative offices (party code votes)

\begin{tabular}{lcccccc}
\hline Dep. Var.: Prob. of voting on & \multicolumn{2}{c}{ PT } & \multicolumn{2}{c}{ PSDB } & \multicolumn{2}{c}{ PMDB } \\
\hline \hline Regressions & $(1)$ & $(2)$ & $(1)$ & $(2)$ & $(1)$ & $(2)$ \\
Electronic Voting (EV) & 0.0189 & & -0.0419 & & -0.00234 & \\
& $(0.0433)$ & & $(0.0268)$ & & $(0.0181)$ & \\
Year=1998 & $-0.137^{* * *}$ & $-0.129^{* * *}$ & -0.0182 & -0.0251 & -0.0108 & -0.0152 \\
& $(0.0084)$ & $(0.0098)$ & $(0.0131)$ & $(0.0156)$ & $(0.0095)$ & $(0.0110)$ \\
EV * Year=1998 [EV(98)] & -0.0373 & -0.0309 & $0.0761^{* * *}$ & $0.0864^{* *}$ & -0.00429 & -0.00316 \\
& $(0.0518)$ & $(0.0648)$ & $(0.0279)$ & $(0.0338)$ & $(0.0223)$ & $(0.0200)$ \\
EV(98)*Poor People (\%) & 0.041 & 0.0601 & 0.0346 & 0.0132 & 0.00906 & -0.0122 \\
& $(0.0413)$ & $(0.0459)$ & $(0.0295)$ & $(0.0318)$ & $(0.0195)$ & $(0.0188)$ \\
EV(98)*Years of study & 0.02 & 0.0358 & -0.042 & -0.0315 & -0.0126 & -0.0139 \\
& $(0.0367)$ & $(0.0390)$ & $(0.0284)$ & $(0.0318)$ & $(0.0215)$ & $(0.0219)$ \\
Mayor & 0.0111 & -0.0329 & $0.0362^{* *}$ & $0.0758^{* * *}$ & 0.000891 & -0.00739 \\
& $(0.0254)$ & $(0.0309)$ & $(0.0160)$ & $(0.0263)$ & $(0.0150)$ & $(0.0171)$ \\
Year=1998*Mayor & 0.0166 & 0.00621 & -0.00494 & 0.00146 & 0.00764 & 0.00991 \\
& $(0.0163)$ & $(0.0197)$ & $(0.0230)$ & $(0.0317)$ & $(0.0147)$ & $(0.0209)$ \\
EV*Mayor & 0.0128 & -0.00969 & 0.0217 & -0.0118 & 0.00564 & 0.000749 \\
EV(98)*Mayor & $(0.0308)$ & $(0.0378)$ & $(0.0262)$ & $(0.0290)$ & $(0.0171)$ & $(0.0189)$ \\
& -0.0364 & 0.0245 & -0.0174 & 0.014 & -0.0202 & -0.0166 \\
Constant & $(0.0395)$ & $(0.0604)$ & $(0.0336)$ & $(0.0419)$ & $(0.0273)$ & $(0.0263)$ \\
& $0.209^{* * *}$ & $0.152^{* *}$ & 0.0376 & -0.0117 & $-0.113^{* * *}$ & $0.133^{* *}$ \\
Observations & $(0.0556)$ & $(0.0742)$ & $(0.0974)$ & $(0.1050)$ & $(0.0362)$ & $(0.0557)$ \\
& 2388 & 2388 & 2388 & 2388 & 2388 & 2388 \\
& Robust standard errors in parentheses & & &
\end{tabular}

(1) Pooled regression; (2) Fixed Effects

Using average years of schooling, percentage of poor people, longevity HDI, inequality (Theil Index), children mortality, house infrastructure (telephone and electricity), percentage of woman, mayor party,mayor vote share on the last election, number of electors (as deviation from the threshold), state/municipality fixed effects,electors age composition (young and elderly), political engagement as controls 
Table 78: Tight election race - Electronic voting impact on the odds of voting for PSDB deputy over PSDB president

\begin{tabular}{|c|c|c|c|c|}
\hline \multirow{2}{*}{$\begin{array}{l}\text { Dep. Var.: Odds of voting for: } \\
\text { Regressions }\end{array}$} & \multicolumn{2}{|c|}{ Federal Deputy } & \multicolumn{2}{|c|}{ State Deputy } \\
\hline & (1) & (2) & (1) & (2) \\
\hline \multirow[t]{2}{*}{ Electronic Voting (EV) } & 0.0908 & & 0.0198 & \\
\hline & $(0.0594)$ & & $(0.0847)$ & \\
\hline \multirow[t]{2}{*}{ Year $=1998$} & $0.127^{* * *}$ & $0.121^{* * *}$ & $0.131^{* * *}$ & $0.147^{* * *}$ \\
\hline & $(0.0120)$ & $(0.0134)$ & $(0.0128)$ & $(0.0138)$ \\
\hline \multirow[t]{2}{*}{$\mathrm{EV}^{*}$ Year $=1998[\mathrm{EV}(98)]$} & -0.0711 & -0.0363 & -0.00267 & -0.0126 \\
\hline & $(0.1040)$ & $(0.1450)$ & $(0.0962)$ & $(0.1070)$ \\
\hline \multirow[t]{2}{*}{ Poor People (\%) } & 0.00845 & & $0.0366^{*}$ & \\
\hline & $(0.0177)$ & & $(0.0206)$ & \\
\hline \multirow[t]{2}{*}{ EV $(98) *$ Poor People $(\%)$} & 0.0304 & 0.123 & 0.0203 & 0.0411 \\
\hline & $(0.0888)$ & $(0.0965)$ & $(0.0863)$ & $(0.0851)$ \\
\hline \multirow[t]{2}{*}{ Years of study } & $0.0721^{* * *}$ & & 0.0232 & \\
\hline & $(0.0180)$ & & $(0.0182)$ & \\
\hline \multirow[t]{2}{*}{ EV*Poor People (\%) } & $-0.116^{* * *}$ & & -0.146 & \\
\hline & $(0.0438)$ & & $(0.1070)$ & \\
\hline \multirow[t]{2}{*}{ Year $=1998 *$ Poor People $(\%)$} & $0.0407^{*}$ & $0.0378^{*}$ & 0.0267 & 0.0201 \\
\hline & $(0.0228)$ & $(0.0227)$ & $(0.0231)$ & $(0.0232)$ \\
\hline \multirow[t]{2}{*}{ Mayor $(\mathrm{PSDB}=1)$} & $-0.106^{* *}$ & $-0.159^{* *}$ & -0.0252 & -0.101 \\
\hline & $(0.0470)$ & $(0.0783)$ & $(0.0359)$ & $(0.0731)$ \\
\hline \multirow[t]{2}{*}{ Year $=1998^{*}$ Mayor $(\mathrm{PSDB}=1)$} & $0.215^{* * *}$ & $0.283^{* * *}$ & $0.163^{* * *}$ & $0.213^{* * *}$ \\
\hline & $(0.0581)$ & $(0.0821)$ & $(0.0456)$ & $(0.0752)$ \\
\hline \multirow[t]{2}{*}{$\mathrm{EV}^{*}$ Mayor $(\mathrm{PSDB}=1)$} & -0.0237 & -0.256 & -0.034 & 0.00834 \\
\hline & $(0.1090)$ & $(0.1690)$ & $(0.1620)$ & $(0.1150)$ \\
\hline \multirow[t]{2}{*}{$\mathrm{EV}(98)^{*}$ Mayor $(\mathrm{PSDB}=1)$} & 0.0171 & 0.0561 & -0.167 & -0.221 \\
\hline & $(0.1680)$ & $(0.2070)$ & $(0.1630)$ & $(0.1370)$ \\
\hline \multirow[t]{2}{*}{ Constant } & 0.0307 & 0.222 & -0.0335 & -0.024 \\
\hline & $(0.0455)$ & $(0.1620)$ & $(0.0401)$ & $(0.1450)$ \\
\hline Observations & 2388 & 2388 & 2388 & 2388 \\
\hline
\end{tabular}

(1) Pooled regression; (2) Fixed Effects

Using average years of schooling, percentage of poor people, longevity HDI, inequality (Theil Index), children mortality, house infrastructure (telephone and electricity), percentage of woman, mayor party,mayor vote share on the last election, number of electors (as deviation from the threshold), state/municipality fixed effects, electors age composition (young and elderly), political engagement as controls 
Table 79: Tight election race - Electronic voting impact on the odds of voting for PSDB deputy (Party Code) over PSDB president

\begin{tabular}{|c|c|c|c|c|}
\hline \multirow{2}{*}{$\begin{array}{l}\text { Dep. Var.: Odds of voting for: } \\
\text { Regressions }\end{array}$} & \multicolumn{2}{|c|}{ Federal Deputy } & \multicolumn{2}{|c|}{ State Deputy } \\
\hline & (1) & (2) & (1) & (2) \\
\hline \multirow[t]{2}{*}{ Electronic Voting (EV) } & 0.0209 & & 0.0365 & \\
\hline & $(0.0403)$ & & $(0.0426)$ & \\
\hline \multirow[t]{2}{*}{ Year $=1998$} & $0.243^{* * *}$ & $0.239 * * *$ & $0.220^{* * *}$ & $0.221^{* * *}$ \\
\hline & $(0.0092)$ & $(0.0107)$ & $(0.0088)$ & $(0.0107)$ \\
\hline \multirow{2}{*}{$\mathrm{EV} *$ Year $=1998[\mathrm{EV}(98)]$} & $-0.239 * * *$ & $-0.157^{* *}$ & -0.0221 & 0.0472 \\
\hline & $(0.0553)$ & $(0.0704)$ & $(0.0559)$ & $(0.0762)$ \\
\hline \multirow[t]{2}{*}{ Poor People $(\%)$} & -0.0134 & & -0.00933 & \\
\hline & $(0.0127)$ & & $(0.0122)$ & \\
\hline \multirow[t]{2}{*}{ EV $(98) *$ Poor People $(\%)$} & 0.0226 & 0.0358 & $0.144^{* *}$ & $0.154^{* *}$ \\
\hline & $(0.0536)$ & $(0.0540)$ & $(0.0605)$ & $(0.0613)$ \\
\hline \multirow[t]{2}{*}{ Years of study } & 0.012 & & 0.000138 & \\
\hline & $(0.0134)$ & & $(0.0130)$ & \\
\hline \multirow[t]{2}{*}{ EV*Poor People (\%) } & -0.0459 & & -0.0411 & \\
\hline & $(0.0445)$ & & $(0.0455)$ & \\
\hline \multirow{2}{*}{ Year $=1998^{*}$ Poor People $(\%)$} & $0.0503^{* * *}$ & $0.0531^{* * *}$ & $0.0481^{* * *}$ & $0.0486 * * *$ \\
\hline & $(0.0180)$ & $(0.0183)$ & $(0.0167)$ & $(0.0166)$ \\
\hline \multirow[t]{2}{*}{ Mayor $(\mathrm{PSDB}=1)$} & -0.0178 & $-0.107^{* *}$ & -0.0452 & $-0.115^{* *}$ \\
\hline & $(0.0323)$ & $(0.0520)$ & $(0.0304)$ & $(0.0469)$ \\
\hline \multirow[t]{2}{*}{ Year $=1998^{*}$ Mayor $(\mathrm{PSDB}=1)$} & $0.150^{* * *}$ & $0.258^{* * *} *$ & $0.156^{* * *}$ & $0.242^{* * *}$ \\
\hline & $(0.0361)$ & $(0.0533)$ & $(0.0339)$ & $(0.0472)$ \\
\hline \multirow[t]{2}{*}{$\mathrm{EV}^{*}$ Mayor $(\mathrm{PSDB}=1)$} & -0.0735 & 0.0421 & -0.116 & -0.101 \\
\hline & $(0.0748)$ & $(0.0790)$ & $(0.0731)$ & $(0.1050)$ \\
\hline \multirow[t]{2}{*}{$\mathrm{EV}(98) *$ Mayor $(\mathrm{PSDB}=1)$} & -0.0489 & -0.163 & 0.0296 & -0.0165 \\
\hline & $(0.0965)$ & $(0.1030)$ & $(0.1050)$ & $(0.1390)$ \\
\hline \multirow[t]{2}{*}{ Constant } & 0.009 & 0.05 & $-0.0470^{*}$ & -0.109 \\
\hline & $(0.0307)$ & $(0.1220)$ & $(0.0281)$ & $(0.1280)$ \\
\hline Observations & 2388 & 2388 & 2388 & 2388 \\
\hline
\end{tabular}

Robust standard errors in parentheses

$$
\text { *** } \mathrm{p}<0.01, * * \mathrm{p}<0.05, * \mathrm{p}<0.1
$$

(1) Pooled regression; (2) Fixed Effects

Using average years of schooling, percentage of poor people, longevity HDI, inequality (Theil Index), children mortality, house infrastructure (telephone and electricity), percentage of woman, mayor party, mayor vote share on the last election, number of electors (as deviation from the threshold), state/municipality fixed effects, electors age composition (young and elderly), political engagement as controls 
Table 80: Tight election race - Electronic voting impact on the odds of voting for PT deputy over PT president

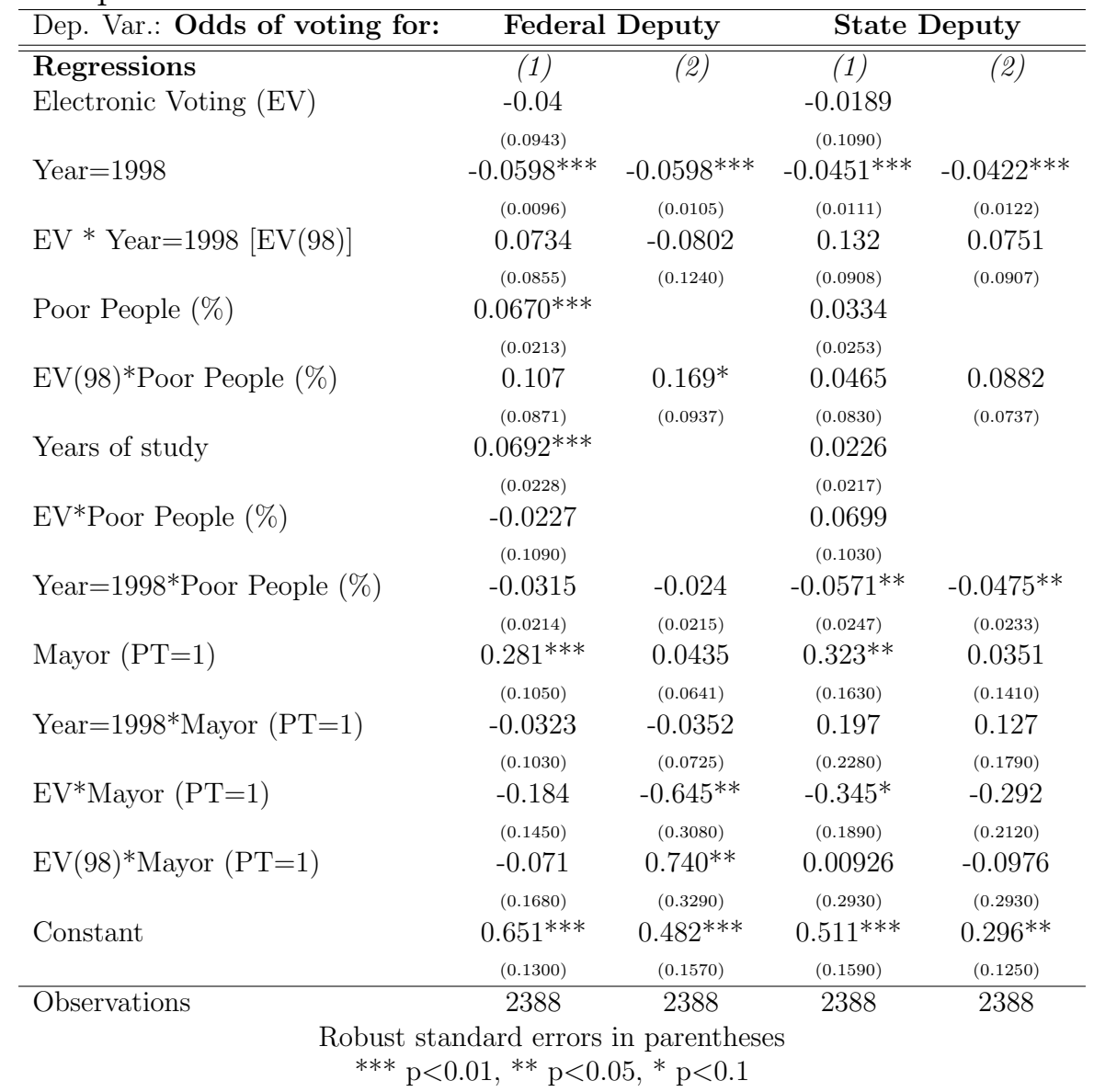

(1) Pooled regression; (2) Fixed Effects

Using average years of schooling, percentage of poor people, longevity HDI, inequality (Theil Index), children mortality, house infrastructure (telephone and electricity), percentage of woman, mayor party, mayor vote share on the last election, number of electors (as deviation from the threshold), state/municipality fixed effects,electors age composition (young and elderly), political engagement as controls

\section{D.3 Results using 2002 election data}


Table 81: Tight election race - Electronic voting impact on the odds of voting for PT deputy (Party Code) over PT president

\begin{tabular}{|c|c|c|c|c|}
\hline \multirow{2}{*}{$\begin{array}{l}\text { Dep. Var.: Odds of voting for: } \\
\text { Regressions }\end{array}$} & \multicolumn{2}{|c|}{ Federal Deputy } & \multicolumn{2}{|c|}{ State Deputy } \\
\hline & (1) & (2) & (1) & (2) \\
\hline \multirow[t]{2}{*}{ Electronic Voting (EV) } & $-0.244^{*}$ & & $-0.358 * *$ & \\
\hline & $(0.1420)$ & & $(0.1770)$ & \\
\hline \multirow{2}{*}{ Year $=1998$} & $-1.259 * * *$ & $-1.280^{* * *}$ & $-1.268^{* * *}$ & $-1.287^{* * *}$ \\
\hline & $(0.0428)$ & $(0.0492)$ & $(0.0485)$ & $(0.0589)$ \\
\hline \multirow[t]{2}{*}{$\mathrm{EV} *$ Year $=1998[\mathrm{EV}(98)]$} & 0.182 & -0.0511 & 0.112 & -0.37 \\
\hline & $(0.1940)$ & $(0.2640)$ & $(0.2180)$ & $(0.3450)$ \\
\hline \multirow[t]{2}{*}{ Poor People (\%) } & $-0.291^{* *}$ & & $-0.197^{*}$ & \\
\hline & $(0.1280)$ & & $(0.1170)$ & \\
\hline \multirow[t]{2}{*}{ EV $(98) *$ Poor People $(\%)$} & -0.175 & 0.103 & 0.137 & $0.494^{*}$ \\
\hline & $(0.2210)$ & $(0.2340)$ & $(0.2600)$ & $(0.2680)$ \\
\hline \multirow[t]{2}{*}{ Years of study } & -0.108 & & -0.0755 & \\
\hline & $(0.0862)$ & & $(0.1140)$ & \\
\hline \multirow[t]{2}{*}{ EV*Poor People (\%) } & 0.218 & & 0.0259 & \\
\hline & $(0.1820)$ & & $(0.2190)$ & \\
\hline \multirow[t]{2}{*}{ Year $=1998^{*}$ Poor People $(\%)$} & 0.151 & 0.128 & 0.0894 & 0.0816 \\
\hline & $(0.1070)$ & $(0.1030)$ & $(0.1100)$ & $(0.1100)$ \\
\hline \multirow[t]{2}{*}{ Mayor $(\mathrm{PT}=1)$} & -0.0166 & -0.149 & 0.216 & 0.0715 \\
\hline & $(0.1010)$ & $(0.1810)$ & $(0.1470)$ & $(0.2270)$ \\
\hline \multirow[t]{2}{*}{ Year $=1998^{*}$ Mayor $(\mathrm{PT}=1)$} & 0.147 & $0.645^{* * *}$ & -0.103 & 0.428 \\
\hline & $(0.1250)$ & $(0.2360)$ & $(0.1710)$ & $(0.2890)$ \\
\hline \multirow[t]{2}{*}{$\mathrm{EV}^{*}$ Mayor $(\mathrm{PT}=1)$} & 0.0213 & -0.172 & -0.307 & -0.556 \\
\hline & $(0.2950)$ & $(0.3670)$ & $(0.2740)$ & $(0.3930)$ \\
\hline \multirow[t]{2}{*}{$\mathrm{EV}(98) *$ Mayor $(\mathrm{PT}=1)$} & -0.158 & 0.0947 & 0.191 & 0.768 \\
\hline & $(0.3900)$ & $(0.4820)$ & $(0.4180)$ & $(0.5270)$ \\
\hline \multirow[t]{2}{*}{ Constant } & $1.937^{* * *}$ & $2.719^{* * *}$ & $2.017^{* * *}$ & $2.232^{* * *}$ \\
\hline & $(0.2290)$ & $(0.4330)$ & $(0.1830)$ & $(0.5230)$ \\
\hline Observations & 2388 & 2388 & 2388 & 2388 \\
\hline
\end{tabular}

(1) Pooled regression; (2) Fixed Effects

Using average years of schooling, percentage of poor people, longevity HDI, inequality (Theil Index), children mortality, house infrastructure (telephone and electricity), percentage of woman, mayor party,mayor vote share on the last election, number of electors (as deviation from the threshold), state/municipality fixed effects,electors age composition (young and elderly), political engagement as controls 
Table 82: Placebo (2002) - Electronic voting impact on Invalid Votes

\begin{tabular}{|c|c|c|c|c|c|c|c|c|}
\hline Dep. Var.: Invalid & \multicolumn{2}{|c|}{ President } & \multicolumn{2}{|c|}{ Governor } & \multicolumn{2}{|c|}{ Federal Deputy } & \multicolumn{2}{|c|}{ State Deputy } \\
\hline Regressions & (1) & (2) & (1) & (2) & (1) & (2) & (1) & (2) \\
\hline Electronic Voting (EV) & $\begin{array}{c}-0.0334^{* * *} \\
(0.0064)\end{array}$ & & $\begin{array}{c}-0.0942^{* * *} \\
(0.0085)\end{array}$ & & $\begin{array}{c}-0.224^{* * *} \\
(0.0068)\end{array}$ & & $\begin{array}{c}-0.162^{* * *} \\
(0.0053)\end{array}$ & \\
\hline Year $=2002$ & $\begin{array}{c}-0.0822^{* * *} \\
(0.0006)\end{array}$ & $\begin{array}{c}-0.0824^{* * *} \\
(0.0006)\end{array}$ & $\begin{array}{c}-0.136^{* * *} \\
(0.0010)\end{array}$ & $\begin{array}{c}-0.136^{* * *} \\
(0.0011)\end{array}$ & $\begin{array}{c}-0.236^{* * *} \\
(0.0010)\end{array}$ & $\begin{array}{c}-0.236^{* * *} \\
(0.0010)\end{array}$ & $\begin{array}{c}-0.176^{* * *} \\
(0.0009)\end{array}$ & $\begin{array}{c}-0.176^{* * *} \\
(0.0010)\end{array}$ \\
\hline $\mathrm{EV} * \mathrm{Year}=2002[\mathrm{EV}(02)]$ & $\begin{array}{c}0.00774 \\
(0.0074)\end{array}$ & $\begin{array}{c}0.0167^{* *} \\
(0.0078)\end{array}$ & $\begin{array}{c}0.0804^{* * *} \\
(0.0091)\end{array}$ & $\begin{array}{c}0.0678^{* * *} \\
(0.0106)\end{array}$ & $\begin{array}{c}0.218^{* * *} \\
(0.0068)\end{array}$ & $\begin{array}{c}0.213^{* * *} \\
(0.0072)\end{array}$ & $\begin{array}{c}0.161^{* * *} \\
(0.0056)\end{array}$ & $\begin{array}{c}0.152^{* * *} \\
(0.0063)\end{array}$ \\
\hline Poor People (\%) & $\begin{array}{c}0.00317^{* *} \\
(0.0015)\end{array}$ & & $\begin{array}{c}0.00033 \\
(0.0020)\end{array}$ & & $\begin{array}{c}-0.0142^{* * *} \\
(0.0026)\end{array}$ & & $\begin{array}{c}-0.0206^{* * *} \\
(0.0024)\end{array}$ & \\
\hline EV $(02) *$ Poor People $(\%)$ & $\begin{array}{c}-0.00148 \\
(0.0048)\end{array}$ & $\begin{array}{c}0.000495 \\
(0.0051)\end{array}$ & $\begin{array}{c}-0.0130^{* *} \\
(0.0065)\end{array}$ & $\begin{array}{c}-0.00668 \\
(0.0065)\end{array}$ & $\begin{array}{c}-0.0100^{* *} \\
(0.0046)\end{array}$ & $\begin{array}{c}-0.0132^{* * *} \\
(0.0048)\end{array}$ & $\begin{array}{c}-0.0224^{* * *} \\
(0.0044)\end{array}$ & $\begin{array}{c}-0.0185^{* * *} \\
(0.0045)\end{array}$ \\
\hline EV*Poor People (\%) & $\begin{array}{c}0.00163 \\
(0.0047)\end{array}$ & & $\begin{array}{c}0.00684 \\
(0.0063)\end{array}$ & & $\begin{array}{c}0.0141^{* * *} \\
(0.0055)\end{array}$ & & $\begin{array}{c}0.0269^{* * *} \\
(0.0047)\end{array}$ & \\
\hline Year $=2002 *$ Poor People $(\%)$ & $\begin{array}{c}0.00111 \\
(0.0013)\end{array}$ & $\begin{array}{c}0.0000901 \\
(0.0013)\end{array}$ & $\begin{array}{c}-0.00519^{* *} \\
(0.0021)\end{array}$ & $\begin{array}{c}-0.00654^{* * *} \\
(0.0021)\end{array}$ & $\begin{array}{c}0.0206^{* * *} \\
(0.0023)\end{array}$ & $\begin{array}{c}0.0169^{* * *} \\
(0.0022)\end{array}$ & $\begin{array}{c}0.0276^{* * *} \\
(0.0023)\end{array}$ & $\begin{array}{c}0.0226^{* * *} \\
(0.0022)\end{array}$ \\
\hline Years of study & $\begin{array}{c}-0.0382^{* * * *} \\
(0.0016)\end{array}$ & & $\begin{array}{c}-0.0411^{* * *} \\
(0.0022)\end{array}$ & & $\begin{array}{c}-0.0150^{* * *} \\
(0.0027)\end{array}$ & & $\begin{array}{c}-0.0272^{* * *} \\
(0.0026)\end{array}$ & \\
\hline EV $(02)^{*}$ Years of study & $\begin{array}{c}-0.00574 \\
(0.0039)\end{array}$ & $\begin{array}{c}0.00108 \\
(0.0041)\end{array}$ & $\begin{array}{c}-0.0210^{* * *} \\
(0.0060)\end{array}$ & $\begin{array}{c}-0.0193^{* * *} \\
(0.0059)\end{array}$ & $\begin{array}{c}-0.0193^{* * *} \\
(0.0045)\end{array}$ & $\begin{array}{c}-0.0153^{* * *} \\
(0.0050)\end{array}$ & $\begin{array}{c}-0.0263^{* * *} \\
(0.0042)\end{array}$ & $\begin{array}{c}-0.0249^{* * *} \\
(0.0046)\end{array}$ \\
\hline $\mathrm{EV}^{*}$ Years of study & $\begin{array}{c}0.0156^{* * *} \\
(0.0037)\end{array}$ & & $\begin{array}{c}0.0205^{* * *} \\
(0.0060)\end{array}$ & & $\begin{array}{c}0.0111^{* *} \\
(0.0054)\end{array}$ & & $\begin{array}{c}0.0252^{* * *} \\
(0.0044)\end{array}$ & \\
\hline Year $=2002 *$ Years of study & $\begin{array}{c}0.0104^{* * *} \\
(0.0015)\end{array}$ & $\begin{array}{c}0.0103^{* * *} \\
(0.0015)\end{array}$ & $\begin{array}{c}0.0177^{* * *} \\
(0.0025)\end{array}$ & $\begin{array}{c}0.0173^{* * *} \\
(0.0026)\end{array}$ & $\begin{array}{c}0.0171^{* * *} \\
(0.0024)\end{array}$ & $\begin{array}{c}0.0176^{* * *} \\
(0.0024)\end{array}$ & $\begin{array}{c}0.0276^{* * *} \\
(0.0024)\end{array}$ & $\begin{array}{c}0.0288^{* * *} \\
(0.0023)\end{array}$ \\
\hline Constant & $\begin{array}{c}0.226^{* * *} \\
(0.0056) \\
\end{array}$ & $\begin{array}{c}0.215^{* * *} \\
(0.0067)\end{array}$ & $\begin{array}{c}0.278^{* * *} \\
(0.0060)\end{array}$ & $\begin{array}{c}0.260^{* * *} \\
(0.0121)\end{array}$ & $\begin{array}{c}0.303^{* * *} \\
(0.0060)\end{array}$ & $\begin{array}{c}0.241^{* * *} \\
(0.0105)\end{array}$ & $\begin{array}{c}0.204^{* * *} \\
(0.0044)\end{array}$ & $\begin{array}{c}0.196^{* * *} \\
(0.0108) \\
\end{array}$ \\
\hline Observations & 10358 & $\begin{array}{c}10377 \\
\text { Robust } \\
* * * \\
\text { (1) Pool }\end{array}$ & $\begin{array}{c}10358 \\
\text { andard er } \\
0.01,{ }^{* *} \\
\text { regressio }\end{array}$ & $\begin{array}{c}10377 \\
\text { in parent } \\
.05,{ }^{*} \mathrm{p}<0 \\
\text { 2) Fixed }\end{array}$ & $\begin{array}{l}10358 \\
\text { es }\end{array}$ & 10377 & 10358 & 10377 \\
\hline
\end{tabular}

Using average years of schooling, percentage of poor people, longevity HDI, inequality (Theil Index), children mortality, house infrastructure (telephone and electricity), percentage of woman, mayor party,mayor vote share on the last election, number of electors (as deviation from the threshold), state/municipality fixed effects, electors age composition (young and elderly), political engagement as controls 
Table 83: Placebo (2002) - Electronic voting impact on Blank Votes

\begin{tabular}{|c|c|c|c|c|c|c|c|c|}
\hline Dep. Var.: Blank & Pres & dent & Gove & rnor & Federal & Deputy & State & Deputy \\
\hline $\begin{array}{l}\text { Regressions } \\
\text { Electronic Voting (EV) }\end{array}$ & $\begin{array}{c}(1) \\
-0.0907^{* * * *} \\
(0.0035)\end{array}$ & (2) & $\begin{array}{c}(1) \\
-0.170^{* * *} \\
(0.0054)\end{array}$ & (2) & $\begin{array}{c}(1) \\
-0.0921^{* * *} \\
(0.0046)\end{array}$ & (2) & $\begin{array}{c}(1) \\
-0.0606^{* * *} \\
(0.0032)\end{array}$ & (2) \\
\hline Year $=2002$ & $\begin{array}{c}-0.105^{* * *} \\
(0.0005)\end{array}$ & $\begin{array}{c}-0.105^{* * *} \\
(0.0005)\end{array}$ & $\begin{array}{c}-0.179^{* * *} \\
(0.0009)\end{array}$ & $\begin{array}{c}-0.179^{* * *} \\
(0.0010)\end{array}$ & $\begin{array}{c}-0.102^{* * *} \\
(0.0006)\end{array}$ & $\begin{array}{c}-0.101^{* * *} \\
(0.0006)\end{array}$ & $\begin{array}{c}-0.0641^{* * *} \\
(0.0005)\end{array}$ & $\begin{array}{c}-0.0639^{* * *} \\
(0.0005)\end{array}$ \\
\hline $\mathrm{EV} *$ Year $=2002[\mathrm{EV}(02)]$ & $\begin{array}{c}0.0914^{* * *} \\
(0.0029)\end{array}$ & $\begin{array}{c}0.0984^{* * *} \\
(0.0030)\end{array}$ & $\begin{array}{c}0.171^{* * *} \\
(0.0043)\end{array}$ & $\begin{array}{c}0.168^{* * *} \\
(0.0041)\end{array}$ & $\begin{array}{c}0.0871^{* * *} \\
(0.0042)\end{array}$ & $\begin{array}{c}0.0931 * * * \\
(0.0042)\end{array}$ & $\begin{array}{c}0.0588^{* * *} \\
(0.0031)\end{array}$ & $\begin{array}{c}0.0614^{* * *} \\
(0.0038)\end{array}$ \\
\hline Poor People (\%) & $\begin{array}{c}0.00686^{* * *} \\
(0.0011)\end{array}$ & & $\begin{array}{c}0.00641^{* * *} \\
(0.0017)\end{array}$ & & $\begin{array}{c}0.00282^{*} \\
(0.0016)\end{array}$ & & $\begin{array}{c}-0.00222^{*} \\
(0.0013)\end{array}$ & \\
\hline $\begin{array}{l}\text { EV }(02)^{*} \text { Poor People }(\%) \\
\text { EV }^{*} \text { Poor People }(\%)\end{array}$ & $\begin{array}{c}0.00979 * * * \\
(0.0021) \\
0.0000954 \\
(0.0027)\end{array}$ & $\begin{array}{c}0.00859^{* * *} \\
(0.0021)\end{array}$ & $\begin{array}{c}0.0171^{* * *} \\
(0.0031) \\
-0.0168^{* * *} \\
(0.0039)\end{array}$ & $\begin{array}{c}0.0198 * * * \\
(0.0029)\end{array}$ & $\begin{array}{c}0.0168^{* * *} \\
(0.0034) \\
-0.0157^{* * *} \\
(0.0037)\end{array}$ & $\begin{array}{c}0.0126^{* * *} \\
\quad(0.0032)\end{array}$ & $\begin{array}{c}0.00825^{* * *} \\
(0.0029) \\
-0.00723^{* *} \\
(0.0029)\end{array}$ & $\begin{array}{c}0.00904^{* * *} \\
(0.0029)\end{array}$ \\
\hline $\begin{array}{l}\text { Year }=2002 * \text { Poor People }(\%) \\
\text { Years of study }\end{array}$ & $\begin{array}{c}-0.00759^{* * *} \\
(0.0010) \\
-0.0289^{* * *} \\
(0.0012)\end{array}$ & $\begin{array}{c}-0.00716^{* * * *} \\
(0.0010)\end{array}$ & $\begin{array}{c}-0.0167^{* * *} \\
(0.0019) \\
-0.0413^{* * *} \\
(0.0019)\end{array}$ & $\begin{array}{c}-0.0175^{* * *} \\
(0.0020)\end{array}$ & $\begin{array}{c}-0.00652^{* * *} \\
(0.0013) \\
-0.00922^{* * *} \\
(0.0016)\end{array}$ & $\begin{array}{c}-0.00791^{* * * *} \\
(0.0013)\end{array}$ & $\begin{array}{c}-0.00195^{*} \\
(0.0012) \\
-0.0168^{* * *} \\
(0.0013)\end{array}$ & $\begin{array}{c}-0.00442^{* * *} \\
(0.0012)\end{array}$ \\
\hline $\begin{array}{l}\text { EV }(02)^{*} \text { Years of study } \\
\text { EV*Years of study }\end{array}$ & $\begin{array}{c}-0.0275^{* * *} \\
(0.0020) \\
0.0298^{* * *} \\
(0.0025)\end{array}$ & $\begin{array}{c}-0.0273^{* * *} \\
(0.0020)\end{array}$ & $\begin{array}{c}-0.0432^{* * *} \\
(0.0030) \\
0.0376^{* * *} \\
(0.0040)\end{array}$ & $\begin{array}{c}-0.0383^{* * *} \\
(0.0033)\end{array}$ & $\begin{array}{c}-0.00943^{* * *} \\
(0.0028) \\
0.00182 \\
(0.0035)\end{array}$ & $\begin{array}{c}-0.00699^{* *} \\
(0.0030)\end{array}$ & $\begin{array}{c}-0.0167^{* * *} \\
(0.0024) \\
0.0120^{* * *} \\
(0.0027)\end{array}$ & $\begin{array}{c}-0.0157^{* * *} \\
(0.0027)\end{array}$ \\
\hline Year $=2002 *$ Years of study & $\begin{array}{c}0.0256^{* * * *} \\
(0.0012)\end{array}$ & $\begin{array}{c}0.0257^{* * *} \\
(0.0012)\end{array}$ & $\begin{array}{c}0.0409^{* * *} \\
(0.0023)\end{array}$ & $\begin{array}{c}0.0404^{* * * *} \\
(0.0024)\end{array}$ & $\begin{array}{c}0.00641^{* * *} \\
(0.0014)\end{array}$ & $\begin{array}{c}0.00723^{* * *} \\
(0.0014)\end{array}$ & $\begin{array}{c}0.0146^{* * *} \\
(0.0012)\end{array}$ & $\begin{array}{c}0.0159^{* * *} \\
(0.0012)\end{array}$ \\
\hline Constant & $\begin{array}{c}0.132^{* * * *} \\
(0.0033) \\
\end{array}$ & $\begin{array}{c}0.147^{* * * *} \\
(0.0049)\end{array}$ & $\begin{array}{c}0.210^{* * * *} \\
(0.0049)\end{array}$ & $\begin{array}{c}0.192^{* * * *} \\
(0.0096)\end{array}$ & $\begin{array}{c}0.138^{* * * *} \\
(0.0032)\end{array}$ & $\begin{array}{c}0.122^{* * * *} \\
(0.0061) \\
\end{array}$ & $\begin{array}{c}0.0785^{* * *} \\
(0.0025)\end{array}$ & $\begin{array}{c}0.0880^{* * * *} \\
(0.0054)\end{array}$ \\
\hline Observations & 10358 & $\begin{array}{r}10377 \\
\text { Roby } \\
* *\end{array}$ & $\begin{array}{l}10358 \\
\text { ndard e } \\
01 * *\end{array}$ & $\begin{array}{l}10377 \\
\text { in pare }\end{array}$ & 10358 & 10377 & 10358 & 10377 \\
\hline
\end{tabular}

(1) Pooled regression; (2) Fixed Effects

Using average years of schooling, percentage of poor people, longevity HDI, inequality (Theil Index), children mortality, house infrastructure (telephone and electricity), percentage of woman, mayor party, mayor vote share on the last election, number of electors (as deviation from the threshold), state/municipality fixed effects, electors age composition (young and elderly), political engagement as controls 
Table 84: Placebo (2002) - Electronic voting impact on Spoiled Votes

\begin{tabular}{|c|c|c|c|c|c|c|c|c|}
\hline Dep. Var.: Spoiled & Pres & dent & Gove & rnor & Federal & Deputy & State & Deputy \\
\hline $\begin{array}{l}\text { Regressions } \\
\text { Electronic Voting (EV) }\end{array}$ & $\begin{array}{c}(1) \\
0.0572^{* * *} \\
(0.0060)\end{array}$ & (2) & $\begin{array}{c}(1) \\
0.0756^{* * *} \\
(0.0073)\end{array}$ & (2) & $\begin{array}{c}(1) \\
-0.132 * * * \\
(0.0041)\end{array}$ & 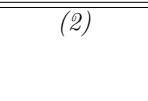 & $\begin{array}{c}(1) \\
-0.101^{* * *} \\
(0.0033)\end{array}$ & (2) \\
\hline Year $=2002$ & $\begin{array}{c}0.0223^{* * *} \\
(0.0005)\end{array}$ & $\begin{array}{c}0.0228^{* * *} \\
(0.0005)\end{array}$ & $\begin{array}{c}0.0430^{* * *} \\
(0.0004)\end{array}$ & $\begin{array}{c}0.0426^{* * *} \\
(0.0004)\end{array}$ & $\begin{array}{c}-0.135 \text { *** } \\
(0.0006)\end{array}$ & $\begin{array}{c}-0.134^{* * *} \\
(0.0007)\end{array}$ & $\begin{array}{c}-0.112^{\text {*** }} \\
(0.0007)\end{array}$ & $\begin{array}{c}-0.112^{* * *} \\
(0.0007)\end{array}$ \\
\hline EV $*$ Year $=2002[\mathrm{EV}(02)]$ & $\begin{array}{c}-0.0836^{* * *} \\
(0.0062)\end{array}$ & $\begin{array}{c}-0.0817^{* * *} \\
(0.0073)\end{array}$ & $\begin{array}{c}-0.0902^{* * *} \\
(0.0078)\end{array}$ & $\begin{array}{c}-0.100^{* * *} \\
(0.0093)\end{array}$ & $\begin{array}{c}0.131^{* * *} \\
(0.0042)\end{array}$ & $\begin{array}{c}0.120^{* * *} \\
(0.0048)\end{array}$ & $\begin{array}{c}0.102^{* * *} \\
(0.0037)\end{array}$ & $\begin{array}{c}0.0906^{* * *} \\
(0.0039)\end{array}$ \\
\hline Poor People (\%) & $\begin{array}{c}-0.00369 * * * \\
(0.0009)\end{array}$ & & $\begin{array}{c}-0.00608^{* * *} \\
(0.0007)\end{array}$ & & $\begin{array}{c}-0.0170^{* * *} \\
(0.0015)\end{array}$ & & $\begin{array}{c}-0.0184^{* * *} \\
(0.0015)\end{array}$ & \\
\hline $\begin{array}{l}\text { EV }(02)^{*} \text { Poor People }(\%) \\
\text { EV }^{*} \text { Poor People }(\%)\end{array}$ & $\begin{array}{c}-0.0113^{* * *} \\
(0.0043) \\
0.00153 \\
(0.0042)\end{array}$ & $\begin{array}{c}-0.00809 \\
(0.0049)\end{array}$ & $\begin{array}{c}-0.0302^{* * *} \\
(0.0058) \\
0.0236^{* * *} \\
(0.0058)\end{array}$ & $\begin{array}{c}-0.0264^{* * *} \\
(0.0060)\end{array}$ & $\begin{array}{c}-0.0268^{* * *} \\
(0.0029) \\
0.0298^{* * *} \\
(0.0033)\end{array}$ & $\begin{array}{c}-0.0258^{* * *} \\
(0.0033)\end{array}$ & $\begin{array}{c}-0.0306^{* * *} \\
(0.0029) \\
0.0341^{* * *} \\
(0.0030)\end{array}$ & $\begin{array}{c}-0.0276^{* * *} \\
(0.0031)\end{array}$ \\
\hline $\begin{array}{l}\text { Year }=2002 * \text { Poor People }(\%) \\
\text { Years of study }\end{array}$ & $\begin{array}{c}0.00869^{* * *} \\
(0.0011) \\
-0.00934^{* * *} \\
(0.0009)\end{array}$ & $\begin{array}{c}0.00725^{* * *} \\
(0.0011)\end{array}$ & $\begin{array}{c}0.0115^{* * *} \\
(0.0010) \\
0.00021 \\
(0.0008)\end{array}$ & $\begin{array}{c}0.0110^{* * *} \\
(0.0010)\end{array}$ & $\begin{array}{c}0.0271^{* * *} \\
(0.0015) \\
-0.00582^{* * *} \\
(0.0016)\end{array}$ & $\begin{array}{c}0.0248^{* * *} \\
(0.0015)\end{array}$ & $\begin{array}{c}0.0295^{* * *} \\
\quad(0.0016) \\
-0.0104^{* * *} \\
\quad(0.0016)\end{array}$ & $\begin{array}{c}0.0270^{* * *} \\
(0.0016)\end{array}$ \\
\hline $\begin{array}{l}\mathrm{EV}(02)^{*} \text { Years of study } \\
\mathrm{EV}^{*} \text { Years of study }\end{array}$ & $\begin{array}{c}0.0218^{* * *} \\
(0.0032) \\
-0.0142^{* * *} \\
(0.0031)\end{array}$ & $\begin{array}{c}0.0284^{* * *} \\
(0.0036)\end{array}$ & $\begin{array}{c}0.0223^{* * *} \\
(0.0049) \\
-0.0171^{* * *} \\
(0.0050)\end{array}$ & $\begin{array}{c}0.0189^{* * *} \\
(0.0052)\end{array}$ & $\begin{array}{c}-0.00985^{* * *} \\
(0.0026) \\
0.00932^{* * *} \\
(0.0030)\end{array}$ & $\begin{array}{c}-0.00832^{* * *} \\
(0.0030)\end{array}$ & $\begin{array}{c}-0.00955^{* * *} \\
(0.0025) \\
0.0131^{* * *} \\
(0.0026)\end{array}$ & $\begin{array}{c}-0.00917^{* * *} \\
(0.0028)\end{array}$ \\
\hline Year $=2002 *$ Years of study & $\begin{array}{c}-0.0152^{* * *} \\
(0.0013)\end{array}$ & $\begin{array}{c}-0.0154^{* * *} \\
(0.0013)\end{array}$ & $\begin{array}{c}-0.0231^{* * *} \\
(0.0011)\end{array}$ & $\begin{array}{c}-0.0231^{* * *} \\
(0.0011)\end{array}$ & $\begin{array}{c}0.0107^{* * *} \\
(0.0016)\end{array}$ & $\begin{array}{c}0.0104^{* * *} \\
(0.0016)\end{array}$ & $\begin{array}{c}0.0130^{* * *} \\
(0.0016)\end{array}$ & $\begin{array}{c}0.0129 * * * \\
(0.0016)\end{array}$ \\
\hline Constant & $\begin{array}{c}0.0936^{* * *} \\
(0.0039)\end{array}$ & $\begin{array}{c}0.0682^{* * * *} \\
(0.0063)\end{array}$ & $\begin{array}{c}0.0678^{* * *} \\
(0.0030)\end{array}$ & $\begin{array}{c}0.0675^{* * *} \\
(0.0080)\end{array}$ & $\begin{array}{c}0.164^{* * *} \\
(0.0049)\end{array}$ & $\begin{array}{c}0.119^{* * *} \\
(0.0071)\end{array}$ & $\begin{array}{c}0.126^{* * *} \\
(0.0030)\end{array}$ & $\begin{array}{c}0.108^{* * *} \\
(0.0072)\end{array}$ \\
\hline Observations & 10358 & $\begin{array}{r}10377 \\
\text { Robus } \\
* * * \\
\text { (1) Por }\end{array}$ & $\begin{array}{l}10358 \\
\text { andard er } \\
0.01, * *\end{array}$ & $\begin{array}{l}10377 \\
\text { in pare } \\
05, * p \\
\text { 2) Fixed }\end{array}$ & $\begin{array}{l}10358 \\
\text { ses }\end{array}$ & 10377 & 10358 & 10377 \\
\hline
\end{tabular}

Using average years of schooling, percentage of poor people, longevity HDI, inequality (Theil Index), children mortality, house infrastructure (telephone and electricity), percentage of woman, mayor party, mayor vote share on the last election, number of electors (as deviation from the threshold), state/municipality fixed effects, electors age composition (young and elderly), political engagement as controls 
Table 85: Placebo (2002) - Electronic voting impact on Turnout

\begin{tabular}{|c|c|c|}
\hline \multicolumn{3}{|l|}{ Dep. Var.: Turnout } \\
\hline Regressions & 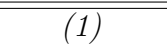 & 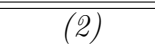 \\
\hline Electronic Voting (EV) & $\begin{array}{c}-0.0105 \\
(0.0083)\end{array}$ & \\
\hline Year $=2002$ & $\begin{array}{c}-0.0838^{* * *} \\
(0.0008)\end{array}$ & $\begin{array}{c}-0.0813^{* * *} \\
(0.0007)\end{array}$ \\
\hline$E V *$ Year $=2002[E V(02)]$ & $\begin{array}{c}0.0481^{* * *} \\
(0.0085)\end{array}$ & $\begin{array}{c}0.0355 * * * \\
(0.0080)\end{array}$ \\
\hline Poor People (\%) & $\begin{array}{c}-0.0331^{* * *} \\
(0.0025)\end{array}$ & \\
\hline EV $(02) *$ Poor People $(\%)$ & $\begin{array}{c}0.0138^{* *} \\
(0.0060)\end{array}$ & $\begin{array}{c}0.0179 * * * \\
(0.0053)\end{array}$ \\
\hline EV*Poor People $(\%)$ & $\begin{array}{c}0.000481 \\
(0.0064)\end{array}$ & \\
\hline Year $=2002 *$ Poor People $(\%)$ & $\begin{array}{c}0.0197^{* * *} \\
(0.0019)\end{array}$ & $\begin{array}{c}0.0119 * * * \\
(0.0017)\end{array}$ \\
\hline Years of study & $\begin{array}{c}0.0261^{* * *} \\
(0.0026)\end{array}$ & \\
\hline $\mathrm{EV}(02)^{*}$ Years of study & $\begin{array}{c}0.000891 \\
(0.0060)\end{array}$ & $\begin{array}{c}0.00987 \\
(0.0066)\end{array}$ \\
\hline $\mathrm{EV}^{*}$ Years of study & $\begin{array}{c}0.0126^{*} \\
(0.0067)\end{array}$ & \\
\hline Year $=2002^{*}$ Years of study & $\begin{array}{c}0.0195^{* * *} \\
(0.0021)\end{array}$ & $\begin{array}{c}0.0270^{* * *} \\
(0.0018)\end{array}$ \\
\hline Constant & $\begin{array}{c}0.764^{* * *} \\
(0.0112)\end{array}$ & $\begin{array}{c}0.686^{* * *} \\
(0.0114)\end{array}$ \\
\hline Observations & 10358 & 10377 \\
\hline
\end{tabular}

(1) Pooled regression; (2) Fixed Effects

Using average years of schooling, percentage of poor people, longevity HDI, inequality (Theil Index), children mortality, house infrastructure (telephone and electricity), percentage of woman, mayor party,mayor vote share on the last election, number of electors (as deviation from the threshold), state/municipality fixed effects, electors age composition (young and elderly), political engagement as controls 
Table 86: Placebo (2002) - Electronic voting impact on Party Votes

\begin{tabular}{|c|c|c|c|c|}
\hline \multirow{2}{*}{$\begin{array}{l}\text { Dep. Var.: Party Vote } \\
\text { Regressions }\end{array}$} & \multicolumn{2}{|c|}{ Federal Deputy } & \multicolumn{2}{|c|}{ State Deputy } \\
\hline & (1) & (2) & (1) & (2) \\
\hline Electronic Voting (EV) & $\begin{array}{c}0.113^{* * *} \\
(0.0080)\end{array}$ & & $\begin{array}{c}0.161^{* * *} \\
(0.0063)\end{array}$ & \\
\hline Year $=2002$ & $\begin{array}{c}0.0567^{* * * *} \\
(0.0005)\end{array}$ & $\begin{array}{c}0.0571^{* * * *} \\
(0.0005)\end{array}$ & $\begin{array}{c}0.113^{* * *} \\
(0.0005)\end{array}$ & $\begin{array}{c}0.113^{* * *} \\
(0.0005)\end{array}$ \\
\hline $\mathrm{EV}^{*}$ Year $=2002[\mathrm{EV}(02)]$ & $\begin{array}{c}-0.128^{* * *} \\
(0.0090)\end{array}$ & $\begin{array}{c}-0.106^{* * *} \\
(0.0105)\end{array}$ & $\begin{array}{c}-0.188^{* * *} \\
(0.0073)\end{array}$ & $\begin{array}{c}-0.162^{* * *} \\
(0.0081)\end{array}$ \\
\hline Poor People (\%) & $\begin{array}{c}-0.00598^{* * *} \\
(0.0011)\end{array}$ & & $\begin{array}{c}-0.000761 \\
(0.0009)\end{array}$ & \\
\hline EV $(02)^{*}$ Poor People $(\%)$ & $\begin{array}{c}-0.00112 \\
(0.0064)\end{array}$ & $\begin{array}{c}-0.00112 \\
(0.0061)\end{array}$ & $\begin{array}{c}0.0116^{* *} \\
(0.0051)\end{array}$ & $\begin{array}{c}0.0118^{* *} \\
(0.0048)\end{array}$ \\
\hline EV*Poor People (\%) & $\begin{array}{c}0.000443 \\
(0.0068)\end{array}$ & & $\begin{array}{c}-0.0116^{* *} \\
(0.0058)\end{array}$ & \\
\hline Year $=2002 *$ Poor People $(\%)$ & $\begin{array}{c}0.00878^{* * *} \\
(0.0012)\end{array}$ & $\begin{array}{c}0.00803^{* * *} \\
(0.0012)\end{array}$ & $\begin{array}{c}0.00119 \\
(0.0012)\end{array}$ & $\begin{array}{c}0.000796 \\
(0.0012)\end{array}$ \\
\hline Years of study & $\begin{array}{c}0.00237^{* *} \\
(0.0011)\end{array}$ & & $\begin{array}{c}0.00311^{* * *} \\
(0.0010)\end{array}$ & \\
\hline $\mathrm{EV}(02)^{*}$ Years of study & $\begin{array}{c}0.0282^{* * * *} \\
(0.0052)\end{array}$ & $\begin{array}{c}0.0313^{* * * *} \\
(0.0051)\end{array}$ & $\begin{array}{c}0.0418^{* * *} \\
(0.0043)\end{array}$ & $\begin{array}{c}0.0431^{* * *} \\
(0.0043)\end{array}$ \\
\hline $\mathrm{EV}^{*}$ Years of study & $\begin{array}{c}-0.0252^{* * *} \\
(0.0057)\end{array}$ & & $\begin{array}{c}-0.0355^{* * *} \\
(0.0050)\end{array}$ & \\
\hline Year $=2002^{*}$ Years of study & $\begin{array}{c}-0.0179 * * * \\
(0.0012)\end{array}$ & $\begin{array}{c}-0.0175^{* * *} \\
(0.0012)\end{array}$ & $\begin{array}{c}-0.0281^{* * *} \\
(0.0012)\end{array}$ & $\begin{array}{c}-0.0274^{* * *} \\
(0.0013)\end{array}$ \\
\hline Constant & $\begin{array}{c}0.0607^{* * * *} \\
(0.0032)\end{array}$ & $\begin{array}{c}0.0331^{* * * *} \\
(0.0067)\end{array}$ & $\begin{array}{c}0.0345^{* * *} \\
(0.0035)\end{array}$ & $\begin{array}{c}0.0321^{* * *} \\
(0.0063)\end{array}$ \\
\hline $\begin{array}{r}\text { Robus } \\
* * * \\
\text { (1) Poc }\end{array}$ & $\begin{array}{l}10358 \\
\text { andard erro } \\
0.01, * * \mathrm{p}< \\
\text { regression; }\end{array}$ & $\begin{array}{c}10377 \\
\text { in parent } \\
05, * \mathrm{p}<0 \\
\text { 2) Fixed } \mathrm{E}\end{array}$ & $\begin{array}{l}10358 \\
\text { ts }\end{array}$ & 10377 \\
\hline
\end{tabular}

Using average years of schooling, percentage of poor people, longevity HDI, inequality (Theil Index), children mortality, house infrastructure (telephone and electricity), percentage of woman, mayor party, mayor vote share on the last election, number of electors (as deviation from the threshold), state/municipality fixed effects,electors age composition (young and elderly), political engagement as controls 
Table 87: Placebo (2002) - Electronic voting impact on Party Fractionalization

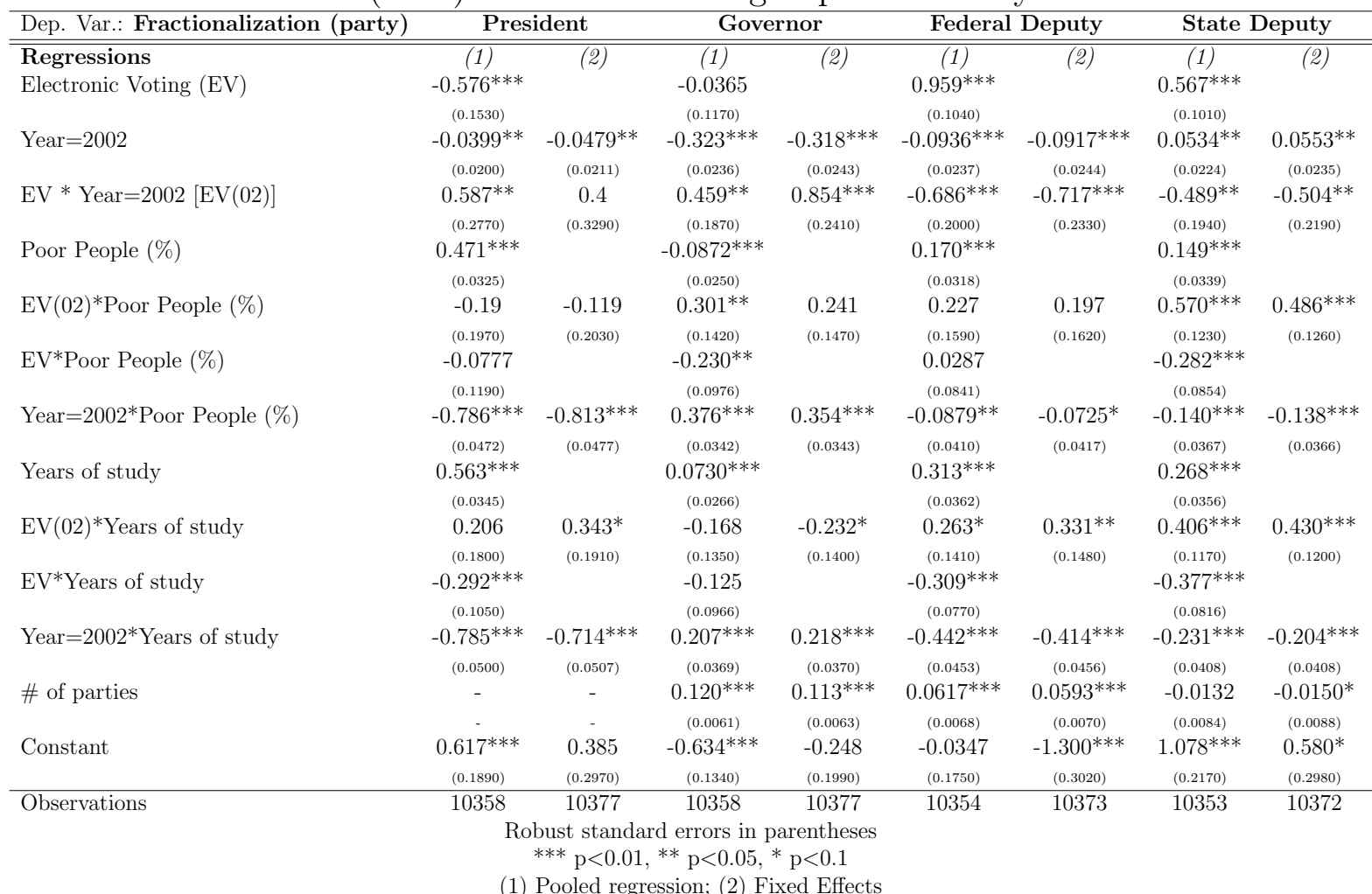

Using average years of schooling, percentage of poor people, longevity HDI, inequality (Theil Index), children mortality, house infrastructure (telephone and electricity), percentage of woman, mayor party,mayor vote share on the last election, number of electors (as deviation from the threshold), state/municipality fixed effects,electors age composition (young and elderly), political engagement as controls 
Table 88: Placebo (2002) - Electronic voting impact on Candidate Fractionalization

\begin{tabular}{|c|c|c|c|c|}
\hline \multirow{2}{*}{$\begin{array}{l}\text { Dep. Var.: Fractionalization (cand.) } \\
\text { Regressions }\end{array}$} & \multicolumn{2}{|c|}{ Federal Deputy } & \multicolumn{2}{|c|}{ State Deputy } \\
\hline & (1) & (2) & (1) & (2) \\
\hline Electronic Voting (EV) & 0.305 & & $-0.250^{*}$ & \\
\hline & $(0.2090)$ & & $(0.1370)$ & \\
\hline Year $=2002$ & $-0.0624^{* * *}$ & $-0.0923^{* * *}$ & $0.0609^{* * *}$ & $0.0510^{* * *}$ \\
\hline & $(0.0232)$ & $(0.0230)$ & $(0.0159)$ & $(0.0156)$ \\
\hline $\mathrm{EV} *$ Year $=2002[\mathrm{EV}(02)]$ & -0.365 & -0.196 & $0.322^{*}$ & 0.295 \\
\hline & $(0.2340)$ & $(0.2510)$ & $(0.1860)$ & $(0.2010)$ \\
\hline Poor People (\%) & $\begin{array}{c}0.183^{* * *} \\
(0.0349)\end{array}$ & & $0.222^{* * *}$ & \\
\hline EV $(02) *$ Poor People (\%) & -0.049 & -0.105 & 0.138 & 0.15 \\
\hline & $(0.1560)$ & $(0.1430)$ & $(0.1180)$ & $(0.1200)$ \\
\hline EV*Poor People (\%) & $0.372^{* *}$ & & $0.315^{* * *}$ & \\
\hline & $(0.1590)$ & & $(0.1170)$ & \\
\hline Year $=2002^{*}$ Poor People $(\%)$ & -0.0166 & -0.0218 & $-0.134^{* * *}$ & $-0.135^{* * *}$ \\
\hline & $(0.0300)$ & $(0.0289)$ & $(0.0332)$ & $(0.0323)$ \\
\hline Years of study & $\begin{array}{c}0.399^{* * *} \\
(0.0356)\end{array}$ & & $\begin{array}{c}0.264^{* * *} \\
(0.0384)\end{array}$ & \\
\hline EV $(02)^{*}$ Years of study & -0.119 & -0.175 & -0.153 & $-0.198^{*}$ \\
\hline & $(0.1460)$ & $(0.1610)$ & $(0.1080)$ & $(0.1150)$ \\
\hline EV*Years of study & -0.0346 & & $0.189^{*}$ & \\
\hline & $(0.1550)$ & & $(0.0996)$ & \\
\hline Year $=2002 *$ Years of study & $\begin{array}{c}-0.0760 * * \\
(0.0329)\end{array}$ & $\begin{array}{c}-0.0576^{*} \\
(0.0317)\end{array}$ & $\begin{array}{c}-0.0698^{* *} \\
(0.0345)\end{array}$ & $\begin{array}{c}-0.0546^{*} \\
(0.0329)\end{array}$ \\
\hline \# of candidates & $0.00204^{* * *}$ & $0.00260^{* * *}$ & $-0.00121^{* * *}$ & $-0.00115^{* * *}$ \\
\hline & $\begin{array}{l}(0.0006) \\
104 * * *\end{array}$ & $\begin{array}{r}(0.0006) \\
-0.258\end{array}$ & $\begin{array}{l}(0.0002) \\
1680 * * *\end{array}$ & $0.0002)$ \\
\hline Constant & $1.194^{* * *}$ & -0.258 & $1.682^{* * *}$ & $0.817^{* * *}$ \\
\hline Observations & $\begin{array}{l}(0.1610) \\
10358\end{array}$ & $\begin{array}{l}(0.2250) \\
10377\end{array}$ & $\begin{array}{l}(0.1390) \\
10358\end{array}$ & $\begin{array}{l}(0.2020) \\
10377\end{array}$ \\
\hline
\end{tabular}

(1) Pooled regression; (2) Fixed Effects

Using average years of schooling, percentage of poor people, longevity HDI, inequality (Theil Index), children mortality, house infrastructure (telephone and electricity), percentage of woman, mayor party, mayor vote share on the last election, number of electors (as deviation from the threshold), state/municipality fixed effects,electors age composition (young and elderly), political engagement as controls

Table 89: Placebo (2002) - Electronic voting impact on the "first" vote

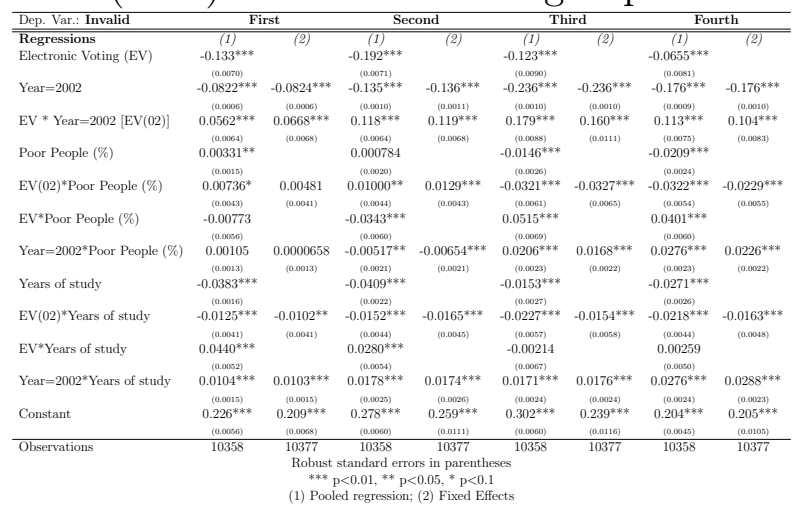

Using average years of schooling, percentage of poor people, longevity HDI, inequality (Theil Index), children mortality, house infrastructure (telephone and electricity), percentage of woman, mayor party, mayor vote share on the last election, number of electors (as deviation from the threshold), state/municipality fixed effects, electors age composition (young and elderly), political engagement as controls 
Table 90: Placebo (2002) - Electronic voting impact on Party Code Votes from the Mayor Party (over total party code votes)

\begin{tabular}{|c|c|c|c|c|}
\hline Dep. Var.: Mayor Party Code V. S. & \multicolumn{2}{|c|}{ Federal Deputy } & \multicolumn{2}{|c|}{ State Deputy } \\
\hline Regressions & (1) & (2) & $\overline{(1)}$ & $(2)$ \\
\hline Electronic Voting (EV) & $\begin{array}{c}-0.0411^{* *} \\
(0.0171)\end{array}$ & & $\begin{array}{c}-0.00611 \\
(0.0171)\end{array}$ & \\
\hline Year $=2002$ & $\begin{array}{c}-0.0677^{* * *} \\
(0.0025)\end{array}$ & $\begin{array}{c}-0.0680^{* * *} \\
(0.0027)\end{array}$ & $\begin{array}{c}-0.0391 * * * \\
(0.0024)\end{array}$ & $\begin{array}{c}-0.0381^{* * *} \\
(0.0025)\end{array}$ \\
\hline $\mathrm{EV}^{*} \mathrm{Year}=2002[\mathrm{EV}(02)]$ & $\begin{array}{c}0.0431^{*} \\
(0.0236)\end{array}$ & $\begin{array}{c}0.0781^{* * *} * \\
(0.0289)\end{array}$ & $\begin{array}{l}0.0164 \\
(0.0291)\end{array}$ & $\begin{array}{c}0.0337 \\
(0.0345)\end{array}$ \\
\hline Poor People (\%) & $\begin{array}{c}0.00173 \\
(0.0056)\end{array}$ & & $\begin{array}{c}0.00325 \\
(0.0054)\end{array}$ & \\
\hline EV $(02) *$ Poor People $(\%)$ & $\begin{array}{c}-0.00283 \\
(0.0150)\end{array}$ & $\begin{array}{c}-0.00859 \\
(0.0153)\end{array}$ & $\begin{array}{c}-0.00941 \\
(0.0175)\end{array}$ & $\begin{array}{c}-0.00771 \\
(0.0182)\end{array}$ \\
\hline Years of study & $\begin{array}{c}-0.0255^{* * *} \\
(0.0058)\end{array}$ & & $\begin{array}{c}-0.0195^{* * *} \\
(0.0057)\end{array}$ & \\
\hline EV*Poor People (\%) & $\begin{array}{c}-0.0205 \\
(0.0133)\end{array}$ & & $\begin{array}{c}-0.0166 \\
(0.0140)\end{array}$ & \\
\hline Year $=2002 *$ Poor People $(\%)$ & $\begin{array}{c}0.00439 \\
(0.0056)\end{array}$ & $\begin{array}{c}0.0047 \\
(0.0058)\end{array}$ & $\begin{array}{c}-0.0041 \\
(0.0053)\end{array}$ & $\begin{array}{c}-0.00562 \\
(0.0054)\end{array}$ \\
\hline $\mathrm{EV}(02)^{*}$ Mayor $(\mathrm{PT}=1)$ & $\begin{array}{c}0.102^{* * * *} \\
(0.0198)\end{array}$ & $\begin{array}{c}0.0789^{* * *} \\
(0.0258)\end{array}$ & $\begin{array}{c}0.100^{* * *} \\
(0.0209)\end{array}$ & $\begin{array}{c}0.105^{* * *} \\
(0.0290)\end{array}$ \\
\hline $\mathrm{EV}(02) *$ Mayor $(\mathrm{PMDB}=1)$ & $\begin{array}{c}-0.0430^{* * *} \\
(0.0147)\end{array}$ & $\begin{array}{c}-0.0442^{*} \\
(0.0235)\end{array}$ & $\begin{array}{c}-0.0229 \\
(0.0190)\end{array}$ & $\begin{array}{c}-0.00852 \\
(0.0287)\end{array}$ \\
\hline $\mathrm{EV}(02) *$ Mayor $(\mathrm{PSDB}=1)$ & $\begin{array}{c}-0.0900^{* * *} \\
(0.0164)\end{array}$ & $\begin{array}{c}-0.117^{* * *} \\
(0.0247)\end{array}$ & $\begin{array}{c}-0.0560^{* * *} \\
(0.0200)\end{array}$ & $\begin{array}{c}-0.0625^{* *} \\
(0.0276)\end{array}$ \\
\hline Constant & $\begin{array}{c}0.107^{* * *} \\
(0.0184)\end{array}$ & $\begin{array}{c}0.136^{* * *} \\
(0.0258)\end{array}$ & $\begin{array}{c}0.123^{* * *} \\
(0.0240)\end{array}$ & $\begin{array}{c}0.139 * * * \\
(0.0282)\end{array}$ \\
\hline servation & 9784 & 9803 & 9791 & 9810 \\
\hline
\end{tabular}

Robust standard errors in parentheses $* * * \mathrm{p}<0.01, * * \mathrm{p}<0.05,{ }^{*} \mathrm{p}<0.1$

(1) Pooled regression; (2) Fixed Effects

Using average years of schooling, percentage of poor people, longevity HDI, inequality (Theil Index), children mortality, house infrastructure (telephone and electricity), percentage of woman, mayor party, mayor vote share on the last election, number of electors (as deviation from the threshold), state/municipality fixed effects,electors age composition (young and elderly), political 